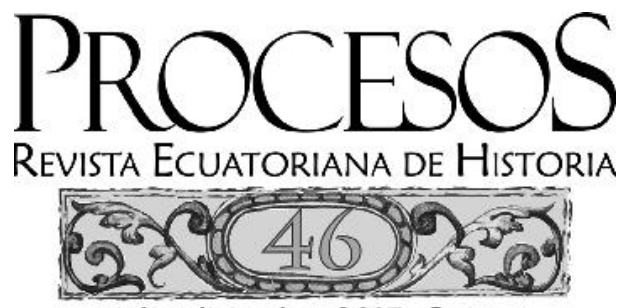

julio-diciembre 2017, Quito

ISSN: 1390-0099 e-ISSN: 2588-0780

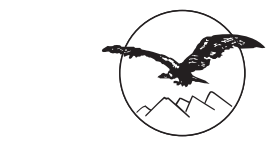

UNIVERSIDAD ANDINA

SIMÓN BOLÍVAR

Ecuador

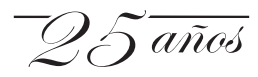

Área de Historia

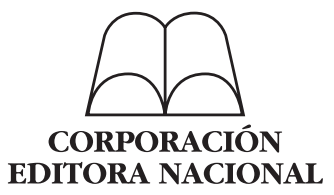


Índices académicos y bases de datos en los que consta Procesos:

\section{Hapi Online}

Hispanic American Periodical Index, Base DE DATOS DE LA UNIVERSIDAD DE CAlifornia, UCLA, Los Ángeles

\section{- Dialnet}

Sistema de Alertas de la UNIVERSIDAD DE LA RIOJA. EsPAÑA

\section{cibera}

Catálogo del Instituto IBEROAMERICANO DE BERLÍN

\section{LatAm \\ Estudios+}

ESTUDIOS LATINOAMERICANOS

(EsTADOS UnIDOS)

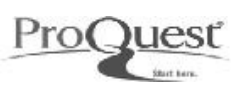

Prisma, Publicaciones Y REVISTAS SOCIALES Y HuMANísTicas

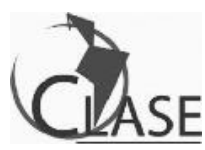

Citas Latinoamericanas EN Ciencias Sociales y Humanidades

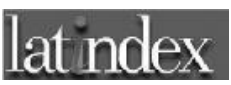

Sistema Regional DE INFORMACIÓN EN LÍNEA PARA REVISTAS CIENTÍFICAS de América Latina, el Caribe, ESPAÑA Y PORTUGAL

\section{LATINOAMERICANA}

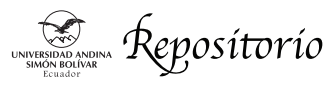

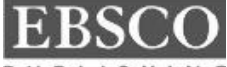

PUB L IS H I N G

Historical ABSTRACTS

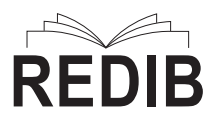

Red Iberoamericana

de Innovación y Conocimiento Científico

\section{REBIUN}

Red de Bibliotecas UNIVERSITARIAS DE ESPAÑA

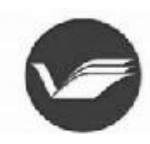

Biblioteca Virtual Miguel de Cervantes

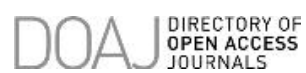




\section{PROCESOS}

\section{CONTENIDO}

\section{ESTUDIOS}

Gobierno y administración de la cárcel de Santafé de Bogotá, 1772-1800, por Juan Sebastián Ariza Martínez

El fomento a la educación básica en el Distrito del Sur en tiempos de la República de la Gran Colombia, por Roger Pita Pico

La Acción Católica en Cuenca: De las asociaciones obreras a la "ciudadanía moral" en el primer tercio del siglo XX, por Juan Martínez Borrero

La militancia política femenina en la izquierda marxista ecuatoriana de la década de los sesenta:

La URME y el PCE, por Tatiana Salazar Cortez

\section{DEBATES}

La política plebeya en las parroquias rurales de Cuenca, 1995-2005, por Mónica Mancero Acosta ................. 121

\section{SOLO LIBROS/reseñas}

Andrea Castagnola y Saúl López, editores, JUDICIAL Politics in Mexico: The Supreme Court and the Transition to Democracy, por Adrián R. López Andrade 
Ahmed I. Deidán de la Torre, Pueblos y soberanía, CONTINUIDADES Y RUPTURAS CONCEPTUALES DURANTE LA INSURGENCIA EN EL REINO DE QUITO (1809-1813), por Milagros Villarreal 159

SOLO LIBROS/referencias ............................................. 163

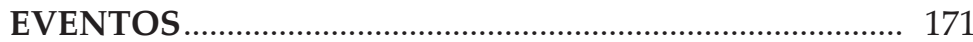

Árbitros de este número .................................................... 181

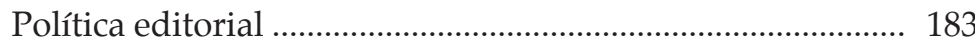




\section{PROCESOS \\ ReVISTA ECUATORIANA DE HISTORIA}

\section{Contents}

\section{STUDIES}

Prison governance and administration

in Santafé de Bogotá, 1772-1800, by Juan Sebastián Ariza Martínez ................................................ 9

Promoting basic education in the Southern District at the time of the Republic of Gran Colombia, by Roger Pita Pico

Catholic Action in Cuenca: From workers associations to "moral citizenry" in the first third of the twentieth century, by Juan Martinez Borrero

Women's political activism in Ecuador's

Marxist leftwing parties in the sixties:

The URME and the PCE, by Tatiana Salazar Cortez

\section{DEBATES}

Peasant politics in the rural parishes de Cuenca, 1995-2005, by Mónica Mancero Acosta

\section{ONLY BOOKS/reviews}

Andrea Castagnola and Saúl López, editors, JUDICIAL Politics in Mexico: The Supreme Court and the Transition to DeMOCRACY, by Adrián R. López Andrade 
Ahmed I. Deidán de la Torre, Pueblos y soberanía, CONTINUIDADES Y RUPTURAS CONCEPTUALES DURANTE LA INSURGENCIA EN EL REINO DE QUITO (1809-1813), by Milagros Villarreal 159

ONLY BOOKS/references .............................................. 163

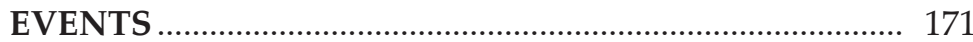

Peer reviewers for this edition .......................................... 181

Editorial Policies _............................................................... 183 
Estudios 



\title{
Gobierno y administración de la cárcel de Santafé de Bogotá, 1772-1800
}

\author{
Prison governance and administration \\ in Santafé de Bogotá, 1772-1800
}

Juan Sebastián Ariza Martínez

Universidad del Rosario (Bogotá, Colombia) juan.ariza06@gmail.com

DOI: http:/ / dx.doi.org/10.29078/rp.v0i46.647

Fecha de presentación: 24 de julio de 2017

Fecha de aceptación: 24 de agosto de 2017

Artículo de investigación 
RESUMEN

A partir de varios estudios de caso, este artículo da cuenta de las principales dificultades que encontraron los alcaides para gobernar la real cárcel de corte de Santafé y la forma cómo algunos reos, lograron escapar del encierro y retaron a las autoridades. A fines del siglo XVIII la cárcel estaba encargada del control y prevención de actos delictuosos en la ciudad. Sin embargo, en la práctica, la institución era mal administrada, había fugas constantes y los cuerpos legales provenientes desde la península eran escasamente aplicados.

Palabras clave: historia de América Latina, historia colonial, historia social, administración de justicia, alcaide, fugas, real cárcel, Santafé, siglo XVIII.

ABSTRACT

Based on various case studies, this article describes the main difficulties that prison wardens encountered when governing the royal prison of the court Santafé and how certain inmates were able to break out of jail and challenge the authorities. At the end of the

eighteenth century, the prison was in charge of controlling and preventing crime in the city. Nevertheless, in practice, the institution

was poorly administered, there were constant jailbreaks, and laws from the peninsula were scarcely enforced.

Keywords: History of Latin America, colonial history, social history, administration of justice, prison warden, jailbreaks, royal prison, Santafé, eighteenth century.

Juan Sebastián Ariza Martínez

Magíster en Historia por la Universidad Andina Simón Bolívar, Sede Ecuador y licenciado en la misma área por la Universidad del Rosario, con mención en Antropología. Docente en la Universidad del Rosario. Entre sus temas de investigación sobresalen la historia social y judicial en el período colonial, así como la historia de la ciencia y la medicina. Entre sus publicaciones están: La cocina de los venenos. Aspectos de la criminalidad en el Nuevo Reino de Granada, siglos XVII y XVIII (2015) y “¿Remedios o ponzoñas?

Aproximación al uso de la yerbatería como método curativo en el Nuevo Reino de Granada durante el siglo XVIII", publicado en el Anuario de Historia Regional y de las Fronteras (2014). 


\section{INTRODUCCIÓN}

A fines del siglo XVIII se presentaron algunos delitos de fuga de la Real Cárcel de Corte de Santafé, que dan luces sobre el funcionamiento de la institución entre 1772 y 1800. Esta institución, presente en la mayoría de poblaciones del virreinato, era administrada por un alcaide o carcelero mayor, que se encargaba de su correcto funcionamiento y de llevar registro de los sucesos que tenían lugar dentro de ella.

El objetivo de esta investigación es aproximarse a la organización del gobierno de la cárcel de corte de Santafé y conocer las leyes que allí operaban, para así determinar si se seguían o no al pie de la letra. Estas líneas parten de dos cuestionamientos principales: cuán laxo era el gobierno de la cárcel y cuán fácil podían fugarse los presos de ella. Estas preguntas permiten aproximarse a las características de funcionamiento y ordenamiento de la real cárcel de corte de Santafé y la forma cómo los presos, a través de sus actuaciones, intentaban retar el orden preestablecido que en teoría, imperaba dentro de la cárcel.

La investigación sugiere que, a pesar de existir corpus legales que determinaban el ordenamiento de la institución, estos no se seguían de forma estricta, sino que, por el contrario, los gobernantes de la institución leían las leyes y las interpretaban o apropiaban de ellas, dependiendo de los intereses que, desde su perspectiva, debían primar en la cárcel de Santafé.

\section{EL GOBIERNO}

\section{Y LA ADMINISTRACIÓN CARCELARIA}

Santafé colonial contaba con tres espacios para la custodia y retención de quienes habían sido acusados de criminales: la cárcel de corte, ubicada en el costado sur de la plaza mayor de la ciudad; la cárcel chica, que se encargaba de los casos de crímenes menores y dependía del cabildo de la ciudad; y el Divorcio, que hacía las veces de cárcel para mujeres y casa de expósitos. Para efectos de esta investigación, únicamente se tendrá en cuenta la primera. Todas ellas se guiaban bajo los preceptos de diferentes normas, entre las cuales, sobresalen las Leyes de Indias, Las Siete Partidas y la Novísima recopilación de las leyes de España, en las cuales es posible identificar secciones dedicadas a la organización, distribución y personal de la real cárcel.

Estas leyes establecían la importancia de que en las ciudades y villas que conformaran la Real Audiencia hubiera una cárcel destinada a la guardia y custodia de los delincuentes y otros, que aunque no se especifica quiénes son, 
pero que gracias a las visitas de la cárcel se puede identificar que se trata de personas a quienes se les acusa de tener comportamientos inadecuados o que afectaban la moral cristiana. ${ }^{1}$ Entre los reos, también había esclavos que se habían manifestado en contra de sus amos, artesanos que no cumplían con las obras que se les habían encargado, vagos y borrachos que se recogían durante las rondas nocturnas y en general, "todos aquellos contraventores de los autos del buen gobierno" de la ciudad. ${ }^{2}$ La forma en que debía ser gobernada y las autoridades encargadas de ello estaban también reglamentadas.

\section{El alcaide de cárcel}

Las Leyes de Indias señalaban que toda cárcel debía tener un alcaide o carcelero mayor, encargado de gobernar la institución y garantizar la guardia y custodia de los presos que entraran en ella. También debía velar por el buen trato hacia los reos y asegurarse de que el recinto permaneciera limpio y ordenado. ${ }^{3}$ Además, las leyes establecían que era necesario que el carcelero mayor residiera en el presidio o la cárcel y, en caso de no cumplir con ello, debía pagar una multa de 70 pesos. ${ }^{4}$ También estaba encargado de organizar y llevar a cabo vigilias periódicas, en las noches si era necesario, no solo para verificar el estado de las puertas y cerraduras de los calabozos, sino también para comprobar que

1. Recopilación de las Leyes de los Reinos de las Indias, lib. 7, tít. 6, ley I (Madrid: Antonio Pérez de Soto, 1774 [1680]); Las Siete Partidas del sabio rey don Alfonso Nono [1265], Partida VII, tít. 29, [¿ed. por?] Juan Brocar (1542); Novísima recopilación de las Leyes de España, lib. 7, tít. 2, ley 2 (París: Librería de don Vicente Salvá, 1846); Archivo General de la Nación (AGN), "Actas de visitas de cárcel practicadas por el virrey y los oidores", Sección Colonia, fondo Policía, t. 3, doc. 15, ff. 477r-507v; ibíd., "Diligencias de visitas de cárcel practicadas por la Real Audiencia”, fondo Archivos, t. 8, doc. 2, ff. 3r-381v; ibíd., "Actas de visita de cárcel. Enumeración de los reos y sus causas", fondo Criminales (Juicios), t. 95, doc. 20, ff. 828r-835v; ibíd., "Actas de visita de cárcel", fondo Archivos, t. 3, doc. 28, ff. 770r, 181r; ibíd., "Visitas de cárcel realizadas por los miembros de la Real Audiencia de Santafé", fondo Real Audiencia-Cundinamarca, t. 11, doc. 5, ff. 242r-250v.

2. María Antonieta Vásquez Hahn, "Para la 'felicidad pública'. El barón de Carondelet y el establecimiento del presidio urbano de Quito". En Carondelet: Una autoridad colonial al servicio de Quito (Quito: Fonsal, 2007), 245.

3. Las visitas de cárcel se hacían semanalmente por parte de los oficiales de la Real Audiencia, acompañados del alcaide de cárcel. En ella daban cuenta de las irregularidades que fueran identificadas en la cárcel, el número de reos que permanecían bajo custodia y que el alguacil mayor revisaba junto con las peticiones que se hacían en las visitas. Novísima recopilación de las Leyes de España, lib. 12, tít. 32, ley 2; Tamar Herzog, "El rescate de una fuente histórica: los libros de visita de cárcel (El caso de Quito, 1738-1750)", Anuario de Estudios Americanos 52, n. ${ }^{\circ} 2$ (1995): 251-261.

4. Recopilación de las Leyes de los Reinos de las Indias, lib. 7, tít. 6, ley VII, VIII y IX; Novísima recopilación de las Leyes de España, lib. 12, tít. 38, leyes IV y XXV; Diccionario de la Real Academia Española de la Lengua, t. 1, http: / / web.frl.es/DA.html. 
tanto los presos como el personal de la cárcel ocuparan su lugar, lo que suponía que ellos mismos debían guardar las llaves de la cárcel en todo momento. ${ }^{5}$

La elección de un alcaide estaba regida por preceptos y órdenes que provenían desde España. Para obtener el cargo era necesario contar con bienes materiales que permitieran pagar una fianza, o buscar a alguien que respaldara su costo. Quien aspiraba al cargo debía ser reconocido públicamente por su buena fama y moralidad, lo que implicaba que nunca hubiera sido procesado por ningún delito. Además, quienes se postularan debían ser mayores de 35 años, estar casados, saber leer, escribir y llevar cuentas, con el fin de completar la información de los libros de cárcel. ${ }^{6}$

La determinación de quién ocupaba el oficio estaba en manos del rey y su consejo de gobierno, quienes, después de oír las evaluaciones de las autoridades locales, elegían al alcaide. ${ }^{7}$ Salir favorecido con este cargo, era un logro de la vida de los aspirantes, pues la cárcel se consideraba un bien público y, como tal, el título debía cuidarse y ejercerse de la mejor manera posible con el fin de obtener reconocimiento social. ${ }^{8}$

Muchos de los alcaides muestran en sus oficios que el presupuesto que la Real Audiencia proveía para el funcionamiento de la cárcel no era suficiente, pues el monto asignado debía repartirse entre las mejoras de la casa donde funcionaba la cárcel, la manutención de los presos pobres y el salario de los guardias y oficiales de la institución, lo que hacía que el dinero escaseara y no pudiera cubrir todos los rubros que debía. ${ }^{9}$ Es importante tener en cuenta que no todo el dinero de la cárcel procedía de la Audiencia, en algunos casos, el sostenimiento de los presos se hacía a través de montos que provenían de la limosna y la caridad -principalmente en los casos de los presos pobres-, ${ }^{10}$ o de la confiscación de objetos que se hacía a los retenidos cuando tenían bienes propios y de gran valor. ${ }^{11}$

5. Recopilación de las Leyes de los Reinos de las Indias, lib. 7, tít. 6, ley XI; Las Siete Partidas..., Partida VII, tít. 29, ley VIII.

6. Joaquín Escriche, Diccionario razonado de Legislación y Jurisprudencia (París: Librería de la viuda de Boured, 1931 [1847]), 124-126.

7. Ibíd.

8. Aude Argouse, "Archivos de la vulnerabilidad. Reos en Santiago de Chile (16501780)", Clio y crimen, n. ${ }^{\circ} 12$ (2015): 199.

9. Valeria Sánchez Michel, Usos y funcionamientos de la cárcel novohispana. El caso de la Real Cárcel de Corte a finales del siglo XVIII (Ciudad de México: El Colegio de México, 2008), 66-71; Lucas Esteban Rebagliati, "Caridad y control social en el Buenos Aires virreinal: El caso de los Defensores de pobres (1776-1809)" (ponencia presentada en las Segundas Jornadas Nacionales de Historia Social. Córdoba, 2009), 10-17; Argouse, "Archivos de la vulnerabilidad...", 199.

10. Sánchez Michel, Usos y funcionamientos de la cárcel..., 66.

11. Beatriz Patiño Millán, Criminalidad, ley penal y estructura social en la provincia de Antioquia, 1750-1820 (Bogotá: Universidad del Rosario, 2013), 34-48. 
Durante el Antiguo Régimen, cumplir con los deberes religiosos y de caridad cristiana, se convirtió en uno de los temas más importantes de la sociedad. De ahí que las autoridades, como en el caso del virrey Manuel de Guirior, se preocuparan por cumplir con estos preceptos. En febrero de 1775, Guirior decretó que la producción que se sacara de las minas y manantiales salitrosos de Rute y la Calera -ubicadas dentro de las salinas de Zipaquirádebía comercializarse con el fin de obtener beneficios y repartirlos entre el hospicio y las cárceles de Santafé, "para los piadosos fines de la manutención de los pobres recogidos [...] y queriendo mi piedad aumentar cuanto pueda este ramo en beneficio de tan religioso fin".$^{12}$ Lo anterior, con el fin de garantizar que los gastos de la alimentación de los presos pobres y la manutención de los espacios de encierro, tuvieran un respaldo económico. ${ }^{13}$

Esta determinación tomada por Guirior estuvo vigente hasta entrado el siglo XIX. Sin embargo, la producción en las minas se vio estancada en algunos meses, debido a que los presos que trabajaban en ellas escapaban con frecuencia o no se lograba vender el producido, y lo que se recolectaba para la beneficencia de las cárceles era mínimo.

En algunas oportunidades, el oficio de alcaide no era bien remunerado. Algunos de ellos no solo estaban pendientes de mantener en orden la cárcel, sino que también debían velar por el buen trato y las condiciones de vida de los reos. Lo anterior exigía que el carcelero mayor destinara parte de su sueldo para la manutención y el amparo de los reos pobres. Aunque no se tiene certeza del monto que se le pagaba al alcaide en Santafé, se puede tener una idea a partir de los testimonios de la cárcel de Chile, en donde se estipulaba un salario de entre 150 y 200 pesos por año. ${ }^{14}$ Asimismo, se puede tomar como referencia el pago que recibían quienes trabajaban en el hospicio de

12. AGN, "Salinas de Zipaquirá. Remate de las de Rute y la Calera, verificado en Francisco González Manrique y cuyo producto se destina a los hospicios y cárceles de Santafé", Sección Colonia, fondo Policía, t. 1, doc. 1, ff. 5r-6v.

13. Existen varias reflexiones en torno a la pobreza y a quienes se consideraban pobres en el siglo XVIII. Dado que este debate excede los límites de la investigación, se entenderá como pobres a aquellas personas desamparadas que en ocasiones pasaban frío y hambre durante su permanencia en prisión, que carecían de propiedades y, por tanto, no tenían cómo costear su estancia en el encierro ni los trámites gubernamentales que esta implicaba. Respecto a la definición de pobreza y las quejas, véase Adriana María Alzate Echeverri, Geografía de la lamentación. Institución hospitalaria y sociedad, Nuevo Reino de Granada, 17601810 (Bogotá: Universidad del Rosario / Pontificia Universidad Javeriana, 2012), 6, 15-26; Pedro Carasa Soto, "Cambios en la tipología del pauperismo en el Antiguo Régimen", Investigaciones históricas: Época moderna y contemporánea, n. 7 (1987): 131-150; Norman Martín, "Pobres, mendigos y vagabundos en la Nueva España, 1702-1766: Antecedentes y soluciones presentadas", Estudios de Historia Novohispana 8 (1985): 99-126.

14. Argouse, "Archivos de la vulnerabilidad...", 199. 
Santafé; dependiendo del cargo que ocupaban eran remunerados así: 200 pesos anuales para el administrador del hospicio, el capellán del lugar y el mayordomo, 70 pesos para el médico de la casa y 60 pesos para el escribano. ${ }^{15}$ Lo que permite señalar que probablemente el sueldo del alcaide de la real cárcel oscilaba entre los 150 y 200 pesos anuales.

En un auto radicado por Francisco de los Reyes García puede estudiarse el compromiso que exigía el oficio de alcaide. En 1778, Francisco señaló a la Real Audiencia que desde hacía varios meses don Bernardo Ruiz de Noriega había internado en la cárcel de corte a ocho de sus esclavos y solo había destinado diecinueve pesos para la manutención de ellos. Ante tal situación, don Diego Tabares, gobernador de Santafé, le encargó al alcaide la manutención de los presos, pues según las Leyes de Indias esta era su obligación. ${ }^{16}$

Así, se puede señalar que el oficio del alcaide iba más allá de ser el administrador de la cárcel e implicaba una labor misericordiosa según la cual debía comprometerse a garantizar el bienestar de todos los reos -en especial de los pobres y desposeídos que no tenían cómo sustentar su estadía en la prisiónsin importar las consecuencias que acarreara la manutención de estos. ${ }^{17}$ Pero, al mismo tiempo, era una forma de caridad, un acuerdo tácito de ayuda a los pobres que se fundamentaba en las virtudes cristianas.

No se sabe con certeza si, además del puesto de alcaide, quienes ocupaban el cargo tenían otro tipo de ingresos o desarrollaban otras actividades. De ser así, esto les ayudaría a cubrir sus gastos personales. Además, vale la pena tener en cuenta que no siempre los alcaides actuaban de buena voluntad a través de obras de misericordia; podría pensarse que había quienes no les importaba el bienestar de los reos y por eso no hacían nada para paliar su sufrimiento; o simplemente actuaban de forma misericordiosa para lograr reconocimiento social.

Un caso similar al anterior, en el que se puede analizar la figura del alcaide como un oficial al servicio de la institución y de los presos, tuvo lugar en febrero de 1774, cuando, luego de dos años de asumir económicamente el costo de la luz y el pago de salarios de los guardias de la cárcel, el alcaide Antonio Mesa y el alguacil mayor deciden enviar un auto a la Real Audien-

15. Joaquín Durán y Díaz, Estado general de todo el Virreinato de Santafé de Bogotá. Edición facsimilar (Bogotá: Banco de la República, 2012 [1794]), 89.

16. AGN, "Diego Tabares, alcaide de la cárcel de Santafé, solicita el pago de lo que ha gastado en la manutención de ocho esclavos de don Bernardo Ruiz de Noriega", Sección Colonia, fondo Miscelánea, t. 114, doc. 32, f. 210r; Recopilación de las Leyes de los Reinos de las Indias, lib. 7, tít. 6, leyes IX, XIV, XVI y XVII.

17. La misericordia era entendida como una virtud inclinada al ánimo, que buscaba compadecerse de los trabajos o miserias de los demás. Real Academia de la Lengua, Diccionario de Autoridades (1734), t. 4, http:/ / web.frl.es/DA.html. 
cia para que desde allí asumieran el incremento de los costos de la cárcel. ${ }^{18}$

A pesar de la petición, el auto únicamente fue atendido en agosto de 1775, tiempo en el cual tanto el alcaide como el alguacil asumieron el costo de la luz con sus propios salarios. ${ }^{19}$ La Real Audiencia de Santafé, en medio de sus múltiples tareas, conocía varios litigios de tipo civil y criminal; sin embargo, la cantidad de denuncias que recibía a diario, por parte de los tribunales del virreinato y los habitantes del mismo, la extensión del territorio sobre el que debía gobernar, las funciones gubernativas y militares de las que debía encargarse, entre otras tareas, ${ }^{20}$ hacía que las peticiones se acumularan y no fuera posible dar respuesta de forma oportuna a todas ellas. De ahí que la solicitud de Mesa fuera atendida casi un año después de interponer el auto, lo que lo obligó a seguir pagando los costos de luz de la cárcel.

Mientras estuvo a cargo de la cárcel, Mesa también se preocupó por la manutención del lugar. En otro oficio, fechado en septiembre de 1775, se dirigió directamente al virrey Guirior y le solicitó que tuviera consideración de los gastos que había en la real cárcel y el poco dinero con que se contaba para ellos, pues, aunque anualmente las cajas reales destinaban diez pesos para comprar vino, pan y cera que se utilizaba en la misa de la capilla, ese año no lo habían hecho. ${ }^{21}$

Otro caso similar tiene lugar en 1784 cuando el alguacil mayor de la Audiencia, Francisco Javier de Laserna, recibió un oficio por parte del alcaide de la real cárcel en el que le solicitaba que proveyera a la capilla de ornamentos y otros objetos necesarios en las celebraciones religiosas, pues los que había allí se encontraban indecentes. ${ }^{22}$ Después de recibir notificación de lo sucedido, Laserna visitó la cárcel y en su reporte señaló que "he notado una suma indecencia porque [la capilla] carece de todo ornato y los ornamentos, cálices y vinagreras están del todo inservibles", por lo que consideró necesario que se renovaran estos objetos para que se pudiera continuar celebrando las misas en días festivo y administrando los sacramentos a los presos. ${ }^{23} \mathrm{En}$

18. AGN, "Mesa, Antonio. Alcaide de la cárcel de Santafé demanda se satisfaga el costo de la luz para la guardia que se erigió como mayor seguridad para la custodia de los reos", Sección Colonia, fondo Archivos, t. 1, doc. 203, ff. 867r-868 r.

19. Ibíd.

20. Julián Andrei Velasco Pedraza, Justicia para los vasallos de su majestad. Administración de justicia en la Villa de San Gil, siglo XVIII (Bogotá: Universidad del Rosario, 2015), 37.

21. AGN, "Mesa, Antonio. Alcaide de la cárcel de Santafé pide dinero para los oficios religiosos de la capilla", Sección Colonia, fondo Archivos, t. 1, doc. 216, f. 892r.

22. La indecencia hacía referencia a objetos indecorosos, no convenientes, en mal estado o viejos. Real Academia de la Lengua, Diccionario de Autoridades (1734).

23. AGN, "Laserna, Francisco Javier de. Alguacil mayor de la Real Audiencia solicita provisión de ornamentos para la capilla de la cárcel de corte", Sección Colonia, fondo Historia eclesiástica, t. 16, doc. 30, ff. 739r-v. Énfasis añadido. 
casos como el anterior, se determinaba que los objetos fueran traídos de otras capillas en donde sobraran o no hicieran falta, con el fin de repartirlos y dar cumplimiento a lo que señalaban las leyes.

\section{Riesgos y dificultades del oficio de carcelero mayor}

No todos los carceleros mayores se interesaron por desempeñar su oficio con excelencia, o por cumplir con los preceptos civiles y religiosos de la época. Lo anterior, podría anotarse, fue uno de los elementos que facilitó la fuga de algunos reos de la real cárcel de Santafé.

El 3 de noviembre de 1773 el presidente de la real cárcel de Santafé advirtió a los guardias de la ausencia de Ignacio Varela, sindicado de varios delitos. En su examinación por el presunto escalamiento del reo, el alcaide señaló que "la puerta interior del patio estaba cerrada, como también las ventanas, y que en el calabocito no dejó ropa ninguna el d[ic]ho Varela, sino que se llevó lo que tenía". ${ }^{24}$ Luego de recoger los testimonios iniciales y hacer el reconocimiento del lugar por parte de los guardias, se presumió que Varela se había fugado por las negligencias de trabajo de las que se acusó al alcaide Francisco Salgado.

La pesquisa realizada por el personal de la cárcel señaló que no se habían encontrado mayores alteraciones físicas en la cárcel salvo un par de tejas rotas y metidas para adentro en el patio que daba a la huerta de la Real Audiencia y un pedazo de pared descascarada. Aun así, las puertas y ventanas de la cárcel permanecieron cerradas hasta que el hermano del alcaide y oficial mayor de ella, Juan Ignacio Salgado, salió semidesnudo a abrir la puerta que del zaguán que conducía al patio principal, después de que les habían avisado que el preso no estaba. ${ }^{25} \mathrm{El}$ hecho de que Juan Ignacio tuviera las llaves y no Francisco, según los testimonios de varios de los presos, era costumbre desde que ocupó el puesto de oficial de la cárcel, lo que despertó las sospechas de varios de los guardias y de los visitadores de la Audiencia,

24. AGN, "Investigación sobre fuga de la cárcel de Santafé de Ignacio Varela, reo remitido de Cartago. Juicio seguido a Francisco Salgado, alcaide, por dicha evasión”, Sección Colonia, fondo Criminales (Juicios), t. 135, doc. 2, f. 218r. El presidente de la cárcel era uno de los reos que hacía las veces de intermediador entre los presos y las autoridades de la cárcel. El escalamiento hace referencia al uso de escaleras arrimándolas a murallas, ventanas techos, con el fin de entrar o salir de algún lugar. También se entiende como sinónimo de fuga de la cárcel. Real Academia de la Lengua, Diccionario de Autoridades (1732), t. 3, http: / / web.frl.es/DA.html.

25. AGN, "Investigación sobre fuga...", f. 219r y 224r. 
quienes abrieron un proceso en contra del alcaide por incumplir con su juramento de guardar las ordenanzas que regulaban su oficio. ${ }^{26}$

El comportamiento poco habitual de algunos alcaides, a veces flexible, relajado y con una precaria vigilancia por parte de sus superiores de la Audiencia, permite señalar que, durante el gobierno de algunos carceleros, la institución no era un lugar de estricta vigilancia y control para quienes permanecían en ella -tal como sucede en nuestros días-, sino que, por el contrario, era un espacio con pocas restricciones. Lo anterior también puede rastrearse en el proceso que se sigue en contra de Francisco Aldao y José Manuel Pérez Sotelo, quienes se fugaron de cárcel de Santafé en la noche del viernes 13 de junio de 1800 .

Una vez iniciada la indagatoria se evidenció que, por un lado, el alcaide don Francisco Barba se había ausentado de su cargo esa noche -por razones que se desconocen- y en su lugar había nombrado a un interino que, en compañía de la esposa de Barba, ejercería como carcelero mayor. El joven Juan Nepomuceno López, que trabajaba como oficial de la cárcel, estaba encargado de la administración del recinto la noche en que ocurrió el escalamiento. Sobre él y su oficio había varias querellas porque, quizás por su inexperiencia, no ejercía todas las funciones tal como lo hacía Barba y, por ejemplo, permitía que terceros entraran a la cárcel a sacar las posesiones que los presos tenían en sus calabozos, o "no rondaba ni celaba la cárcel, lo que si hacía don Francisco Barba los más de los días, registrando calabozos [y] tablados en cumplimiento de su obligación". ${ }^{27}$

Según las Leyes de Indias, quien asumía el oficio de alcaide debía residir en la cárcel y comprometerse a cumplir con sus funciones, bajo juramento "sobre la cruz y los santos evangelios en debida forma que bien, y fielmente guardaran los presos, leyes y ordenanzas que sobre esto disponen" ${ }^{28} \mathrm{Sin}$ embargo, no es posible conocer si, en calidad de interino, se exigió a López hacer este juramento. El caso de la fuga de Aldao indica que Juan Nepomuceno incurrió en algunas faltas, como el no dormir en la cárcel sino retirarse a su casa después de las cinco de la tarde, bajo el argumento de que esta quedaba sobre la calle del Divorcio, en la que también estaba ubicada la cárcel de corte; no realizar las rondas de vigilancia nocturna (la última la hizo antes

26. Cabe anotar que el carcelero podía compartir las llaves de la prisión con otros, con la excepción de que no lo hiciera con indios o negros. Al respecto ver Recopilación de las Leyes de los Reinos de las Indias, lib. 7, tít. 6, leyes V y VI.

27. AGN, "Diligencias sumarias practicadas en averiguación del escalamiento de la cárcel por los presos José Aldao y José Manuel Pérez Sotelo", Sección Colonia, fondo Criminales (Juicios), t. 12, doc. 7, ff. 511r, 515 r-516 r y 531 r.

28. Recopilación de las Leyes de los Reinos de las Indias, lib. 7, tít. 6, ley V. 
de irse a su casa el día de la fuga), ni verificar que todos los presos estuvieran en los calabozos en las noches. ${ }^{29}$

La cantidad de obligaciones que tenía el carcelero mayor y la dificultad de delegar sus tareas en otras personas, a pesar de contar con la ayuda de los baqueteros, lo llevó al incumplimiento de sus deberes. ${ }^{30}$ En el caso que se instauró contra Francisco Salgado por la fuga de Ignacio Varela, se estableció que, además de lo anterior, la ingenuidad de Salgado jugó un papel fundamental en el escalamiento. En la confesión que se le tomó, señaló que, a pesar de la advertencia de los visitadores de cárcel de que asegurara con cadenas a Varela por considerarse "muy peligroso", después de terminar el oficio se había negado a hacerlo por petición de la esposa del reo, que el día antes de la fuga había ido a su despacho en la cárcel y le había dicho que le llevaba:

Un recado de parte del s[eño]r oidor diciendo que omitiese echarle grillos a su marido y como esto fue en presencia del d[ic]ho Sánchez [un testigo que había ido a sacar de la cárcel a su esclavo] que no la contradijo, presumió el declarante que la referida orden no sería falsa, aunque reparo en que no venía por escrito como había venido otra para la soltura de un mulato Becerra. ${ }^{31}$

El uso de grilletes y cadenas fue una práctica común durante el período de estudio, para garantizar que los reos no escaparan. ${ }^{32}$ Sin embargo, en algunas

29. En el documento se especifica que, a diferencia de los otros reos, Aldao y Pérez Sotelo no fueron guardados en los calabozos sino en una habitación que daba a la calle del Divorcio. AGN, “Diligencias sumarias practicadas...", ff. 503v y 511r.

30. Los baqueteros eran personas "fiables" que auxiliaban al alcaide en sus obligaciones cuando era necesario y velaban por el buen comportamiento de los presos durante las noches con el fin de evitar que estos limaran las rejas de la cárcel o las cadenas y grillos que se les ponían. Sánchez Michel, Usos y funcionamientos de la cárcel..., 39-41; Pedro Oliver Olmo, Cárcel y sociedad represora. La criminalización del desorden en Navarra (siglos XVI-XIX) (Bilbao: Servicio Editorial Universidad del País Vasco / Euxkal Herriko Unibertsiatea, 2001); Ignacio Ruiz Rodríguez, "Evolución histórica de las penas privativas de la libertad". En Historia de la prisión. Teorías economicistas. Crítica, dir. por Carlos García Valdés (Madrid: Edisofer, 1997), 79-90.

31. AGN, “Investigación sobre fuga...", f. 218v.

32. Al respecto, Las Siete Partidas señalan que "de noche los deben guardar en esta manera, echándolos en cadenas o en cepos, e cerrando las puertas de cárcel muy bien [...] dejando omes dentro con los presos que los velen con ca[n]dela toda la noche de manera que non puedan limar las prisiones en que yoguieren, nin se puedan soltar en ninguna manera", VII partida, tít. 29, ley VI. Lo anterior se explica a partir de las múltiples reflexiones sobre el castigo que explican la necesidad de la existencia del escarnio como una herramienta utilizada para el mantenimiento del orden. Douglas Hay, "Property, Authority and the Criminal Law". En Albion's Fatal Tree. Crime and Society in Eighteenth-Century England (Nueva York: Pantheon Books, 1975), 17-63; Ricardo Salvatore, Carlos Aguirre y Joseph Gilbert, eds., Crime and punishment in Latin America (Durham / Londres: Duke University 
oportunidades el uso excesivo de estos fue una de las razones que más motivó a los presos a que, a través de la figura del abogado de pobres, los médicos, o incluso sus propios familiares, arguyeran la necesidad de salir de prisión cuanto antes para curarse de las llagas y heridas que estos les causaban. En algunas de estas oportunidades, se apelaba a la ley para reclamar por los tratos que recibían en prisión, porque ponían en riesgo su integridad o que las penurias que estaban pagando en el encierro no eran equiparables a la pena que se les imponía. ${ }^{33}$

\section{AdMinistración CARCELARIA Y LEGISLACIÓN INSTITUCIONAL}

Otro de los elementos que ayudó perpetrar las fugas fue el hecho de que algunos de los reos tuvieran cierto tipo de ventajas respecto a sus compañeros. Las Siete Partidas señalaban que, dependiendo de la fama y honra del preso, el trato que recibiera debía ser diferente. Cuando el procesado tenía riquezas o se le consideraba honrado "non lo deben mandar meter con los otros presos: más debelo hacer guardar en algún lugar seguro", de lo contrario, "si fuere ome vil, devenlo ma[n]dar meter en la cárcel o en otra prisión, que sea bien recabado hasta que lo juzguen". ${ }^{4}$ Por su parte, las Leyes de Indias estipulaban que, cuando se prendiera a una persona honrada, se "señalen la carcelaria conforme a la calidad y gravedad de sus personas y delitos, y guardando las leyes, los hagan poner en las cárceles públicas". ${ }^{35}$

Los casos consultados evidencian que estas leyes no se cumplían al pie de la letra, porque en la cárcel de corte de Santafé todos los presos ocuparon el mismo espacio hasta finales del siglo XVIII, cuando se amplió la cárcel hacia un segundo patio, lugar que fue llamado "el común", presuntamente porque allí eran

Press, 2001); Dario Melossi, El estado del control social (Ciudad de México: Siglo XXI, 1992); Alejandra Araya, "El castigo físico: el cuerpo como representación de la persona, un capítulo en la historia de la occidentalización de América, siglos XVI-XVIII". Historia 2, n. ${ }^{\circ}$ 39 (julio-diciembre 2006): 349-367; Patiño Millán, Criminalidad, Ley Penal...; Franz Dieter Henzel, "Castigo y orden social en la América Latina colonial. El Nuevo Reino de Granada. Un esbozo preliminar". Historia Crítica, n. ${ }^{\circ} 24$ (2003): 141-161.

33. Patiño Millán, Criminalidad, Ley Penal..., 37; Sánchez Michel, Usos y funcionamientos de la cárcel..., 53-66; Juan Sebastián Ariza Martínez, La cocina de los venenos. Aspectos de la criminalidad en el Nuevo Reino de Granada, siglos XVII y XVIII (Bogotá: Universidad del Rosario, 2015), 142-144.

34. Las Siete partidas..., Partida VII, tít. 29, ley IV. De este elemento también da cuenta la Curia Filípica, un compendio jurídico que trata los juicios civiles y criminales eclesiásticos y seculares. Juan de Hevia Bolaños, Curia Philipica, t. 1 (Madrid: Real Compañía de Impresores y Libreros del Reino, 1776), 209.

35. Recopilación de las Leyes de los Reinos de las Indias, lib. 7, tít. 6, ley XV. 
puestos todos los reos que carecían de calidad. Por el contrario, las leyes se adaptaban a la sociedad y los intereses del lugar en el que se aplicaban y se mezclaban con las costumbres o necesidades de quienes habitaban y gobernaban el lugar.

$\mathrm{Al}$ respecto, Velasco señala que se trataban de "arreglos informales" entre los litigantes y los jueces, que en muchas ocasiones buscaban solucionar de forma inmediata las querellas sin que se tuviera que recurrir a procesos escritos. En este tipo de prácticas, las experiencias cotidianas y los mecanismos socioculturales de resolución de problemas, como el perdón o el diálogo, primaban sobre lo que decían las leyes. ${ }^{36}$

Por su parte, el trato que recibían los presos sí era diferenciado. De ahí la importancia de señalar que la cárcel era el lugar de convergencia de varias castas y calidades y que, en algunos casos, había quienes tenían privilegios y ventajas frente a otros. Entre los casos consultados, existen procesos en los que es posible identificar ventajas y privilegios -aunque esta no fuera una constante-, lo que en ocasiones les facilitaría la fuga de la prisión.

En julio de 1792, don Francisco Quiñones, administrador de la Real Hacienda en los Llanos fue puesto en la cárcel de Santafé por los malos manejos que hizo del erario de la hacienda Caribare. Ante el desconocimiento de los administradores de justicia santafereños, solicitó que Pedro Belice, alcalde ordinario de los Llanos le sirviera de fiador para poder salir del encierro. ${ }^{37}$ Según Quiñones, el pago de la fianza y el costo de los abogados que se hicieron cargo de su causa podía cubrirse con los 258 pesos que representaban sus bienes confiscados, y que le fueron retenidos cuando fue aprehendido. En caso de que este monto no fuera suficiente, don Francisco señaló que en el pueblo de Chire permanecían "embargados mis bienes que son súper abundantes para cubrir el citado alcance y para obviar los quebrantos que puede acarrearme" ${ }^{38}$

Lo anterior, además de mostrar que quienes poseían bienes materiales debían entregarlos para su manutención y costos de sus causas durante su prisión, revela que, en ocasiones, los reos que tenían cómo disminuir su estancia en la cárcel accedían a permisos y solicitudes especiales para que esto sucediera y solicitaban el auxilio un procurador para que los defendiera. De lo contrario, debían apelar a la figura del abogado de pobres, que representó

36. Velasco Pedraza, Justicia para los vasallos de su majestad..., 162-167.

37. Los alcaldes ordinarios eran miembros del cabildo y vecinos de la población en la que ejercían su jurisdicción. Estaban a cargo, entre otras cosas, de resolver causas civiles y criminales, realizar las rondas nocturnas, y controlar el buen orden del pueblo que tenían a cargo. Para ampliar información sobre la figura de los alcaldes ordinarios. Ibíd., 108-112.

38. AGN, "Francisco Quiñones encausado y preso por malos manejos de la Real Hacienda, solicita fianza de cárcel", Sección Colonia, fondo Criminales (Juicios), t. 150, doc. 27, f. 984v. Aunque Chire no figure como pueblo o ciudad, puede hacer referencia a las intermediaciones del río que lleva ese nombre en el actual departamento de Casanare, al oriente de Colombia. 
a quienes no tenían cómo pagar por alguien que salvaguardara sus intereses, velara por su integridad, pidiera la liberación de prisión -en caso de que se presumiera inocente del crimen del que se había sindicado-, y en algunos casos ofreciera apoyo espiritual a los reos. ${ }^{39}$ Sin embargo, no siempre los abogados de pobres se presentaban a la defensa de los sindicados o aceptaban el encargo que se les asignaba, y, a través de excusas vanas y "ridículas", argüían que no podían responsabilizarse de las causas por conocer a los sindicados o no tener vestidos adecuados para acudir al juzgado. ${ }^{40}$

Pero no siempre tener bienes, buena honra y fama era sinónimo de gozar de privilegios en la cárcel. $\mathrm{O}$ al contrario, no tener recursos no significaba que no se lograra eventualmente alguna excepción o gracia. En los casos de fuga señalados, los dos escaladores también fueron favorecidos por los alcaides de la prisión, pues ninguno de los dos, a diferencia de los otros reos que permanecían en la cárcel, fueron encerrados en los calabozos, y, en el caso de Varela, no fue asegurado con grillos y cadenas durante la noche.

Francisco Aldao contaba con beneficios en la cárcel como poder entrar y sacar objetos de allí con la intermediación de una mujer, que lo recibió en su casa el día que se fugó. Esto hizo que algunos de los presos, como Lorenzo Moyano manifestara su inconformidad por el hecho de que Francisco tuviera comportamientos particulares en la cárcel sin que se le llamara la atención; por ejemplo, siempre tenía puesta una estera o junco encima de un espejo que cubría el lugar donde se descubrió que había agujereado la pared para escapar; Moyano también señala que:

Observo igualmente [...] que Aldao tenía continuamente tapada la puerta del cuarto con sábanas y sobrecamas en forma de cortinas diciendo que se hallaba enfermo de la vista y siempre estaba acostado [...], y que a excepción de José Manuel

39. Respecto a la figura del abogado de pobres, véase Víctor Uribe-Urán, Vidas honorables. Abogados, familia y política en Colombia. 1780-1850 (Medellín: Fondo Editorial Universidad EAFIT / Banco de la República, 2008), 70. Al respecto, Undurraga señala que los abogados y procuradores de pobres, al estar inmersos en la cultura legal y letrada de la época, conocían los mecanismos necesarios que les permitirían obtener beneficios para quienes defendían. Además de lo anterior, jugaban un papel importante en la restitución y defensa del honor de las personas, un elemento que a fines del período colonial alcanzó a varias esferas sociales. Verónica Undurraga Schüler, Los rostros del honor. Normas culturales y estrategias de promoción social en Chile colonial, siglo XVIII (Santiago: Universitaria, 2013), 69 y 84. Por su parte, González señala que el procurador de pobres estaba encargado de recibir quejas de manera permanente por parte de quienes se consideraban "miserables" en asuntos judiciales. Carolina González Undurraga, "Las posibilidades del registro judicial para rastrear la recepción de saberes sobre justicia y gobierno", Nuevo Mundo Mundos Nuevos (2012), DOI: 10.4000/ nuevomundo.62418.

40. Uribe-Urán, Vidas honorables..., 70-77; Juan Carlos Vélez, "Abogados, escribanos, rábulas y tinterillos. Conflictos por la práctica del derecho en Antioquia, 1821-1843", Estudios políticos, $n .^{\circ} 32$ (2008): 13-51. 
Pérez Sotelo, que se fue con Aldao, a ninguna [persona] dejaba dentrara al cuarto, pues aunque comía con el Manuel Pérez el sastre citado, [...] también lo privó de que entrase a d[ic]ho cuarto, pues aunque prosiguió dándole la comida, se la mandaba afuera y que ni aun al alcaide Juan López le permitía que dentrara. ${ }^{41}$

Llama la atención que este tipo de beneficios sobre los que ni siquiera el alcaide interino se manifestó, fueran dados a alguien que no tenía calidad de "don" ni fuera reconocido los demás reos como notable, sino que, por el contrario, fuera considerado peligroso por parte de los visitadores de la Audiencia, quienes recomendaron que al hombre le pusieran cadenas para que no intentara escaparse.

Esto permite hablar de otro tipo de relaciones que se establecía entre quienes habitaban y gobernaban la cárcel. No siempre se trató de camaradería y benevolencia de parte de las autoridades hacia los presos, sino que también había sentimientos de temor hacia los reos. En el caso señalado, podría señalarse, Aldao se consideraba una persona tan peligrosa que hasta los guardias y el alcaide le temían. Por eso se le toleraba tener privilegios como estar solo, permanecer escondido y no llamarle la atención aun cuando su comportamiento no era el habitual. El miedo, muchas veces presente en el espacio carcelario, en esta ocasión favorecía a un preso y ponía en debilidad la figura autoritaria del alcaide y de los guardias.

Por otro lado, quienes pertenecían a una calidad notable o supieran escribir podían redactar los autos que les permitieran pedir perdón, congraciarse con la sociedad (es decir, enmendar el daño hecho a través de buenas obras y beneficios para la ciudad) o hacer peticiones particulares para que su condición se viera reflejada en el trato que merecía mientras estaban en prisión. Al respecto puede citarse el caso de don Salvador Bernabeu de Reguart -administrador general y de terreno de las fábricas de salitre y pólvora de Tunja, prendido por orden del juzgado eclesiástico-, quien el 5 de marzo de 1787 redactó un auto para que autorizaran la entrada de su mujer a la cárcel para que le hiciera compañía marital, pues hacía 19 meses que no la veía y "a cortos días de haberme matrimoniado con esta niña se me separó con la prisión y esta dilatada desunión, falta de tacto y familiar comunicación, temo justamente la desamore y retraiga del conyugal afecto". ${ }^{42}$

En su petición, don Salvador recurría al hecho de que aún no se había determinado si era o no culpable del delito que se le acusaba, lo que haría que su estancia en la cárcel fuera prolongada, pues la cárcel era un lugar de paso y pre-

41. AGN, "Diligencias sumarias practicadas...", ff. 514r-v.

42. AGN, "Petición de Salvador Bernabeu de Reguart para que pudiera visitarlo en la cárcel su mujer", Sección Colonia, fondo Criminales (Juicios), t. 14, doc. 31, f. 880r. 
vención y no el lugar de pagar la condena. ${ }^{43}$ Además, Bernabeu de Reguart apelaba que se le diera alivio a su necesidad bajo el argumento que su petición "no se ha negado a otros sujetos de distinción que han estado igualmente presos". ${ }^{44}$

Lo que muestra la importancia que se daba a los casos de presos que pertenecían a una calidad superior, cuyas peticiones en la mayoría de los casos eran acogidas, mientras que las de otros reos eran rechazadas por orden de los oficiales de la Audiencia. Tal es el caso de cinco personas "rematadas a obras públicas", que solicitaban que se les pagara más de medio real por su trabajo, pues lo poco que ganaban no les alcanzaba para su alimentación y manutención en la cárcel, lo que los había obligado a "vender y empeñar hasta nuestras ruanas para el sustento diario que es irremisible". ${ }^{45}$

El hecho de que los reos pidieran que se aumentaran los ingresos de su trabajo en obras públicas muestra algunas de las dificultades de vida dentro de la cárcel. En muchas oportunidades, los mismos reos debían costear su alimentación y vestuario mientras permanecían en encierro, y, en caso de que enfermaran, también debían pagar los costos que su alivio demandara. Según la petición, el medio real que les pagaban a diario era utilizado para comprar el almuerzo, y hacía falta que les dieran otra suma igual con el fin de ganar el sueldo que les habían prometido cuando fueron condenados al presidio. Sin embargo, la petición de los reos fue negada en dos oportunidades, bajo el argumento de que los condenados a obras públicas solo debían ganar tres cuartillos diarios, por lo que la queja de los reos se consideraba infundada. ${ }^{46}$

Vivir de la práctica del presidio urbano, también llamado obras públicas, era una de las mayores dificultades que enfrentaban los reos. ${ }^{47} \mathrm{Sin}$ embargo, dadas las dificultades de vigilancia que había en el mismo, también implicaba una oportunidad de fuga. Así lo relatan los señores de la Audiencia, quienes en un auto escrito en junio de 1807 señalan que los presos que se enviaban desde Santafé para que trabajaran en las salinas de Zipaquirá (en donde recibían algún tipo de remuneración económica para costear su estancia en prisión), se escapaban con frecuencia dado que, en dicha población, no había una casa en la que fueran refugiados y encadenados los reos, una

43. Las Siete Partidas..., Partida VII, tít. 29, ley 15; Sánchez Michel, Usos y funcionamientos de la cárcel..., 20-21. Respecto a la cárcel como pena ver Rebagliati, "Caridad y control social...", 6; AGN, "Diligencias de visitas de cárcel...", ff. 7r-381v.

44. AGN, "Petición de Salvador Bernabeu...", f. 880 r. Énfasis añadido.

45. AGN, "Los presos de la cárcel de Santafé condenados a servir en obras públicas de la capital, reclaman el pago completo y equitativo de sus salarios", Sección Colonia, fondo Miscelánea, t. 125, doc. 9, ff. 86r-92r.

46. Ibíd., ff. 89v-90r.

47. Guillermo Sosa Abella, Labradores, tejedores y ladrones. Hurtos y homicidios en la Provincia de Tunja. 1745-1810 (Bogotá: Instituto Colombiano de Cultura Hispánica, 1993), 49. 
vez terminaran la jornada laboral, sino que estos eran dejados sin vigilancia.

Por esta razón, se señala que "es preciso que se realice la construcción de la casa con sus distribuciones adecuadas, parte para habitación de los presidiarios y parte para la tropa que ha de servir de auxilio a su seguridad", pues de lo contrario, sería inútil que se condenara a los criminales a este castigo, ya que se les estaba dando la oportunidad de escapar con facilidad. ${ }^{48} \mathrm{Al}$ parecer las fugas en el presidio no eran tan complicadas como podría pensarse, y muchos de los reos lograban quitarse los grilletes mientras limpiaban las cañerías o empedraban las calles de las ciudades. ${ }^{49}$ La preocupación por la poca vigilancia a los presos también tuvo lugar en Santiago de Chile, en donde a fines del siglo XVIII un fiscal de la Real Audiencia pidió que se pensara en crear otros lugares de custodia y seguridad de los criminales, pues la cárcel por sí sola era insuficiente para cumplir esta tarea. ${ }^{50}$

\section{Los CASOS DE FUGA DE LA REAL CÁRCEL}

La forma cómo vivían quienes permanecían en encierro y las relaciones sociales que se establecían entre los reos y quienes los vigilaban, son un elemento que permite analizar el porqué de las fugas. El hecho de que durante el período de estudio se presentaran escalamientos de la real cárcel y que en las visitas se registraran a algunos reos sindicados del delito de fuga, muestra que, en la práctica, eran otras reglas las que regían el comportamiento de las autoridades y de los presos dentro de la institución, muchas de las cuales no estaban consignadas por escrito, sino que formaban parte de la cultura local. ${ }^{51}$

Ignacio Varela, además de hablar con su esposa y varios conocidos días antes de ejecutar la fuga, pudo estar fuera de su celda hasta pasadas las nueve de la noche, sin que se le llamara la atención por esto. Miguel Gerónimo Páramo, soldado de la compañía de caballería y guardia de la cárcel, señaló que la noche de la fuga, cuando ya todos los reos estaban encerrados y los guardias se disponían a dormir, Varela pasó por el zaguán donde estaban los soldados, se recostó sobre la reja que da la entrada al patio de la cárcel y les

48. AGN, "Salinas de Zipaquirá. Se destinan los presidiarios para la explotación de ellos", archivo Colonia, fondo Policía, t. 2, doc. 1, ff. 1r-15v.

49. Sosa Abella, Labradores, tejedores y ladrones..., 52.

50. Argouse, "Archivos de la vulnerabilidad...", 198.

51. AGN, "Investigación sobre fuga...", ff. 216r-231v; AGN, "Juicio seguido a José Torres, Juan de Dios Sanabria, Juan Ignacio Daza y otros reos por haber realizado fuga de la cárcel", Sección Colonia, fondo Criminales (Juicios), t. 148, doc. 2, ff. 86r-196v. Respecto a las costumbres y dinámicas de la cotidianidad que no aparecen en las leyes véase Edward P. Thompson, Costumbres en común (Barcelona: Crítica, 1991). 
dijo que había pedido que le pasaran un cuartillo de chicha y que se iría a dormir después de recibirlo. Más adelante, Páramo señala que "a cosa de las tres y media de la mañana salió de su cuarto a orinar y no reconoció entones la puerta abierta ni ninguna novedad y retirándose a su cuarto se volvió a quedar dormido hasta las cinco de la mañana en que estándose ya vistiendo, oyeron que el presidente de los presos avisaba que se había ido Varela". ${ }^{52}$

Después de haber sido alertados sobre la fuga, Ignacio Salgado llamó a su hermano el alcaide para que abriera la puerta que daba hacia el patio, y que:

Empezó a reconocer por él la parte por donde pudo haberse [h]echo la huida y al parecer no se ofreció otra que la de las ventanas según dijo el presidente, aunque no se halló soga alguna, ni tejas caídas ni quebradas, por lo que todos juntos fueron a reconocer por las tapias de la puerta de la Aud[icenci]a y no hallaron en ellas caída de ninguna teja por lo interior ni exterior de la calle y solamente repararon un rejo que co[l]gaba de ella y pendía de un brazo de un árbol de papayo que está en la huerta de la Aud[ienci]a a gran distancia de d[ic]has tapias exteriores. ${ }^{53}$

El caso de la fuga de Varela parecía ser más un misterio por la ausencia de pruebas que indicaran que había podido trepar las paredes de la cárcel, o abrir las puertas y ventanas del recinto. La situación únicamente empieza a esclarecerse días después de la fuga, cuando Lucas Fernández, compañero de celda de Ignacio, señala que el hermano del alcaide les había entregado copia de las llaves esa noche, con el fin de que él y Varela pudieran reclamar el cuartillo de chicha que habían comprado y que fue entregado por una mujer -quizás proveniente de la chichería que colindaba con la cárcel, construida en el lugar donde debía levantarse el palacio virreinal- ${ }^{54}$

Lo interesante de esta declaración es que permite, por un lado, conocer que los presos tenían derecho a consumir chicha dentro de la cárcel-siempre y cuando esta se vendiera al precio justo-,${ }^{55}$ y, por el otro, que el alcaide no era el único que tenía copia de las llaves del recinto, sino que las había compartido con su hermano, a pesar de que en su declaración da a entender que solo él las tenía. Además, llama la atención que Ignacio Salgado tuviera tanta confianza en los reos y dejara que los mismos las utilizaran, sin tener mayor reparo sobre el uso que estos hacían de ellas, ni sospechar de sus actividades.

La declaración de Fernández fue motivo suficiente para que, después de ser informados de los hechos el virrey y los miembros de la Audiencia, se ordenara la captura del alcaide Francisco Salgado, bajo el argumento de que la fuga se había

52. AGN, "Investigación sobre fuga...", f. 224r. Énfasis añadido.

53. Ibíd., f. 223v. Énfasis añadido.

54. Ibíd., f. 225v.

55. Recopilación de las Leyes de los Reinos de las Indias, lib. 7, tít. 6, ley XIII. 
realizado por la incompetencia del oficial para realizar sus labores y el no haber cumplido con las leyes y sus instrucciones sobre el cuidado de los reos. A lo anterior, se suma el hecho de que confiara en las palabras de la mujer de Varela y no sospechara que ella había pedido que la noche de la fuga no se le pusieran grilletes a su esposo por la supuesta orden de la Audiencia que nunca fue corroborada por escrito, ni lo hubiera encerrado en un calabozo, como sí había ocurrido con los otros presos. Por eso, luego de adelantar las investigaciones se determinó que:

Agregándose a esto el q[u]e no se [h]a encontrado forma en escala, huella, ni vestigio en lo interior ni exterior de la cárcel y prudentem[en]te creen algunos de los testigos que solo pudo ser la salida por la puerta, en cuya atenc[ió]n se ha de servir V[uestra] A[lteza] de imponerle a el enunciado Salgado la pena de un año de prisión que dispone la ley 12, tít. 23 lib. 4 de la Recopilación de Castilla, mandando librar la correspond[ien]tes. ${ }^{56}$

El caso de Francisco Salgado es interesante porque permite ver el tránsito de un oficial de la Audiencia a cargo de la cárcel de corte, a ser uno de los tantos reos que habitaban en ella. La negligencia del alcaide y la laxitud que el mismo y su hermano tenían con los presos, lo llevaron ser inhabilitado de por vida de su puesto. Llama la atención ver cómo los argumentos que utilizaban los presos para narrar a los abogados y médicos su estado de detención, ahora pasaban a ser el estandarte del alcaide que, a través de súplicas y a veces recurriendo al padecimiento, exigía que lo sacaran de la cárcel y lo reasignaran a su puesto. ${ }^{57}$

Por su parte, en el proceso que se siguió por el escalamiento de José Aldao y José Manuel Pérez Sotelo, los motivos que permitieron la fuga de los reos fueron otros. Según la declaración de don Baldiri Vila, alarife y maestro mayor de albañilería que hizo el reconocimiento del estado de la cárcel luego de la fuga, ${ }^{58}$ los prófugos tenían un cincel, un martillo y un cuchillo grande que, además de ayudarles a quitarse los grillos durante la noche, les permitió descascarar las junturas de barro de las piedras que formaban la pared de la cárcel y que daban a la calle del Divorcio. ${ }^{59}$

No debe considerarse extraño que los presos tuvieran acceso a herramientas de este tipo, pues muchos de ellos las utilizaban para construir y

56. AGN, "Investigación sobre fuga...", f. 226r.

57. En el período de estudio lo miserable hacía referencia a la infelicidad, la desdicha o el infortunio. Real Academia de la Lengua, Diccionario de Autoridades (1734).

58. El alarife es el maestro que tiene aprobación para apreciar y dirigir obras arquitectónicas. También se le conoce como maestro de albañilería. Real Academia de la Lengua, Diccionario de Autoridades (1726), t. 1, http:/ / web.frl.es /DA.html.

59. José Belvéz, "Costado sur de la antigua Plaza de Bolívar", Papel Periódico Ilustrado, n. ${ }^{\circ}$ 93, año IV (1885): 330-339; Benjamín Gaitán Villegas, La plaza de Bolívar. 47 años de historia de Bogotá (Bogotá: Academia de Historia de Bogotá / Universidad de América, 2010). 
vender artesanías que les permitían conseguir el sustento diario. Además, algunos de ellos eran sentenciados a obras públicas y trabajaban con herramientas de este tipo. Lo que sí llama la atención es que no les retuvieran los instrumentos durante las noches. Sin embargo, los reos no hubieran podido escapar de no haber sido porque alguien que permanecía afuera ayudó a quitar la piedra de dos cuartas, seis pulgadas de largo y dos cuartas de ancho que fue retirada de la fachada principal de la real cárcel. ${ }^{60}$

Según las declaraciones de los testigos, algunos días antes de la fuga Aldao había presentado una solicitud para ser liberado, pero había sido negada por los miembros de la Audiencia, lo que lo motivó a hacer el escalamiento. Sin embargo, el alcaide Barba tenía cierta compasión de él y había mandado a su interino que, durante su ausencia, permitiera a Francisco presentar autos de petición durante la visita de cárcel del sábado y, además, consintiera que Aldao, Pérez Sotelo y Manuel Buitrago -un sastre procesado por heridas que salió de la cárcel antes de la fuga-pudieran dormir en un cuarto cercano a la puerta de la cárcel y no en los calabozos, como era costumbre. ${ }^{61}$

Lo anterior muestra que las preferencias que tenían algunos reos fueron comunes en la cárcel de corte de Santafé, pero que pudo llevar al desorden dentro de ella y facilitó el escalamiento de algunos de los reos. Además, estas preferencias no obedecían a la calidad de las personas presas, sino que respondía a relaciones de amistad o temor -entre los reos y los oficiales de la cárcel-, o situaciones particulares de los presos como enfermedades o novedades registradas de las visitas.

La ausencia del alcaide principal de la cárcel también fue una de las causas en esta fuga, más aún si se tiene en cuenta que no solo para algunos de los reos, sino también quienes conocían al carcelero interino Juan Nepomuceno López, dieron cuenta de su negligencia y falta de experiencia para ejercer el oficio. Según varias declaraciones, se le había advertido sobre el comportamiento de los fugitivos sin que él hiciera mayor comentario al respecto, e incluso el día de la fuga hubo vecinos de la cárcel que, ante el bullicio de la piedra cayendo hacia la calle, lo llamaron varias veces gritando: "[i]Juanito, que se van los presos [!]". ${ }^{62}$

La declaración de Josefa Castro, criada del alguacil mayor de la Audiencia, hace énfasis en el comportamiento de López. Según la mujer, siendo las once de la noche oyó ruidos en la calle y se asomó por la ventana a ver lo que ocurría y se encontró con la imagen una persona frente a la cárcel, aunque no pudo distinguir de quién se trataba, por lo que salió a la calle en compañía

60. AGN, “Diligencias sumarias... practicadas...", f. 504r y 511r.

61. Ibíd., f. 511r.

62. Ibíd., f. 504r. Énfasis añadido. 
de una esclava y se encontró con que había "una piedra bastante desencajada en la tapia y ya para caer"; al ver lo ocurrido, corrió a una casa cercana a la cárcel en donde se hallaba durmiendo López y le avisó de la posible fuga, pero que este le respondió "que se fuese a la mierda, que qué presos se habían de ir, que ese era [un] disparate", por lo que la mujer se vio obligada a ir a la casa de Barba y despertar a su esposa, y justo en este momento oyó la piedra caer de la tapia y vio que de allí "salieron dos bultos, primero uno vestido de blanco, que se quedó en el suelo asentado por un rato, después del cual se fue con otro que salió de ruana negra". ${ }^{63}$

Los casos reseñados muestran que la seguridad de la cárcel a fines del siglo XVIII era precaria, algo que ya había sido anotado por Beatriz Patiño para el caso de la provincia de Antioquia y por Guillermo Sosa para el de Tunja, y que los presos únicamente debían esperar el descuido de los guardias, apelar a la compasión de los mismos o contar con instrumentos necesarios para liberarse de los grillos y huir. ${ }^{64}$ A lo anterior se suma la gran cantidad de reos que por momentos hubo encerrados en la cárcel de corte de Santafé, lo que dificultó la tarea de los guardias de custodiar a todos los que vivían allí.

Finalmente, es importante señalar que, a pesar de las fugas que tuvieron lugar en la cárcel de corte de Santafé y de los percances en su administración, la custodia de los reos no siempre fue insatisfactoria y el personal que en ella trabajaba -alcaide, guardias, capellán y ocasionalmente un médico- velaron por su buen funcionamiento y por el bienestar de los presos. Durante el período de estudio, la cárcel continuó recibiendo reos de diferentes lugares del virreinato, muchos de los cuales venían a enfrentar litigios de tipo criminal desde diferentes jurisdicciones del Nuevo Reino de Granada. Además de lo anterior, vale la pena tener en cuenta que el control de la sociedad no reside únicamente en la correcta administración de la cárcel o el papel de los alcaides y los guardias, sino que excede los límites y la existencia de la institución, y se relaciona con el contexto y las normas sociales de comportamiento de los habitantes de Santafé a fines del período colonial.

\section{Conclusiones}

A pesar de contar con varias leyes que ayudaran al correcto funcionamiento de la institución, la real cárcel de corte de Santafé tuvo falencias en su organización, muchas de las cuales derivaron en una serie de dificultades para los

63. Ibíd., ff. 515r-v.

64. Respecto al caso de Antioquia véase Patiño Millán, Criminalidad, Ley Penal..., 3437; para el de Tunja, Sosa Abella, Labradores, tejedores y ladrones..., 79-83. 
alcaides, quienes tuvieron que asumir algunas de las consecuencias de la mala administración, incluso aquellas que no dependían de su mandato sino de las disposiciones de la Audiencia. Pero el mal funcionamiento de la cárcel no es tampoco un elemento casual, sino que está inscrito dentro de los patrones de conducta de la sociedad. Los santafereños que habitaron la ciudad a fines del siglo XVIII, como en cualquier otra sociedad, no seguían al pie de la letra las leyes y los dictámenes de las autoridades, lo que dificultaba la organización social y hacía que la cárcel no pudiera cumplir cabalmente con su objetivo institucional.

La falta de seguridad y las condiciones de desamparo en que se encontraban los presos, sumado al hecho de que a fines del período colonial la población que habitó en el recinto aumentó considerablemente, hizo que las condiciones físicas de la cárcel tampoco fueran las mejores y que incluso la estructura material tuviera falencias estructurales, a las que se sumaron los casos de hacinamiento y propagación de enfermedades entre los presos.

Además de las fugas, otra forma de manifestación en contra del encierro y las formas de vida en el presidio fueron las quejas y súplicas que muchos de los presos elevaron ante las autoridades, con el fin de dar cuenta de las dificultades de vida que tenían. Muchas de estas peticiones se hicieron públicas ante la Audiencia a través de las visitas. Sin embargo, fue más común que los presos se valieran de terceros para pedir fianzas o liberaciones; de ahí el poder encontrar súplicas por parte de los familiares de los reos, los médicos que los examinaban o los abogados que se encargaban de sus casos, en los que apelando a las obras de misericordia, el perdón y la gracia de Dios y de los representantes del rey, pedían que fueran puestos en libertad o se les otorgaran fianzas para salir de la cárcel.

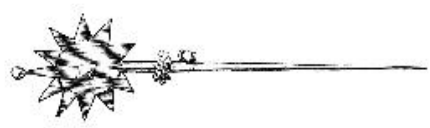

\section{FuENTES Y BIBLIOGRAFíA}

FUENTES PRIMARIAS

\section{Archivos}

Archivo General de la Nación (AGN). Bogotá, Colombia.

Fondo Criminales (Juicios).

Fondo Historia Eclesiástica.

Fondo Miscelánea.

Fondo Policía.

Fondo Real Audiencia-Cundinamarca. 


\section{Fuentes primarias impresas}

Belvéz, José. “Costado sur de la antigua Plaza de Bolívar”. Papel Periódico Ilustrado, n. ${ }^{\circ}$ 93, año IV (1885): 330-339.

Brocar, Juan [ied.?]. Las Siete Partidas del sabio rey don Alfonso Nono. 1542 [1265].

Durán y Díaz, Joaquín. Estado general de todo el Virreinato de Santafé de Bogotá. Edición facsimilar. Bogotá: Banco de la República, 2012 [1794].

Escriche, Joaquín. Diccionario razonado de Legislación y Jurisprudencia. París: Librería de la viuda de Boured, 1931 [1847].

Hevia Bolaños, Juan de. Curia Philipica. T. 1. Madrid: Real Compañía de Impresores y Libreros del Reino, 1776.

Novísima recopilación de las leyes de España. París: Librería de don Vicente Salvá, 1846.

Recopilación de las Leyes de los reinos de las Indias. Madrid: Antonio Pérez de Soto, 1774 [1680].

\section{FUENTES SECUNDARIAS}

Alzate Echeverri, Adriana María. Geografía de la lamentación. Institución hospitalaria y sociedad, Nuevo Reino de Granada, 1760-1810. Bogotá: Universidad del Rosario / Pontificia Universidad Javeriana, 2012.

Araya, Alejandra. "El castigo físico: el cuerpo como representación de la persona, un capítulo en la historia de la occidentalización de América, siglos XVI-XVIII". Historia 2, n. 39 (julio-diciembre 2006): 349-367.

Argouse, Aude. "Archivos de la vulnerabilidad. Reos en Santiago de Chile (16501780)". Clío y crimen, n. ${ }^{\circ} 12$ (2015): 202-214.

Ariza Martínez, Juan Sebastián. La cocina de los venenos. Aspectos de la criminalidad en el Nuevo Reino de Granada, siglos XVII y XVIII. Bogotá: Universidad del Rosario, 2015.

Carasa Soto, Pedro. “Cambios en la tipología del pauperismo en el Antiguo Régimen". Investigaciones históricas: Época moderna y contemporánea, n. ${ }^{\circ} 7$ (1987): 131-150.

Gaitán Villegas, Benjamín. La plaza de Bolívar. 47 años de historia de Bogotá. Bogotá: Academia de Historia de Bogotá / Universidad de América, 2010.

González Undurraga, Carolina. "Las posibilidades del registro judicial para rastrear la recepción de saberes sobre justicia y gobierno". Nuevo Mundo Mundos Nuevos (2012). http: / / nuevomundo.revues.org/ 62418; DOI: 10.4000 / nuevomundo.62418.

Hay, Douglas. "Property, Authority and the Criminal Law". En Albion's Fatal Tree. Crime and Society in Eighteenth-Century England. Nueva York: Pantheon Books, 1975.

Henzel, Franz Dieter. “Castigo y orden social en la América Latina colonial. El Nuevo Reino de Granada. Un esbozo preliminar". Historia Crítica, n. 24 (2003): 141161. 
Herzog, Tamar. "El rescate de una fuente histórica: Los libros de visita de cárcel (el caso de Quito, 1738-1750)". Anuario de Estudios Americanos 52, n. 2 (1995): 251261.

Martín, Norman. "Pobres, mendigos y vagabundos en la Nueva España, 1702-1766: Antecedentes y soluciones presentadas". Estudios de historia novohispana 8 (1985): 99-126.

Melossi, Dario. El Estado del control social. Ciudad de México: Siglo XXI, 1992.

Olmo, Pedro Oliver. Cárcel y sociedad represora. La criminalización del desorden en Navarra (siglos XVI-XIX). Bilbao: Servicio Editorial Universidad del País Vasco / Euxkal Herriko Unibertsiatea, 2001.

Patiño Millán, Beatriz. Criminalidad, Ley Penal y estructura social en la provincia de Antioquia, 1750-1820. Bogotá: Universidad del Rosario, 2013.

Real Academia Española de la Lengua. Diccionario de las autoridades. Madrid: 1837. http:/ / web.frl.es/DA.html.

Rebagliati, Lucas Esteban. "Caridad y control social en el Buenos Aires virreinal: El caso de los Defensores de pobres (1776-1809)". Ponencia presentada en las Segundas Jornadas Nacionales de Historia Social. Córdoba, 2009.

Ruiz Rodríguez, Ignacio. "Evolución histórica de las penas privativas de la libertad". En Historia de la prisión. Teorías economicistas. Crítica, dirigido por Carlos García Valdés, 79-90. Madrid: Edisofer, 1997.

Salvatore, Ricardo, Carlos Aguirre y Joseph Gilbert, editores. Crime and Punishment in Latin America. Durham / Londres: Duke University Press, 2001.

Sánchez Michel, Valeria. Usos y funcionamientos de la cárcel novohispana. El caso de la Real Cárcel de Corte a finales del siglo XVIII. Ciudad de México: El Colegio de México, 2008.

Sosa Abella, Guillermo. Labradores, tejedores y ladrones. Hurtos y homicidios en la Provincia de Tunja. 1745-1810. Bogotá: Instituto Colombiano de Cultura Hispánica, 1993.

Thompson, Edward P. Costumbres en común. Barcelona: Crítica, 1991.

Undurraga Schüler, Verónica. Los rostros del honor. Normas culturales y estrategias de promoción social en Chile colonial, siglo XVIII. Santiago: Universitaria, 2013.

Uribe-Urán, Víctor. Vidas honorables. Abogados, familia y política en Colombia. 1780-1850. Medellín: Fondo Editorial Universidad EAFIT / Banco de la República, 2008.

Vásquez Hahn, María Antonieta. “Para la 'felicidad pública'. El barón de Carondelet y el establecimiento del presidio urbano de Quito". En Carondelet: Una autoridad colonial al servicio de Quito. Quito: Fonsal, 2007.

Velasco Pedraza, Julián Andrei. Justicia para los vasallos de su Majestad. Administración de justicia en la Villa de San Gil, siglo XVIII. Bogotá: Universidad del Rosario, 2015.

Vélez, Juan Carlos. “Abogados, escribanos, rábulas y tinterillos. Conflictos por la práctica del derecho en Antioquia, 1821-1843". Estudios políticos, n. ${ }^{\circ} 32$ (2008): $13-51$. 
PROCESOS

REVISTA ECUATORIANA DE HISTORIA

\title{
El fomento a la educación básica en el Distrito del Sur en tiempos de la República de la Gran Colombia*
}

\author{
Promoting basic education in the Southern District \\ at the time of the Republic of Gran Colombia
}

Roger Pita Pico

Academia Colombiana de Historia rogpitc@hotmail.com

DOI: http: / / dx.doi.org/10.29078/ rp.v0i46.648

Fecha de presentación: 3 de agosto de 2017 Fecha de aceptación: 12 de octubre de 2017

Artículo de investigación

* Este artículo es parte del proyecto de investigación “Educación, progreso y nación: el impulso a la educación pública en la Gran Colombia", financiado con recursos propios. El autor agradece a los lectores anónimos del artículo, cuyas observaciones y sugerencias contribuyeron a mejorar la versión final del manuscrito. 
RESUMEN

Este artículo examina los avances y retrocesos en el proceso de expansión de las escuelas públicas en el Ecuador, durante la Gran Colombia. El proyecto educativo se desarrolló en una etapa de transición caracterizada por el choque de mentalidades entre el Antiguo Régimen español y el nuevo sistema republicano, este último con tendencia hacia una educación secular e incluyente. Tras las guerras de Independencia y ante la situación generalizada de crisis económica y el déficit fiscales, las escuelas públicas recibieron financiamiento privado. Finalmente, el proyecto educativo fue una ocasión propicia para difundir la idea de progreso y los principios liberales, consolidar la legitimidad del sistema político y exaltar los beneficios de la Patria.

Palabras clave: educación básica, escuelas, estudiantes, enseñanza, Gran Colombia, Ecuador, siglo XIX.

ABSTRACT

This article examines the progress and setbacks experienced when public schooling spread in Ecuador at the time of the Republic of Gran Colombia. This educational initiative was developed during a transition phase characterized by the clash between the mindset of the old Spanish regime and that of the new Republican system, the latter tending toward lay and inclusive education. After the Wars of Independence and in view of widespread economic recession and

fiscal deficits, public schools benefited from private funding. Ultimately, this educational initiative was a favorable opportunity to disseminate the idea of progress and liberal principles, consolidate the political system's legitimacy, and extol the benefits of the Nation.

Keywords: Basic education, schools, students, teaching, Gran Colombia, Ecuador, nineteenth century.

Roger Pita Pico

Politólogo con Opción en Historia de la Universidad de los Andes (Bogotá, Colombia), magíster en Estudios Políticos de la Pontificia Universidad Javeriana. Su labor como investigador le ha permitido profundizar sobre varias temáticas como: esclavitud, mestizaje, celebraciones políticas y educación en el período de dominio hispánico, Independencia y primeros años de la República. Actualmente es director de la Biblioteca "Eduardo Santos" de la Academia Colombiana de Historia. 


\section{INTRODUCCIÓN}

En tiempos coloniales las escuelas de primeras letras en la Audiencia de Quito tenían una cobertura muy limitada. Algunos planteles eran anexos a los colegios pero la mayoría eran fundados por las comunidades religiosas. ${ }^{1}$ Existían además algunos cuantos establecimientos de carácter privado. En realidad las escuelas no eran una prioridad pues buena parte de los esfuerzos oficiales estaban dirigidos hacia los niveles de educación media y superior.

Con la llegada de los republicanos al poder a comienzos del siglo XIX en el marco del proceso de Independencia, se dan algunos avances en el intento por reforzar esta primera etapa educativa, orientándola cada vez más hacia el camino de la secularización.

Desde finales del período colonial, el pensamiento pedagógico ecuatoriano había sido permeado por el pensamiento liberal promovido por el movimiento de la Ilustración y por las corrientes ideológicas de la Revolución Francesa.

El presidente Simón Bolívar fue uno de los más comprometidos con la causa de la instrucción pública. En el discurso de apertura del Congreso Constituyente de Angostura, pronunciado el 15 de febrero de 1819, lanzó fuertes críticas al legado colonial español:

Uncido el pueblo americano al triple yugo de la ignorancia, de la tiranía y del vicio, no hemos podido adquirir ni saber ni poder ni virtud. Discípulos de tan perniciosos maestros, las lecciones que hemos recibido y los ejemplos que hemos estudiado, son los más destructores. Por el engaño se nos ha dominado más que por la fuerza, y por el vicio se nos ha degradado más bien que por la superstición. La esclavitud es la hija de las tinieblas; un pueblo ignorante es un instrumento ciego de su propia destrucción. ${ }^{2}$

Más adelante, Bolívar hace un llamado a este máximo órgano legislativo: "La educación popular debe ser el cuidado primogénito del amor paternal del Congreso. Moral y luces serán los polos de una República, moral y luces son nuestras primeras necesidades" ${ }^{3}$

1. Sobre la influencia de la Iglesia en la educación en tiempos del dominio hispánico véase Julio César Delgado Ayora, “Iglesia y educación pública en Quito y en Cuenca a fines del período colonial (1750-1809)" (tesis de licenciatura, Universidad de Cuenca, 2011).

2. Rufino Blanco-Fombona, comp., Simón Bolívar. Discursos y proclamas (París: Garnier Hermanos, 1913), 39.

3. Ibíd., 64-65. 
El 17 de diciembre de 1819 los congresistas reunidos en Angostura expidieron la Ley Fundamental que dio nacimiento a la República de la Gran Colombia. En adelante, el poder ejecutivo central quedaba a cargo del presidente Simón Bolívar y del vicepresidente Francisco de Paula Santander, y su territorio fue dividido en tres grandes departamentos: Venezuela, Quito y Cundinamarca, cuyas capitales serían Caracas, Quito y Bogotá, respectivamente. $^{4}$

Guayaquil había proclamado en 1820 su independencia y de inmediato realizó esfuerzos con miras a instalar algunas escuelas. Al año siguiente, en la ciudad de Cuenca el general Antonio José de Sucre, con el apoyo del cabildo, aumentó de cuatro a siete el número de escuelas mixtas mientras que en Riobamba instó a la sala capitular para crear nuevos planteles. ${ }^{5}$

Este artículo se propone analizar cómo el gobierno afrontó durante los primeros años de vida republicana en Ecuador los retos de expansión y financiación de las escuelas públicas de primeras letras en medio de un ambiente social, económico y político adverso.

Interesa además en este trabajo revisar en profundidad el papel que cumplieron las escuelas públicas dentro de la meta de consolidación del proyecto republicano y de los principios inherentes a esta apuesta política. En cierta medida, a través del proyecto educativo el gobierno, bajo el especial liderazgo del presidente Simón Bolívar, del vicepresidente Francisco de Paula Santander y del secretario del Interior don José Manuel Restrepo, buscó estratégicamente entronizar los valores liberales y fortalecer la legitimidad de un sistema político que intentaba consolidarse como una verdadera alternativa en contraposición al antiguo régimen implantado en estas tierras por más de tres siglos.

Estos propósitos sucedieron en una etapa de transición en la cual era evidente el choque de mentalidades entre los valores del antiguo régimen español y los principios liberales. El movimiento ilustrado había propiciado desde el siglo XVIII unos procesos de ruptura al promover no solo la educación sino también la lectura, la libertad de imprenta y la fundación de bibliotecas. ${ }^{6}$ Todos estos esfuerzos encontraron eco en el período de forma-

4. Ley Fundamental de la República de Colombia (Angostura, 1819), 1. Tomado de Biblioteca Nacional de Colombia (BNC), Fondo Pineda, t. 852, pieza 14.

5. Jorge Núñez Sánchez, "Inicios de la educación pública en el Ecuador". Procesos: revista ecuatoriana de historia, n..$^{\circ} 13$ (1999): 18-21. Es muy reconocida, además, la gestión adelantada años después por el general Antonio José de Sucre en el impulso de la educación primaria y secundaria en Bolivia.

6. Guadalupe Soasti Toscano, "Pedagogía política ilustrada: De vasallo a ciudadano, lo que produjo el conocimiento de los Derechos del Hombre y del Ciudadano". En Politica, participación y ciudadanía en el proceso de Independencia de la América Andina, comp. por Guadalupe Soasti (Quito: Fundación Konrad Adenauer, 2008), 293-318. 
ción de la República pues se tenía el convencimiento de que se consolidaría un nuevo humanismo apoyado en la razón que abriría el camino hacia la inclusión social, la autonomía y la libertad política que permitiría defender el proyecto independentista. ${ }^{7}$

En ese contexto, se pretendía extender la cobertura de las escuelas para difundir los valores republicanos y contribuir a la restructuración del orden social a través sobre los beneficios resultantes de los méritos dentro de un nuevo esquema de valores basado ya no en la nobleza y en los privilegios heredados, sino en la capacidad intelectual como camino hacia el desarrollo personal, el ascenso social y la formación de una comunidad de ciudadanos ilustrados. ${ }^{8}$

Esta investigación se realizó con base en los documentos de archivo hallados en los tomos 106 y 122 del Fondo Ministerio de Instrucción Pública y otros documentos más del Fondo Funcionarios Públicos del Archivo General de la Nación (AGN) ubicado en la ciudad de Bogotá. Esta información, que corresponde en buena parte al cruce de cartas y reportes entre las autoridades provinciales del Ecuador y el ejecutivo central asentado en Bogotá, fue complementada con otras fuentes primarias como informes oficiales, leyes, decretos y los periódicos de la época, además algunas cuantas fuentes secundarias alusivas al tema.

\section{BASE NORMATIVA REPUBLICANA}

El 6 de octubre de 1820 el vicepresidente Santander dictó un decreto que es considerado el primer plan de educación primaria en tiempos republicanos. Allí se reconoció que la instrucción pública era el medio más fácil para que los ciudadanos asimilaran sus derechos y deberes en sociedad, siendo responsabilidad del Estado asegurarles la educación para contribuir a su bienestar y felicidad. Adicionalmente, Santander hizo referencia a una justificación de carácter político al traer a colación la medida adoptada por el Congreso de Angostura que habilitó a partir del año 1830 el derecho al voto únicamente a aquellas personas que supieran leer y escribir. En tal sentido, la educación elemental se constituía en un requisito esencial para hacer valer los derechos ciudadanos en el marco de un gobierno representativo.

7. Carlos Paladines Escudero, comp., El movimiento Ilustrado y la Independencia de Quito (Quito: Fonsal, 2009), 136-159.

8. Rosemarie Terán Najas, “La escolarización de la vida: El esfuerzo de construcción de la modernidad educativa en el Ecuador (1821-1921)" (tesis doctoral, Universidad Nacional de Educación a Distancia, UNED, Madrid, 2015), 20. 
Los maestros debían enseñar a los niños a leer, escribir y contar, y además explicar los dogmas de la religión y de la moral cristiana. Con este decreto, el gobierno abrigaba la esperanza de que las ciencias, las artes, la agricultura y la industria progresaran a medida que el hábito de la lectura, la escritura y la aritmética se hicieran más comunes. ${ }^{9}$ Este precedente normativo abrió el camino para nuevos impulsos a escala regional.

En la Constitución de la República de la Gran Colombia promulgada en 1821 se contemplaron una serie de atribuciones especiales al Congreso para la promoción de la educación pública. ${ }^{10}$ En respuesta a este mandato, el Congreso de Cúcuta expidió la ley del 2 de agosto, en la cual se reiteró que los maestros debían enseñar los preceptos cristianos y los valores ciudadanos. El currículo y el método de enseñanza debían ser uniformes en toda la República, para lo cual había que elaborar cartillas e implementar los reglamentos para la buena gestión administrativa de las escuelas. Asimismo, el poder ejecutivo quedó autorizado para que en las principales ciudades se crearan escuelas pilotos con el método lancasteriano, ${ }^{11}$ para que de allí se fueran difundiendo a todas las provincias.

Por otro lado, la ley dictada el 20 de junio de 1821 dio vía libre para la fundación de casas de educación y colegios públicos en las capitales de provincia, disponiéndose además que en estos planteles debía adecuarse una pieza para instalar una escuela lancasteriana. ${ }^{12}$ Como una fórmula de apoyo económico para la aplicación de esta norma, la ley del 28 de julio dispuso que los fondos, bienes y edificios de los conventos suprimidos fueran invertidos en la educación pública. ${ }^{13}$

Ante las innumerables falencias y vacíos existentes, el Congreso de la República aprobó el 18 de marzo de 1826 una nueva ley con el fin de orga-

9. Alejandro Osorio y Estanislao Vergara, Los encargados de la Secretaría General del Departamento de Cundinamarca presentan a S. E. el General F. de P. Santander, vicepresidente del mismo Departamento, la memoria correspondiente al año de 1820 (Bogotá: Imprenta de Espinosa, 1821), 46.

10. Constitución de la República de Colombia (Rosario de Cúcuta: Bruno Espinosa, Impresor del Gobierno General, 1821), 22.

11. Francisco Sanabria Munévar, “Enseñando mutuamente: una aproximación al método lancasteriano y a su aprobación en Colombia", Revista Historia de la Educación Colombiana 13, n. 13 (2010): 47-76.

12. Las casas de educación combinaban la educación primaria con la secundaria mientras que los colegios ofrecían formación secundaria y superior, aunque entre 1820 y 1826 la mayoría de colegios escasamente contaban con recursos para los cursos de educación secundaria. Evelyn Ahern, "El desarrollo de la educación en Colombia: 1820-1850", Revista Colombiana de Educación, n. ${ }^{\circ} 22-23$ (1991): 30.

13. Luis Horacio López Domínguez, comp., Obra educativa de Santander 1819-1826, vol. I (Bogotá: Biblioteca de la Presidencia de la República, 1990), 43-44. 
nizar el sector educativo. Una de las primeras disposiciones establecía que en todas las parroquias debía haber por lo menos una escuela para niños. El 3 de octubre de este mismo año fue aprobado el Plan de Estudios mediante el cual se dictaron algunas pautas sobre la estructura administrativa de las escuelas, el tipo de instrucción y el pago a maestros. Allí se crearon las juntas curadoras de educación de niños integradas por los jefes políticos municipales y los padres de familia, cuyas funciones eran: elegir el sitio de instalación de la escuela, administrar los fondos y adelantar labores de supervisión. ${ }^{14}$

Con este nuevo marco normativo de 1826 los dirigentes republicanos se mostraron menos empeñados en la religión, en la moralidad y en la salvación de la República pues ahora el énfasis se hizo en el impulso al trabajo útil y el desarrollo económico. ${ }^{15}$ Con el fin de contar con más espacios educativos alternos, el presidente Simón Bolívar reiteró mediante decreto del 27 octubre de 1828 la orden de abrir en todos los conventos regulares escuelas públicas de primeras letras, cuyos maestros serían nominados por los superiores de dichos claustros. No obstante, estos preceptores debían sujetarse al método y reglas dictadas por el gobierno republicano. ${ }^{16}$

Al año siguiente, el Libertador dictó un decreto adicional al Plan de Estudios de 1826. Asume en este, que es su último designio en materia educativa, una postura conservadora al plantear los siguientes puntos: la aceptación de la enseñanza oficial y privada, la flexibilidad del sistema pedagógico, el énfasis en la instrucción religiosa y moral. ${ }^{17}$

La novedad en el proyecto republicano de expansión de la educación pública fue sin lugar a dudas la implementación del método lancasteriano. Este modelo, conocido también con el nombre de mutua instrucción, consistía en que un solo maestro pudiera dirigir a un gran número de alumnos debiendo estos colaborarle activamente en la labor pedagógica.

La implementación de este tipo de escuelas implicó que algunos planteles del antiguo método se adaptaran al nuevo esquema educativo mientras que la mayoría siguió funcionando bajo el modelo tradicional hasta tanto hubiese la oportunidad de capacitar a los maestros.

Habiéndose prevenido en el artículo 15 de la ley del 2 de agosto de 1821 el establecimiento de escuelas normales del método lancasteriano en las

14. Codificación de todas las leyes de Colombia desde el año de 1821, t. VII (Bogotá: Imprenta Nacional, 1924), 228-401.

15. Frank Safford, El ideal de lo práctico. El desafío de formar una élite técnica y empresarial en Colombia (Bogotá: Universidad Nacional / El Áncora, 1989), 80.

16. Archivo General de la Nación (AGN), Fondo Ministerio de Instrucción Pública, t. 106, f. 121 r.

17. Jorge Villalba S. J., "Bolívar y la educación en el Ecuador", Revista de la Universidad Católica del Ecuador, n. ${ }^{\circ}$ 42, año XIII (1985): 149. 
principales ciudades del territorio de la Gran Colombia, se decidió entonces mediante decreto promulgado el 26 de enero de 1822 fundar estos centros de formación en Bogotá y Caracas, y en la ciudad de Quito cuando fuera liberada. Una vez desarrollada esta primera fase, serían expedidas órdenes a los departamentos de Azuay, Ecuador y Guayaquil para que cada una de las provincias bajo su mando enviaran a personas "con talento" a Quito para capacitarlos como maestros del nuevo método. Una vez aprobaran los respectivos exámenes, estos maestros debían regresar a sus provincias con el fin de enseñar el modelo a los candidatos enviados por cada una de las parroquias.

Los gastos de traslado a Quito los debía asumir la renta de propios de cada localidad o, en caso de falta de recursos, el intendente debía tramitar un auxilio de los fondos públicos. Durante el tiempo de capacitación los maestros disfrutarían de un sueldo. Los padres de familia de cada parroquia, interesados en la educación de sus hijos, estaban en la obligación de hacer una pequeña contribución para la alimentación de estos preceptores. ${ }^{18}$

El inglés Joseph Lancaster, el francés Pedro Comettan y el franciscano de origen quiteño fray Sebastián Mora Bermeo fueron los principales difusores del método lancasteriano en el territorio de la Gran Colombia. Lancaster cumplió su misión exclusivamente en Caracas, Comettan en la Nueva Granada y Venezuela, mientras que Mora Bermeo fue el único de ellos en extender su campaña de capacitación a tierras ecuatorianas.

Mora Bermeo fue un activo promotor del nuevo método pues había instalado una escuela lancasteriana en la población de Capacho, en Venezuela, convirtiéndose de este modo en la primera de su tipo en el territorio de la Gran Colombia. ${ }^{19}$ Por orden del vicepresidente Santander, el religioso dejó su curato en Capacho y en octubre de 1821 emprendió viaje hasta Bogotá con el fin de implantar allí el nuevo método. ${ }^{20}$

$\mathrm{Al}$ año siguiente, fue nombrado por el gobierno central como preceptor de la escuela normal en la ciudad de Quito y se le asignó la misión de establecer el nuevo método en los departamentos del sur de la República. ${ }^{21} \mathrm{Al}$ conocer esta noticia el general Antonio José de Sucre, intendente del departamento de Quito, de inmediato ofreció asegurarle al cura un pago mensual

18. Gaceta de Colombia, n. ${ }^{\circ} 27$ (1822): 1.

19. En 1816 este religioso fue enviado preso a España por el general español Pablo Morillo padeciendo allí cinco años de hambre y humillaciones. Tras recobrar su libertad, estudió el novedoso método y regresó para aplicarlo en territorio americano. Ibíd., n. ${ }^{\circ} 29$ : 2. Sobre los cargos que le fueron imputados por las autoridades españolas véase Gregorio Hernández de Alba, comp., "Sumarias de los procesos seguidos contra los clérigos patriotas", Boletín de Historia y Antigüedades XLIX, n. ${ }^{\circ}$ 573-574 (1962): 374-376.

20. AGN, Fondo Ministerio de Instrucción Pública, t. 108, f. 318v.

21. Gaceta de Colombia, n. ${ }^{\circ} 48: 2$. 
de 60 pesos..$^{22}$ En el largo viaje que emprendió Mora Bermeo entre Bogotá y las provincias del sur, aprovechó la ocasión para fundar escuelas en las ciudades de Popayán y Cali.

Tras haber realizado una previa capacitación, Mora Bermeo logró instalar la primera escuela lancasteriana en la ciudad de Quito en mayo de 1825. Funcionaba en una sala amplia con capacidad para 300 niños. La edificación contaba además con una pila de agua y una habitación para el preceptor José Álvarez Romero. El 15 de mayo abrió sus puertas la escuela lancasteriana de la ciudad de Ibarra en una bella e iluminada edificación con capacidad para 120 educandos.

Por esos días, el cura instructor siguió su marcha hacia Otavalo en donde ya contaba con el firme apoyo institucional del gobernador y con un pupilo entrenado en el nuevo modelo de enseñanza. Dejó en claro que no podía esperar más a que los demás cantones enviaran sus profesores porque aún faltaba expandir el método educativo a otras áreas del Ecuador. ${ }^{23}$

En octubre de 1825, Mora Bermeo encontró bastante oposición en la ciudad de Cuenca, al igual que había sucedido en Quito donde había sido objeto de "persecuciones y asechanzas" durante el "dificilísimo" proceso de instalación de la escuela lancasteriana por culpa, según él, de las "hordas de frailes, clérigos y gente vagabunda que de todas clases pululan en esa desgraciada capital”. El secretario del Interior don José Manuel Restrepo aprobó las actuaciones del religioso y valoró el importante servicio que estaba brindando en beneficio de la educación pública de los departamentos del Sur. ${ }^{24}$

El 13 de noviembre de 1825 abrió sus puertas la escuela lancasteriana de la ciudad de Guayaquil bajo el liderazgo de Mora Bermeo. Un total de 120 alumnos iniciaron sus clases aunque el aula tenía capacidad para albergar 100 jóvenes más. Se designó como profesores a José María Bolaños y José Antonio Gómez con el sueldo de 60 pesos mensuales que les serían pagados por la municipalidad. Otros 6 jóvenes fueron instruidos por el fraile franciscano con el propósito de replicar el método lancasteriano en otros cantones. ${ }^{25}$

Tras dos meses de preparativos, el 30 de marzo de 1826 se instaló la escuela de enseñanza mutua en la ciudad de Loja con la presencia de 83 estudiantes, escogiéndose como preceptor al ciudadano Ignacio Alcocer a quien se le asignó un salario anual de 200 pesos. El director Mora Bermeo instruyó en el nuevo método a cuatro ciudadanos más de otros cantones del distrito. En el desarrollo de su gestión, este cura instructor contó en esta ciudad con el apoyo del gobernador, quien le proporcionó una "decente posada" y otros

22. AGN, Fondo Ministerio de Instrucción Pública, t. 106, f. 618r.

23. Ibíd., f. 609r-611r.

24. Ibíd., f. 607r.

25. Gaceta de Colombia, n. ${ }^{\circ}$ 222: 2. 
obsequios más en tanto que la municipalidad le regaló un caballo "lindísimo, enjaezado y adornado de cintas del tricolor nacional, en señal de su eterna gratitud". ${ }^{26}$

En los años posteriores, el religioso se vio agobiado por las penurias económicas, pues desde la ciudad de Quito elevó una carta el 12 de diciembre de 1829, en la cual solicitó al papa Pío VIII permiso para pasar del estado de religioso al estado de sacerdote secular debido a que en su condición de franciscano le era imposible socorrer a su madre anciana. De manera abierta y sincera, exteriorizó su desconsuelo al sentir que no se le había compensado lo justo por sus esmerados servicios a favor de la educación pública:

Así mismo, la suprema autoridad de esta República de Colombia me encomendó erigir escuelas mutuas en casi todo su extenso territorio, y las duras y larguísimas correrías por caminos intransitables, hechas desde el año de 1821 hasta el de 1826, quebrantaron mi constitución física, por lo cual me resulta insoportable llevar la vida del convento sin los auxilios necesarios, por lo demás privado de la retribución que podrían esperar mis merecimientos... ${ }^{27}$

\section{LOGROS Y FRUSTRACIONES EN COBERTURA}

Durante el antiguo régimen colonial el acceso a la educación en Ecuador era muy limitado y allí quedaban excluidos los más desfavorecidos económicamente y los grupos étnicos que ocupaban los últimos peldaños de la jerarquizada estructura social.

Bajo el modelo liberal, los republicanos intentaron cambiar ese desolador panorama y por ello lanzaron una campaña de ampliación del sistema de escuelas públicas. No obstante, en términos reales esa era una meta difícil de alcanzar, especialmente en estos tiempos en que apenas se realizaban ingentes esfuerzos con miras a la recuperación económica después de los estragos provocados por las guerras de Independencia. No hay que perder de vista el hecho de que el distrito sur fue el territorio de la Gran Colombia que más demoró en expulsar a los españoles. Allí el fragor de la guerra fue más acentuado y prolongado.

Sin duda, las principales ciudades y villas marcaron un liderazgo en la difusión de la educación elemental. Aquellas primeras regiones liberadas del dominio español fueron las que alcanzaron mayores progresos pues el

26. AGN, Fondo Funcionarios Públicos, t. 6, f. 231r.

27. Luis Carlos Mantilla, Los Franciscanos en Colombia, t. III, vol. 2 (Bogotá: Ediciones de la Universidad de San Buenaventura, 2000), 534-535. 
conflicto político y militar seguía enraizado en varias regiones del territorio ecuatoriano.

Lo que sí es un hecho incuestionable es que las cifras en cobertura fueron ganando fuerza con el transcurrir de los años, es decir, a medida que terminaba la guerra y Ecuador emprendía su proceso de recuperación económica y de reestructuración administrativa y fiscal.

A continuación, se hará un análisis estadístico de los avances en materia de instalación de escuelas públicas en los departamentos de Ecuador, Azuay y Guayaquil haciendo la aclaración de que la información encontrada impide observar las tendencias con el paso de los años pues los reportes oficiales disponibles presentan algunos vacíos e inconsistencias insalvables.

En 1823 el gobierno central solicitó a todas las provincias del Sur informes detallados sobre el número de escuelas y alumnos. En febrero del año siguiente, el intendente del departamento de Quito, José Félix Valdivieso, lamentó no haber enviado oportunamente el informe por causa del ambiente de convulsión:

La guerra que todo lo absorbe y nos mortifica más de lo que puede significarse, tiene los pueblos en continua angustia y agitación suministrándose con dificultad los urgentes auxilios que demanda S. E. el Libertador sin que sea dable en tal estado llevar a cabo en toda su extensión los designios benéficos del gobierno ni sus disposiciones superiores relativas a la organización interior de estas provincias. Con todo se van recogiendo los datos concernientes al objeto indicado, y tan luego que estén reunidos los necesarios, llenaré las miras del gobierno en esta parte tan interesante..$^{28}$

En 1824, en términos comparativos, se observaban mayores avances en el número de escuelas lancasterianas en la Nueva Granada pues en las provincias de Tunja, Socorro, Pamplona y Casanare estaban instalados 18 planteles de este tipo. ${ }^{29}$

Tal como lo indica el cuadro 1, en marzo de 1825 habían 88 escuelas públicas en el departamento del Ecuador a las que asistían 2.219 estudiantes. En la provincia de Pichincha se registraron 29 planteles, 38 en Imbabura y 21 en Chimborazo: 
Cuadro 1. Número de escuelas instaladas en el departamento del Ecuador, 1825

\begin{tabular}{|c|c|c|}
\hline Provincia & Lugar & n. ${ }^{\circ}$ escuelas \\
\hline \multirow{14}{*}{ Pichincia } & Quito & 8 \\
\hline & La Magdalena & 1 \\
\hline & Chillogallo & 1 \\
\hline & Machachi & 3 \\
\hline & Sangolquí & 1 \\
\hline & Zámbiza & 2 \\
\hline & Guayllabamba & 2 \\
\hline & Yaruquí & 2 \\
\hline & Tumbaco & 1 \\
\hline & Latacunga & 2 \\
\hline & Ambato & 3 \\
\hline & Guaranda & 1 \\
\hline & Guanupa & 1 \\
\hline & Chapaceto & 1 \\
\hline \multirow{20}{*}{ Imbabura } & Ibarra & 4 \\
\hline & Tusa & 4 \\
\hline & Otavalo & 4 \\
\hline & Tulcán & 2 \\
\hline & Cahuasquí & 1 \\
\hline & Caranqui & 1 \\
\hline & Puntal & 1 \\
\hline & Mira & 1 \\
\hline & Salinas & 1 \\
\hline & San Antonio & 4 \\
\hline & Cangahua & 1 \\
\hline & El Ángel & 2 \\
\hline & Urcuquí & 2 \\
\hline & Cotacachi & 2 \\
\hline & Atuntaqui & 3 \\
\hline & San Pablo & 1 \\
\hline & Cayambe & 1 \\
\hline & Tabacundo & 1 \\
\hline & Tocachi & 1 \\
\hline & Malchingui & 1 \\
\hline
\end{tabular}




\begin{tabular}{|c|l|l|}
\hline \multirow{5}{*}{} & Riobamba & 4 \\
\cline { 1 - 2 } & Licto & 1 \\
\cline { 2 - 3 } & Guano & 2 \\
\cline { 2 - 3 } & Chambo & 1 \\
\cline { 2 - 3 } & Pungalá & 1 \\
\cline { 2 - 3 } & Cebadas & 1 \\
\cline { 2 - 3 } & Sicalpa & 1 \\
\cline { 2 - 3 } & Cajabamba & 1 \\
\cline { 2 - 3 } & San Andrés & 1 \\
\cline { 2 - 3 } & Alausí & 1 \\
\cline { 2 - 3 } & San Francisco & 1 \\
\cline { 2 - 3 } & Ambato & 3 \\
\cline { 2 - 3 } & Guaranda & 3 \\
\hline
\end{tabular}

Fuente: Archivo General de la Nación (AGN), Fondo Ministerio de Instrucción Pública, t. 106, f. 668r; Gaceta de Colombia, n. ${ }^{\circ}$ 188: 2.

El siguiente cuadro revela las cifras sobre el número de alumnos según su sexo y condición étnica en cada una de las tres provincias de este departamento. De allí se deduce que los niños blancos eran definitivamente los que tenían más posibilidades de acceso a esta primera escala educativa mientras que la provincia de Imbabura era la que concentraba el mayor porcentaje de escolares indígenas.

Cuadro 2. Número de estudiantes en las provincias del departamento del Ecuador, 1825

\begin{tabular}{|l|c|c|c|c|}
\hline \multicolumn{1}{|c|}{ Provincia } & Niños blancos & Niñas blancas & $\begin{array}{c}\text { Niños } \\
\text { indígenas }\end{array}$ & $\begin{array}{c}\text { Niñas } \\
\text { indígenas }\end{array}$ \\
\hline Pichincha & 588 & 79 & 64 & - \\
\hline Imbabura & 569 & 195 & 107 & 16 \\
\hline Chimborazo & 410 & 143 & 20 & 3 \\
\hline
\end{tabular}

Fuente: AGN, Fondo Ministerio de Instrucción Pública, t. 106, f. 668r, 688r.

Uno de los primeros informes generales con los que se cuenta en el departamento de Azuay es el del cantón de Cuenca elaborado a finales de ene- 
ro de 1823, el cual aparece insertado a continuación. Allí se registraron un total de 424 niños blancos matriculados, 127 niñas blancas, 681 niños indígenas y 232 niñas indígenas.

Cuadro 3. Listado de escuelas y número de estudiantes del cantón de Cuenca, 1823

\begin{tabular}{|l|c|c|c|c|}
\hline \multicolumn{1}{|c|}{ Lugar } & $\begin{array}{c}\text { Niños } \\
\text { blancos }\end{array}$ & $\begin{array}{c}\text { Niñas } \\
\text { blancas }\end{array}$ & $\begin{array}{c}\text { Niños } \\
\text { indígenas }\end{array}$ & $\begin{array}{c}\text { Niñas } \\
\text { indígenas }\end{array}$ \\
\hline Cuenca & 57 & - & - & - \\
\hline Cuenca (convento Santo Domingo) & 81 & - & - & - \\
\hline Cuenca (convento de San Francisco) & 7 & 3 & - & - \\
\hline Cuenca (Convento del Carmen) & 25 & 30 & - & - \\
\hline Cuenca (Convento de Huérfanos) & 10 & - & - & - \\
\hline Valle & - & - & 206 & 121 \\
\hline Baños & 40 & - & 47 & - \\
\hline Cumbe & - & - & 14 & 5 \\
\hline Paccha & - & - & 51 & 13 \\
\hline Sidcay & 72 & 34 & 57 & - \\
\hline Chuquipata & - & - & 116 & 64 \\
\hline Azogues & 98 & 45 & 22 & - \\
\hline Pindilig & - & - & 20 & - \\
\hline Biblián & 26 & 7 & - & - \\
\hline Déleg & - & - & 29 & - \\
\hline San Roque & 8 & 8 & - & - \\
\hline Sayausí & - & - & 15 & - \\
\hline Taday & - & - & 34 & - \\
\hline Nulti & - & - & 46 & 25 \\
\hline Xima & - & - & 24 & 4 \\
\hline
\end{tabular}

Fuente: AGN, Fondo Ministerio de Instrucción Pública, t. 106, f. 706r.

Hacia el mes de febrero de 1825 se elaboró un informe estadístico en el que se revelaron cifras no solo de esta provincia sino de todo el departamento de Azuay (ver cuadro 4). En total, se contabilizaron 1.900 alumnos que recibían clases en 64 establecimientos educativos. Este cuadro, al igual que el siguiente, especifica de manera especial cada una de las clases que recibían los alumnos. 
Cuadro 4. Número de escuelas en el departamento de Azuay, 1825

\begin{tabular}{|c|c|c|c|c|c|c|c|}
\hline Provincia & Cantón & Lugar & $\begin{array}{c}\mathrm{n}^{\circ} \\
\text { Escuelas }\end{array}$ & $\begin{array}{c}\text { Niños } \\
\text { deletreando }\end{array}$ & $\begin{array}{c}\text { Niños } \\
\text { decorando }\end{array}$ & $\begin{array}{c}\text { Niños } \\
\text { escribiendo }\end{array}$ & Total \\
\hline \multirow{19}{*}{ Cuenca } & \multirow{12}{*}{ Cuenca } & Cuenca & 7 & 176 & 43 & 82 & 301 \\
\hline & & Parr. San Roque & 1 & 11 & 29 & 20 & 60 \\
\hline & & Parr. Baños & 1 & 37 & 25 & 13 & 75 \\
\hline & & Parr. Tima & 1 & 9 & 8 & 7 & 24 \\
\hline & & Parr. del Valle & 1 & 35 & 35 & 16 & 86 \\
\hline & & Parr. Sidcay & 1 & 18 & 4 & 2 & 24 \\
\hline & & Parr. Chuquipata & 1 & 12 & 4 & 4 & 20 \\
\hline & & Parr. Taday & 1 & 4 & 6 & 2 & 12 \\
\hline & & Parr. Biblián & 1 & 17 & 11 & 1 & 29 \\
\hline & & Parr. Déleg & 1 & 25 & 13 & 9 & 47 \\
\hline & & Parr. Sayausí & 1 & 10 & 8 & 2 & 20 \\
\hline & & Paccha & 3 & 23 & 17 & 8 & 48 \\
\hline & Azogues & Azogues & 5 & 73 & 28 & 15 & 116 \\
\hline & \multirow{4}{*}{ Gualaceo } & Gualaceo & 3 & 30 & 25 & 15 & 70 \\
\hline & & Paute & 2 & 23 & 22 & 13 & 58 \\
\hline & & Parr. Guachapata & 1 & 9 & 7 & 5 & 21 \\
\hline & & Parr. Sígsig & 1 & 12 & 11 & 7 & 30 \\
\hline & Cañar & Cañar & 2 & 37 & 24 & 39 & 90 \\
\hline & Girón & Parr. Girón & 1 & 19 & 16 & 5 & 40 \\
\hline \multirow{12}{*}{ Loja } & \multirow{5}{*}{ Loja } & Loja & 2 & 56 & 32 & 19 & 127 \\
\hline & & Saraguro & 3 & 13 & 12 & 5 & 30 \\
\hline & & Malacatos & 4 & 22 & 16 & 6 & 44 \\
\hline & & Zumba & 1 & 14 & 19 & 5 & 32 \\
\hline & & Chito & 1 & 5 & 4 & 1 & 10 \\
\hline & Zaruma & Zaruma & 2 & 46 & 39 & 19 & 104 \\
\hline & \multirow{2}{*}{ Catacocha } & Catacocha & 3 & 33 & 25 & 11 & 69 \\
\hline & & Celica & 1 & 3 & 2 & 3 & 8 \\
\hline & \multirow{4}{*}{ Cariamanga } & Cariamanga & 3 & 23 & 18 & 9 & 50 \\
\hline & & Gonzanamá & 5 & 64 & 51 & 39 & 194 \\
\hline & & Sozoranga & 3 & 17 & 15 & 7 & 39 \\
\hline & & Amaluza & 1 & 8 & 8 & 6 & 22 \\
\hline
\end{tabular}

Fuente: AGN, Fondo Ministerio de Instrucción Pública, t. 106, f. 635r. 
En julio del año siguiente, escasamente se registraba en este mismo departamento una escuela lancasteriana ubicada en la ciudad de Loja mientras que el número de educandos se había elevado a $1.271 .^{30}$

Aunque había sido el primer territorio liberado del dominio español, varios meses se demoró la intendencia de Guayaquil en presentar su informe debido a la negligencia de los jueces políticos locales. Finalmente, en abril de 1824 se enviaron a la secretaría del Interior las cifras que daban cuenta de cuatro planteles en Santa Helena, dos en Montecristi y otros dos en la capital del departamento, Guayaquil. Asimismo había sendas escuelas en las poblaciones de Samborondón, Yaguachi, Babahoyo, Caracol, Pueblo Viejo, Baba, Estero de Vinces, Daule, Soledad, Colimes, Portoviejo, Limón, Mocora, Pachinche, Bonce, Río-chico, Pimpiguasí, Guayabo, Alonso Pérez, Pievasa, Pichota, Pasaje, Jipijapa, Lodana, Pajan, Palma, Zapotal, Colimes, Charapotó, Chone, Canoa, Morro, Chanduy, Colonche, Machala y Balao. ${ }^{31}$

Hacia el mes de agosto del año siguiente fue presentado un informe mucho más completo de este departamento. En el cuadro que aparece a continuación se puede observar cómo se registraron un total de 3.154 estudiantes, obteniéndose los mayores logros en la clase de lectura, en segundo orden la clase de escritura y por último la clase de matemáticas. Guayaquil y Manabí fueron los dos cantones que concentraban el mayor número de educandos, aproximadamente el $74 \%$ del total.

Cuadro 5. Número de escolares en las provincias del departamento de Guayaquil, agosto de 1825

\begin{tabular}{|c|l|r|r|r|r|}
\hline Provincia & Cantón & $\begin{array}{c}\text { Jóvenes } \\
\text { leyendo }\end{array}$ & $\begin{array}{c}\text { Jóvenes } \\
\text { escribiendo }\end{array}$ & $\begin{array}{c}\text { Jóvenes en } \\
\text { aritmética }\end{array}$ & Totales \\
\hline \multirow{4}{*}{ Guayaquil } & Guayaquil & 523 & 409 & 84 & 1.016 \\
\cline { 2 - 6 } & Daule & 108 & 78 & 7 & 193 \\
\cline { 2 - 6 } & Babahoyo & 40 & 12 & 10 & 62 \\
\cline { 2 - 6 } & Machala & 40 & 6 & 4 & 50 \\
\cline { 2 - 6 } & Santa Helena & 427 & 71 & 19 & 517 \\
\hline Manabí & Manabí & 920 & 314 & 82 & 1.316 \\
\hline Totales & & 2.058 & 890 & 206 & 3.154 \\
\hline
\end{tabular}

Fuente: AGN, Fondo Ministerio de Instrucción Pública, t. 122, f. 278r; Gaceta de Colombia, n. ${ }^{\circ}$ 219: 3. 
En cifras globales, recopilando las estadísticas de los tres departamentos para el año de 1825, se puede concluir que los mayores índices de cobertura se alcanzaron en Guayaquil, obteniéndose en todo el territorio del Ecuador un total de 7.273 alumnos.

Según datos suministrados a nivel oficial, a mediados de 1827 existían en el territorio de la Gran Colombia 52 escuelas lancasterianas con 3.509 niños y 434 planteles del método antiguo con 16.200 estudiantes. En todas las provincias de la República había por lo menos una o dos escuelas de este tipo. ${ }^{32}$ Así las cosas, para esta fecha faltaba mucho trecho para lograr una uniformidad en el método que era uno de los anhelos principales del gobierno.

En términos generales, la desidia de los funcionarios públicos, la desconfianza frente al método lancasteriano, la indiferencia de los padres y la falta de una acción coordinada, fueron factores que entorpecieron el proceso de apertura de escuelas.

\section{LA EDUCACIÓN DEL BELLO SEXO Y DE LOS INDÍGENAS}

Desde tiempos coloniales había primado el énfasis en la instrucción para varones. Por eso, una de las preocupaciones del naciente gobierno republicano fue diseñar una política educativa más incluyente que les permitiera a las mujeres desarrollar un papel más activo en la sociedad.

No obstante, se presentaba una situación ambigua por cuanto se promovía el acceso de las mujeres a la educación pese a ser aún un grupo excluido de la ciudadanía. En ese sentido, tal como lo plantea la historiadora Rosemarie Terán Najas: "la educación también fue invocada como un elemento de integración y de unificación de toda la población alrededor de nuevos valores, símbolos y sociabilidades que buscaban homogeneizar para contrarrestar la gran heterogeneidad preexistente". ${ }^{33}$

Para el presidente Simón Bolívar, la formación de las niñas era la base de la educación de la familia. ${ }^{34}$ El vicepresidente Santander también había reflexionado desde un comienzo sobre la conveniencia de centrar más la atención en la ilustración del sexo femenino. Así se lo hizo saber al secretario de Guerra en una carta fechada el 2 de mayo de $1820 .{ }^{35}$

32. El Constitucional, n. ${ }^{\circ} 151$ (1827): 1.

33. Terán Najas, "La escolarización de la vida...", 26.

34. Ana Carmen Neissa de Mantilla, La evolución del pensamiento educativo de Simón Bolívar. Principios vigentes en los modelos pedagógicos del tercer milenio (Bogotá: Gente Nueva, 2005), 113.

35. Roberto Cortázar, comp., Cartas y Mensajes del General Francisco de Paula Santander, vol. 3 (Bogotá: Academia Colombiana de Historia, 1956), 136. 
El 28 de julio de 1821 el Congreso de la República aprobó la fundación de escuelas en los conventos de religiosas. ${ }^{36}$ La medida quedó supeditada a una mayor intervención estatal y, para ello, el poder ejecutivo instó a los arzobispos y obispos a cooperar con denuedo para lo cual se debían acordar mancomunadamente los parámetros para el funcionamiento, el reglamento y el manejo administrativo de estos establecimientos en servicio "a Dios y a la Patria" ${ }^{37}$ El gobierno, entre tanto, reiteró su compromiso por la protección e impulso de la educación de las niñas y jóvenes para beneficio de la moral pública y la religión.

En otra ley aprobada ese mismo día por el máximo órgano legislativo, se abrió una nueva alternativa de apoyo para las escuelas de niñas al estipularse la supresión de los conventos de regulares con menos de ocho religiosos, cuyos edificios y haberes serían destinados preferentemente a la educación pública. $^{38}$

De manera paralela, en la ley del 2 de agosto dirigida a la fundación de escuelas públicas para niños, se incluyó en el artículo $17^{\circ}$ una serie de disposiciones para el fomento de la educación femenina a través de una fórmula que combinaba la iniciativa ciudadana y el apoyo oficial a escala local. Este asunto fue catalogado por los legisladores como de suma importancia "para la felicidad pública". Le fue concedida la facultad al poder ejecutivo para fundar estas escuelas bajo el patrocinio de los vecinos o por otras instancias en las cabeceras de los cantones y demás parroquias en que fuere posible. En estos establecimientos las pequeñas debían aprender los principios morales y religiosos pero además debían cultivar el arte tradicional de coser y bordar. Estas escuelas quedaban regladas bajo los mismos parámetros que las escuelas de niños y era obligación del gobierno proponer al Congreso de la República las alternativas para incentivar la fundación de estos planteles y garantizar su dotación. ${ }^{39}$

Aún con las intenciones y avances normativos que se acaban de describir, todo indica que las oportunidades de acceso a la educación básica seguían padeciendo un profundo desbalance en materia de género. En noviembre de 1824, José Félix Valdivieso, intendente del departamento del Ecuador, solicitó al secretario del Interior instalar en la ciudad de Quito una escuela en la que pudieran educarse las niñas, para lo cual propuso adecuar como sede el beaterio que en esos momentos funcionaba como asilo para las mujeres "con

36. En Quito funcionaban los monasterios de La Concepción, Santa Catalina de Siena, Santa Clara, El Carmen Alto y el de la Santísima Trinidad.

37. Actas del Congreso de Cúcuta 1821, vol. II (Bogotá: Biblioteca de la Presidencia de la República, 1990), 124.

38. Gaceta de la ciudad de Bogotá, n. ${ }^{\circ} 125$ (1821): 403.

39. Actas del Congreso de Cúcuta..., 160. 
una vida descarriada y entregada a los placeres mundanos". El propósito era fundar esta escuela para educar las jóvenes "según los principios de una sabia y religiosa disciplina".

La respuesta del gobierno central era que no se podía alterar el destino de las rentas aplicadas al mencionado beaterio que estaba a cargo de la orden de Nuestra Señora de las Mercedes, razón por la cual se envió la propuesta para ser analizada por la Cámara de Representantes. Allí la comisión eclesiástica consideró viable la propuesta pero sin que el beaterio dejara de cumplir su "loable" función que era considerada no menos importante. El caso pasó también a estudio de la comisión de policía, instancia que estuvo de acuerdo con el concepto anterior y, por ello, se pidió un informe sobre las finanzas y el estado de la edificación con miras a concretar la posibilidad de abrir un espacio en beneficio de la instrucción del bello sexo en esa ciudad. ${ }^{40}$

Una propuesta similar elevó a finales del año siguiente la junta provincial de Pichincha al gobierno central en relación con la idea de instalar una escuela de niñas con los fondos del beaterio, destinándose una manzana de las dos que poseía el monasterio de la Concepción. El ejecutivo ordenó trasladar este asunto al Congreso para que diera su dictamen sobre este proceso de conversión de recursos. ${ }^{41}$ Por estos días, el gobernador del Obispado informó al intendente de Quito que finalmente había podido abrir escuela en el convento de La Concepción en donde impartían clase dos maestras que recibían una corta gratificación de los padres de las educandas. ${ }^{42}$

En cuanto a cifras concretas, el cuadro 3 permite ver cómo hacia el año de 1823 en el cantón de Cuenca la proporción de niñas matriculadas era notoriamente inferior a la del sexo opuesto. Igual tendencia se registra en 1825 en el departamento del Ecuador (ver cuadro 2) en donde la presencia femenina en las escuelas llegaba al 13,6\%. Según un informe publicado en la prensa oficial en el mes de abril, en este territorio se contabilizaban un total 22 escuelas para niñas. ${ }^{43}$

A finales de 1828, las damas de Guayaquil asociadas en la Junta Curadora para la educación de las niñas trabajaron arduamente para concretar el establecimiento de escuela en esta ciudad de acuerdo con lo estipulado en la ley del 10 de marzo de 1826. El intendente se sumó a este propósito con el aporte de 912 pesos correspondientes al producto del remate anual del juego público de lotería. Ante la falta de local, este alto funcionario ofreció las instalaciones del suprimido convento de San Agustín ubicado en una de las esquinas de la plaza mayor. Este apoyo fue apreciado por la Junta en aras del equilibrio

40. AGN, Fondo Ministerio de Instrucción Pública, t. 122, ff. 543r-561v.

41. López Domínguez, Obra educativa de Santander..., 297.

42. Villalba, "Bolívar y la educación en el Ecuador", 161.

43. Gaceta de Colombia, n. ${ }^{\circ}$ 185: 2. 
por cuanto la mayor parte de los bienes de este suprimido claustro estaban destinados al colegio de varones. ${ }^{44}$

En la conquista y en la Colonia, la educación de los indígenas fue muy escasa y se enfocó básicamente en la gramática y en la disciplina religiosa dirigida a extirpar la idolatría. ${ }^{45}$ Con la llegada del período republicano, se aunaron esfuerzos tendientes a extender los beneficios de la educación elemental a este sector de la sociedad. Mediante decreto promulgado el 20 de mayo de 1820, el presidente Simón Bolívar resolvió revivir la norma que ordenaba destinar los productos de los arrendamientos de los resguardos al pago de los maestros de las escuelas instaladas en cada pueblo. Se dispuso además que todos los indígenas entre 4 y 14 años debían asistir a la escuela en donde se les enseñarían las primeras letras, la aritmética, los fundamentos de la religión católica, los derechos y deberes del hombre y del ciudadano. ${ }^{46}$

En el decreto que emitiera cinco meses más tarde el vicepresidente Santander reiteró las antedichas medidas instauradas por Bolívar e hizo un llamado especial a los gobernadores, jueces políticos y párrocos a fin de que garantizaran la instrucción a los nativos. Al año siguiente fue sancionada la ley del 2 de agosto de 1821 que reiteró que las escuelas debían ser dotadas con el producto de los arrendamientos del sobrante de los resguardos y, adicionalmente, se recordó a los blancos y mestizos residentes en dichos espacios que debían aportar también para el sostenimiento del plantel ${ }^{47}$

A pesar de la buena intención de estas tempranas leyes, en realidad surgieron muchas complicaciones en la consecución del terreno para la sede educativa y en la búsqueda de recursos para el pago de los maestros. No hay que pasar por desapercibido el panorama demográfico del denominado territorio del Distrito del Sur, en lo que hoy corresponde al Ecuador, en donde el porcentaje de la población indígena fue mucho más acentuado que en la Nueva Granada y en Venezuela. ${ }^{48}$

44. AGN, Fondo Ministerio de Instrucción Pública, t. 106r, f. 611r.

45. Alberto Martínez Boom, Escuela, maestro y métodos en Colombia 1750-1820 (Bogotá: Universidad Pedagógica Nacional, 1986), 46.

46. Luis Horacio López Domínguez, comp., De Boyacá a Cúcuta. Memoria Administrativa, 1819-1821 (Bogotá: Biblioteca de la Presidencia de la República, 1990), 189-191.

47. Felipe Osorio Racines, Decretos del General Santander 1819-1821 (Bogotá: Universidad Nacional, 1969), 155-159.

48. Según el censo de población adelantado entre 1778 y 1781 en la Audiencia de Quito por orden del presidente don Juan Joseph de Villalengua, la comunidad indígena representaba la mayoría, con el $63 \%$; los blancos el $26 \%$ y otras castas el $11 \%$. Entre tanto, para el censo demográfico realizado por esos mismos años en territorio neogranadino, las cifras indicaban que la mayor parte eran mestizos y los indígenas eran apenas una quinta parte del total de la población. Guillermo Bustos Lozano, "La redefinición del orden colonial". En Manual de Historia del Ecuador. Épocas Aborigen y Colonial, Independencia (Quito: 
Aunque no se cuentan con cifras consolidadas para elaborar un análisis sistemático, las cifras contenidas en el cuadro 3 alusivas al territorio del departamento del Ecuador en 1825 indican que el número de alumnos indígenas escasamente llegó a representar la décima parte del total de matriculados. Bastante notoria fue también la relación de género al interior de la comunidad educativa indígena pues las niñas no superaban el $20 \%$.

En últimas, este tardío reconocimiento de los derechos educativos de las mujeres y de los indígenas generó un retraso en las oportunidades de ascenso social y económico para los sectores afectados, aplazándose por mucho más tiempo las posibilidades de escalar en los espacios de poder y de decisión política, con lo cual se aumentó indefectiblemente la brecha de desarrollo formativo en estos primeros años de vida republicana.

\section{LAS CEREMONIAS EDUCATIVAS Y EL SENTIMIENTO PATRIO}

En el marco del proceso de Independencia, tanto los patriotas como los realistas recurrieron a las celebraciones políticas como espacios de reafirmación simbólica y para revalidar las lealtades en medio de una intensa confrontación ideológica y acérrimos antagonismos políticos. Estos eventos hacían parte del proceso de legitimidad y como fórmula para sentar las bases de la estructura política triunfante. ${ }^{49}$

Algunas fundaciones de escuelas y colegios públicos se realizaron en medio de actos solemnes y en determinados casos coincidieron con fechas de celebraciones patrióticas o religiosas, con lo cual se pretendía imprimir mayor realce a estos acontecimientos y al mismo tiempo enviar un mensaje de estímulo a otras localidades con el fin de que se animaran a crear este tipo de establecimientos educativos.

En estos tiempos en que se cimentaban las bases de una Patria libre y soberana, la intención de fondo era acudir a la protección divina y entronizar en la comunidad las virtudes de los principios republicanos, asociándolos con el impulso de la cultura y la educación dentro de un nuevo modelo de nación. A pesar de la escasez de recursos en estos tiempos de tensión política y crisis económica, los vecinos y las autoridades políticas y eclesiásticas rea-

Universidad Andina Simón Bolívar, Sede Ecuador / Corporación Editora Nacional, 2008), 80; Hermes Tovar Pinzón, Convocatoria al poder del número (Santa Fe de Bogotá: Archivo General de la Nación, 1994), 86-88.

49. Roger Pita Pico, “La función política de las celebraciones públicas durante el proceso de Independencia de Colombia: En la búsqueda de la legitimidad y la lealtad", Revista Historia y Sociedad, n. ${ }^{\circ} 3$ (2012): 178, 200. 
lizaron grandes sacrificios con tal de generar un impacto positivo con estas ceremonias.

El día 4 de mayo de 1825 fue inaugurada la escuela lancasteriana de Quito con asistencia numerosa de ciudadanos que aplaudieron y agradecieron al gobierno central, al intendente del Departamento y al alcalde Luis Salvador por el apoyo económico y logístico al proyecto educativo en marcha. Ese día, según el cura Mora Bermeo, se reconciliaron los acérrimos enemigos que consideraban al nuevo método como una afrenta a los principios de la religión. En el acto los estudiantes presentaron un examen académico en el que demostraron los conocimientos adquiridos en tan solo unos pocos días de clases y se aprovechó la ocasión para reconocer la solvencia académica y dedicación del profesor José Álvarez Romero, a quien se le calificó como "sujeto patriota de bastante instrucción y bien opinado". De igual modo, se reconoció el gran esfuerzo hecho por el cura Mora Bermeo a pesar de estar afectada su salud.

Al cabo de 11 días abrió sus puertas "con no menos aplausos" la escuela de Ibarra, resaltándose la loable gestión adelantada por el gobernador y el juez político de ese cantón, el ciudadano Joaquín Gómez de la Torre. ${ }^{50}$

Con gran entusiasmo fue celebrada también la apertura de la escuela lancasteriana de la ciudad de Guayaquil el día 13 de noviembre de 1825. Los 120 niños agrupados en 8 clases dieron muestras de sus adelantos en lectura, escritura y aritmética en presencia de un numeroso concurso de gentes y de la primera autoridad del Departamento. En este acto se exaltó la colaboración permanente de las autoridades locales en el proceso de organización de este plantel. ${ }^{51}$

Un gran acto presenciaron los ciudadanos de Loja el 30 de marzo de 1826 para celebrar la inauguración de su escuela de enseñanza mutua. Allí concurrieron el rector del colegio de Loja, el cura Joaquín Añasco, las autoridades eclesiásticas y las autoridades civiles encabezadas por el cabildo y por el gobernador provincial Manuel Carrión. El público en pleno y, en especial, los detractores del nuevo modelo pedagógico pudieron presenciar en vivo los avances de los alumnos a tan solo mes y medio de haber iniciado las clases con la escritura y lectura de algunas cortas frases y operaciones básicas de aritmética.

La sala capitular agradeció al Libertador Simón Bolívar, a las autoridades departamentales y especialmente al cura Mora Bermeo por su liderazgo, asignándole un premio de 100 pesos a manera de compensación por su esmero en este proyecto educativo. El certamen culminó con un emotivo dis-

50. AGN, Fondo Ministerio de Instrucción Pública, t. 106, f. 609r.

51. Gaceta de Colombia, n. ${ }^{\circ}$ 222: 2. 
curso del padre Mora Bermeo, en el cual hizo un elogio a la libertad y realizó una férrea defensa de las bondades del método de Lancaster:

Señores, hoy se ha plantado en los confines australes de la República la pieza angular de una educación verdaderamente sabia, liberal y común. Ya tenéis pues, delante de vuestros ojos, la escuela de enseñanza mutua, fruto digno de los cuidados del supremo gobierno y de los paternales desvelos, celo y afanes de los ilustres jefes de la provincia y municipalidad. En medio del dolor que me asiste viendo que por todas partes, a proporción que difundo y empiezan a disfrutar y conocer sus ventajas, no faltan gentes que sin saber manejar la crítica han hecho creer a otras que semejante establecimiento tiende a la impiedad y depravación, tengo al mismo tiempo la inexplicable satisfacción de presentar este primer certamen en ella para que todo el que quiera analice sus lecciones y el modo inocente en que se reúnen a aprenderlas los niños. ${ }^{52}$

Para comprobar en el tiempo el rendimiento académico de los estudiantes, se organizaron certámenes públicos en las escuelas de primeras letras. Estas fueron también unas ceremonias de hondo carácter político pues solían asistir las principales autoridades de cada ciudad y se aprovechaba además la ocasión para enaltecer el sentimiento patrio y la influencia de la educación en la formación de la República.

La idea era que la comunidad pudiera evidenciar de manera directa las virtudes del nuevo modelo de educación pública y a la vez sirviera de estímulo para apoyar iniciativas de esta naturaleza. Dicho en otras palabras, eran actos de "apropiación y visibilización pública de los procesos de formación de los futuros ciudadanos", un factor clave de integración política con miras a consolidar el proyecto republicano, con lo cual se ampliaba el sentido de lo público y de lo cívico. ${ }^{53}$

Otras actividades literarias y culturales se desarrollaron para complementar los certámenes académicos centrales, los cuales contaron con una gran difusión en la prensa de la época para llevar el mensaje de progreso educativo a regiones apartadas.

Estas celebraciones fueron además una ocasión propicia para rendir homenaje a los héroes de la Patria y a los funcionarios y benefactores, cuya influencia había sido decisiva en el establecimiento y adelanto de los planteles. Fue entonces común que dichos certámenes académicos se dedicaran a estos gestores de la República y de la educación pública, una fórmula que resultaba útil para ellos en torno a ganar legitimidad e incrementar su prestigio dentro del nuevo orden social y político.

52. AGN, Fondo Funcionarios Públicos, t. 6, f. 232r.

53. Terán Najas, "La escolarización de la vida...", 29-30. 
A mediados de 1824 los alumnos de la escuela lancasteriana de la ciudad de Cuenca presentaron un examen en lectura, escritura, aritmética, doctrina cristiana, nociones generales de geometría, principios de política, virtudes sociales y obligaciones a la Patria e igualmente hicieron un recuento del justo triunfo de la independencia, según las disertaciones contenidas en el catecismo del Padre Juan Fernández de Sotomayor. ${ }^{54}$ En las páginas de la Gaceta de Colombia se puso de presente el beneficio e impacto de este tipo de eventos académicos:

Tales son las primicias que la juventud [...] ha ofrecido al público como el fruto de sus primeras tareas: ellas anuncian bienes tan preciosos a Colombia que los amantes de su prosperidad no pueden calcular sin sentimientos de placer. Las autoridades respectivas y ciudadanas de todas clases que a competencia concurrieron a solemnizar estos actos, admiraban con satisfacción los progresos de la literatura en la República y beneficencia de un gobierno bajo cuyos auspicios las luces hacen adelantamientos semejantes..$^{55}$

El día 24 de enero de 1826 el intendente del departamento del Ecuador, José Félix Valdivieso, dio reporte al secretario del Interior, don José Manuel Restrepo, sobre el certamen académico presentado por los niños de la escuela lancasteriana de la ciudad de Quito. Un total de 163 infantes dieron respuesta a un examen público en el que "admirablemente" realizaron algunos escritos sobre la primera parte del catecismo de Fleury y de los primeros rudimentos de aritmética y gramática castellana. Estas fueron las palabras de satisfacción de Valdivieso que fueron publicadas en la prensa oficial:

Sus progresos corresponden felizmente al dichoso método que se ha adoptado por el gobierno para que los tiernos hijos del Ecuador sean útiles a la patria [...] Las corporaciones y más vecinos que asistieron al acto manifestaban grande regocijo de oír la destreza con que satisfacían a sus preguntas, dando los más sinceros agradecimientos al gobierno supremo por el interés que ha tomado en el progreso de las luces. Sírvase vuestra señoría poner estos particulares en conocimiento de su excelencia [el vicepresidente Santander] para su satisfacción. ${ }^{56}$

La señora Teresa Suárez de Aguilar, directora de una escuela particular de niñas en la ciudad de Guayaquil, organizó en la noche del 4 de febrero de este mismo año un certamen académico en obsequio al vicepresidente Santander. Catorce jóvenes de muy tierna edad se examinaron mutuamente en

54. Juan Fernández de Sotomayor y Picón, Catecismo o instrucción popular (Bogotá: En la Imprenta del C. B. E., 1820): 1-16. Tomado de BNC, Fondo Quijano, t. 426, pieza 1.

55. Gaceta de Colombia, n. ${ }^{\circ}$ 151: 3.

56. Ibíd., n. ${ }^{\circ}$ 232: 3. 
los principios de religión, máximas de moral y educación, y geografía física y política de Colombia. Según se dijo: "los espectadores quedaron completamente satisfechos de la instrucción de las niñas y del celo y aptitud de la directora, muy digna por esta circunstancia y por ser viuda de un oficial fusilado por orden de [comandante español Pablo] Morillo, de la protección del gobierno y del público". ${ }^{57}$

\section{LA FINANCIACIÓN EN TIEMPOS DE CRISIS}

Las fuentes de financiación de la educación pública fueron uno de los temas más álgidos de discusión durante la naciente República. Varias opciones de recursos públicos, privados y mixtos fueron analizadas al interior del gobierno y del Congreso ante el déficit de las arcas públicas, los elevados gastos consumados en la guerra y el estado de desaceleración económica. ${ }^{58}$ Los saqueos, los embargos, los donativos, las contribuciones forzosas y la ruina provocada por la confrontación militar en el proceso de Independencia, eran factores que habían generado un impacto generalizado.

En su decreto del 6 de octubre de 1820, el vicepresidente Santander ordenó que las ciudades y villas con rentas de propios debían establecer una escuela pública. Para tal efecto, los gobernadores políticos obligarían a los cabildos para que "inmediatamente y sin excusa" procedieran a realizar esta fundación.

La ley del 2 de agosto de 1821 ordenó que en todas las ciudades, villas y parroquias de más de 100 vecinos debía haber por lo menos una escuela de primeras letras. Las ciudades y villas sufragarían los gastos de dotación con los recursos de las rentas de propios, pero, allí donde estos recursos fueren insuficientes y, en las parroquias, había que recurrir a la solidaridad de los vecinos, comprometiéndose voluntariamente a efectuar los pagos mensuales. Si de este modo no se cubría la cantidad requerida para la escuela, las autoridades locales se encargarían de hacer un repartimiento "justo y moderado" teniendo en cuenta el patrimonio y número de hijos de cada vecino cabeza de familia. Esta lista cobijaba a los solteros y exceptuaba a los pobres, cuyos hijos accederían gratuitamente a la educación. Era también deber de los vecinos conseguir la sede para la escuela y los útiles indispensables para el trabajo académico.

57. Ibíd., n. ${ }^{\circ}$ 235: 2.

58. Se sabe por lo menos que en el año fiscal de 1825-1826, aproximadamente las tres cuartas partes de los gastos del Estado grancolombiano estaban enfocadas hacia el estamento militar. David Bushnell, El Régimen de Santander en la Gran Colombia (Bogotá: El Áncora, 1985), 122. 
Cabe precisar que los gastos para el establecimiento de las escuelas lancasterianas eran muy superiores en comparación con los planteles del antiguo método. Para las primeras existían una serie de requisitos estipulados en el manual, considerados como indispensables para el nuevo modelo de enseñanza: especificaciones en el tamaño y forma del salón de clases, bancos y mesas diseñadas especialmente, rueda del alfabeto, telégrafos, gavetas para lápices, tablas de lecturas, distintivos de clase, punteros, campanillas, silbatos y reloj. ${ }^{59}$

Constantes fueron las quejas sobre la falta de presupuesto que truncaban los propósitos planteados en materia de educación básica. Era claro que el Estado no estaba en capacidad de cubrir todas las necesidades a nivel provincial y local. Ante la crisis fiscal imperante, los impuestos, los estancos, el arriendo de tierras comunales y las donaciones fueron fuentes de recursos de gran apoyo para el desarrollo de la educación básica.

Otra opción altamente estimada por el gobierno fue el de las donaciones, las cuales fueron además una muestra de la solidaridad de la comunidad en procura de la causa de la educación pública. Esta colaboración de la comunidad se enmarcaba dentro del modelo liberal que contemplaba la posibilidad de la contribución económica privada. En cierta manera, este involucramiento de la acción privada en el proceso de consolidación del sistema educativo permitió el fortalecimiento del sentido de lo público.

En medio de la crisis económica imperante, en marzo de 1825 el presbítero Domingo Benítez cedió voluntariamente 136 pesos 4 reales para los gastos de la escuela lancasteriana que se estaba estableciendo en la ciudad de Ibarra. Eusebio Borrero, gobernador y comandante de armas de la provincia de Imbabura, exaltó la "patriótica generosidad" de este cura y puso de relieve su apoyo incondicional a la causa de la libertad desde el año de $1809 .{ }^{60}$

Sobre algunos de los informes presentados a nivel provincial, es posible realizar algunas conclusiones sobre el tipo de financiación existente. De las 20 escuelas registradas en el cantón de Cuenca en enero de 1823, 15 de ellas se mantenían con el apoyo de los vecinos, 4 con los recursos de los conventos y 1 con fondos del cabildo municipal. ${ }^{61}$

En el informe presentado en marzo de 1825 sobre el estado de las escuelas fundadas en el departamento del Ecuador (ver cuadro n. ${ }^{\circ} 6$ ), se puede observar cómo el aporte mancomunado de los vecinos era la alternativa más usual a la hora de financiar las escuelas. La segunda categoría, "gratis", corresponde a los maestros que de manera filantrópica desarrollaban su tarea pedagógica sin exigir un salario.

59. Manual del sistema de enseñanza mutua aplicado a las escuelas primarias en los niños (Bogotá: Impreso por S. S. Fox, 1826), 112.

60. Villalba, "Bolívar y la educación en el Ecuador", 156.

61. AGN, Fondo Ministerio de Instrucción Pública, t. 106, f. 706r. 
Cuadro 6. Fuentes de financiamiento de las escuelas del departamento del Ecuador, 1825

\begin{tabular}{|l|c|}
\hline \multicolumn{1}{|c|}{ Fuentes de financiamiento } & n. ${ }^{\circ}$ escuelas \\
\hline Padres de los alumnos & 38 \\
\hline Gratis & 5 \\
\hline Conventos & 4 \\
\hline Arrendamiento de tierras & 4 \\
\hline Caridad del cura & 2 \\
\hline Recursos municipales & 1 \\
\hline Temporalidades & 1 \\
\hline Vecinos y arriendo de tierras & 1 \\
\hline Tributos, cura y censo & 1 \\
\hline
\end{tabular}

Fuente: AGN, Fondo Ministerio de Instrucción Pública, t. 106, f. 668r, 688r.

Una nueva alternativa surgió a raíz de la ley del 28 de julio de 1821 en la cual se dispuso que los fondos, bienes y edificios de los conventos suprimidos fueran invertidos en la educación pública. En septiembre de 1827 el poder ejecutivo autorizó destinar los bienes del convento suprimido de San Francisco de la villa de Zaruma para el beneficio de la escuela pública de esta localidad. ${ }^{62}$

Desde que se estableció la escuela lancasteriana de Quito, se le pagaba al maestro 60 pesos mensuales del tesoro público. Pero, en noviembre de 1829, el prefecto del departamento del Ecuador solicitó al presidente Simón Bolívar que, en vista de la extrema decadencia de fondos que implicaba desatender asuntos de grave consideración, se estudiara la posibilidad de satisfacer este pago del fondo de ramos municipales, conforme lo había contemplado la ley del 11 de abril de $1825 .^{63}$

El proyecto educativo republicano de esta década del 20 estuvo acompañado en algunas ciudades por asociaciones de notables inspirados en el pensamiento republicano y con fuertes convicciones patrióticas. Allí participaron personas distinguidas y altos funcionarios con el objetivo de contribuir al desarrollo económico pero también al fomento de la educación pública.

Esta sociabilidad se constituyó en un valioso apoyo al proyecto educativo oficial en vista de la debilidad económica e institucional de un Estado

62. AGN, Fondo Ministerio de Instrucción Pública, t. 106, f. 646r.

63. Ibíd., t. 106, f. 661r. 
que se veía incapaz de cumplir las ambiciosas metas trazadas. A través de esas asociaciones se lograron valiosos aportes en la adecuación de escuelas, en la capacitación y pago de preceptores y en la donación de útiles escolares y material didáctico. De alguna manera, estas sociedades voluntarias ayudaron a disminuir la presión ejercida sobre los cabildos, instancias que tenían la responsabilidad de organizar recolectas entre la comunidad. ${ }^{64}$

En mayo de 1823, mientras Mora Bermeo instalaba una escuela en Popayán, teniendo como mira los territorios del Sur, la Sociedad Económica de Quito adelantó gestiones dirigidas a conseguir útiles escolares para la escuela del nuevo método lancasteriano que sería fundada en esta ciudad. A mediados del año siguiente, esta misma Sociedad mandó imprimir varios manuales para el uso de las escuelas, gestión que le mereció elogios y agradecimientos en la prensa oficial. ${ }^{65}$

\section{Maestros Y DOTACión}

En estos primeros años de vida republicana fue una preocupación constante la falta de profesores y la deficiente preparación. Los incipientes niveles educativos de la sociedad ecuatoriana ofrecían muy pocos candidatos a ocupar las vacantes de maestros, motivo por el cual en muchos casos no había más opción que seguir recurriendo a los religiosos que venían cumpliendo esa función. No era entonces extraño que las autoridades civiles solicitaran a las jerarquías eclesiásticas la disponibilidad de alguno de sus miembros para vincularlos a las tareas pedagógicas.

Muy realista y sintomática de esta situación fue la opinión expresada por el cabildo de Cuenca en enero de 1823 sobre el estado de las escuelas de este cantón: "Aunque los maestros no son adornados de las calidades necesarias por la general escasez de hombres aptos, conceptúa este ayuntamiento que mediante su vigilancia y examen mensual se perfeccionarán en la instrucción que se les dé". ${ }^{66}$

Pero, si había dificultades para ubicar preceptores bajo el método antiguo, mucho más difícil fue conseguir maestros capacitados con el nuevo modelo lancasteriano pues, para ello, era necesario un proceso previo de capacitación.

64. Meri L. Clark, “Conflictos entre el Estado y las élites locales sobre la educación colombiana durante las décadas de 1820 y 1830", Historia Crítica, n. ${ }^{\circ} 34$ (2007): 58.

65. AGN, Fondo Ministerio de Instrucción Pública, t. 106, ff. 605r, 709r.

66. Ibíd., f. 708r. 
Además de adecuar la sede de la escuela y costear el pago del maestro, debían adelantarse las gestiones con miras a la consecución de útiles escolares. El gobierno central trató en lo posible de efectuar algunas dotaciones pero la mayoría de las veces esa era una responsabilidad de las autoridades locales y de las comunidades. No hay duda de que el fomento de la educación pública en tiempos republicanos trajo consigo un impulso a la producción de libros y materiales didácticos después de una larga etapa de estancamiento vivida por cuenta de las guerras de Independencia.

Sin duda, los mayores índices de circulación de libros y textos de estudio contribuyeron a forjar una educación más amplia y cimentada que de alguna manera reforzaba las clases y orientaciones diarias impartidas por los preceptores, siendo además una importante herramienta para los alumnos.

A principios de octubre de 1822, cuando el general Antonio José de Sucre, intendente del departamento de Quito, se enteró de la misión que el gobierno le encomendó al padre Mora Bermeo para implantar escuelas lancasterianas en los territorios del Sur, de inmediato adelantó gestiones con miras a traer pizarras y otros útiles desde Guayaquil. ${ }^{67}$

Hacia 1824, el gobierno ordenó que en todas las escuelas se enseñara el catecismo escrito por el licenciado José Grau, el cual incluía las bases de derecho político. ${ }^{68}$ En diciembre de este año, el intendente del departamento de Azuay solicitó al gobierno central asentado en Bogotá el envío de varios silabarios con el fin de destinarlos al proceso de implementación de escuelas lancasterianas que debía emprender el padre Mora Bermeo. En respuesta a esta petición, se recibieron en abril de 1825 un total de 9 colecciones de silabarios y 10 más en octubre para ser repartidas en las escuelas del Departamento. ${ }^{69}$

Desde Bogotá se realizó otro envío a principios de este mismo año, esta vez dirigido a la escuela lancasteriana de Quito. En el cargamento venían 77 ejemplares de los "Elementos de Aritmética", 130 silabarios, 500 lápices y un lapicero. Al recibir estos elementos, el intendente José Félix Valdivieso aprovechó la ocasión para proponer la creación de un fondo para premiar a los estudiantes más sobresalientes con recursos provenientes de la renta de propios de la ciudad de Quito. El secretario del Interior estuvo de acuerdo con otorgar estos incentivos pues los consideraba clave para promover el

67. Ibíd., f. 713r.

68. J. Grau, Catecismo político arreglado a la Constitución de la República de Colombia de 30 de agosto de 1820 (Bogotá: Imprenta de la República por N. Lora, 1824), 1-58. Tomado de BNC, Fondo Pineda, t. 711, pieza 10.

69. AGN, Fondo Ministerio de Instrucción Pública, t. 106, ff. 622r, 699r. 
progreso académico y prometió asimismo enviar más materiales para dotar los planteles de la provincia de Imbabura. ${ }^{70}$

En abril de 1826, pocas semanas después de inaugurada la escuela lancasteriana de la ciudad de Loja, el gobernador provincial Manuel Carrión solicitó al ejecutivo central el envío de ocho ejemplares de las tablas para la enseñanza mutua con el fin de dotar a otras escuelas que estaban próximas a abrirse en esta provincia. ${ }^{71}$ En el mes de septiembre el secretario del Interior adelantó trámites con miras a importar de Jamaica o Inglaterra un buen número de pizarras para atender la demanda de estos elementos en los departamentos del Sur. ${ }^{72}$

\section{CONSIDERACIONES FINALES}

La educación pública se constituyó en un factor clave en el Ecuador durante sus primeros años de vida republicana. Para el gobierno esta era una gran prioridad pues "requería, para su propio sostén y desarrollo, de una ancha base de opinión ciudadana, que solo podía construirse a partir de un ampliado y moderno sistema público de educación". ${ }^{73}$

Sin embargo, aún podía palparse el juego de fuerzas entre la mentalidad del antiguo régimen español cimentado en la moral católica y, por otro lado, un nuevo esquema de pensamiento liberal que apuntaba cada vez más hacia la racionalidad, la modernidad y la secularización. Dentro de este proyecto liberal la educación popular se concibió como un instrumento civilizatorio y como un medio de adaptación a los valores republicanos. ${ }^{74}$

Desde muy temprano, el Estado republicano dejó ver su intención de establecer una participación y una vigilancia más activa en el nivel de educación básica que desde tiempo atrás había recibido gran influencia de la Iglesia. A pesar de esto, el clero secular y regular mantuvieron su rol de liderazgo en el proceso formativo y eso se vio reflejado claramente en la gestión desarrollada por el padre Mora Bermeo en la difusión del método lancasteriano.

Los ambiciosos planes en cobertura de educación primaria se vieron seriamente afectados por la crisis económica, el déficit fiscal y la tensión

70. Ibíd., ff. 663r, 697r.

71. Ibíd., Fondo Funcionarios Públicos, t. 6, f. 236v.

72. Ibíd., Fondo Ministerio de Instrucción Pública, t. 106, f. 617r.

73. Núñez Sánchez, "Inicios de la educación pública...", 9.

74. Carlos Newland, "La educación elemental en Hispanoamérica: desde la Independencia hasta la centralización de los sistemas educativos nacionales", Hispanic American Historical Review 1, n. ${ }^{\circ}$ (1991): 339. 
político-militar en medio de una frágil y fluctuante estructura administrativa. Ante este contexto, valiosas fueron las fuentes de financiación privada y mancomunada que le imprimieron un nuevo aliento al proyecto educativo en marcha.

Aunque nadie desconoce que aumentó sustancialmente el número de alumnos en estos años, aún quedaba mucho por saldar la brecha educativa, es decir, brindar más oportunidades a las minorías étnicas y a los sectores más vulnerables de la sociedad, sectores que seguían a la expectativa de gozar de las mismas prerrogativas que el resto de ciudadanos en el marco de un nuevo régimen que pregonaba la igualdad y la libertad como dos de sus principios básicos.

Finalmente, hacia el año de 1830 varios factores económicos y políticos, entre ellos particularmente el excesivo centralismo, precipitaron la disolución de la Gran Colombia, momento a partir del cual el Ecuador da inicio a una nueva fase como nación libre e independiente ${ }^{75}$ en donde la educación seguiría siendo un tema crucial de su devenir histórico.

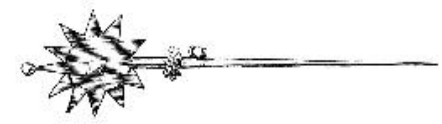

\title{
FUENTES Y BIBLIOGRAFÍA
}

\author{
FUENTES PRIMARIAS INÉDITAS
}

\section{Archivos}

Archivo General de la Nación (AGN), Bogotá-Colombia. Sección República.

Fondo Funcionarios Públicos.

Fondo Ministerio de Instrucción Pública.

Biblioteca Nacional de Colombia (BNC), Bogotá.

Fondo Pineda.

Fondo Quijano.

\section{Periódicos}

El Constitucional. Bogotá: Impreso por Arturo Carlos Luthman, 1827.

Gaceta de Colombia. Bogotá: Imprenta de Nicomedes Lora, 1822-1827.

75. Su primera Constitución Política, promulgada el 22 de septiembre de 1830, le confirió al Congreso de la República la responsabilidad de promover la educación pública. 


\section{FUENTES PRIMARIAS IMPRESAS}

Actas del Congreso de Cúcuta 1821. Vol. II. Bogotá: Biblioteca de la Presidencia de la República, 1990.

Blanco-Fombona, Rufino, compilador. Simón Bolívar. Discursos y proclamas. París: Garnier Hermanos, 1913.

Codificación nacional de todas las leyes de Colombia desde el año de 1821. T. VII. Bogotá: Imprenta Nacional, 1924.

Constitución de la República de Colombia. Rosario de Cúcuta: Bruno Espinosa, Impresor del Gobierno General, 1821.

Cortázar, Roberto, compilador. Cartas y mensajes del General Francisco de Paula Santander. Vol. 3. Bogotá: Academia Colombiana de Historia, 1956.

Fernández de Sotomayor y Picón, Juan. Catecismo o instrucción popular. Bogotá: En la Imprenta del C. B. E., 1820. Tomado de Biblioteca Nacional de Colombia. Fondo Quijano. T. 426, pieza 1.

Grau, J. Catecismo político arreglado a la Constitución de la República de Colombia de 30 de agosto de 1820. Bogotá: Imprenta de la República por N. Lora, 1824. Tomado de Biblioteca Nacional de Colombia. Fondo Pineda. T. 711, pieza 10.

Hernández de Alba, Gregorio, compilador. "Sumarias de los procesos seguidos contra los clérigos patriotas". Boletín de Historia y Antigüedades XLIX, n. ${ }^{\circ}$ 573-574 (1962): 345-436.

Ley Fundamental de la República de Colombia. Angostura, 1819. Tomado de Biblioteca Nacional de Colombia. Fondo Pineda. T. 852, pieza 14.

López Domínguez, Luis Horacio, compilador. De Boyacá a Cúcuta. Memoria administrativa, 1819-1821. Bogotá: Biblioteca de la Presidencia de la República, 1990.

López Domínguez, Luis Horacio, compilador. Obra educativa de Santander 1819-1826. Vol. I. Bogotá: Biblioteca de la Presidencia de la República, 1990.

Manual del sistema de enseñanza mutua aplicado a las escuelas primarias en los niños. Bogotá: Impreso por S. S. Fox, 1826.

Osorio, Alejandro, y Estanislao Vergara. Los encargados de la Secretaría General del Departamento de Cundinamarca presentan a S. E. el General F. de P. Santander, vicepresidente del mismo Departamento, la memoria correspondiente al año de 1820. Bogotá: Imprenta de Espinosa, 1821.

Osorio Racines, Felipe. Decretos del General Santander 1819-1821. Bogotá: Universidad Nacional, 1969.

\section{FUENTES SECUNDARIAS}

Ahern, Evelyn. “El desarrollo de la educación en Colombia: 1820-1850". Revista Colombiana de Educación, n. ${ }^{\circ}$ 22-23 (1991): 5-88.

Bushnell, David. El Régimen de Santander en la Gran Colombia. Bogotá: El Áncora, 1985.

Bustos Lozano, Guillermo. "La redefinición del orden colonial". En Manual de Historia del Ecuador. Épocas Aborigen y Colonial, Independencia. Quito: Universidad Andina Simón Bolívar, Sede Ecuador / Corporación Editora Nacional, 2008. 
Clark, Meri L. “Conflictos entre el Estado y las élites locales sobre la educación colombiana durante las décadas de 1820 y 1830". Historia Crítica, n. 34 (2007): 32-61.

Delgado Ayora, Julio César. "Iglesia y educación pública en Quito y en Cuenca a fines del período colonial (1750-1809)". Tesis de licenciatura. Universidad de Cuenca. 2011.

Mantilla, Luis Carlos. Los Franciscanos en Colombia. T. III. Vol. 2. Bogotá: Ediciones de la Universidad de San Buenaventura, 2000.

Martínez Boom, Alberto. Escuela, maestro y métodos en Colombia 1750-1820. Bogotá: Universidad Pedagógica Nacional, 1986.

Neissa de Mantilla, Ana Carmen. La evolución del pensamiento educativo de Simón Bolívar. Principios vigentes en los modelos pedagógicos del tercer milenio. Bogotá: Gente Nueva, 2005.

Newland, Carlos. "La educación elemental en Hispanoamérica: desde la Independencia hasta la centralización de los sistemas educativos nacionales". Hispanic American Historical Review 1, n. ${ }^{\circ} 2$ (1991): 335-362.

Núñez Sánchez, Jorge. “Inicios de la educación pública en el Ecuador". Procesos: revista ecuatoriana de historia, n. ${ }^{\circ} 13$ (1999): 3-23.

Paladines Escudero, Carlos, compilador. El movimiento Ilustrado y la Independencia de Quito. Quito: Fonsal, 2009.

Pita Pico, Roger. "La función política de las celebraciones públicas durante el proceso de Independencia de Colombia: en la búsqueda de la legitimidad y la lealtad". Revista Historia y Sociedad, n. $^{\circ} 23$ (2012): 175-205.

Safford, Frank. El ideal de lo práctico. El desafío de formar una élite técnica y empresarial en Colombia. Bogotá: Universidad Nacional / El Áncora, 1989.

Sanabria Munévar, Francisco. "Enseñando mutuamente: Una aproximación al método lancasteriano y a su aprobación en Colombia". Revista Historia de la Educación Colombiana 13, n. ${ }^{\circ} 13$ (2010): 47-76.

Soasti Toscano, Guadalupe. "Pedagogía política ilustrada: de vasallo a ciudadano, lo que produjo el conocimiento de los Derechos del Hombre y del Ciudadano", 293-318. En Política, participación y ciudadanía en el proceso de Independencia de la América Andina, compilado por Guadalupe Soasti. Quito: Fundación Konrad Adenauer, 2008.

Terán Najas, Rosemarie. “La escolarización de la vida: El esfuerzo de construcción de la modernidad educativa en el Ecuador (1821-1921)". Tesis doctoral. Universidad Nacional de Educación a Distancia, UNED. Madrid, 2015.

Tovar Pinzón, Hermes. Convocatoria al poder del número. Santa Fe de Bogotá: Archivo General de la Nación, 1994.

Villalba, Jorge, S. J. "Bolívar y la educación en el Ecuador". Revista de la Universidad Católica del Ecuador, n. ${ }^{\circ}$ 42, año XIII (1985): 147-191. 



\title{
La Acción Católica en Cuenca: De las asociaciones obreras a la "ciudadanía moral" en el primer tercio del siglo $\mathrm{XX}^{*}$
}

\author{
Catholic Action in Cuenca. From workers associations \\ to "moral citizenry" in the first third of the twentieth century
}

Juan Martínez Borrero

Universidad de Cuenca (Ecuador) juan.martinezb@ucuenca.edu.ec

DOI: http:/ / dx.doi.org/10.29078/ rp.v0i46.649

Fecha de presentación: 2 de mayo de 2017 Fecha de aceptación: 11 de septiembre de 2017

Artículo de investigación

* Este artículo es resultado de la investigación DIUC Universidad de Cuenca "Hacia los fundamentos de la ciudadanía en Azuay: organización y participación colectiva en el período 1900-1960". 
RESUMEN

El desarrollo de la ciudadanía en Azuay, Ecuador, durante el primer tercio del siglo XX, estuvo relacionado con la Acción Católica, movimiento seglar tutelado por la Iglesia que pretendía recuperar

los espacios que la sociedad tradicional y conservadora creía que podían perderse ante los cambios sociales y políticos de la emergente modernidad. Durante este período, Cuenca se vio afectada por transformaciones económicas, sociales, urbanísticas y culturales, siendo notable la apertura comercial hacia Europa y la consecuente circulación de ideas. La Acción Católica encaminó la organización obrera en función de su propio ideario, en contraposición a los conceptos liberales y a la presencia creciente de la ideología socialista. Los seglares impulsaron una "ciudadanía moral" cristiana que definió las bases de una sociedad predominantemente conservadora.

Palabras clave: historia social, ciudadanía moral, Iglesia, Acción Católica, asociaciones obreras, gremios, Cuenca, Ecuador, siglo XX.

ABSTRACT

The development of a sense of citizenry in the province of Azuay, in Ecuador, during the first third of the twentieth century, was linked to the Catholic Action, a lay movement sponsored by the Church aimed at regaining the ground that traditional conservative society believed could be lost to the social and political changes of emerging modernity. During this period, Cuenca was being impacted by economic, social, urban, and cultural transformations, among which the most noteworthy were the opening up of trade with Europe and

the resulting flow of ideas. The Catholic Action steered organized

labor toward its own ideology, countering liberal concepts and the growing presence of socialist ideology. These lay persons promoted a "moral Christian citizenry" that laid the foundations for a predominantly conservative society.

Keywords: Social history, moral citizenry, the Church, Catholic Action, workers associations, trade unions, Cuenca, Ecuador, twentieth century

Juan Martínez Borrero

Doctor en Ciencias de la Educación en Historia y Geografía por la Universidad de Cuenca, magíster en Historia de América por la Universidad Pablo de Olavide de Sevilla. Profesor principal de la Universidad de Cuenca. Ha orientado su investigación hacia la nueva historia cultural y, en particular, a la historia de las prácticas culturales populares desde el arte, la vida cotidiana, la alimentación y los oficios tradicionales. 


\section{INTRODUCCIÓN}

El primer tercio del siglo XX es una etapa fundamental en la consolidación política y económica del Ecuador, tal como han planteado los historiadores Juan Maiguashca y Liisa North. ${ }^{1}$ En lo social también hubo grandes cambios, razón por la cual y ante el creciente poder del liberalismo y la presencia de la modernización, la Iglesia impulsó el desarrollo de la Acción Católica, cuyo origen se remonta a 1863 y fue entendida como "la participación de los seglares en el apostolado jerárquico de la Iglesia", ${ }^{2}$ según definición de Pío XI y orientada hacia la "re cristianización de la sociedad". ${ }^{3}$ Debe comprenderse que el Ecuador había sido consagrado en 1873 por el presidente García Moreno al "Corazón de Jesús", en un intento de crear un vínculo profundo entre el sistema político de la joven nación y la condición fundamental del ciudadano cristiano, tal como lo ha estudiado Hidalgo Nistri. ${ }^{4}$ Por su parte Buriano Castro señala que, aunque este fue un proyecto nacional que, entre otros aspectos, transformó a la Iglesia en un brazo político del Estado, algunas regiones, y entre ellas en particular la provincia del Azuay, desarrollaron proyectos locales que se distinguieron políticamente de la perspectiva garciana. ${ }^{5}$

La reciente investigación de Chalco desarrolla una cercana visión de la práctica de la caridad emprendida por las élites que constituían en Quito el eje de la Acción Católica, y su accionar en el contexto sociopolítico y de la organización obrera, de la cual será la CEDOC, fundada en 1938, su forma más visible, aunque los antecedentes se remontan a la creación en Quito del Centro Católico de Obreros en $1906 .{ }^{6}$ Las tensiones al interior de los movimien-

1. Juan Maiguashca y Liisa North, "La cuestión regional en la historia ecuatoriana: 1830-1972". En Nueva Historia del Ecuador, edit. por Enrique Ayala Mora, vol. 12 (Quito: Grijalbo / Corporación Editora Ecuatoriana, 1991).

2. Pietro Parente, Antonio Piolanti y Salvatore Garofalo, Diccionario de Teología Dogmática (Barcelona: Editorial Litúrgica Española, 1955), 3.

3. Jessica E. Blanco, Modernidad conservadora y cultura política: La Acción Católica en Argentina (1931-1941) (Córdoba: Facultad de Filosofía y Humanidades de la Universidad Nacional de Córdoba, 2008).

4. Fernando Hidalgo Nistri, La República del Sagrado Corazón (Quito: Universidad Andina Simón Bolívar, Sede Ecuador / Corporación Editora Nacional, 2013).

5. Ana Buriano Castro, Navegando en la borrasca. Construir la nación de la fe en el mundo de la impiedad, Ecuador 1860-1875 (Ciudad de México: Instituto Mora, 2008).

6. Maritza Soledad Chalco, "Caridad y Acción Católica en Quito. Discurso y prácticas de la élite en torno a los pobres y obreros en los años treinta" (tesis de maestría, FLACSO Ecuador, 2017), http: / / repositorio.flacsoandes.edu.ec/xmlui/handle/10469/ 12439 ?show $=$ full. 
tos católicos y la participación de las élites y los grupos subalternos han sido estudiadas por Enríquez, quien trata en forma extensa "la cuestión social". 7 Desde la perspectiva de la construcción de la ciudadanía, la Acción Católica se constituyó en una forma de organización seglar, bajo la vigilancia de la Iglesia, cuya estructura, fines y objetivos estaban claramente determinados en la normativa que circulaba profusamente en el período señalado y cuya intervención en la práctica ciudadana fue notable logrando resultados de carácter permanente, algunos de los cuales pueden ser observados en Cuenca hasta hoy. El contexto social y político de la Acción Católica ha sido estudiado en detalle por Aspe Armella para México, resaltando el sentido cultural de la religión, la vinculación entre la jerarquía eclesiástica y los niveles intermedios, a más de los laicos y la particularidad "totalizante" de la religión. ${ }^{8}$

Por otra parte, Jessica Blanco asumió el estudio de la relación entre cultura política y modernidad conservadora desde la perspectiva de la esfera pública de Habermas en Córdoba, Argentina de 1931 a 1941, señalando cómo se construyó una "modernidad" desde la Acción Católica en el plano económico y con la consecuente transformación social, pero definiendo la modernización del pensamiento, de la moral y la expresión como inapropiadas. ${ }^{9}$ En el caso de Cuba el estudio de Fernández Soneira estableció las bases de la acción laica al interior de la Iglesia, destacando su importancia para la consolidación de la acción misionera. ${ }^{10}$

El estudio de la Acción Católica en América Latina es entonces relevante, y ha sido investigado profundamente. Nuestro trabajo se centrará en la consolidación de la acción ciudadana y el impulso a la moralidad que pretendió defender la familia cristiana de los vicios de la modernidad, reconociendo la importancia de las otras visiones que complementan la que planteamos.

La Acción Católica opuso un concepto moralizador tradicional a los procesos de modernización, que se habían desarrollado en Cuenca desde finales del siglo XIX, y ejerció una gran influencia sobre las asociaciones de obreros que se irán constituyendo bajo la estricta vigilancia de la Iglesia. Las consecuencias de estas acciones serán permanentes y construyen una "ciudadanía

7. Óscar Enríquez Capa, “Hegemonía y voz autorizada: la cuestión social como espacio de disputa entre subalternos y mandos católicos y conservadores en Quito durante la década de 1930" (tesis de maestría, FLACSO Ecuador, 2015), http: / / repositorio.flacsoandes.edu.ec/ bitstream/10469/9728/2/TFLACSO-2015OEEC.pdf.

8. María Aspe Armella, La formación social y política de los católicos mexicanos. La Acción Católica Mexicana y la Unión Nacional de Estudiantes Católicos, 1929-1958 (Ciudad de México: Instituto Mexicano de Doctrina Social Cristiana / Universidad Iberoamericana, 2008).

9. Jürgen Habermas, Historia y crítica de la opinión pública. Transformación estructural de la vida pública (Barcelona: Gustavo Gili, 1994).

10. Teresa Fernández Soneira, Con la estrella y la cruz: Historia de la Federación de las Juventudes de Acción Católica Cubana (Miami: Universal, 2002). 
moral" vigilante, y de carácter permanente, a través de la acción de los seglares en diversos ámbitos de la vida privada.

\section{La CONSOLIDACión de la AcCión CATÓlica EN El ECUAdor}

Los Estatutos Generales de la Acción Católica Ecuatoriana se publicaron en 1930. ${ }^{11}$ Mientras que en 1932 aparecerá el Pequeño Catecismo de la Acción Católica de monseñor Fontenelle, con prefacio de monseñor Pizzardo, en ese entonces secretario general de la Acción Católica en Roma, traducido del francés por "una socia" de la Sección Femenina e impreso en Cuenca, en la tipografía Diasur. ${ }^{12}$ En 1933 se imprimieron, en la Imprenta del Clero, las Normas para la organización y funcionamiento de los centros y núcleos parroquiales de la Acción Católica del Azuay, bajo la responsabilidad del Comité Ejecutivo de la Sección Masculina y fue firmado por el asistente, presbítero Manuel de Jesús Serrano Abad, y por el presidente del Comité Ejecutivo, Dr. Octavio Chacón Moscoso. ${ }^{13}$ A estas publicaciones se sumaron el ensayo del padre Jorge Fernández Pradel S. J. Los sindicatos católicos de obreros publicado por el Secretariado de la Acción Católica de Ibarra en 1939, ${ }^{14}$ en segunda edición "notablemente aumentada" por el presbítero Arsenio Torres y el extenso trabajo de Silvio Luis Haro Alvear, doctor en derecho canónico, intitulado Primeras nociones de Acción Católica. Estudio Documentado, publicado en Quito por la Editorial Ecuatoriana en $1938,{ }^{15}$ que desarrollaba ampliamente las bases conceptuales y organizativas de este movimiento. Este breve recuento de un campo mucho más extenso, y cuya manifestación es permanente en los periódicos católicos locales, nos da una idea del gran impulso que recibió esta actividad seglar y las acciones que desarrolló. 1939).

11. Estatutos Generales de la Acción Católica Ecuatoriana (Cuenca: Imprenta del Clero,

12. Monseñor Fontenelle, Pequeño Catecismo de la Acción Católica [traducción de una socia no identificada de la FCA] (Cuenca: Tipografía Diasur, 1932).

13. Manuel de Jesús Serrano y Octavio Chacón Moscoso, Normas para la organización y funcionamiento de los centros y núcleos parroquiales de la Acción Católica del Azuay (Cuenca: Imprenta del Clero, 1933).

14. Jorge Fernández Pradel S. J., Los sindicatos católicos de obreros, segunda edición notablemente aumentada por el presbitero Arsenio Torres (Ibarra: Secretariado Económico Social de la Acción Católica de Ibarra, 1939).

15. Silvio Luis Haro Alvear, Primeras nociones de Acción Católica. Estudio Documentado (Quito: Editorial Ecuatoriana, 1938). 
Entre 1930 y 1940 "la Iglesia se propuso más decididamente construir una verdadera contra-sociedad a través de un paralelismo católico, creador de sindicatos, universidades, colegios, escuela, prensa y movimientos católicos de todo tipo", ${ }^{16}$ aspectos notables también en el Ecuador.

\section{Cuenca EN El PRIMER Tercio Del Siglo XX: ModernidAd Y CONSERVADURISMO}

Para comprender los procesos de modernización en Cuenca durante el primer cuarto del siglo $X X$, y que fueron ásperamente combatidos por la Acción Católica, debemos señalar que la región había vivido cambios limitados, aunque intensos, cuyas consecuencias son de índole muy diversa. En lo económico la base productiva agrícola, que caracterizaba a una región con escasos latifundios y una notable distribución de la tierra en el ámbito rural, había dado paso desde la segunda mitad del siglo XIX a la explotación de los bosques de cascarilla o quina en zonas cercanas a Cuenca y a Loja. ${ }^{17} \mathrm{El}$ producto resultante se exportaba a Europa, en particular a la Gran Bretaña, en donde se procesaba para obtener el sulfato de quinina, indispensable para la dominación colonial de la India, por sus cualidades antifebrífugas; existió también, aunque más bien limitada, la explotación de otros productos silvícolas, como la zarzaparrilla o el bejuquillo.

A estos productos, se agregó el cada vez más importante tejido de sombreros de paja toquilla, en particular los de estilo "Cuenca", que eran exportados por numerosas casas comerciales instaladas en la ciudad y que tenían como destino el mercado mundial. Sumándose esta producción a la de Manabí en números notables para su exportación, un rubro que benefició al país y a dichas zonas por años. Se trata entonces de una sociedad en la que la explotación silvícola y el trabajo artesanal a destajo, constituyen la base de la economía, sin minusvalorar la pequeña agricultura y explotación pecuaria también importantes.

Las consecuencias inmediatas de estos sistemas a escala mayor fueron, entre otras muchas, principalmente dos. La primera fue la disponibilidad inédita de capitales por parte de los empresarios regionales, y la segunda la ampliación de la base de trabajadores a destajo en el campo y la ciudad,

16. Rodolfo de Roux López, "Los inciertos parajes de una nueva geografía religiosa en América Latina", L'Ordinaire latino-américain, IPEALT, Université de Toulouse-Le Mirail, n. ${ }^{\circ}$ 200-201 (abril-septiembre 2005): 16.

17. Véase Leonardo Espinoza y Lucas Achig, Breve historia económica de la región cañari (Cuenca: CREA, 1981); Silvia Palomeque, Cuenca en el siglo XIX, la articulación de una región (Quito: FLACSO Ecuador / Abya-Yala, 1990). 
notablemente desprotegidos de derechos laborales y sociales, y cuyas condiciones de explotación determinaron el surgimiento de una población depauperada que sustentaba el crecimiento económico de la región sin recibir apenas beneficio monetario.

Una notable porción de los ingresos que fluyen a Cuenca por esta nueva estructura económica son los que sustentan su transformación arquitectónica, a una escala nunca antes vista, decenas de casas son derruidas para construir nuevas edificaciones y otras tantas son modificadas en sus fachadas con los estilos en boga. Se derruyeron iglesias y edificios públicos y se reedificaron con nuevas propuestas. Así surgieron las iglesias de Todos Santos, Santo Domingo, San Blas, San Alfonso, Santo Domingo, El Cenáculo, San Sebastián, La Merced, el Corazón de Jesús y la notable Catedral de la Inmaculada, que se edificó casi sobre la antigua iglesia jesuita. Es evidente que el poder de la Iglesia corre a la par del poder civil y político, puesto que notables fueron las sumas invertidas en la reedificación de sus templos.

Parte de los capitales que se acumularon por la exportación de los productos señalados se invertirán en procesos de modernización tecnológica; así Roberto Crespo Toral construye en 1914 la planta eléctrica que prontamente prestará este importante y moderno servicio a la ciudad, se implementará más tarde la central telefónica, pero también se construyen colectores subterráneos para aguas servidas y se inician los procesos de adoquinamiento de las calles y de dotación de servicio de agua potable en el centro de Cuenca.

Mientras tanto, había una circulación de bienes diversos que se importaban desde Europa, como vestimenta al estilo de París y muebles de Viena; al mismo tiempo venían también complementos para la arquitectura como latón para cielos rasos, balcones y verjas de hierro. Se sigue una corriente de consumo que es similar en otros lugares de América Latina y que poco a poco va consolidando una visión distinta de la realidad, en donde se abandonaba la dependencia tradicional de los bienes de producción artesanal a favor de bienes industriales europeos. ${ }^{18}$ Una de las consecuencias de estas nuevas pautas de consumo es la liberación de la mano de obra artesanal y su reorientación hacia labores dependientes y a destajo, como el tejido de sombreros y la explotación de recursos silvestres.

La circulación de bienes estuvo acompañada de una circulación de ideas y de cultura, los objetos, como se conoce bien, no llegan solos, sino que se acompañan de nuevos conceptos. El creciente comercio de ida y vuelta llevó a algunos cuencanos, y cuencanas, a Europa, especialmente a París y Londres, y desde allí llegaron otras miradas sobre el mundo, otros estilos litera-

18. Arnold Bauer, Somos lo que compramos. Historia de la cultura material en América Latina (Madrid: Taurus, 2002). 
rios, conceptos más abiertos sobre la realidad e inclusive nuevas ideas sociales y políticas. El viaje de Honorato Vázquez a Europa, con sus hijos María y Emmanuel Honorato, dejará huellas en los tres; aquellos personajes luego ejercerán notable influencia en la cultura local. Así mismo Federico Malo introducirá el spleen británico y una nueva visión del comercio, en una sociedad ansiosa de estímulos, tal como puede entenderse del acelerado cambio urbano y de estilos.

A estos elementos se sumaron la formación de los "teatros", que paulatinamente incorporaron el cinematógrafo convirtiéndose en las primeras salas de proyecciones, toda una novedad así como un gran escándalo sobre el cual la Acción Católica pondrá su mano moralizadora; ${ }^{19}$ la presencia de la radio y las emisoras; la profesionalización de los diarios como portadores de noticias a más de opiniones como había sido lo habitual, y la aparición de las revistas literarias y culturales como Azul, Austral, América Latina y Philelia ${ }^{20}$ que junto a la Revista de la Corporación Universitaria del Azuay (hoy Universidad de Cuenca) y a la Revista del Centro de Estudios Históricos y Geográficos de Cuenca, desarrollaron una aproximación más abierta, experimental y curiosa de la realidad.

El surgimiento de voces disidentes, como las que aparecieron en Austral y Philelia, permitió el acceso a nuevas formas de expresión visual y poética, pero se trataba de sujetos que, además, llevaban a la vida real sus nuevas prácticas surgiendo la imagen del bohemio cuencano, escritor vanguardista, consumidor de pirófanos y morfina, admirador de la belleza, investigador y teórico curioso, y por todo esto fue visto como enemigo de la moral y las buenas costumbres y como elemento deletéreo del equilibrio social, ${ }^{21}$ tal como se señala en 1921 en un breve texto condenatorio en el periódico El Obrero Azuayo:

Personas muy sensatas [...] nos han manifestado la pésima impresión que ha causado en la sociedad ciertos grabados que se nos dice trae la última edición de Austral [...] y deplorar este lamentable extravío de quienes se creen autorizados para insultar a la moralidad y las buenas costumbres de una sociedad cristiana, recatada y culta, cual la de Cuenca ¿Y qué decir de quienes se prestan para hacerse fotografiar cuerpos limpios?22

19. Programa de Acción Católica de la Diócesis de Cuenca (Cuenca: Imprenta del Clero, 1941): 2-3.

20. Michael H. Handelsman, El modernismo en las revistas literarias del Ecuador: Ensayo preliminar y bibliografía (Cuenca: Casa de la Cultura Ecuatoriana, Núcleo del Azuay, 1981).

21. María de los Ángeles Martínez Donoso, “Bohemia y vanguardia, el modernismo en Cuenca". En Alma Mía. Simbolismo y Modernidad. Ecuador 1900-1930, coord. por Alexandra Kennedy y Rodrigo Gutiérrez Viñuales (Quito: Fonsal, 2014), 136-137.

22. "Condenatorio", El Obrero Azuayo (27 de noviembre de 1921): s. r. 
Dichas imágenes, de autoría de Cornelio Crespo Vega y de Emanuel Honorato Vázquez, son una manifestación visible del proceso de modernización del pensamiento de este grupo de artistas y escritores.

A la par de estas nuevas visiones modernas es notable el crecimiento de una concepción tradicional del mundo y de la sociedad, de carácter muy conservador, y que, necesariamente, entrará en conflicto con las propuestas antes señaladas. La descalificación de personas y tendencias es muy común en diarios como El Obrero Libre, El Progreso o El Obrero Azuayo y, por supuesto desde los púlpitos. Uno de los más importantes brazos ejecutores de esta visión será la Acción Católica, que se empeñó en mantener a la sociedad controlada y dependiente, a través de la tarea de los seglares que se ocuparon de los espacios a los que no llegaba el sacerdote, es decir la familia, la calle, el taller. Con el apoyo de las asociaciones de obreros católicos, entre las que se cuenta la "Alianza Obrera", fundada en 1904, y cuya actividad y participación social es notable durante el primer tercio de ese siglo.

La Iglesia, mediante sus prácticas pastorales, la organización de los trabajadores y la Acción Católica, pudo penetrar profundamente en la sociedad difundiendo su visión del mundo y de la moral, y constituyéndose en la estructura vertebral de la comunidad, con lo que su capacidad para oponerse a la "modernidad" y las ideas liberales y socialistas es muy grande. ${ }^{23}$

La intervención conservadora desde el púlpito es frecuente. En carta manuscrita sin fechar y sin autor, que se podría atribuir al obispo de Cuenca, Daniel Hermida en la década de 1920, se protestaba por la publicación en los diarios El Progreso y La Voz Pública de información sobre conferencias universitarias donde se trató el tema de la religión, y además se amonestaba a los fieles para que

no puedan concurrir a conferencias en que se trate de religión o de materias conexas con ella, cuando no han sido aprobadas por la Autoridad Diocesana, como lo mandan los cánones del nuevo código eclesiástico; y que ni se pueden leer libros, folletos, hojas sueltas o periódicos que publiquen errores contra el Dogma, las buenas costumbres y la Filosofía católicos. ${ }^{24}$

La tensión es evidente sobre todo cuando el documento concluye "que de esta docilidad se seguirá la paz tan anhelada para nuestra Diócesis". ${ }^{25}$

23. Holger Dután, "Cuando los curas formaban sindicatos". En Estudios, crónicas y relatos de nuestra tierra, ed. por María Rosa Crespo, t. II (Cuenca: Casa de la Cultura Ecuatoriana, Núcleo del Azuay, 1992), 121-127.

24. Atribuida al Obispo Daniel Hermida, "Carta Pastoral" Cuenca, ca. 1920, Archivo de Curia Arquidiocesana de Cuenca (ACA/C).

25. Ibíd. 


\section{La Acción Católica y su influjo SOBRE LA ORGANIZACIÓN OBRERA}

En 1926 se afirmaba, en la recopilación de discursos por el aniversario de la "Alianza Obrera del Azuay", que la Acción Católica "es el más poderoso movimiento del mundo católico [...] y apoya y trabaja para la reconstrucción, si es lícito decirlo, de las sociedades y naciones". ${ }^{26}$ En el Azuay, en 1933, la organización de la Acción Católica es una realidad y en Cuenca "donde se ha iniciado, cuenta con agrupaciones de caballeros, de señoras, de jóvenes, de señoritas, de obreros y de varios núcleos parroquiales que han organizado las feligresías urbanas". ${ }^{27}$ Estas acciones se enmarcan en la beneficencia, como una forma moderna de la caridad Cristiana, un concepto que no es ajeno a la discusión entre la perspectiva liberal y la propia de la Iglesia y los seglares católicos tal como se manifestó en el primer tercio del siglo XX. ${ }^{28}$

El planteamiento conceptual señalaba que estas actividades deberán realizarse, fundamentalmente, porque "el mundo ha torcido sus rumbos con respecto a su fin supremo" ${ }^{29}$ y que por lo tanto la acción de los seglares es la única capaz de llevar la palabra del evangelio a donde no llegaba el sacerdote "por el ambiente de odio que todos los días se propaga contra la Religión Católica", teniéndose como fin "la conquista de almas mediante el apostolado seglar, en todos los campos en donde no puede ejercer su acción el sacerdote". ${ }^{30}$ Estos elementos forman parte de una política consensuada de la Iglesia y los seglares católicos para responder, por una parte, a la creciente presencia del socialismo y su influjo en las asociaciones obreras y, por otra, para proponer una vía cristiana como soporte del obrerismo, al que dichas alternativas no pueden responder apropiadamente. Como señaló en su momento Bustos "la clase se vio estructurada en diversos aspectos a imagen y semejanza de la realidad que la creaba, y en ese sentido reprodujo el orden social, al mismo tiempo que en ocasiones lo desafió". ${ }^{31}$

26. Discursos leídos en una sesión solemne de la Alianza Obrera del Azuay, 5 de diciembre de 1926 (Cuenca: Imprenta del Clero, 1926), 3.

27. Serrano y Chacón, Normas para la organización..., 1.

28. Eduardo Kingman Garcés, "De la beneficencia de antaño a la auténtica caridad", Procesos: revista ecuatoriana de historia, n. ${ }^{\circ} 8$ (II semestre 1995 - I semestre 1996): 99-117.

29. Serrano y Chacón, Normas para la organización..., 2.

30. Ibíd.

31. Guillermo Bustos, "La identidad 'clase obrera' a revisión: una lectura sobre las representaciones del Congreso de Ambato de 1938”, Procesos: revista ecuatoriana de historia, n. 2 (1992): 73-104. 
El discurso que se proclamaba desde las asociaciones obreras tiene su especificidad, pero está claramente relacionado con la visión moral de la Iglesia. En este caso el peligro de la modernidad tiene un nombre propio, el socialismo, y así se proclamaba desde la visión de los dirigentes de los gremios católicos como la "Alianza Obrera" que, al ocupar su nueva sede en 1926, convierte la sesión solemne en el escenario apropiado para contrastar las visiones del artesano Manuel J. Bravo, que dará el discurso de fondo en dicha ocasión, y del ideólogo liberal José Peralta en textos como El problema obrero. Tema que analizaremos más adelante.

El concepto cristiano del trabajo se opone, según una publicación de $E l$ Obrero Azuayo de 1924, al de los juristas y economistas liberales, ya que estos consideraban que es "una simple mercancía que los obreros venden o alquilan a los patrones, concepto que no es conforme con la dignidad humana, cuyo trabajo, libre y racional, no es susceptible de venderse, ni mucho menos de alquilarse". ${ }^{32}$ Mientras que según un texto de 1921, de autoría de Alberto Laguna en El Obrero Azuayo: "el obrero es un ser dotado de libertad e inmortalidad [a quién] no es posible convertirlo en una divisa de la miseria ni en el estigma distintivo de una clase desgraciada". ${ }^{33}$

Estas ideas se ven apoyadas por una profunda desconfianza en los propósitos de los dirigentes liberales a los que se acusa de ser "como la zorra de la fábula [...] que en pomposos discursos pregonan la miserias, la postergación, las injusticias que se cometen contra el pobre pueblo, para el que reivindican ellos con lisonjera adulación todos los honores" solamente mientras son "aspirantes o cesantes políticos" pues, dice el mismo texto, "su generosidad no tiene otro objeto que el encontrar el chivo para salir del apuro, del pozo del descrédito, de la sima del olvido". ${ }^{34}$ Este punto de vista se reflejaba claramente en el "Himno Obrero" escrito por Luis Cordero Dávila ${ }^{35}$ en que el coro repite "Levantemos el himno sonoro/somos hijos del noble taller/ vale más el trabajo que el oro/nuestra gloria es cumplir el deber". Hay que recordar que los trabajadores azuayos "pertenecen al mundo artesanal. Carpinteros, zapateros, sastres, hojalateros, panaderos y otros artesanos conforman la fuerza laboral" ${ }^{36}$

En el texto Los sindicatos católicos de obreros del padre Fernández Pradel, encontramos que se discutía la definición de sindicato católico, afirmando

32. "El concepto cristiano del trabajo", El Obrero Azuayo (7 de febrero de 1924): s. r.

33. "Alberto Laguna" [El Obrero], El Obrero Azuayo (23 de enero de 1921): s. r.

34. Ibíd.

35. Luis Cordero Dávila, "Himno Obrero", Revista El Tres de Noviembre, n. ${ }^{\circ} 119$ (julio 1952): 91-92. Publicado por esta revista en los años cincuenta, el himno al que nos referimos debió ser escrito en los años veinte.

36. Dután, "Cuando los curas...", 121. 
que no es ni una "congregación o cofradía piadosa" ni un "organismo político" ya que debe mantenerse "siempre fuera y por encima de todo partido político"; tampoco, se dice, "es un instrumento de lucha en manos de la clase obrera contra los ricos", sino que debe intentar el acercamiento de "las clases sociales del capital y el trabajo; pero también salvaguarda los derechos del obrero". Se concluye que el Sindicato Católico de Obreros es "una fuerza poderosa, es un factor decisivo para el resurgimiento de la clase obrera y para el bienestar y progreso de la sociedad" y como señaló León XIII en su Rerum Novarum debe considerarse que su fin "consiste en que cada uno de los asociados obtenga el mayor aumento posible de bienes del cuerpo, del alma y de la fortuna". ${ }^{37}$

En lo religioso se indica explícitamente que el obrero católico no tendrá otras obligaciones que las del buen cristiano, y que de ninguna manera se le forzará "a la confesión mensual u otras formas de piedad". ${ }^{38}$ Los fines del Sindicato Católico son cuatro: Económico, Profesional, Cultural y Religioso. En lo político señala el autor que:

El Sindicato tiende a mejorar, en cuanto es posible y a medida de los recursos disponibles, la condición desgraciada, calamitosa e inmerecida en que se encuentran muchos obreros, como afirma León XIII [...] urge trabajar infatigablemente a fin de que el obrero disfrute del mayor número de medios para remediar las necesidades de su vida. ${ }^{39}$

El 5 de diciembre de 1926 el obispo Daniel Hermida consagró la capilla de la "Alianza Obrera", a donde se trasladó en procesión la imagen de Nuestra Señora del Río. Con este motivo se desarrolló una sesión solemne con la asistencia de los socios, sacerdotes, caballeros, padrinos y madrinas, en la que se presentaron varios discursos. La conferencia de fondo, que estuvo a cargo de Manuel J. Bravo, se tituló Disertación acerca del socialismo, que consta entre los discursos a los que ya nos hemos referido.

Para ese entonces, a 22 años de su fundación, la "Alianza Obrera”, según discurso de su presidente, Miguel Ángel Torres, contaba ya con la "Sección de Beneficencia, que favorece con el socorro diario, médico y medicinas a los enfermos, y últimamente se ha logrado fundar la Caja de Ahorros, de cuyos fondo recibirán importante alivio los deudos del socio que falleciere" pero también se ofrecían clases de música, servicios religiosos en días festivos, conferencias y lecturas "apropiadas para el obrero" para lo que contaban con

37. Fernández Pradel, Los sindicatos católicos..., 25-27.

38. Ibíd., 31.

39. Ibíd., 28-29. 
una incipiente biblioteca. Todo esto bajo "el mandato divino: comerás el pan con el sudor de tu frente". ${ }^{40}$

Resulta fundamental para nuestro análisis que esta organización obrera actúe, como dice en la presentación del volumen probablemente su director el canónigo Isaac Ulloa, bajo el mandato y la filosofía de la Acción Católica. Vemos entonces que la conformación de esta "ciudadanía moral", que se vincula en forma directa con un "orden social", ${ }^{41}$ alcanzaba a las organizaciones de trabajadores, ampliando su influencia, unos años más tarde, a la sociedad civil o para el caso la sociedad seglar.

En su Disertación acerca del socialismo, Manuel J. Bravo señalaba que, como artesano, está en capacidad de denunciar "a los hombres sin conciencia, a los falsos protectores del obrero que vienen proclamando la perniciosa doctrina de Marx y de Lenine [sic] y la incendiaria de Baulenine y sus secuaces". El socialismo, dice el orador, se basa en dos ideas principales: "derribar y destruir el actual régimen económico y social vigente, para sobre sus ruinas organizar la sociedad". ${ }^{42}$

Si bien Bravo señalaba que los fundamentos del socialismo son cinco: político, social, moral, religioso e internacional, se concentraba en el concepto de "propiedad privada" a la que atribuía un origen divino basado en la Ley Natural. Si esta se nacionalizara, ya no habría cariño al suelo, se perdería la virtud del amor patrio, nadie se ocuparía en tareas peligrosas o reputadas indignas, no se obedecería a la autoridad, en suma "prevalecería [...] en medio de la muchedumbre el egoísmo, el interés y la codicia, disputándose a dentellada limpia el soñado botín", por ello el pueblo debe someterse a la "democracia cristiana" asentada sobre los pilares de la civilización: Dios, Patria, Familia y Propiedad. ${ }^{43}$

El ideólogo de la Revolución Liberal ecuatoriana, el cuencano José Peralta, ${ }^{44}$ había expresado sus puntos de vista en el discurso El problema obrero publicado, años después de su muerte, por la revista de la Universidad de Cuenca. ${ }^{45}$ Este autor no se sumaba a la perspectiva socialista, ya que defien-

40. Discursos leídos en una sesión solemne..., 3-4.

41. Jaime Valenzuela Márquez, “Del orden moral al orden político. Contextos y estrategias del discurso eclesiástico en Santiago de Chile". En Máscaras, tretas y rodeos del discurso colonial en los Andes, ed. por Bernard Lavallé (Lima: IFEA / PUCP, 2005).

42. Manuel J. Bravo, "Disertación acerca del socialismo". En Discursos leídos en una sesión solemne de la Alianza Obrera del Azuay, 5 de diciembre de 1926 (Cuenca: Imprenta del Clero, 1926), 9.

43. Ibíd., 10.

44. María Cristina Cárdenas Reyes, José Peralta y la trayectoria del liberalismo ecuatoriano (Quito: Banco Central de Ecuador, 2002).

45. José Peralta, "El problema obrero", Anales de la Universidad de Cuenca, t. XI, n. ${ }^{\circ} 2$ (abril-junio de 1955): 169-182. 
de su punto de vista liberal, pero en la manera en que señalaba las responsabilidades históricas de la Iglesia y del capital, se asemejaba mucho a los conceptos que Bravo denuncia. La pasión es signo del discurso de Peralta, levantando la insignia del trabajador y del liberalismo afirma que:

Engañado por los aspirantes, víctima escogida por el despotismo y el sacerdocio, yunque eterno de todos los golpes, degollado en los mataderos de la guerra civil [...] el pueblo, como en los tiempos remotos, ha sido [...] una agrupación de esclavos desposeídos de toda preeminencia y derecho. ${ }^{46}$

Como se puede observar la tensión entre las perspectivas del socialismo internacional, del liberalismo radical y de la democracia cristiana es enorme, y el campo en que se dirimen estas diferencias es el de la organización de los trabajadores, artesanos y obreros a los que la Iglesia prestaba en Cuenca enorme atención. Podemos considerar apropiado lo que afirma Roux López:

Ya desde finales del siglo XIX y principios del XX, en reacción al liberalismo laicizante y a la aparición del socialismo, del comunismo y del anarquismo, había surgido un "catolicismo social" y a la par "integral", pues no se contentaba con el rol subalterno y marginal que le reservaba el Estado liberal a la Iglesia, sino que reivindicaba el derecho y el deber de modelar "íntegramente" la sociedad y el Estado, restaurando un orden social cristiano del que la Iglesia católica sería alma y cabeza. ${ }^{47}$

\section{La Acción Católica Y LA "CIUDADANÍA MORAL"}

El reconocimiento de las dificultades en la labor religiosa obligaba a sustentar el catolicismo en la acción individual de cada sujeto, pero basándose en los principios dogmáticos establecidos en las normas de la Acción Católica. La intervención de los miembros de esta en la sociedad pretendía una defensa de la moral cristiana en una sociedad en transformación, no solo política o económica, sino que además estaba envuelta en un proceso en el que se consideraba que se había producido una descomposición ética por el avance de la modernidad.

La acción del ciudadano deberá darse en la vida diaria, interviniendo en el hogar, el taller y en los grupos de amigos, mediante las prácticas piadosas y el cumplimiento de los deberes sociales e individuales con responsabilidad, justicia y entrega, recordando en especial a los niños. Estas acciones

46. Ibíd., 181.

47. Roux López, “Los inciertos parajes...”, 62. 
debían conducir a que el "apóstol", como se denomina al miembro de la Acción Católica, procurara "sin perdonar fatigas ni escatimar sacrificios, transformar la vida privada y pública, en el escenario en donde actúa, hasta los últimos reductos". ${ }^{48}$

No debió haber sido desdeñable la importancia de las indulgencias parciales de 100 días concedidas a los miembros que llevasen todo el día el distintivo de la Acción Católica, y las indulgencias plenarias a quienes asistieran a "los santos Ejercicios y cursos de cultura, de propaganda y de reuniones diocesanas o regionales, a condición de que terminen con una ceremonia religiosa oportuna, con Misa y Comunión General" y para los directores y propagandistas que al menos dos veces al mes den conferencias en las parroquias. Debe indicarse que estas indulgencias son concedidas por la Santa Sede a los dirigentes y socios de la Acción Católica "oficial". ${ }^{49}$

El objetivo de cambio se entendía como "moralización" de muchas prácticas cotidianas, algunas de las cuales deben ser objeto de acción inmediata. En el Programa General en que deberá actuar conjuntamente la Acción Social Católica de Cuenca de $1941,{ }^{50}$ se establecen estos campos, entre ellos el cine, la moda, el alcoholismo, los libros malos, el latrocinio, los bailes inmodestos, los cantos obscenos, los cuadros inmorales, la inmoralidad en los balnearios y el divorcio.

Se ha conocido, por testimonios de personas que mantienen viva en su memoria la Cuenca de la primera mitad del siglo XX, la práctica común de anotar, a veces con personas asomadas a los balcones cerca de los teatros, los nombres de los asistentes al cine para que en la prédica de los domingos se proclamasen desde el púlpito.

¿Por qué el cine? No hay garantías sobre su moralidad, se decía; por ello era necesario abstenerse de asistir y se planteó una campaña de "orientación" de la sociedad mediante publicaciones en las que escritores locales tocasen "los resortes sensibles aún, la dignidad, la fidelidad conyugal, el porvenir de la juventud" . ${ }^{51}$ Para la época el cine se había vuelto muy popular en Cuenca, con numerosos estrenos de películas de Hollywood y además una notable presencia de filmes mexicanos y argentinos. Se llegó a publicar revistas dedicadas a informar sobre los estrenos y que incluyen una modesta crítica cinematográfica.

Para enfrentar lo que se considera la principal fuente de corrupción moral, se propone un "plan de combate" de cinco puntos en el que se resalta que el cine:

48. Serrano y Chacón, Normas para la organización..., 3.

49. Ibíd., 11.

50. Programa de Acción Católica..., 1-10.

51. Ibíd., 1-2. 
a) Desarrolla la apología de todos los vicios.

b) Produce la ruina de los hogares porque de él nace el adulterio.

c) Arruina económicamente al obrero que usa en esta actividad un tercio o la mitad de su salario.

d) Impulsa el raterismo.

e) Introduce ideas deletéreas, materialistas. ${ }^{52}$

Pero además se afirmaba que es el cine el que "ha formado la mayor parte de los ladrones que infestan las ciudades", otra razón para denunciarlo. Es curioso que la razón esgrimida no sea la pobreza o la falta de trabajo, sino más bien la afición al cine.

En este afán de controlar la moral de los ciudadanos se enfrenta también la lectura de "libros malos", particularmente de novelas, apreciadas por los jóvenes y las señoritas, que provocan en la vida "una orientación plenamente inmoral". Por lo tanto, se planteaba que solamente puedan importarse al país y venderse en las librerías "libros serios [que no] fomenten las peores pasiones", ya que los "libros malos [en contraste] enervan la atención y dedicación de la inteligencia" de sus lectores..$^{53}$

En una publicidad del "Establecimiento de Moisés Marchán", publicada el 27 de noviembre de 1921 en El Obrero Azuayo, ${ }^{54}$ se ofrecían a la venta las obras de Rubén Darío, como Opiniones, Todo al vuelo, La caravana pasa, libros de José Enrique Rodó, como El mirador de Próspero, junto a obras de Gerard de Nerval, Les Plus belles pajes, Poemes de Gustave Qahn, de Jean Moreas, Les Stances, de Arthur Rimbaud, Les Iluminations, algunos de los que se consideran como "libros malos" y que fueron, hasta donde podemos conocer, ávidamente buscados por los lectores. Se vendían libros de autores españoles como Antonio Machado y Sus páginas escogidas, Juan Ramón Jiménez y Platero y yo, acompañados del Cántico espiritual de San Juan de la Cruz. También están a la venta diccionarios inglés-español e italiano-español así como un compendio de gramática latina. Había entonces de dónde escoger, y fueron muchos los textos combatidos desde la perspectiva moralista que los entiende como opuestos a las enseñanzas de la religión..$^{55}$

Había fracasado el intento de los ciudadanos de Cuenca, en 1902, de impedir la promulgación del matrimonio civil, y la consiguiente institución del divorcio. Un manifiesto apareció en los diarios locales con centenares de firmas de apoyo, la propuesta de la Acción Católica incluía la obligatoriedad

52. Ibíd.

53. Ibíd., 3.

54. "Establecimiento de Moisés Marchán", El Obrero Azuayo (27 de noviembre de 1921): s. r.

55. “Libros en venta", El Obrero Azuayo (27 de noviembre de 1921): s. r. 
de que, a través de la prensa y el púlpito, se rechace el divorcio y que se excluya de "los círculos sociales" a quienes se hubiesen vuelto a casar.

La situación de Cuenca obligaba también a actuar en la prevención y remediación del alcoholismo, un tema sobre el que escriben varios autores en los diarios y revistas de la época, publicándose ensayos de autores extranjeros que desmenuzan los aspectos deletéreos de la ingesta de alcohol. El compromiso de los escritores locales, aunque no fuesen católicos, fue el de afrontar este grave problema que afectaba a importantes sectores de la población, siendo, como se afirmaba, más frecuente entre los obreros. ${ }^{56}$

El alcoholismo es un pecado capital, se dice, y así debe predicarse desde el púlpito, es causa de escándalo, conduce a la ruina económica, la degeneración intelectual y moral y a la degeneración de la descendencia, por lo que era necesario actuar en forma urgente solicitándose a las autoridades la creación de una "casa de temperancia" para recoger a los alcohólicos.

El tema se toma en serio y así, por ejemplo, en El Obrero Azuayo de 1923, se publicó por segunda vez (ya que la primera publicación data de 1875), traducido al español por Luis Cordero, ${ }^{57}$ un texto del médico marsellés Prosper Despine sobre los efectos del alcohol en el organismo del hombre, en el que se señala que el propósito del opúsculo es el de "infundir en el ánimo de los jóvenes, un profundo horror al vicio de la embriaguez, ${ }^{58}$ que entorpece la inteligencia, corrompe el corazón y debilita el organismo". Tan importante es el tema que se equipara en sus efectos a la irreligiosidad, y se señala, en otro texto del mismo periódico El Obrero Azuayo que:

ninguno es quizá tan eficaz para destruir la vida de la familia y de los pueblos como la propagación horripilante del consumo del alcohol en proporciones tan alarmantes que fueran increíbles si el público no fuera testigo de ello. Y lo peor del caso es que entre la raza indígena, este embrutecedor vicio comienza también a generalizarse ya en las mujeres, que es todo lo que se puede decir. ${ }^{59}$

La producción de aguardiente de caña es un negocio pingüe y "el único que da dinero" pero se insiste en la idea de que se trata de una actividad "inmoral y antipatriótica" reñida con Dios y la justicia. El mismo periódico publicaba, sin embargo, un anuncio de José Félix Medina que ofrece a 1,40

56. "Sobre la embriaguez: Infame, ladrón, asesino de tu propia sangre, dame el PAN para tus hijos, que ya perecen de Hambre y de desnudez infame, infame...", El Heraldo del Obrero Azuayo (12 de abril de 1943): 1.

57. El Obrero Azuayo (1923): s. r.

58. Prosper Despine, De la folie au point de vue philosphique ou plus spécialement psychologique étudiée chez le malade et chez l'homme en santé (París: F. Savy, 1875).

59. "Lo que el alcohol provoca", El Obrero Azuayo (1923): s. r. 
sucres el litro del Aguardiente Jívaro traído de Gualaquiza, a más de otros vinos y licores "de inmejorable calidad".

Se denuncia, por igual, el serio problema que representa el latrocinio, la nula efectividad de las cárceles, que eran más "bien escuelas del crimen", y la presencia de casas de juego y corrupción. El robo de los objetos sagrados es una constante que afectaba tanto a la divinidad como a la sociedad, por lo que era necesario realizar actos públicos de desagravio en caso de producirse.

\section{LAS MUJERES Y SU ÁMBITO MORAL DOMÉSTICO}

La Unión de Mujeres Católicas o UMC poseía su programa particular, en el que se señalaba una práctica constante en las casas de los católicos cuencanos, la presencia de la imagen del Corazón de Jesús "en todos los hogares", y colocada allí por las mujeres. Junto a esto, y dado el ámbito de acción de la mujer que reconoce la UMC, se señalaba la necesidad de que ella se encargase de la devoción y la religiosidad, a través de la práctica de orar los primeros viernes, de rezar el rosario, de impulsar el sentido religioso de las fiestas, de promover la administración de los sacramentos a los enfermos, motivar a los hijos a asistir a misa y a las celebraciones religiosas y difundir la "Guardia Eucarística" y de las "Lámparas del Santísimo". ${ }^{60}$

En concordancia con los principios generales, correspondía a las mujeres las acciones moralizadoras en el entorno doméstico; así removerán de la casa "los cuadros deshonestos", reprobarán "la conducta de los padres de familia que permiten a sus hijas ir de paseo, y, solas, con sus novios", exigirán a las mujeres de servicio "certificados de buena conducta", escogerán nodrizas "sanas de alma y cuerpo", acompañarán a sus hijas al templo y harán "la guerra a las casas de corrupción" ${ }^{61}$

La madre debe intervenir en la educación de los niños, y, dado el conflicto que suponía la educación laica, se constituyó el centro "Madres de Familia" para vigilar las escuelas y colegios y constatar su alineación con "la línea recta de la moral y la disciplina". ${ }^{62}$

60. “Unión de Mujeres Católicas". En Estatutos de la Acción Católica Ecuatoriana (Cuenca: Imprenta del Clero, 1939): 33-48; Programa de Acción Católica..., 1-10.

61. Ibíd., 6.

62. Ibíd. 
Además, es necesario encargarse de proteger a huérfanas y "jóvenes cuya virtud se halla en peligro", ${ }^{63}$ a través de asilos o mediante su colocación como empleadas domésticas, actividad esta última que distaba de protegerlas de la apetencia de los hombres de la casa, ya fueran padres o hijos. Estas jóvenes podían ser violentadas, con relativa frecuencia, con la consecuencia de un embarazo no deseado y el nacimiento de hijos ilegítimos, cuyo padre era registrado como N.N. aunque se conociera bien su nombre.

De acuerdo con el espíritu de las Normas para la organización... antes citadas, en las que los símiles bélicos son frecuentes, se invita a las mujeres a "montar guardia para velar por la moralidad y hacer guerra a las casas de corrupción", entendiendo que la inmoralidad estaba fuera del hogar cristiano. ${ }^{64}$

La Acción Católica debía enfrentar también la moda, planteándose que las señoras y señoritas de prestigio e influjo social establecieron con su ejemplo el traje apropiado que debían ser moderado para evitar la deshonestidad. Esto porque se considera que la moda privaba del pudor a los niños, es una fuente de corrupción, "vuelve liviana a la mujer y es ocasión de pecado" a más de que "sofoca en el corazón de la mujer todo espíritu de sacrificio y la incapacita para el cargo de madre de familia", ${ }^{65}$ y por último, cuando está presente en el templo se convierte en "abominable sacrilegio". Hacia 1930 estuvo plenamente consolidada la moda al estilo europeo, y paulatinamente al estilo estadounidense, y podemos afirmar que los vestidos largos, con corsés, de amplia falda modelada con crinolina, la cola o "categoría", los sombreros de plumas y otros detalles, como las telas de seda colorida, que en su momento causaron escándalo, fueron sustituidos por prendas mucho más ligeras, faldas cortas con canutillos y bordadas de cuentas de vidrio, nuevo maquillaje, propios de los llamados "locos años veinte".

El afán moralizador se extiende a otras "fuentes de perdición", entre las que se cuentan los balnearios, como las piscinas termales de la parroquia Baños a unos ocho kilómetros de Cuenca, y que para ese entonces eran lugar de frecuente visita de los ciudadanos, según puede apreciarse en la publicidad existente y en algunas fotografías de archivo que muestran el uso de sus instalaciones. Aquí, se señala, debe hacerse una campaña no solamente pública, en el púlpito y la prensa, sino también individual que consiste en identificar a las personas inmiscuidas en estas prácticas, para llamarles la atención privadamente. En los balnearios se debe combatir la "inmodestia del vestido, la pésima costumbre de permitir a las señoras y señoritas el que vayan solas

63. Ibíd., 7.

64. Ibíd., 6.

65. Ibíd., 2. 
a los balnearios y más todavía si se trata de la costumbre de dejarlas ir en compañía de sus novios", a más de que se produce una gran confusión por "la mezcla de jóvenes de diverso sexo en el mismo baño". ${ }^{66}$

En este detallado documento se señalaban también las labores previstas para la Acción Católica Juvenil Femenina o ACJF cuya primera referencia es a la labor moral frente a la moda, de la que señala que "se ha de tender a dar a la moderación una tonalidad distintiva de aristocracia, dejando las exageraciones para la gente sin respeto ni prestigio" ${ }^{\prime 67}$ reconociéndose paladinamente el que las normas son exclusivas y excluyentes constituyéndose en ámbito de "distinción" en el sentido bourdiano del término.

Junto a las acciones ya previamente señaladas, como "el desterrar la promiscuidad en los balnearios", se añaden las de celebrar la fiesta de la madre, práctica todavía común en Cuenca, pero también debían "fundar centros de protección obrera en beneficio de las hijas del taller y de las sirvientas", mantener la devoción de los "Sábados de Mayo" y "patrocinar la construcción de la Catedral de Cuenca", un sorprendente encargo a las jóvenes. ${ }^{68}$

\section{Moralización DeSDE EL TEATRO Y LA MúSICA}

Otras propuestas incluyen la organización de veladas dramáticas moralizadoras, una formación integral, la fundación de academias, clubes de deportes y filarmónicas, el desarrollo de conferencias sociales y morales y la celebración de la fiesta del Papa. En Gualaceo, a importantes 40 kilómetros de Cuenca, en el año de 1921, la Sociedad Obreros de San José festeja "la independencia de la provincia" con una velada literario-musical, cuyo número central es la escenificación del drama Quizquiz o Desastre de una Raza, los fondos recaudados se destinan a la Escuela Cristiana de los Hermanos [de la Salle]. En dicho programa, luego del Himno Nacional, cantado por el coro de artesanos que representan el drama, se interpreta el vals "Zanda", el pasodoble "Calderón”, "La Barcarola”, el vals "Mi tesoro", que constituyen otros tantos intermedios, y una pieza final. Los actos del drama son la "vuelta del héroe", "los funerales de Atahualpa y Calicuchima", "la cueva del cóndor en el Chimborazo", "el conquistador Benalcázar y sus compañeros" concluyéndose con "la catástrofe del imperio por la muerte de Quizquiz y la reina Cori-Duchicela". ${ }^{69}$

66. Ibíd., 4-5.

67. Ibíd., 7.

68. Ibíd., 8.

69. "Dramas y vals por la independencia de la provincia", El Progreso (25 de noviembre de 1920): s. r. 
Las acciones propuestas en los programas, que hemos descrito y citado, construyeron una forma particular de ciudadanía desarrollada a partir del concepto, explicado previamente, de la acción del seglar en la sociedad y la superioridad moral de los miembros de la Acción Católica cuya intervención en los ámbitos privados es permanente.

\section{CONCLUSIONES}

Como puede observarse de las finalidades y los planes de la Acción Católica en Cuenca, la recristianización de la sociedad, propuesta por Pío XI, es apenas asumida por sus miembros, salvo la referencia al rezo del Rosario o de los primeros viernes, a la entronización en los hogares de la imagen de Cristo Rey y a escuetas referencias a la solidaridad social, en realidad las actividades se orientaron fundamentalmente a la difusión y profundización de una moral conservadora a través de la construcción de lo que hemos denominado "ciudadanía moral".

América Latina se constituyó durante el primer tercio del siglo XX en un espacio en el que la Iglesia católica pudo desarrollar acciones permanentes de penetración en la sociedad, basándose en el influjo de la Encíclica Rerum Novarum de León XIII de 1891 y el impulso a un catolicismo militante cuya manifestación fundamental fue la Acción Católica.

Si bien la propuesta inicial se refirió a la acción seglar en ámbitos privados, familiares y sociales, el influjo de la Acción Católica sobre las asociaciones obreras es enorme. Bajo una definida concepción del trabajo, y la oposición a cualquier posibilidad de lucha de clases, la Iglesia impulsó la conformación de sindicatos católicos junto a asociaciones obreras bajo su tutela, como sucede en Cuenca con la "Alianza Obrera".

Estas organizaciones tomaron en serio sus finalidades sociales, crearon sistemas de apoyo a los trabajadores y a sus familias, desarrollaron programas de educación y salud y fondos de asistencia económica, como una alternativa a la inacción del estado y a las perspectivas de los empresarios. En este contexto el discurso social católico aparece como una alternativa real a las propuestas, tanto liberal como socialista, y serán los propios obreros y artesanos los que asumirán la defensa de la perspectiva cristiana.

La Iglesia consideraba imprescindible la intervención de los seglares militantes de la Acción Católica en la vida diaria, con el impulso de la moralidad tradicional cristiana enfrentada a los procesos de modernización. Para ello se propusieron planes de acción que se llevaban a la práctica mediante la acción de los seglares que, organizados en núcleos activos, intervinieron en la vigilancia de la vida individual y colectiva en ámbitos como el cine, la 
moda o la literatura. La participación de los activistas de la Acción Católica es intensa y llegó a definir prácticas sociales permanentes que aún son observables en la población católica que participan del concepto de "ciudadanía moral".

Si hasta el primer cuarto del siglo XX numerosos colectivos habían propuesto alternativas a la moral tradicional, y otra visión social, será la intensa y efectiva actividad de la Acción Católica la que transformará a Cuenca en una ciudad conservadora, impidiéndose en esta forma los cambios que se atisbaron a inicios del siglo en los albores de la modernidad.

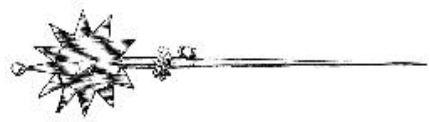

\section{FUENTES Y BIBLIOGRAFÍA}

FUENTES PRIMARIAS

\section{Archivos}

Archivo Histórico de la Curia Arquidiocesana de Cuenca, Ecuador.

Biblioteca "Manuel Muñoz Cueva" de la Casa de la Cultura Ecuatoriana, Núcleo del Azuay. Cuenca, Ecuador.

Biblioteca "Víctor Manuel Albornoz" del Ministerio de Cultura y Patrimonio del Ecuador. Cuenca, Ecuador.

Centro de Documentación Regional "Juan Bautista Vázquez" de la Universidad de Cuenca, Ecuador.

\section{Periódicos y revistas}

El Heraldo del Obrero Azuayo, 1943.

El Obrero Azuayo, 1921-1924.

El Progreso, 1920.

\section{Fuentes primarias publicadas}

Bravo, Manuel J. “Disertación acerca del socialismo". En Discursos leídos en una sesión solemne de la Alianza Obrera del Azuay, 5 de diciembre de 1926. Cuenca: Imprenta del Clero, 1926.

Cordero Dávila, Luis. "Himno Obrero". En Revista El Tres de Noviembre, n. ${ }^{\circ} 119$ (julio de 1952): 91-92.

Estatutos Generales de la Acción Católica Ecuatoriana. Cuenca: Imprenta del Clero, 1939. 
Fernández Pradel, Jorge S. J. Los sindicatos católicos de obreros, segunda edición notablemente aumentada por el presbitero Arsenio Torres. Ibarra: Secretariado Económico Social de la Acción Católica de Ibarra, 1939.

Fontenelle, Monseñor. Pequeño Catecismo de la Acción Católica [traducción de una socia de la FCA]. Cuenca: Tipografía Diasur, 1932.

Haro Alvear, Silvio Luis. Primeras nociones de Acción Católica. Estudio Documentado. Quito: Editorial Ecuatoriana, 1938.

Peralta, José. "El problema obrero". Anales de la Universidad de Cuenca. T. XI, n. ${ }^{\circ} 2$ (abril-junio 1955): 169-182.

Programa de Acción Católica de la Diócesis de Cuenca. Cuenca: Imprenta del Clero, 1941: $1-10$.

Serrano, Manuel de Jesús y Octavio Chacón Moscoso. Normas para la organización y funcionamiento de los centros y núcleos parroquiales de la Acción Católica del Azuay. Cuenca: Imprenta del Clero, 1933.

\section{FUENTES SECUNDARIAS}

Aspe Armella, María. La formación social y política de los católicos mexicanos. La Acción Católica Mexicana y la Unión Nacional de Estudiantes Católicos, 1929-1958. Ciudad de México: Instituto Mexicano de Doctrina Social Cristiana / Universidad Iberoamericana, 2008.

Bauer, Arnold. Somos lo que compramos. Historia de la cultura material en América Latina. Madrid: Taurus, 2002.

Blanco, Jessica E. Modernidad conservadora y cultura política. La Acción Católica Argentina, 1931-1941. Córdoba: Editorial de la Facultad de Filosofía y Humanidades de la Universidad de Córdoba, 2008.

Buriano Castro, Ana. Navegando en la borrasca. Construir la nación de la fe en el mundo de la impiedad, Ecuador 1860-1875. Ciudad de México: Instituto Mora, 2008.

Bustos, Guillermo. “La identidad 'clase obrera' a revisión: una lectura sobre las representaciones del Congreso de Ambato de 1938". Procesos: revista ecuatoriana de historia, n. ${ }^{\circ} 2$ (1992): 73-104.

Cárdenas Reyes, María Cristina. José Peralta y la trayectoria del liberalismo ecuatoriano. Quito: Banco Central de Ecuador, 2002.

Chalco, Maritza Soledad. “Caridad y acción católica en Quito. Discurso y prácticas de la élite en torno a los pobres y obreros en los años treinta". Tesis de maestría, FLACSO Ecuador. 2017. http:/ / repositorio.flacsoandes.edu.ec/xmlui/ handle $/ 10469 / 12439$ ? show $=$ full.

Dután, Holger. "Cuando los curas formaban sindicatos". En Estudios, crónicas y relatos de nuestra tierra, editado por María Rosa Crespo. T. II, 121-127. Cuenca: Casa de la Cultura Ecuatoriana, Núcleo del Azuay, 1992.

Enríquez Capa, Óscar. "Hegemonía y voz autorizada: La cuestión social como espacio de disputa entre subalternos y mandos católicos y conservadores en Quito durante la década de 1930". Tesis de maestría. FLACSO Ecuador. 2015. http: / / repositorio.flacsoandes.edu.ec/ bitstream/10469/9728/2/TFLACSO2015OEEC.pdf. 
Espinoza, Leonardo y Lucas Achig. Breve historia económica de la región cañari. Cuenca: CREA, 1981.

Fernández Soneira, Teresa. Con la estrella y la cruz: Historia de la Federación de las Juventudes de Acción Católica Cubana. Miami: Universal, 2002.

Habermas, Jürgen. Historia y crítica de la opinión pública. Transformación estructural de la vida pública. Barcelona: Gustavo Gili, 1994.

Handelsman, Michael H. El modernismo en las revistas literarias del Ecuador: Ensayo preliminar y bibliografía. Cuenca: Casa de la Cultura Ecuatoriana, Núcleo del Azuay, 1981.

Hidalgo Nistri, Fernando. La República del Sagrado Corazón. Quito: Universidad Andina Simón Bolívar, Sede Ecuador / Corporación Editora Nacional, 2013.

Kingman Garcés, Eduardo. "De la beneficencia de antaño a la auténtica caridad". En Procesos: revista ecuatoriana de historia, n. ${ }^{\circ} 8$ (II semestre 1995-I semestre 1996): 99-117.

Maiguashca, Juan, y Liisa North. "La cuestión regional en la historia ecuatoriana: 1830-1972". En Nueva Historia del Ecuador, editado por Enrique Ayala Mora. Vol. 12. Quito: Grijalbo / Corporación Editora Nacional, 1991.

Martínez Donoso, María de los Ángeles. “Bohemia y vanguardia, el modernismo en Cuenca". En Alma mía. Simbolismo y modernidad. Ecuador 1900-1930, coordinado por Alexandra Kennedy y Rodrigo Gutiérrez, 136-137. Quito: Fonsal, 2014.

Palomeque, Silvia. Cuenca en el siglo XIX, la articulación de una región. Quito: FLACSO Ecuador / Abya-Yala, 1990.

Parente, Pietro, Antonio Piolanti y Salvatore Garofalo. Diccionario de Teología Dogmática. Barcelona: Editorial Litúrgica Española, 1955.

Roux López, Rodolfo de. "Los inciertos parajes de una nueva geografía religiosa en América Latina". L'Ordinaire latino-américain, IPEALT, Université de Toulouse-Le Mirail, n. ${ }^{\circ}$ 200-201 (abril-septiembre 2005): 61-70.

Valenzuela Márquez, Jaime. “Del orden moral al orden político. Contextos y estrategias del discurso eclesiástico en Santiago de Chile". En Máscaras, tretas y rodeos del discurso colonial en los Andes, editado por Bernard Lavallé. Lima: IFEA / PUCP, 2005. 


\title{
La militancia política femenina en la izquierda marxista ecuatoriana de la década de los sesenta: La URME y el PCE*
}

\author{
Women's political activism in Ecuador's Marxist leftwing \\ parties in the sixties: The URME and the PCE
}

Tatiana Salazar Cortez

Universidad Andina Simón Bolívar, Sede Ecuador tatianasc90@gmail.com

DOI: http:/ / dx.doi.org/10.29078/ rp.v0i46.653

Fecha de presentación: 25 de agosto de 2017 Fecha de aceptación: 16 de octubre de 2017

Artículo de investigación

* Este artículo se deriva de mi tesis de maestría intitulada: “La experiencia militante de la Unión Revolucionaria de Mujeres del Ecuador (URME), 1962-1966” (2015-2017), Universidad Andina Simón Bolívar, Sede Ecuador. 
El artículo aborda el conflicto surgido en el seno del Partido Comunista del Ecuador (PCE) durante la década de los sesenta, debido a la amenaza "fraccionalista", producto de la apuesta guerrillera de los grupos disidentes, que miraron en el ejemplo cubano la vía para la revolución. Esta crisis obligó a que el PCE replanteara el lugar de la mujer dentro sus filas y desplegara mecanismos de control desde la lógica jerárquica del Partido y del sistema de valores de su militancia. Por su parte, la apuesta por autonomía configuró una posibilidad organizativa para algunas mujeres de izquierda críticas a la jerarquía partidista y al dominio masculino en su dirección, fomentando así un espacio que generó una agencia política marcada por su diferencia sexual.

Palabras clave: mujeres comunistas, diferencia sexual, militancia femenina, agencia política, revolución cubana,

Partido Comunista del Ecuador.

ABSTRACT

The article examines the conflict emerging in the sixties from the threat of "factionalism" at the heart of the Communist Party of Ecuador (Partido Comunista del Ecuador (PCE) as a result of the bets being placed on guerrilla warfare by dissident groups who looked to Cuba's experience as a model to bring about the revolution. This crisis forced the PCE to rethink its approach to the role of women in its rank and file membership and to draw up control mechanisms based on the Party's hierarchical structure and the value system of its activism. As for the option to provide greater autonomy, it led certain leftwing women who were critical of the prevalence of men in the party's leadership and its hierarchical structure to develop their potential for organizing; this in turn sustained the opportunity for women to develop their own political agency marked by their gender difference.

Keywords: Ecuador, twentieth century, social history, political history, leftwing, communist party, women, gender difference, women's activism 
En una carta enviada a Leonardo Paredes, quien cursaba la carrera de Medicina, su madre Nela Martínez, le relató la disputa surgida en un evento realizado en homenaje al día internacional de la mujer, el 8 de marzo de 1963, entre algunas mujeres comunistas y la dirección del Partido Comunista del Ecuador (PCE). ${ }^{1}$ En el encuentro organizado por la Unión Revolucionaria de Mujeres del Ecuador (URME), el Comité de Unidad por la Paz y la Soberanía, y la Unión Democrática de Mujeres del Ecuador participaron voceras de las organizaciones auspiciantes y militantes de los partidos socialista, socialista revolucionario y comunista. Luisa Gómez de la Torre, Lucía Ochoa, Laura Almeida, Lola de Rodríguez, Laura Ortiz e Hilda Auz establecieron la agenda de la reunión: desarme mundial, lucha por la paz y la negativa al presupuesto destinado a la militarización del país. También debatieron sobre el aporte de Clara Zetkin al movimiento femenino de izquierda y las novedades generadas en el Congreso de la Paz llevado a cabo en Moscú en 1963. Finalmente, cerraron la jornada señalando la necesidad de mantener "una verdadera posición revolucionaria" ante la discriminación de la mujer ecuatoriana y los problemas de la infancia. ${ }^{2}$

El encuentro se vio interrumpido cuando, según URME, miembros de la Alianza Femenina Universitaria (AFU) acudieron al acto con intenciones "saboteadoras". Este encontrón desencadenó enfrentamientos entre las organizaciones de mujeres que se plasmaron en las páginas de las revistas Mañana y Nuestra Palabra, ${ }^{3}$ órgano oficial de URME. Mientras que a niveles organizativos se incentivaron "medidas disciplinarias" por parte del PCE; Nela Martínez, confidencialmente, le comentó a su hijo que las sanciones impuestas por el Comité Central generaron "una ola de rebelión y de protesta" en las filas partidistas, ${ }^{4}$ malestar que fue referido en estos términos: "Porque debes comprender bien que hay dos mundos: el oficial, que lanza consignas estereotipadas, otro, el que pugna por hacer avanzar el día de la liberación, el que lucha en silencio, el que es calumniado, perseguido, maldito" ${ }^{5}$

Por lo visto, el "acto de las mujeres" provocó que Pedro Saad, secretario general del PCE, radicado en Guayaquil, viaje a la ciudad de Quito, sancione

1. "Las mujeres celebran el 8 de marzo, los militares las maltratan”, Mañana, n. ${ }^{\circ} 162,14$ de marzo de 1963: 13; "8 de marzo, jornada de la mujer", Nuestra Palabra, n. ${ }^{\circ}$ 2, marzo 1963: 35.

2. "Las mujeres celebran...", 13.

3. Olga Egas, "La lucha de la mujer ecuatoriana", Mañana, n. ${ }^{\circ} 164,28$ de marzo de 1963: 22.

4. Carta de Nela Martínez a Leonardo Paredes, Quito, 16 de mayo de 1963, Archivo Martínez-Meriguet (AM-M), Correspondencia año 1963.

5. Ibíd. 
a los varones que asistieron al evento de URME y amenace con "medidas disciplinarias" a las militantes Lucía Ochoa de Merino, Piedad Ochoa de Gallegos y Luisa Gómez de la Torre. Finalmente, quien sí fue sancionada con la "ciega rabia negativa" de Saad fue Nela Martínez. ${ }^{6}$

El PCE ratificó la expulsión de Nela después del incidente del 8 de marzo, ya relatado. En reunión plenaria del Comité Central del PCE, el 19 de marzo de 1963, se expulsó a José María Roura, Jaime Galarza Zavala y Nela Martínez. Se argumentó que los dos primeros fueron separados por sus actividades "fraccionalistas"; en cuanto a Martínez, se alegó que nunca pidió su reingreso al Partido luego de que fue apartada por primera vez en 1957; 7 adicionalmente, se la criticó por su "actitud contraria a la línea del Partido" y sus supuestos ataques a la dirección partidista. ${ }^{8}$

Ahora bien, ¿por qué el PCE expulsó a Martínez, Roura y Galarza Zavala? ¿Por qué fueron sancionados los miembros del PCE por acudir a un acto organizado por organizaciones femeninas, democráticas y de izquierda? ¿Cuáles fueron las disputas sobre la "verdadera posición revolucionaria" que llevó a enfrentar el mundo "oficial" con aquel "perseguido"? Este artículo explica los conflictos generados en el seno del PCE debido a la participación de las mujeres en sus filas organizativas en la década de los sesenta. Precisamente, esta coyuntura política puso en jaque a los partidos políticos de izquierda debido a la radicalización de grupos armados. Esta crisis obligó que el PCE reconsidere el lugar de la mujer en sus filas y, con ello, desplegara mecanismos de control desde la lógica jerárquica del Partido y el sistema de valores de su militancia. Por su parte, la apuesta por autonomía configuró una posibilidad organizativa para algunas militantes críticas a la jerarquía partidista y al predominio masculino en su dirección, fomentando una agencia política consciente de su diferencia sexual. ${ }^{9}$

6. Ibíd.

7. Carta de Nela Martínez a Lautaro Garrido, Eduardo González y Wilson Burbano, miembros del Comité Central del Partido Comunista del Ecuador, Quito, 23 de mayo de 1957, AM-M, carpeta de Escritos políticos; Carta del Presidium del VI Congreso del PCE, liderada por Hernán Acevedo y Milton Jijón, a Nela Martínez, Quito, 25 de mayo de 1957, AM-M, carpeta de Escritos políticos.

8. "Resolución de la sesión plenaria del Partido Comunista del Ecuador respecto a la situación de la Sra. Nela Martínez de Mériguet", El Pueblo, 4 de mayo de 1963: 3.

9. Emplearemos la categoría agencia política en la acepción que Joan Scott otorga al reconocimiento que las mujeres tienen de su capacidad e intencionalidad de constituirse como sujetos-agentes activos en los procesos históricos; para ello nuestro planteamiento considera la diferencia sexual como determinante en este proceso como "principio y práctica de la organización social". Joan Scott, "Releer la historia del feminismo". En Las mujeres y los derechos del hombre. Feminismo y sufragio en Francia, 1789-1944 (Buenos Aires: Siglo XXI, 2012), 29; Joan Scott, “Algunas reflexiones sobre género y política”. En Género e 
La historiografía sobre la izquierda ecuatoriana ha sido deudora de un análisis crítico de los partidos políticos, que mayoritariamente los ha vinculado con coyunturas políticas "revolucionarias"; 10 sin embargo, la dinámica interna partidista, las disputas acaecidas y sus mecanismos de funcionamiento han sido ocasionalmente abordados. Las reflexiones de Hernán Ibarra sobre el PCE (pese a que el arco temporal de sus estudios no abarca la década de los sesenta), aportan elementos sobre la organización partidista. Este historiador nos adentra en los cimientos de la crisis que el comunismo internacional sufrió después de la muerte de Stalin en los años cincuenta, con miras al cisma de las décadas subsiguientes. ${ }^{11}$

Por su parte, Adrián Bonilla explora las perspectivas teóricas del discurso político y los quiebres que el marxismo enfrentó por la influencia de las revoluciones china y cubana, ${ }^{12}$ a nivel nacional y regional. ${ }^{13} \mathrm{El}$ autor presenta un horizonte de reacomodos institucionales por los que el PCE atravesó, provocando la creación de una corriente socialista más radical, ${ }^{14}$ que decantó en la emergencia de varias organizaciones críticas a la estructura partidista las cuales, según nuestra lectura, fueron espacios aprovechados por los sectores disidentes, entre ellos las mujeres, quienes fomentaron nuevas apuestas militantes problematizadas desde su diferencia sexual. A no ser por pequeñas

historia (Ciudad de México: Fondo de Cultura Económica / Universidad Autónoma de la Ciudad de México, 2008), 247-255.

10. Coyunturas políticas como la Alianza Democrática Ecuatoriana han atraído a varios historiadores a abordar los grupos de izquierda como un elemento más de una coalición que se configuró alrededor de la figura de José María Velasco Ibarra, en la década de los cuarenta, por ejemplo. Véase, Silvia Vega, La Gloriosa. De la revolución de 28 de mayo de 1944 a la contrarrevolución velasquista (Quito: El Conejo, 1987); Santiago Cabrera Hanna, ed., La Gloriosa, ¿Revolución que no fue? (Quito: Universidad Andina Simón Bolívar, Sede Ecuador / Corporación Editora Nacional, 2016); Germán Rodas Chaves, "La izquierda ecuatoriana en la década de 1960 y la influencia de la Revolución Cubana". En La izquierda ecuatoriana. Aproximación histórica (Quito: Abya-Yala / La Tierra, 2004), 63-93.

11. Hernán Ibarra, "Los idearios de la izquierda comunista ecuatoriana (1928-1931)". En El pensamiento de la izquierda comunista (1928-1961) (Quito: Ministerio de Coordinación de la Política y Gobiernos Autónomos Descentralizados, 2013), 11-64; Hernán Ibarra, “En torno a los fantasmas de la izquierda radical ecuatoriana del setenta". En Memorias del seminario internacional: El legado intelectual y político de Fernando Velasco Abad, coord. por Santiago Ortiz Crespo y Soledad Álvarez Velasco (Quito: FLACSO, 2014), 163-176.

12. Adrián Bonilla, En busca del pueblo perdido. Diferenciación y discurso de la izquierda marxista en los sesenta (Quito: FLACSO / Abya-Yala, 1991).

13. Agustín Cueva, "El marxismo latinoamericano: historia y problemas actuales". En Entre la ira y la esperanza y otros ensayos de crítica latinoamericana (Buenos Aires: CLACSO, 2008 [1987]), 177-200; Fernando Tinajero, “Rupturas, desencantos y esperanzas (cultura y sociedad en el Ecuador: 1960-1985)", Revista Iberoamericana, n. ${ }^{\circ} 144-145$ (julio 1988): 791810.

14. Bonilla, En busca del pueblo perdido..., 2. 
menciones, la producción académica no se ha ocupado de problematizar la particularidad de las militantes de izquierda como agentes críticas de las esferas partidistas a las que pertenecieron.

Si bien hay producciones que recogen la presencia de las mujeres en organizaciones femeninas -liberales, socialistas, sufragistas o feministas $-{ }^{15}$ el estudio sobre las mujeres de izquierda continúa ausente. El trabajo de Rosemarie Terán nos ha permitido adentrarnos en el estudio de la construcción de subjetividades de la mujer de izquierda, el ejemplo de Nela Martínez evidencia escenarios de conflictos que ella enfrentó con la dirección partidista. Adicionalmente, Terán profundiza en los aportes que Martínez hizo en el proceso de construcción del discurso feminista ecuatoriano: "sin abandonar la matriz marxista, ella transforma uno de los postulados centrales de la misma al superponer la categoría género a la de clase, como un eje articulador diferente de la lucha por las consecución de una sociedad más igualitaria". ${ }^{16}$ Por su parte, Silvia Vega aporta al debate una reflexión sobre el "infeliz matrimonio entre marxismo y feminismo". La autora analiza la militancia en la izquierda, fruto de su experiencia, como un espacio hostil y contradictorio. "El divorcio entre la vida cotidiana y la vida política en los partidos de izquierda", según la autora, ahondaron los conflictos surgidos en torno a la militancia femenina, las prácticas discriminatorias y jerárquicas dentro de los partidos, y la subordinación del "problema de la mujer" a la revolución socialista. ${ }^{17}$ Nuestro aporte retoma estos planteamientos y profundiza en cómo la experiencia militante de las mujeres de izquierda se configuró en un andarivel que, si bien fue crítico de la jerarquía partidista, incorporó a su militancia la matriz marxista desde sus experiencias particulares.

Ante este panorama, pretendemos analizar el discurso del PCE publicado en las páginas del órgano oficial de su Comité Central, el semanario El Pueblo. Para ampliar el horizonte del debate hemos acudido a las revistas Mañana y Nuestra Palabra, publicaciones de la época que evidencian las nutridas críticas surgidas entre las emergentes apuestas de izquierda. Finalmente, con la intención de situar la voz femenina, se suma la documentación recabada en el Archivo Martínez-Mériguet (AM-M), repositorio que aportó

15. Ana María Goetschel, "Estudio introductorio". En Orígenes del feminismo en el Ecuador. Antología (Quito: CONAMU / FLACSO / UNIFEM, 2006), 13-56; Nela Martínez Espinosa y Ximena Costales, Yo siempre he sido Nela Martínez: Una autobiografía hablada (Quito: CONAMU / UNIFEM, 2006).

16. Rosemarie Terán Najas, "Historias de mujeres: El 'ser colectivo' de Nela Martínez Espinosa”. En Nela Martínez, Insumisas. Textos sobre las mujeres (Quito: Ministerio Coordinador de Patrimonio, 2012), 9.

17. Silvia Vega Ugalde, "Apuntes para una crítica feminista de la izquierda de los setenta". En Memorias del seminario internacional..., 145-162. 
con fuentes manuscritas, recortes de prensa, hojas volantes, documentos oficiales de las organizaciones y cartas personales.

Este artículo se estructura en tres secciones. La primera aborda la crisis escisionista de la década de los sesenta y la crítica surgida al "deber ser" del comunista, la segunda comprende la lectura masculina de la participación política de las mujeres en las filas del PCE. Finalmente, la tercera parte muestra las disputas generadas por la búsqueda de autonomía de aquellas mujeres que, al fundar URME, exploraron en su diferencia sexual una veta crítica a la lógica masculina que el partido político proyectó sobre su militancia.

\section{EL RESQUEBRAJAMIENTO DEL "DEBER SER" COMUNISTA EN LOS AÑOS SESENTA}

La historiografía ecuatoriana coincide en que la revolución cubana y el fraccionamiento de los partidos comunistas chinos y soviéticos fueron los cismas que minaron la estructura organizacional y política de la izquierda a nivel latinoamericano. ${ }^{18}$ Con ello, también hicieron eco de la crisis que el Partido Comunista Soviético enfrentó después de la muerte de Stalin debido a la autocrítica de Nikita Khrushchev sobre el "culto al líder", ${ }_{19}^{19}$ postura que caló hondo en los partidos comunistas latinoamericanos debido a la larga presencia de dirigentes varones en las direcciones partidistas. Esta afrenta a la estructura jerárquica de los partidos contribuyó a que sea cuestionada, y, con ello, sus postulados políticos. ${ }^{20}$

El Ecuador no quedó exento de dichas circunstancias. La alineación del PCE al Partido soviético consistió en mantener una postura de "estudiada moderación", o de notoria ambigüedad ante la radicalización de los focos guerrilleros identificados con Mao Tse-Tung, que apostaron por la vía armada como mecanismo revolucionario. ${ }^{21}$ Las fuentes estudiadas nos permiten identificar que desde 1967 el PCE emprendió una crítica abierta al Partido Comu-

18. Bonilla, En busca del pueblo perdido..., 36-38; Cueva, "El marxismo latinoamericano...", 187; Tinajero, "Rupturas, desencantos y esperanzas...", 791-810; Ibarra, "Los idearios de la izquierda...", 11-64.

19. Ibarra, ibíd., 11-64; Ugo Pipitone, La esperanza y el delirio. Una historia de la Izquierda en América Latina (Bogotá: Penguin Random House Grupo Editorial, 2015), 12, 137.

20. Pipitone, La esperanza y el delirio..., 141. Pipitone señala que Victorio Codovilla y Américo Ghioldi estuvieron a la cabeza del Partido Comunista Argentino por años; de igual manera, Rodney Arismendi en Uruguay, Carlos Prestes en Brasil y Corvalán en Chile. Pedro Saad en Ecuador permaneció a la cabeza del Comité Central del PCE cerca de 30 años.

21. Eric Hobsbawm, "El tercer mundo y la revolución". En Historia del siglo XX (Barcelona: Crítica, 2010 [1994]), 435; Bonilla, En busca del pueblo perdido..., 2. 
nista Chino. Hasta ese entonces, la lectura sobre las posturas fraccionalistas se asoció con el ultraizquierdismo, consideración que fue proyectada sobre el Partido Comunista Marxista Leninista Ecuatoriano (PCMLE), organización que desde 1964 se consideró crítica del alineamiento soviético. ${ }^{22}$

En el Congreso de 1962 el PCE decidió tomar medidas sobre la arremetida guerrillera, la organización acogió la vía armada como el camino revolucionario para el Ecuador. Pero esta perspectiva radical se vio limitada a los planteamientos tradicionales de los miembros del Comité Central, con Pedro Saad a la cabeza. Hay que recordar que Saad mantuvo la tesis soviética de la formación de una coalición con la burguesía y pequeña burguesía nacionales con la intención de participar en los comicios electorales de 1964, con el Frente de Liberación Nacional. ${ }^{23}$ Posteriormente, Saad apoyó la creación de la Unión Democrática Popular, organización formada en el contexto de las elecciones de 1968. Varias veces el PCE criticó el ultraizquierdismo radical emergente y satanizó sus vinculaciones con el Partido Comunista Chino, acusándolo de divisionista y de antipartidista.

Las rupturas internas suscitadas por los alineamientos hacia la facción china tuvieron un alto costo político para los partidos de izquierda. El caso más evidente fue el que llevó a la formación del PCMLE, fundado por exmiembros del Comité Provincial de Pichincha: Jorge Rivadeneyra y Rafael Echeverría en $1964 .{ }^{24}$ Rivadeneyra y Echeverría tuvieron un altercado con el partido por haber organizado una intentona guerrillera en abril de 1962, dirigiendo a jóvenes de la Unión Revolucionaria de la Juventud Ecuatoriana (URJE) a los alrededores del río Toachi, ${ }^{25}$ acción que ocasionó su expulsión en 1964 y la negativa del PCE a apoyar la causa armada. ${ }^{26}$ Sobre los radica-

22. Bonilla, ibíd., 56; Cueva, “El marxismo latinoamericano...", 178.

23. Los lineamientos del Partido fueron modificados en el VII Congreso del PCE, llevado a cabo en 1962, en el que se estableció el Frente de Liberación Nacional como la plataforma de alianza de clases idónea para conseguir la revolución social. "Estatutos del Partido Comunista del Ecuador", El Pueblo, 24 de marzo de 1962: 1, 4-7.

24. "Resolución del Comité Central del Partido Comunista del Ecuador. Expulsión definitiva de Rafael Echeverría y Carlos Rodríguez", Guayaquil, 28 de marzo de 1964, AM-M, carpeta Escritos políticos; “Resolución del Comité Central del Partido Comunista del Ecuador, divulgado por el Comité Provincial de Pichincha del Partido Comunista del Ecuador", Guayaquil, 3 de abril de 1964, ibíd.

25. La noticia de la guerrilla del Toachi, en Santo Domingo, tuvo una significativa repercusión mediática. Tanto la prensa partidista como la prensa de gran tiraje cubrieron la noticia. La intentona guerrillera fue disuelta a los pocos días por los paracaidistas de las Fuerzas Armadas del Ecuador, en abril de 1962. Véase "iLibertad para las muchachas guerrilleras!, Quito, 24 de mayo de 1962", Mañana, n.o 122, 7 de junio de 1962: 21; "Foro público sobre las guerrillas del Toachi", Mañana, n. ${ }^{\circ}$ 122, 7 de junio de 1962: 21.

26. "Denunciamos a los falsos revolucionarios", El Pueblo, 22 de junio de 1963: 7; “Jaime Galarza?...", ibíd., 7; “Vida del Partido”, El Pueblo, 22 de junio de 1963, 8. 
les y aventureros guerrilleros, el partido sostuvo que "se trata pues, de un grupillo sin arraigo, sin organización, y sin principios, que se cubre con una fraseología ultraizquierdista para tratar de engañar a los incautos", que buscaba "conseguir sus fines de corrupción con los escisionistas internacionales, [es decir] los dirigentes del Partido Comunista de China". ${ }^{27}$

El Partido Socialista constató, también, el desprendimiento de una facción radical de sus filas. En marzo de 1963 se fundó el Partido Socialista Revolucionario del Ecuador (PSRE), dirigido por Manuel Agustín Aguirre. ${ }^{28}$ Del mismo modo, a lo largo de toda la década de los sesenta, se crearon nuevos movimientos independientes que enarbolaron propuestas más radicales. El Movimiento de Izquierda Revolucionaria (MIR), Vencer o Morir (VM), URME, entre otros, fueron ejemplos de ello. ${ }^{29}$

El PCE radicalizó sus medidas disciplinarias ante la emergencia de los grupos "ultraizquierdistas", expulsó a varios militantes y fortaleció su normativa interna -reformó sus estatutos en 1962 y 1968- para evitar cualquier brote no alineado con las decisiones del Comité Central. ${ }^{30}$ Pero, ¿cuáles fueron los alegatos a los que el partido recurrió para expulsar a los "divisionistas"? ¿Acaso rechazaban la propuesta armada y por ello los excluyeron del partido? ¿O el cuestionamiento del "deber ser" del comunista se convirtió en una afrenta peligrosa?

En nuestro criterio, el problema que enfrentó el PCE en los sesenta se debió a su actitud ambigua ante la incorporación de nuevas propuestas de militancia. Ejemplo de ello fue el conflicto suscitado con los urjistas. La estructura orgánica del partido contemplaba una fracción de militancia juvenil: la Juventud Comunista. Esta organización tuvo su propio estatuto y órgano de publicación; a pesar de que, retóricamente, era una estructura independiente, respondía a la dinámica jerárquica del partido, es decir, estaba sujeta a verticalidad de las decisiones del Comité Central. En 1959 el PCE apoyó

27. "Los fraccionalistas, un grupillo de aventureros. Resoluciones del C.C. del Partido Comunista del Ecuador", ibíd., 28 de enero de 1967, 4, 7.

28. Manuel Agustín Aguirre, "Introducción". En Carlos Marx, en homenaje al centenario de su muerte (Cuenca: Universidad de Cuenca / IDIS, 1983), 57-62.

29. Bonilla, En busca del pueblo perdido..., 56-58. El autor señala que este nuevo escenario permitió expresar espacios políticos de participación distintos. El debate interno se diversificó bajo tres aristas. En primer lugar, la tendencia comunista, heredera de la tradición cominteriana; la segunda, una escisión maoísta con una perspectiva comunista nacional; $\mathrm{y}$, finalmente, una corriente socialista radical.

30. "A todos los organismos y militantes del Partido y de la Juventud Comunista en la provincia de Pichincha", Guayaquil, 26 de junio de 1963, AM-M, carpeta Pronunciamientos políticos varios, n. ${ }^{\circ} 2$; "Resolución del Comité Central del Partido Comunista del Ecuador. Expulsión definitiva de Rafael Echeverría..."; "Resolución del Comité Central del Partido Comunista del Ecuador, divulgado por el Comité Provincial de Pichincha...". 
la creación de URJE, ${ }^{31}$ organización presidida por Jaime Galarza y Édison Carrera. Después de la intentona guerrillera de los urjistas, anteriormente comentada, el desmembramiento de la izquierda marxista ecuatoriana fue inevitable. Los sectores juveniles y los militantes críticos fugaron de la estructura partidista a nuevas plataformas más horizontales.

Sabemos que el PCE rechazó cualquier asociación con los guerrilleros; es más, en el VII Congreso del Partido, realizado en Guayaquil del 9 al 13 de marzo de 1962, reformó su Estatuto y el Programa del partido con la intención de aclarar su postura ante la lucha armada, y buscó contener la presencia de las minorías e impuso al "centralismo democrático" como inapelable. ${ }^{32}$

Uno de los principales cambios realizados en el Programa del partido fue su postura ante la apuesta armada. Este recurso fue incluido en los estatutos en los años posteriores a la revolución cubana y a la escisión chino-soviética. El Programa especificaba que "el Partido Comunista del Ecuador ha afirmado siempre y lo sostiene ahora, que la vía de la revolución ecuatoriana es la NO PACÍFICA, ya que las masas se verán obligadas a recurrir a la violencia para defender con la acción la causa del proletariado". ${ }^{33}$ No obstante, precisaron que la vía no pacífica dependería de las condiciones materiales de la sociedad ecuatoriana. ${ }^{34} \mathrm{Si}$ bien en los textos oficiales de la organización se planteó la posibilidad de la lucha armada, el hecho de estar alineados hacia el bloque comunista soviético le llevó a considerar como divisionistas a los militantes interesados en plantear estos puntos del debate dentro del pleno del Partido. Específicamente, en el Estatuto de 1962, con la intención de evitar que se creen minorías en las filas comunistas, el PCE dictaminó que las minorías estaban en la obligación de acoger las decisiones tomadas por los organismos superiores. ${ }^{35}$ Es así que se propuso, en el artículo 12, que "se evite que una minoría pueda llegar a imponer una discusión inacabable que impida la realización de las tareas del Partido o que sirva de pretexto para la formación de grupos o fracciones". ${ }^{36}$

Las medidas adoptadas por la organización sobre el problema divisionista se ahondaron durante toda la década. El semanario oficial del Comité

31. URJE se formó con la participación de las juventudes socialistas, cefepistas y comunistas de la provincia del Guayas, en contacto con otras organizaciones juveniles del país. Véase "Declaración de Principios de Unión Juventudes Revolucionarias Ecuatorianas (URJE)", El Pueblo, 13 de febrero de 1960: 4.

32. "Estatutos del Partido Comunista...", 4-7.

33. "La vía de la Revolución Ecuatoriana", El Pueblo, 6 de julio de 1963: 3. Énfasis en el original.

34. Ibíd.

35. "Estatutos del Partido Comunista...", numeral "d", art. 8.

36. Ibíd., art. 12. 
Central del PCE, El Pueblo, notificó cada mes a sus lectores sobre expulsados y militantes apartados temporalmente debido a faltas disciplinarias. Finalmente, el Comité Central estableció que los militantes no podían tener ningún tipo de relación con aquellos considerados "oportunistas corrompidos", con la intención de evitar cualquier tipo de "contagio". ${ }^{37}$

Ante el fortalecimiento del centralismo democrático y del internacionalismo proletario como sus normativas organizacionales, el PCE aseguró la conformación de una estructura jerárquica impositiva que consideró la disciplina, lealtad y el pago puntual de deudas como la triada del "buen comunista". ${ }^{38}$ Adicionalmente, todo militante debía perseguir los lineamientos políticos del partido: lucha antioligárquica, antifeudal y antiimperialista. ${ }^{39}$ Todos aquellos que dudaban sobre el alineamiento a los designios "de la mayoría" fueron puestos en el ostracismo. Ahora bien, en este contexto social, ideológico y de interpelación por el que atravesó la izquierda marxista, es preciso preguntarnos ¿cuál fue la lectura que el PCE tuvo de la participación de las mujeres en sus filas?

Ante un horizonte hostil hacia las nuevas ideas "ultraizquierdistas y fraccionalistas", el partido se vio notoriamente mermado de miembros activos. Por ello, desde 1966, el Comité Central decidió desplegar campañas de reclutamiento y robustecimiento de la organización. Bajo esta consideración, las mujeres pasaron a jugar un papel fundamental en la lucha revolucionaria planificada de masas.

\section{"El PROBLEMA DE LA MUJER" EN LA PERSPECTIVA DEL PCE}

En los años anteriores a la revolución cubana, el PCE planteó la posibilidad de crear un programa de trabajo con las mujeres de sus filas; sin embargo, la iniciativa de formular un proyecto de trabajo femenino de masas tuvo que esperar hasta la segunda mitad de la década de 1960 para que fuera incorporado a su plan de trabajo. La incidencia de la revolución cubana, en términos de mirar a la mujer como agente activo de la ansiada revolución proletaria, le brindó al PCE una nueva lectura sobre el "problema de la mujer". Del mismo modo, la lucha codo a codo de las guerrilleras vietnamitas con sus compañeros y el reconocimiento "retórico" de la mujer soviética como igual al hombre,

37. "Vida del Partido".

38. "Estatutos del Partido Comunista...", art. 1; "La calidad del militante", El Pueblo, 4 de enero de 1969: 4.

39. “Estatutos del Partido Comunista...", Capítulo primero. 
se convirtieron en ejemplos obligatorios para todos los militantes activos. ${ }^{40}$

Hasta el final de la década de los cincuenta, se asoció a las mujeres comunistas con el trabajo por la paz, propio del debate de la posguerra; con la defensa de la infancia; y con la responsabilidad revolucionaria de redimir a otras mujeres con la abolición del capitalismo. Estos tres ejes se plasmaron en actividades específicas en las que fueron enroladas las comunistas. Proyectos que fueron consecuentes con la lectura dominante de la organización y sujetos a la retórica revolucionaria.

Además del saludo anual a todas las mujeres ecuatorianas por el día internacional de la mujer, las únicas referencias que el semanario El Pueblo reprodujo entre 1950 y 1970 fueron noticias sobre los congresos internacionales de mujeres. En 1954, por ejemplo, expusieron varios artículos que abordaron la problemática femenina abordada durante el Congreso Internacional de Mujeres realizado en Copenhague. Si bien reflexionaron sobre la igualdad y los derechos laborales de la mujer, ratificaron que esta pertenecía al hogar y debía luchar por el bienestar familiar ante un ambiente mundial amenazado por la guerra. ${ }^{41}$ Asimismo, en el contexto de la reunión de la Conferencia Internacional de la Infancia desarrollada en Viena, el PCE recomendó a sus militantes "la defensa de la infancia" y la creación de comités nacionales con la intención de demandar del Estado mayor previsión en temas de maternidad y cuidado. ${ }^{42}$ Las mismas referencias se reprodujeron en los años posteriores. Sin duda, el hecho de que Pedro Saad, secretario general del PCE, haya aprobado las actividades de la Federación Democrática Internacional de Mujeres (FDIM), organismo cercano a la izquierda soviética, dio luz verde para que se publiquen en El Pueblo artículos sobre sus congresos y líneas de trabajo. Principalmente, las noticias referentes al FDIM se centraron en la necesidad de la unidad de las mujeres, su rol en la familia, en el trabajo, en la sociedad, en la lucha por la independencia nacional, la defensa de la democracia, la solidaridad con el pueblo vietnamita y la lucha por la paz. ${ }^{43}$

40. Las referencias que el PCE acogió como modelo ideal se basaron en la mujer cubana revolucionaria, considerada como el "ejemplo de mujer latinoamericana"; la vietnamita, quien "lucha junto a sus hijos, maridos, hermanos, novios por la libertad de su Patria"; y las hazañas de Valentina Tereshkova, cosmonauta. Asimismo, exhortaban a que las mujeres del partido lean la revista Mujer Soviética, distribuida por el Comité Central. "Saludamos en el día internacional de la mujer", El Pueblo, 4 de marzo de 1967: 5.

41. "Las tareas de las mujeres en el momento actual", El Pueblo, 16 de enero de 1954: 4.

42. "Las mujeres deben defender la infancia y la lucha por la paz", El Pueblo, 23 de enero de 1954: 4.

43. "Llamamiento a las mujeres del mundo entero", El Pueblo, 3 de febrero de 1968: 3, AM-M, carpeta Periódicos 40 /50/60. También se informó sobre la reunión del Consejo del FDIM en Checoslovaquia del 14 al 17 de octubre de 1967, y sobre la convocatoria al nuevo Congreso que se llevaría a cabo del 1 al 5 de diciembre de 1968, en Finlandia. 
Durante el resto de la década de los cincuenta, las referencias a las mujeres fueron mínimas. El tratamiento de la problemática femenina fue tangencial a los intereses del partido. Es así que la lectura sobre la participación femenina en sus filas se centró en mirar al debate internacional como un modelo, pero, a su vez, sirvió también para legitimar estereotipos tradicionales sobre la figura femenina en el hogar, abocada a la familia; en especial al cuidado de la infancia, ratificando así el modelo de mujer maternizada. ${ }^{44}$

La década de los sesenta planteó al PCE dos problemáticas con las que tuvo que lidiar. Por un lado, la crisis fraccionalista y, por otro, el reconocimiento de las mujeres como agentes activas en la causa revolucionaria, marcado por la experiencia cubana. Es así que el Congreso de 1962 incorporó en el orden del día el debate del "Congreso Americano de Mujeres, a reunirse en La Habana el 26 de julio de 1962" y la postura que iba a tener su representante: Alba Calderón. ${ }^{45}$ Años después, en 1967, el PCE expuso un plan de trabajo denominado "Tareas en el movimiento de mujeres", ${ }^{46}$ que se presentó en el contexto de la campaña de robustecimiento de la filas del Partido. Finalmente, recién en el "Programa del Partido Comunista del Ecuador" de 1968, se incluyó como eje central la solución a las "múltiples discriminaciones que pesan sobre las mujeres ecuatorianas". ${ }^{47}$ Entonces, ¿cuál fue la estrategia desplegada por el PCE ante la participación de las mujeres en un contexto políticamente cambiante?

Nos parece pertinente partir del hecho de que el PCE buscó establecer espacios de participación para las mujeres, siempre y cuando estuviesen tutelados por el Comité Central. El fraccionamiento fue un temor que debió sortear el Partido. Es así que, a pesar de haber contado con reflexiones presentadas por algunas mujeres comunistas en la década de los cincuenta, ${ }^{48}$ es- $^{-}$

44. Natalia Casola, “Con ' $m$ ' de 'mamá': Las militantes comunistas y la Unión de Mujeres Argentinas durante la segunda mitad del siglo XX", Amnis, n. ${ }^{\circ} 13$ (2014): 1-9.

45. "Informe de actividades", El Pueblo, 17 de abril de 1962: 5-12.

46. "Tareas en el movimiento de mujeres", El Pueblo, 18 de febrero de 1967: 5, 7. Este texto tuvo varias versiones y se nutrió de proyectos planteados por mujeres comunistas los años anteriores.

47. Programa del Partido Comunista del Ecuador (Guayaquil: s. r., 1968), 7-8, 38.

48. Conocemos tres textos que fueron presentados al pleno del Comité Central entre 1954 y 1955. Los dos primeros fueron expuestos por la Comisión Nacional de Mujeres del PCE para la formación de la Organización de las Mujeres Democráticas y, al siguiente año, el "Proyecto de plan de organización de la Federación Democrática de Mujeres Ecuatorianas". Asumimos que la autoría fue de Luisa Gómez de la Torre, con la colaboración de Nela Martínez. Asimismo, Pedro Saad y Rafael Echeverría presentaron un "Plan de organización para el trabajo entre las mujeres", que asumimos fue posterior a los dos anteriores. Véase, "Plan de trabajo que la Comisión Nacional de Mujeres presenta al Comité Central del Partido para la Organización de las Mujeres Democráticas", s. f., AM-M, carpeta Mujeres; "Proyecto de plan de organización de la Federación Democrática de Mujeres 
tos esfuerzos fueron considerados recién una década después. Esto no quiere decir que la militancia femenina en las filas partidistas no fuese posible hasta ese entonces; la diferencia que percibimos es que la representación de la mujer que produjo la experiencia cubana permitió transgredir internamente la percepción que se tenía del sujeto-agente femenino.

La iniciativa del trabajo femenino no fue un fenómeno único y posterior a la revolución cubana. Anteriormente, las comunistas propusieron la creación de una organización de mujeres que estuviese vigilada por la dirigencia. Ejemplo de ello fue la propuesta que Luisa Gómez de la Torre presentó sobre la creación de la Federación Democrática de Mujeres Ecuatorianas, ${ }^{49}$ proyecto que fue apadrinado por Pedro Saad y Rafael Echeverría en los años posteriores. El texto presentado por el Comité Central señalaba que: "Para realizar el trabajo organizativo de masas, las camaradas deberán recordar que nuestra unidad se hace con dos tipos de mujeres: un sector politizado, o de fácil politización, entre las que se cuentan socialistas, liberales y mujeres con alguna experiencia en trabajos políticos anteriores, y otro, el gran sector de mujeres que tenemos que ganar para las luchas"..$^{50}$

Sobre el tipo de aproximación a estos grupos "de fácil politización", el partido destacó que se debía evitar crear suspicacias que decanten en campañas de difamación del partido. La amenaza fraccionalista obligó a que el PCE evite, a toda costa, "brotes de sectarismos entre las comunistas, tratando de ganar hegemonía política mecánica [d]el movimiento y no como resultado de su acción". ${ }^{11}$ De este modo, la organización iba a ser vigilada desde la dirección del Comité Central. Finalmente, sobre el trabajo para lograr la unidad del internacionalismo proletario, la propuesta señalaba que la organización debía seguir los planteamientos de la FDIM; mientras que dentro de la estructura interna se debía crear la Federación Democrática Nacional de Mujeres.

El texto de Saad y Echeverría brinda dos lecturas sobre la participación femenina. Primeramente, postularon que el trabajo con las mujeres no debía fomentar sectarismos. En segundo lugar, se estableció que la dirección del

Ecuatorianas", Quito, 15 de agosto de 1955, AM-M, Fondo Luisa Gómez de la Torre; Pedro Saad y Rafael Echeverría, "Plan de organización para el trabajo entre las mujeres", s. f., AM-M, carpeta Leyes, estatutos, reglamentos.

49. El proyecto de Luisa Gómez de la Torre se centró en la organización de la Federación de Democrática de Mujeres en Pichincha; una vez establecida esta plataforma, se buscaría irradiar su influencia en otras provincias. También es llamativo el mapeo que hacen de las organizaciones que la Federación debía acoger. Véase, "Proyecto de plan de organización de la Federación...".

50. Saad y Echeverría, "Plan de organización...".

51. Ibíd. 
partido iba a ser el organismo de vigilancia de la nueva plataforma femenina; es decir, el Comité Central sería el encargado de tutelar las actividades realizadas, sus postulados y lineamientos; similar a la propuesta de adhesión a los principios de la FDIM. Conocemos que a la cabeza de la Unión Democrática de Mujeres Ecuatorianas, nombre que adoptó el proyecto del frente de mujeres que fue apoyado por el PCE, se encontró la escritora socialista Raquel Verdesoto de Romo. ${ }^{52}$ Del mismo modo, Luisa Gómez de la Torre fue, paralelamente, representante de la Unión, de URME y del PCE. ${ }^{53}$

En el contexto de la realización de la Segunda Conferencia Sindical Internacional de 1963, el semanario El Pueblo publicó reflexiones sobre la relación de la "doble explotación" femenina, "como mujer y como trabajadora". El análisis de la situación de las mujeres se centró en la desigualdad salarial, la falta de atención del Estado hacia la maternidad y el cuidado de la infancia, ${ }^{54}$ enfatizando en la diferencia sexual como elemento de discriminación. Sobre la causa femenina como parte de la lucha de clases, señalaron:

La clase obrera incluye en su programa la reivindicación de los derechos de la mujer. La discriminación de las mujeres es una característica de los regímenes sociales divididos en clases. Las clases dominantes menosprecian a la mujer. La ofenden cuando la colocan en el sitial de, como dijo un escritor, "mamífero de lujo". Siendo, como es, la discriminación contra la mujer una condición de clase, la lucha por reivindicar a la mujer, por defender sus derechos de mujer, por acabar con la odiosa discriminación contra ella, es lucha de clases, es parte de la lucha de clases, de la lucha que encabeza el proletariado. .5

La nota reconoce la particularidad de la discriminación hacia las mujeres fomentada por las condiciones de clase. También establece que es un "mamífero de lujo", o un "adorno para el hogar" de los burgueses, mientras que identifica a la revolución "encabezada por el proletariado" como el medio revolucionario para la mujer. ${ }^{56} \mathrm{Si}$ bien se percibe una mayor reflexión sobre la discriminación, al ser apadrinada por los postulados clasistas, las demandas femeninas pasaron a ser un tema de superación de las divisiones

52. “Unión Democrática de Mujeres Ecuatorianas", El Pueblo, 26 de noviembre de 1960: 8 .

53. Tinajero, "Rupturas, desencantos y esperanzas...", 791-810; "Solidaridad con Cuba de URME, mensajes del Comité de Unidad por la Paz y la Soberanía a Río", Nuestra Palabra, n. 3 (abril 1963): 19.

54. "Hacia la II Conferencia Internacional de la Mujer Trabajadora", El Pueblo, 5 de enero de 1963: 3.

55. "La mujer trabajadora en la lucha de clases", El Pueblo, 1 de mayo de 1966: 4. Énfasis añadido.

56. "La mujer en la sociedad capitalista", El Pueblo, 2 de diciembre de 1967: 9. 
de clase; es decir, para el PCE la única vía de reivindicación de las mujeres debía ser la del proletariado. ${ }^{57}$

En el contexto de la campaña de robustecimiento del PCE, en 1967, el Comité Central publicó varios artículos sobre la "problemática femenina" con la intención de establecer un plan de trabajo para las mujeres. De este modo, se buscó incorporar a sus filas a jóvenes, a trabajadores de fábricas quienes eran "más de la mitad de la población". El Comité se refirió en los siguientes términos al proyecto:

es tarea de los comunistas organizar a las obreras, campesinas, empleadas, amas de casa, estudiantes, habitantes de barrios de las urbes y a quienes viven en las poblaciones pequeñas, intelectuales, profesionales a través de las luchas por sus reivindicaciones concretas; y mediante esas movilizaciones específicas, desarrollándolas, ampliándolas, elevarlas al nivel de las luchas generales de las masas populares. ${ }^{58}$

A pesar de que el proyecto político de masas femenino tenía una clara impronta clasista, el PCE señaló que existían planteamientos extraños a los que perseguía el proletariado; por ello, se propuso una hoja de ruta sobre qué actividades se debían desarrollar, con qué fines y quiénes serían los encargados de liderarlas. Asumimos que la precaución que tomó el partido se debió a la emergencia de planteamientos feministas en sus filas. Denunciaron, que "subsisten prejuicios en la medida en que las ideologías extrañas al proletariado subsisten en nuestra militancia, de allí que su enfrentamiento correcto plantee también la permanente lucha doctrinaria e ideológica en el seno del PCE". ${ }^{59}$ Este enfrentamiento ideológico fue posteriormente expuesto por Pedro Saad ante el Activo de Mujeres Comunistas reunido en Guayaquil el 2 de julio de $1972 .{ }^{60} \mathrm{El}$ texto titulado "El trabajo del Partido entre las mujeres" pone en claro la advertencia que el PCE hizo a las comunistas sobre la amenaza reformista del feminismo burgués. El "problema de las mujeres", denominación formulada por el secretario general, buscaba ser resuelto por la lectura masculina que hizo el PCE. Saad señaló: “Debemos tener presente que el movimiento de mujeres que nosotros impulsemos no puede ser un movimiento de contenido burgués feminista, sino que debe tener un contenido revolucionario que con-

57. Vega, “Apuntes para una crítica feminista...", 149, 156.

58. "Sobre el trabajo entre las mujeres", El Pueblo, 11 de febrero de 1967: 3, 5.

59. "El trabajo del Partido entre las mujeres. Informe presentado al Activo de Mujeres Comunistas reunido en Guayaquil el día 2 de julio de 1972, a nombre del Ejecutivo del Comité Central del Partido Comunista del Ecuador", s. r.

60. Ibíd. 
duzca a las mujeres, en especial a la mujer obrera, campesina y de las masas populares a la acción revolucionaria junto al hombre" ${ }^{61}$

El PCE en 1972 destacó que el trabajo del Partido iba a incorporar a las amas de casa, campesinas, obreras y maestras. Aducimos que el intento propuesto durante la década de los sesenta no fue fructífero; por ello plantearon la creación de un nuevo frente de mujeres que rechace la "proliferación de tendencias feministas en el Partido y de las ideas de superioridad de la mujer" en los años posteriores. ${ }^{62}$

El informe de Saad también recalcó el trabajo internacional de la organización. Hay que tener presente que, para el PCE, en las décadas de los cincuenta y sesenta, fue su referente sobre el movimiento femenino. En 1972 se advirtió que la Federación había asumido una "tendencia un poco reformista", 63 debido a ello, los grupos de mujeres ecuatorianas, tutelados por el Partido, debían rectificar dicha desviación burguesa y feminista. La postura que el PCE tomó en torno al trabajo con las mujeres no consideró al feminismo como una amenaza con características propias que hayan sido problematizadas. La única referencia que se hizo (al menos en el arco temporal de nuestro estudio) aludió a su carácter burgués, con una connotación claramente despectiva vinculada al feminismo liberal prosufragista y emancipatorio que se radicalizó a nivel mundial en el período entreguerras.

Días después de las reflexiones publicadas en 1967, el semanario El Pueblo editó un plan de trabajo en el que especificó los pasos para la organización femenina. ${ }^{64}$ En primer lugar, las actividades organizativas tenían como propósito impulsar el trabajo entre las mujeres obreras, campesinas, estudiantes, maestras, empleadas fiscales, municipales, bancarias, comerciales, empleadas domésticas, mujeres de barrio, profesionales e intelectuales. De este modo, el partido pudo cooptar a las organizaciones existentes en varios frentes, $y$, sobre todo, promover la creación de comités de la Unión Democrática de Mujeres como filiales adheridas a la coalición de izquierda que se había presentado a la contienda electoral de 1968. Es así que pretendieron potenciar las organizaciones femeninas en la Unión Nacional de Educadores (UNE), en la Confederación de Trabajadores del Ecuador (CTE), agrupar a las campesinas en las comisiones de asuntos femeninos de la Federación Ecuatoriana de Indios (FEI), en la Federación de Estudiantes Secundarios del Ecuador (FESE); y reactivar la Asociación Femenina Universitaria (AFU), fundada bajo la tutela del PCE en $1952 .{ }^{65}$

61. Ibíd., 13.

62. Ibíd., 49.

63. Ibíd., 50.

64. "Tareas en el movimiento...", 5, 7 .

65. Estatutos de Asociación Femenina Universitaria del Ecuador, filial de Quito (Quito: Imprenta de la Universidad, 1952). 
El proyecto incidió en la reestructuración institucional, para ello el PCE buscó debatir sobre los "problemas que afectan a las mujeres" con la intención de advertir a los militantes sobre cuáles debían ser las tareas en el frente de mujeres, siempre y cuando tengan como objetivo primordial el fortalecimiento de la Unión Democrática de Mujeres. También se estableció que la comisión nacional funcionaría bajo la dirección del Comité Central. En este sentido, con la intención de evitar cualquier tipo de síntoma fraccionalista, se debían "organizar células femeninas siempre y cuando las condiciones objetivas lo determinen, ligadas a sectores de masas y de acuerdo a las necesidades del PCE". Sobre los nuevos espacios de organización, se propuso la creación de comisiones de trabajo mixtas (hombres y mujeres) que busquen trabajar en las tareas establecidas en los organismos provinciales y zonales. Igualmente, cada célula debía fomentar "la incorporación de mujeres, hijas, hermanas, de los militantes a la vida del Partido y de la Juventud". ${ }^{66}$ Es así que se estableció el trabajo conjunto entre la Juventud Comunista y el frente femenino, siempre vigilados desde el Comité Central.

Finalmente, el partido presentó trece puntos que delinearon el proyecto de trabajo con las mujeres. Se plantearon medidas para la consecución de derechos laborales en términos de igualdad con los hombres (salario, enseñanza, rebaja del impuesto a la renta e igualdad ante la ley), afiliación al Seguro Social y entrega de tierras a campesinas. Tampoco perdieron de vista los postulados vinculados a la maternidad y el cuidado de la infancia, ${ }^{67}$ planteamientos que fueron elaborados desde la necesidad de potencializar la inclusión de la mujer como fuerza productiva y garantizar su maternidad.

Ante este horizonte político salpicado de fraccionalismos, afrentas internas y cuestionamientos hacia la organización partidista, se entiende de mejor manera el encontrón entre las mujeres comunistas de URME y miembros de AFU, la sanción del PCE a sus militantes y la ratificación de la expulsión de Nela Martínez y de los otros dos "fraccionalistas". ${ }^{68}$ Ahora bien, nos hemos adentrado en la visión "oficial" del PCE sobre la participación femenina en sus filas, la crisis escisionista y los temores que esta coyuntura generó en la organización. La contraparte de este intento de control fue asumida por un grupo de mujeres que cuestionó estas disposiciones y fundamentó, desde su situación de discriminación por su diferencia sexual, apuestas autónomas en plataformas democráticas de izquierda. La siguiente sección presenta las

66. "El trabajo del Partido...".

67. "Tareas en el movimiento...", 5, 7 .

68. José María Roura fue apartado del partido debido a su vinculación con el movimiento comunista chino. Jaime Galarza se consideró un izquierdista independiente. Véase “La revista Mañana y sus desvergonzados editores”, Mañana, n. . 225, 11 de enero de 1968: 23. 
disputas generadas en torno a los planteamientos del PCE y la Unión Revolucionaria de Mujeres del Ecuador.

\section{Conflictividad ANTE LA AUTONOMÍA}

El altercado con AFU y con las mujeres "comunistas" del PCE no quedó ahí. URME denunció que, en un posterior acto en Guayaquil en el que se pretendía debatir sobre la situación de la mujer en el Ecuador y sobre su trabajo en relación a la lucha por la paz, ${ }^{69}$ "un grupo de mujeres autotituladas comunistas se ha reunido [...] para realizar un llamado 'activo' que en realidad ha sido activismo, tanto que la gran consigna dada es la de SABOTEAR, NO LEER, NI COMPRAR, NI DISTRIBUIR 'NUESTRA PALABR A'", 70 órgano de difusión de la organización. El altercado avivó el enfrentamiento entre URME y el PCE, ya que las militantes acusaron al partido de haber patrocinado el sabotaje del acto. Asimismo, URME se sirvió de la disputa para recalcar que su trabajo revolucionario sí era consecuente con las tesis antiimperialistas de la izquierda internacional, mientras que el PCE no se mantenía a la vanguardia social y, por el contrario, hacía "coro al imperialismo" ${ }^{71}$ Es más, en días anteriores URME ratificó que "aún en los organismos donde se plantea como tesis fundamental la liberación social y nacional, es corriente la discriminación a la mujer" ${ }^{72}$ Ante estos evidentes enfrentamientos, la militancia femenina se vio en abierta contienda con el partido no solo por la oposición a las medidas coercitivas desplegadas, sino por su crítica a la estructura patriarcal, jerárquica y discriminatoria.

La pugna coyuntural se transfiguró en contienda política e ideológica para URME y el PCE. La crítica a la cual Martínez se vio expuesta se radicalizó debido a su postura contraria a la figura del secretario general y al principio jerárquico del partido. La "renegada Nela Martínez", un epíteto que se le atribuyó en las páginas de El Pueblo, se prolongó a lo largo de toda la década de los sesenta por las continuas desavenencias generadas entre ella y Saad. ${ }^{73}$ Pero los cuestionamientos al PCE no cesaron allí. A pesar de haber sido expulsada y cuestionada, Martínez sostuvo, en cartas privadas intercambiadas con su hijo,

69. Egas, "La lucha de la mujer...", 22.

70. Ibíd. Énfasis del original.

71. “Adiestramiento de mujeres", Nuestra Palabra, n. ${ }^{\circ} 4$ (junio 1963): 39. Énfasis en el original.

72. "Estatuto", Quito, 1 de abril de 1966, AM-M, carpeta URME.

73. "El Partido Comunista del Ecuador y nuestro Secretario General siempre mantuvieron en alto las banderas revolucionarias antiimperialistas", El Pueblo, Guayaquil, 13 de enero de 1968: 2; “El parto de los Montes”, El Pueblo, Guayaquil, 20 de enero de 1968: 2. 
que Pedro Saad era un "gran caimán tropical que duerme sobre el caudaloso Guayas", quien debido a la dedicatoria que el Boletín Internacional de la Paz publicó sobre URME y Nuestra Palabra", ${ }^{74}$ fomentó las medidas disciplinarias a sus militantes después del acto del 8 de marzo de 1963.

Otra lectura que nos suscita la correspondencia intercambiada entre Nela y Leonardo Paredes Martínez es la disputa que surgió en el seno del PCE debido al reconocimiento de URME como una organización afiliada a la FDIM. La reflexión sobre el "chantaje internacional" desplegado por el Partido contra las plataformas autónomas de mujeres devela otro punto de enfrentamiento. Con el afán de que no se reconozcan a otras organizaciones, y de proyectar una imagen unitaria frente a las plataformas internacionales, el PCE asumió la batuta de las organizaciones ecuatorianas de mujeres como propias. Sobre el malestar generado debido a la captación de la representación de las organizaciones femeninas, Martínez menciona que:

El chantaje internacional se ha convertido en norma permanente. Lo que se quiere es impedir que nuestras organizaciones sean consideradas afuera, ya que adentro no lo pueden obtener por más calumnias que lancen. Pero afuera es distinto, ellos manejan las relaciones internacionales. Así, en vísperas del Congreso de Moscú, se lanza la ofensiva para permitir que el turismo continúe y que no se esclarezcan las posiciones. ${ }^{75}$

La animadversión producida en el PCE debido a la autonomía de las organizaciones femeninas y su reconocimiento internacional creó temores internos que produjeron advertencias y separaciones de miembros ante el más mínimo indicio. En otras palabras, la organización femenina fue vista como una amenaza a la estructura interna, que, de cierto modo, fue incómoda para un partido jerárquico y masculino que valoraba la lealtad y la disciplina como rasgos dignos del "deber ser" comunista; es así que las retóricas cuestionadoras de ese tipo de dinámica: los debates sobre la igualdad que interpelaron al patriarcado, al tutelaje masculino, y el fomento de una agencia política en pos de reivindicar demandas para el movimiento de mujeres, no encajaban ni en los requerimientos ni en los valores de disciplina y obediencia que el PCE abanderaba. Por ello, ante la emergencia de una militancia disidente el partido estableció, en 1967, el control absoluto sobre el plan de trabajo con las mujeres, con la intención de evitar la propagación de "ideologías extrañas al proletariado", consideradas fraccionalistas.

74. Carta enviada por Nela Martínez a Leonardo Paredes...

75. Ibíd. 
La expresión del malestar ante los proyectos del PCE y la latente conflictividad con URME conllevó que algunas mujeres se plantearan la posibilidad de la autonomía como una alternativa para solventar problemas referentes a su diferencia sexual y los roles "estereotipados" que el partido proyectó sobre la militancia femenina. Ante ello, se perfiló un frente amplio de trabajo con comunistas, socialistas revolucionarias, y mujeres sin vinculación partidistas que "estén convencidas de que tienen que dar su aporte para acelerar el proceso revolucionario y hacer la revolución". ${ }^{76}$

La Unión Revolucionaria de Mujeres del Ecuador (URME) fue un frente de mujeres de izquierda que militó entre 1962 y 1966. Propugnaron por el trabajo colaborativo con otras organizaciones femeninas, como el Comité de Unidad por la Paz y la Soberanía, y la Unión Democrática de Mujeres del Ecuador. La organización se consideró a sí misma como "nueva, colectiva, sin jerarquías", sin una presidenta formal, constituida en comisiones en las cuales toda mujer podría encontrar un lugar de militancia sin ser discriminada por pertenecer a otros espacios políticos. ${ }^{77}$ Asimismo, sus miembros aclararon que URME no era "una organización de pupilas o esposas de políticos", sino compuesta por mujeres que "lo hacemos voluntaria y conscientemente, asociándonos para unir nuestras fuerzas frente a una sociedad injusta", ratificando, de ese modo, la necesidad de organización femenina y de lucha autónoma. ${ }^{78}$

Los lineamientos políticos de la organización se centraron en "la liberación efectiva de la mujer ecuatoriana que le permita ejercer sus derechos como ciudadanas, sin restricciones ni limitaciones; la independencia real del Ecuador, en ejercicio pleno de su soberanía; la soberanía popular como expresión política, social y económica de un pueblo cuyos derechos han sido escamoteados o traicionados sistemáticamente".${ }^{79}$ Estos planteamientos respondieron a una agenda pensada e imbricada en sus experiencias organizativas previas. No hay que perder de vista que, además de haber sido mujeres de partido, muchas de ellas militaban en plataformas femeninas desde los años treinta. ${ }^{80}$

Ahora bien, el énfasis en la autonomía y la apuesta organizativa sin jerarquías nos permite afirmar que estas propuestas otorgaron a las mujeres márgenes de acción independientes de las consignas partidistas; no obstante, eso

76. Ibíd.

77. Diana Arcentales [Nela Martínez], "Presencia y acción de las organizaciones de mujeres", Nuestra Palabra, n. ${ }^{\circ} 1$ (enero 1963): 12, 32.

78. "Estatuto".

79. Ibíd.

80. Vega, "Apuntes para una crítica feminista...", 149, 156; Terán Najas, "Historias de mujeres..."; Tatiana Salazar Cortez, "La experiencia de la Unión Revolucionaria de Mujeres del Ecuador (URME), 1962-1966" (tesis de maestría, Universidad Andina Simón Bolívar, Sede Ecuador, 2017), 18-35. 
no quiere decir que se alejaron totalmente de su matriz ideológica marxista, como lo sugiere Terán. ${ }^{81}$ Es más, URME se configuró como un espacio que le disputó, a la voz masculina del partido, acceso y legitimación en el escenario público y político. No pocos fueron los mecanismos a los que acudieron para transgredir el dominio masculino y jerárquico de la militancia política de izquierda; como bien lo señalamos, la crítica a la jerarquía se conjugó con la disputa de espacios de reconocimiento, como vimos con la FDIM, por ejemplo. También la revista Nuestra Palabra se configuró como un espacio clave para problematizar, desde la experiencia de su diferencia sexual, temáticas que el partido no consideraba -la vinculación al movimiento femenino internacional, la exaltación de la igualdad a través de figura de las guerrilleras cubanas, el analfabetismo infantil, la incorporación laboral de las mujeres profesionales, la igualdad de salarios, etc.- Además de constituirse como una revista de mujeres que buscaba no solo ser leída por ellas, debatieron sobre la reforma agraria, la posibilidad de un golpe de Estado al presidente Carlos Julio Arosemena, la revolución cubana, Fidel Castro, la guerra de Vietnam, antiimperialismo, antiyanquismo, anticapitalismo; planteamientos políticos e ideológicos que se configuraron como los debates contemporáneos de la izquierda sesentera. ${ }^{82}$ No obstante, este marco discursivo estuvo marcado por el sesgo crítico proveniente de la voz oficial del varón de izquierda. URME rechazó de plano al feminismo, considerándolo como reformista, burgués y ajeno al proletariado, acepción establecida por sus pares comunistas. ${ }^{83}$ Este distanciamiento con el movimiento feminista internacional le permitió legitimar a la organización en el espacio político en disputa: el escenario político de la izquierda partidista ecuatoriana.

Sin embargo, la apuesta autónoma trajo consigo posicionamientos disidentes. El hecho de que se consideren sujetos-agentes capaces de incidir en los procesos históricos les llevó a configurarse como un "instrumento de liberación" de las mujeres. Los planteamientos de URME enfatizaron en la necesidad de ser una organización capaz de solventar las contradicciones que estas miraban ante el sometimiento de las problemáticas femeninas a la lógica imperante de la dominación masculina del PCE; 84 es decir, ante "las jerarquías inútiles que revelan la existencia de una burocracia estéril", mencionaron:

81. Terán Najas, "Historias de mujeres...", 9.

82. URME publicó cuatro números de la revista Nuestra Palabra entre enero y junio de 1963. Un quinto número fue detenido en la imprenta debido al advenimiento del golpe dictatorial de julio de 1963.

83. Arcentales, "Presencia y acción...", 12, 32.

84. Pierre Bourdieu, La dominación masculina (Barcelona: Anagrama, 1998), 105-107; Pierre Bourdieu y Loïc J.D. Wacquant, "La violencia simbólica", en Respuestas por una antropología reflexiva (Ciudad de México: Grijalbo, 1995), 122. Bourdieu señala que "para 
Nosotras las mujeres, hemos sido, somos ahora mismo, objeto de discriminación. Parece increíble, pero hay "líderes" llamados revolucionarios que aceptan la participación de las mujeres en acciones colectivas, en una huelga, en una protesta, pero siempre a condición de que sirva, de que cumpla las órdenes, de que obedezca. Revolucionarios en la periferia, conservadores en la médula, le niega a la mujer PENSAMIENTO Y CAPACIDAD, para discernir, para tener opinión. Contra este espíritu cavernario hemos reaccionado. ${ }^{85}$

La experiencia generada por la diferencia sexual que fue articulada por las mujeres de izquierda en espacios de militancia partidista y organizativa, estuvo atravesada por las lecturas dominantes provenientes de la normatividad masculina. ${ }^{86}$ Por ello, el PCE proyectó estereotipos tradicionales sobre el componente femenino en sus filas. Adicionalmente, si bien algunas militantes fueron críticas a estos lineamientos, otras no. El compromiso revolucionario llevó a que mujeres comunistas se comprometan, independientemente de su diferencia sexual, con la lucha revolucionaria llevada a cabo por el proletariado en contra del capitalismo. Este factor llevó a que mujeres como Alba Calderón representen la voz oficial del partido por varias ocasiones en encuentros internacionales: el Congreso Mundial de Mujeres llevado a cabo en Copenhague en 1953 o el Congreso de Mujeres organizado por la FDIM en $1963 .{ }^{87}$ Los postulados de Calderón, si bien reflejan el reconocimiento de la necesidad de la organización femenina abanderada por el partido y el compromiso de cumplir con el "modelo de mujer latinoamericana" de la revolucionaria Cuba; la problemática de la discriminación hacia la mujer, y las causas femeninas vinculadas con la maternidad y el cuidado de la infancia también fueron su foco de preocupación. ${ }^{88}$ Es decir, para el PCE y sus militantes, la lectura sobre "lo femenino" reafirmó el estereotipo de mujer maternizada, asociada al cuidado del hogar y subordinada al proyecto partidista. ${ }^{89}$

ilustrar la lógica de la dominación masculina que al parecer constituye la forma más paradigmática de la violencia simbólica [donde la dominación sexual] es una institución inscrita por milenios en la objetividad de las estructuras sociales y en la subjetividad de las estructuras mentales", naturaliza la dominación masculina en el orden establecido como la reproducción de un orden social androcéntrico que emplea a instituciones como la familia, la Iglesia, el Estado, y la escuela para ejercer violencia simbólica sobre los agentes dominados. El partido político también es una estructura que naturaliza dicha exclusión de las actividades de dirigencia y decisión.

85. Arcentales, "Presencia y acción...", 12, 32. Énfasis del original.

86. Casola, "Con 'm' de 'mamá'...", 1-9.

87. "Las tareas de las mujeres...", 4; "Entrevista a Alba Calderón”, El Pueblo, 3 de septiembre de 1960: 5.

88. "Sobre Cuba, ejemplo de América. Nos habla Alba Calderón", El Pueblo, 16 de septiembre de 1961: 6; "Saludamos en el día...", 5.

89. Casola, "Con 'm' de 'mamá'...", 9. 
El sometimiento a los lineamientos partidistas ocasionó que, en la advertencia de Silvia Vega, las demandas de la vida cotidiana se contrapongan a la política. Si bien las reflexiones de las militantes de la década de los sesenta no evidencian las disputas entre la división sexual de las actividades y la conflictividad sobre la maternidad o las dinámicas sexuales internas, las militantes de los años posteriores se hicieron eco de ese malestar. ${ }^{90}$ El ejemplo de la militancia de los años setenta permite proyectar sobre los años anteriores las mismas limitaciones y conflictos. Tal como lo señala Tamara Vidaurrázaga, para el caso argentino, por ejemplo, el partido político tendió a ser un espacio masculino y masculinizante en el cual las demandas de igualdad de las mujeres tuvieron que acoplarse a la moral y valores masculinos. ${ }^{91}$ En casos particulares su cuestionamiento hacia la diferencia sexual encontró grandes diques que fueron sorteados con la desafiliación y las apuestas autónomas, acciones que fueron replicadas por militantes comunistas en otros países. ${ }^{92}$

Finalmente, en este amplio recorrido se inscribió la experiencia militante de las mujeres de izquierda como un fenómeno personal imbricado en un entramado político, cultural y social dominado por la figura masculina; ${ }^{93}$ es decir, la configuración de la militancia femenina, si bien ratificó la apropiación de la diferencia sexual de las mujeres, configuró, a su vez, actividades en espacios políticos que se nutrieron de sus experiencias previas, sean partidistas o autónomas, otorgándoles un margen de acción propio y generado desde sus problemáticas particulares.

\section{Conclusiones}

La mirada institucional del PCE sobre la militancia femenina corresponde a la lectura masculina presente en la sociedad ecuatoriana patriarcal de la época y en la dinámica partidista y jerárquica de la organización. A lo largo de este texto apreciamos cómo "el problema de las mujeres" fue valorado y articulado desde la lectura de los varones dirigentes del PCE; por ello, en

90. Vega, "Apuntes para una crítica feminista...", 149, 156.

91. Tamara Vidaurrázaga Aránguiz, "Subjetividades sexo genérica en mujeres militantes de organizaciones político-militares de izquierda en el Cono Sur", La Ventana, n. ${ }^{\circ}$ 41 (2015): 7-34.

92. Natura Olivé, Mujeres comunistas en México en los años treinta (Ciudad de México: Quinto Sol, s. r.), 8, 23; Ana Lau Jaivén, "La Unión Nacional de Mujeres Mexicanas entre el comunismo y el feminismo: Una difícil relación”, La ventana, n. ${ }^{\circ} 40$ (2014): 165-185; Catalina Trebisacce, "Encuentros y desencuentros entre la militancia de izquierda y el feminismo en la Argentina", Estudios Feministas 21, n. 2 (mayo-agosto 2013): 439-462.

93. Joan Scott, "Experiencia", La ventana, n. ${ }^{\circ} 13$ (2001): 68-73. 
algunos casos, mujeres críticas al proyecto partidista miraron en la organización autónoma la posibilidad de desarrollar mecanismos que les permitió plasmar sus demandas e intereses, disputar reconocimiento y legitimidad en el escenario político de la izquierda partidista ecuatoriana, espacio tradicionalmente dominado por la figura masculina.

La década de los sesenta minó la organización partidista del PCE debido a la amenaza fraccionalista surgida por el ejemplo de la guerra de guerrillas cubana y la crítica proveniente de los grupos disidentes surgidos en sus filas. Si bien el PCE trató de frenar dicha arremetida mediante sanciones y normativas internas, sus filas fueron notoriamente mermadas. A este contexto se sumó el proceso electoral de 1968; es así cómo las mujeres pasaron a jugar un papel clave para el robustecimiento del partido y la lucha revolucionaria planificada de masas. Sin embargo, el intento de reclutar a mujeres estuvo enmarcado en la lógica masculina, jerárquica y vertical de la estructura partidista. Ante este panorama de dominio masculino naturalizado -siguiendo los aportes del Pierre Bourdieu-, miramos cómo los planteamientos clasistas sobre la revolución y la lucha de clases subordinaron las demandas de liberación de la mujer.

Ante este horizonte de militancia femenina y de un evidente proceso de conciencia de su diferencia sexual, algunas mujeres vinculadas a la organización partidista miraron en el "deber ser" comunista un espacio hostil para sus proyectos; por ello apostaron por la autonomía. Desde el nuevo proyecto continuaron con las demandas izquierdistas, propias de sus anteriores experiencias, pero articuladas a su lectura sobre la lucha por la "liberación de la mujer". A pesar de que la matriz marxista se proyectó sobre sus postulados, la búsqueda de legitimación de las mujeres como pertenecientes a la esfera política de la izquierda llevó a que acojan para sí el sistema de valores masculinos de la lógica partidista. De este modo, generaron un margen de agencia que posibilitó problematizar la lucha por la liberación de la mujer ecuatoriana, sin embargo esta estuvo atravesada por sus experiencias anteriores en el espacio político. Factor que explica la reticencia de asumir postulados considerados como "reformistas o burgueses".

Finalmente, si bien la apertura de militancia para las mujeres en la izquierda constituyó una ruptura con el estereotipo de mujer -articulada al espacio privado y doméstico-, la estructura partidista reforzó, mediante su lógica jerárquica, la dominación masculina de la dirigencia, no solo ante la desavenencia de los grupos fraccionalistas, sino que además reforzaron el lugar subordinado de la mujer a una organización notoriamente masculina, proyectando sobre la militancia femenina, apreciaciones estereotipadas en cuanto al ideal de mujer de izquierda; un ejemplo de ello fue el rechazo al feminismo. Entonces, conviene cuestionarnos, cuál fue la lectura que la izquierda hizo sobre el feminismo, si acaso surgieron debates críticos sobre 
sus aportes, o predominó el sesgo liberal, reformista y burgués sobre el movimiento internacional. Sin duda, es un tema que tiene diversas entradas y podría ser una continuación del trabajo que ahora presentamos.

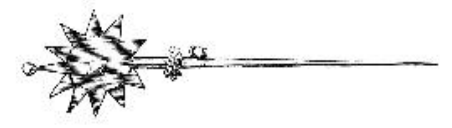

\section{FUENTES Y BIBLIOGRAFÍA}

Archivo Martínez-Mériguet (AM-M)

Carpeta URME.

Carpeta Leyes, estatutos, reglamentos.

Correspondencia, 1960-1966.

Carpeta Periódicos 40/50/60.

Carpeta Escritos políticos.

Carpeta Pronunciamientos políticos varios, n. ${ }^{\circ} 2$.

Fondo Luisa Gómez de la Torre.

\section{FUENTES PRIMARIAS}

El Pueblo, 1954-1970.

Nuestra Palabra, 1963.

Mañana, 1962-1967.

\section{BIBLIOGRAFÍA}

Aguirre, Manuel Agustín. "Introducción". En Carlos Marx, en homenaje al centenario de su muerte, 3-62. Cuenca: Universidad de Cuenca / IDIS, 1983.

Bonilla, Adrián. En busca del pueblo perdido. Diferenciación y discurso de la izquierda marxista en los sesenta. Quito: FLACSO / Abya-Yala, 1991.

Bourdieu, Pierre. La dominación masculina. Barcelona: Anagrama, 1998. y Loïc J.D. Wacquant. "La violencia simbólica”. En Respuestas por una Antropología reflexiva, 101-127. Ciudad de México: Grijalbo, 1995.

Cabrera Hanna, Santiago, editor. La Gloriosa, ¿Revolución que no fue? Quito: Universidad Andina Simón Bolívar, Sede Ecuador / Corporación Editora Nacional, 2016.

Casola, Natalia. “Con 'm' de 'mamá': Las militantes comunistas y la Unión de Mujeres Argentinas durante la segunda mitad del siglo XX". Amnis, n. ${ }^{\circ} 13$ (2014): $1-9$.

Cueva, Agustín. "El marxismo latinoamericano: Historia y problemas actuales". En Entre la ira y la esperanza y otros ensayos de crítica latinoamericana, 177-200. Buenos Aires: CLACSO, 2008 [1987]. 
Estatutos de Asociación Femenina Universitaria del Ecuador, filial de Quito. Quito: Imprenta de la Universidad, 1952.

Goetschel, Ana María. "Estudio introductorio". En Orígenes del feminismo en el Ecuador. Antología, 13-56. Quito: CONAMU / FLACSO / UNIFEM, 2006.

Hobsbawm, Eric. Historia del siglo XX. Barcelona: Crítica, 2010 [1994].

Ibarra, Hernán. "Los idearios de la izquierda comunista ecuatoriana (1928-1931)". En El pensamiento de la izquierda comunista (1928-1961), 11-64. Quito: Ministerio de Coordinación de la Política y Gobiernos Autónomos Descentralizados, 2013.

. "En torno a los fantasmas de la izquierda radical ecuatoriana del setenta". En Memorias del seminario internacional: El legado intelectual y político de Fernando Velasco Abad, coordinado por Santiago Ortiz Crespo y Soledad Álvarez Velasco, 163-176. Quito: FLACSO, 2014.

Jaivén, Ana Lau. "La Unión Nacional de Mujeres Mexicanas entre el comunismo y el feminismo: Una difícil relación". La ventana, n. ${ }^{\circ} 40$ (2014): 165-185.

Martínez Espinosa, Nela, y Ximena Costales. Yo siempre he sido Nela Martínez: Una autobiografía hablada. Quito: CONAMU / UNIFEM, 2006.

Olivé, Natura. Mujeres comunistas en México en los años treinta. Ciudad de México: Quinto Sol, s. r.

Pipitone, Ugo. La esperanza y el delirio. Una historia de la Izquierda en América Latina. Bogotá: Penguin Random House, 2015.

Programa del Partido Comunista del Ecuador. Guayaquil, 4 de agosto de 1968.

Rodas Chaves, Germán. "La izquierda ecuatoriana en la década de 1960 y la influencia de la Revolución Cubana". En La izquierda ecuatoriana. Aproximación histórica, 63-93. Quito: Abya-Yala / La Tierra, 2004.

Salazar Cortez, Tatiana. “La experiencia de la Unión Revolucionaria de Mujeres del Ecuador (URME), 1962-1966". Tesis de maestría. Universidad Andina Simón Bolívar, Sede Ecuador, 2017.

Scott, Joan. "Releer la historia del feminismo". En Las mujeres y los derechos del hombre. Feminismo y sufragio en Francia, 1789-1944, 17-37. Buenos Aires: Siglo XXI, 2012. . "Experiencia". La ventana, n. 13 (2001): 68-73.

. "Algunas reflexiones sobre género y política". En Género e historia, 247-255. Ciudad de México: Fondo de Cultura Económica / Universidad Autónoma de la Ciudad de México, 2008.

Terán Najas, Rosemarie. “Historias de mujeres: El 'ser colectivo' de Nela Martínez Espinosa". En Nela Martínez, Insumisas. Textos sobre las mujeres, 7-25. Quito: Ministerio Coordinador de Patrimonio, 2012.

Tinajero, Fernando. "Rupturas, desencantos y esperanzas (Cultura y sociedad en el Ecuador: 1960-1985)". Revista Iberoamericana, n. ${ }^{\circ} 144-145$ (julio 1988): 791-810.

Trebisacce, Catalina. "Encuentros y desencuentros entre la militancia de izquierda y el feminismo en la Argentina". Estudios Feministas 21, n. ${ }^{\circ} 2$ (mayo-agosto 2013): 439-462.

Vega, Silvia. "Apuntes para una crítica feminista de la izquierda de los setenta". En Memorias del seminario internacional: El legado intelectual y politico de Fernando Velasco Abad, coordinado por Santiago Ortiz Crespo y Soledad Álvarez Velasco, 145-162. Quito: FLACSO, 2014. 
. La Gloriosa. De la revolución de 28 de mayo de 1944 a la contrarrevolución velasquista. Quito: El Conejo, 1987.

Vidaurrázaga Aránguiz, Tamara. "Subjetividades sexo genérica en mujeres militantes de organizaciones político-militares de izquierda en el Cono Sur". La Ventana, n. ${ }^{\circ} 41$ (2015): 7-34. 


\section{Debates}





\title{
La política plebeya en las parroquias rurales de Cuenca, 1995-2005*
}

\author{
Peasant politics in the rural parishes \\ of Cuenca, 1995-2005
}

\section{Mónica Mancero Acosta}

Universidad Central del Ecuador mpmancero@uce.edu.ec

DOI: http:/ / dx.doi.org/10.29078/rp.v0i46.650

Fecha de presentación: 26 de abril de 2017 Fecha de aceptación: 22 de septiembre de 2017

Artículo de investigación

* Este trabajo contó, parcialmente, con el apoyo del Instituto Francés de Estudios Andinos, IFEA, a través de un concurso regional para fondos de investigación. Además, se hizo acreedor a una beca de ayuda para proyectos de investigación de la Universidad Andina Simón Bolívar, para exestudiantes de maestría. Agradezco a ambas instituciones por su apoyo. 


\title{
RESUMEN
}

Este artículo examina la irrupción de los líderes rurales de las parroquias del cantón Cuenca, denominados "cholos políticos" en la arena de la política plebeya. Los testimonios de los líderes parroquiales rurales son el material fundamental de la investigación. En primer

lugar, el artículo establece un estado de la cuestión en la literatura sobre construcciones raciales y política; luego se analiza lo que se ha denominado como proceso de conformación de "ciudadanía plebeya".

Con este propósito se estudian las demandas de los líderes parroquiales del cantón Cuenca, un espacio territorial marcado por procesos de racionalización y de discriminación social por su origen campesino.

Palabras clave: historia de América Latina, historia social, historia política, Ecuador, Cuenca, siglo XX, siglo XXI, comunidades indígenas, ruralidad.

\begin{abstract}
This article examines the emergence of rural leaders in the parishes of the canton of Cuenca, called "cholos políticos" [indigenous peasant

politicians] in the context of peasant politics. The testimonies of rural parish leaders are the key sources for the research. The article first provides a baseline situation of the subject in the literature on racial constructs and politics; afterwards, it reviews what has been called the process of establishing a "peasant citizenry". To this end, it examines the demands made by parish leaders of the canton of Cuenca, a territory marked by rationalization and social discrimination because of its peasant origins.
\end{abstract}

Keywords: History of Latin America, social history, political history, Ecuador, Cuenca, twentieth century, twenty-first century, indigenous communities, rurality.

Mónica Mancero Acosta

Doctora en Ciencias Sociales con especialización en Estudios Políticos por FLACSO. Ha sido profesora de la Universidad de Cuenca, Universidad San Francisco de Quito, Instituto de Altos Estudios Nacionales y profesora invitada en varias universidades de México. Actualmente es profesora de Teoría Política en la Universidad Central del Ecuador. Tiene varias publicaciones sobre estudios políticos contemporáneos y feminismos. 


\section{INTRODUCCIÓN}

En la zona sur del austro ecuatoriano, específicamente en la provincia del Azuay a la cual pertenece la ciudad de Cuenca, persisten discriminaciones raciales. Los habitantes de la ruralidad generalmente son calificados de "cholos" y "cholas" por los blanco-mestizos asentados en el área urbana, quienes mantuvieron una dominación política y de clase en la región durante un período prolongado. La política tradicionalmente estaba a cargo de las élites "nobles" blanco-mestizas, y los "cholos" estaban apartados de esta esfera. A mediados de la década de los noventa, se constata una emergencia de actores políticos subalternos cholos. En el período 1995-2005, la ciudad y sus parroquias rurales circundantes son dirigidas por Fernando Cordero, representante del movimiento político Nueva Ciudad, en calidad de alcalde. El carácter de este proyecto desata la participación política de los líderes parroquiales. Este proceso conlleva tensiones irresueltas tanto por el persistente racismo, como por la relativa marginación de la zona rural.

El presente artículo pretende problematizar este proceso de irrupción de actores a quienes denomino "cholos políticos", y entender el alcance que tuvo en la política plebeya y aún en la institucional. Específicamente, en este trabajo rastreo una pregunta de investigación relativa a tratar de interpretar qué significaciones tiene, en las representaciones simbólicas y en el sistema político, el despliegue de una política plebeya que emergió en los espacios rurales de la "noble" ciudad de Cuenca.

La esfera política rural ha sido escasamente estudiada en el país. Se ha privilegiado la investigación de lo rural desde una perspectiva sociológica relacionada con el territorio, la producción y la estructura social del campesinado. La dinámica política no ha sido objeto de preocupación, quizás bajo el entendido de que se trata de la "pequeña política". ${ }^{1}$

En este trabajo he acudido a los líderes de las parroquias rurales para tratar de capturar sus percepciones y representaciones: este constituye el material fundamental de la investigación. Tres de los cuatro líderes parroquiales, a quienes realicé entrevistas en profundidad, fueron dirigentes parroquiales durante el período en que se focaliza el estudio y las entrevistas estaban dirigidas a valorar este proceso, mientras que una última entrevista se hizo con un líder reciente, con la finalidad de cotejar la actualidad de la información. Además, he analizado la prensa regional, así como información secundaria

1. Gilles Pécout, "Le local et le national, le centre et la périphérie", Le Mouvement Social 187 (1999): 3-9, http:/ / www.jstor.org/stable/3779094. 
de carácter estadístico, que se focaliza en el período de estudio, pero cuyos procesos frecuentemente se extienden hasta la actualidad. Parto por establecer un estado de la cuestión en la literatura sobre construcciones raciales y política; luego examino lo que he denominado el proceso de conformación de ciudadanía plebeya. Para ello, analizo las demandas de los líderes parroquiales, así como sus prácticas y discursos.

Cuando hablo de raza asumo el sentido que le da Peter Wade como un juego de ideas acerca de los humanos, que pueden tener consecuencias como discriminación o violencia racial. ${ }^{2}$ Llamo "cholos políticos" a los líderes parroquiales rurales como un gesto por posicionar a estos actores subalternos dentro de una matriz de dominación con fuertes componentes de racialización, que se ha ido transformando, aunque no totalmente, en la ciudad y región. Los actores políticos estudiados no se autoidentifican como cholos sino más bien como campesinos. La categoría "cholo" tiene un sentido complejo en la región, de discriminación de unos sectores sociales sobre otros, pero ha sido usada en una tradición académica crítica con el objetivo de recalcar relaciones sociales que están permeadas de discriminaciones raciales.

Asimismo, conceptualizo como "política plebeya" a las representaciones, prácticas y discursos de estos actores subalternos. Es una política diferenciada de la práctica institucional formal de la urbe. Se caracteriza por ser una política, que, como ellos mismos lo han dicho, se hace "con los de aba$\mathrm{jo}^{\prime \prime}$, es colectiva y requiere un sentido de pertenencia, refuncionaliza prácticas tradicionales como la minga y las asambleas, se basa en el bien común de la gente rural y se opone a tratos discriminatorios desde los habitantes urbanos blanco-mestizos dominantes.

Mi argumento, en este trabajo, es que la política plebeya, desplegada por los cholos políticos, fue una oportunidad histórica en la región para potenciar una democracia radical. Esta dinámica generó algunos avances; sin embargo, no fue profundizada, pues observamos que constantemente ha sido revertida propiciando nuevas inequidades y la persistencia de imaginarios racializados que se reproducen en la esfera política.

\section{INTERPRETACIONES SOBRE LO RACIAL Y LA POLÍtica eN AmÉrica LATINA}

Diversos autores han explorado la relación entre raza y participación política en América Latina. La raza es analizada en términos culturales y no

2. Peter Wade, "Race in Latin America". En A Companion to Latin American Anthropology, ed. por Deborah Poole (Malden / Oxford: Blackwell Publishing, 2008), 177-192. 
biológicos; lo más importante, al explicar la cultura política en términos raciales, son los rasgos comunes que un grupo étnico comparte y cómo se contrapone a otros grupos, dando origen a desigualdades o discriminaciones.

Wade concibe la raza como un conjunto de ideas sobre la similitud y diferencia de los seres humanos. ${ }^{3}$ No es un concepto estático, sino que responde a los valores sociales de cada época. Wade concluye que la discriminación no es institucionalizada ni sistemática, sino individualista, silenciosa, enmascarada. Sostiene que grupos indígenas sufren discriminación, sobre todo en contextos urbanos, porque la estructura social colonial no se ha eliminado del todo en la región.

En esta misma tesitura, Carmen Romero nos previene acerca de que la afirmación de la inexistencia de razas parece dejarnos desarmados para enfrentar un racismo que se difumina en términos de conflictos culturales o de xenofobia. Si la raza es una invención política, nos dice la autora, sin duda tiene numerosos y dramáticos efectos de realidad. En este contexto, Romero se pregunta: ¿es posible eliminar los efectos del racismo eliminando el término raza? ${ }^{4}$

La noción de raza en Ecuador ha estado indefectiblemente unida al debate sobre la población indígena. El trabajo de Mercedes Prieto hace un recorrido por esta noción que se introdujo en las élites ecuatorianas durante la primera mitad del siglo XX, la cual fue utilizada para construir la imagen de los indígenas como "ciudadanos inferiores" que suscitaban temor entre las élites. ${ }^{5}$ La autora concluye que "la raza fue usada como un concepto flexible que permitió argumentar diferentes grados de inferioridad/superioridad, al tiempo que promovía sentimientos de temor entre las élites". ${ }^{6}$

En Ecuador, la literatura que aborda la participación política étnica se enfoca en el movimiento indígena. Así, Sánchez Parga, de forma penetrante, logra establecer una lógica dual que primó en el accionar político del movimiento. La opción étnica que privilegió el espacio político de la comunidad, parroquia, cantón y entornos rurales; mientras que la opción clasista o interétnica enfatizó en el espacio político de dirigencia de federaciones locales y regionales. El partido Pachakutik expresa la segunda orientación, mientras que los movimientos y organización provinciales mantendrán la primera. ${ }^{7}$

3. Ibíd., 177.

4. Carmen Romero, "Los desplazamientos de la raza, de una invención política y la materialidad de sus efectos", Política y Sociedad, n. ${ }^{\circ} 1$ (2003): 113.

5. Mercedes Prieto, Liberalismo y temor. Imaginando los sujetos indígenas en el Ecuador postcolonial 1895-1950 (Quito: FLACSO Ecuador / Abya-Yala, 2004), 79.

6. Ibíd., 72.

7. José Sánchez Parga, “Los indígenas ante los poderes y gobiernos locales”. En El Movimiento indígena ecuatoriano. La larga ruta de la comunidad al partido (Quito: Centro Andino de Acción Popular, 2007), 111. 
En una tesitura similar, Becker señala que el debate era si los indígenas debían organizarse como una etnia o en alianza con otros sectores populares, ya que los partidos políticos ignoraban las cuestiones indígenas. ${ }^{8}$

Sánchez Parga analiza el proceso de irrupción de las parroquias y de debilitamiento de las comunas, desde una perspectiva compleja, donde no hay un simple juego de suma cero. ${ }^{9}$ La creación de las Juntas Parroquiales en el 2000 constituyó un dispositivo que amplió la participación política indígena, pero también propició su integración al Estado nacional. A pesar de que las juntas absorbieron el poder político de los cabildos y significaron una ampliación política del poder estatal, se convirtieron en un espacio de conquista política por parte de las poblaciones comuneras, ya que supuso neutralizar la presencia política del Estado con el teniente político y disputar a las minorías mestizas la hegemonía del centro parroquial. A la vez, las Juntas Parroquiales han implicado un debilitamiento de las comunidades y sus autoridades y se ha llevado a las parroquias las divisiones del conflicto político electoral.

El racismo ha constituido una arista en los análisis políticos de las organizaciones y pobladores indígenas y minorías afros. Para Becker el racismo constituyó un fuerte impedimento para el triunfo de la candidatura nacional indígena de Pachakutik en 1996, ya que había sido interiorizado en las comunidades indígenas que mostraban más confianza en candidatos mestizos que indígenas. ${ }^{10}$ De la Torre, por su parte, argumenta que el racismo en las interacciones cotidianas entre afroecuatorianos y blanco mestizos, se dan por doble vía, de blancos y mestizos hacia indígenas y negros y, viceversa. ${ }^{11}$ Específicamente, el racismo por parte de los indios se basa en la búsqueda de lo que De la Torre denomina una "revancha étnica o racial". Así, mientras para Becker el racismo en los indígenas sería algo interiorizado en ellos, probablemente debido al legado colonialista, De la Torre ha enfatizado en un racismo de resarcimiento, que llevaría a una suerte de repliegue étnico.

Un debate central acerca de la participación política de los indígenas han sido los temas económicos y de clase, frente al tema cultural y étnico. Alguna literatura resiente la ausencia de la perspectiva de clase, y plantea que ha habido un florecimiento de las demandas étnicas gracias a la incursión de las ONG y una emergencia del paradigma neoliberal, lo que ha llevado a

8. Marc Becker, "Movimiento Unidad Plurinacional Pachakutik”. En ¡Pachakutik!: Movimientos indígenas, proyectos políticos y disputas electorales en el Ecuador (Quito: FLACSO Ecuador / Abya-Yala, 2015), 56.

9. Sánchez Parga, "Los indígenas ante los poderes...", 114-115.

10. Becker, "Movimiento Unidad Plurinacional...", 61-62.

11. Carlos de la Torre Espinosa, "Introducción", En Afroquiteños: ciudadanía y racismo (Quito: CAAP, 2002), 16. 
consolidar un neo-indigenismo etnófago. ${ }^{12}$ Para otros autores, el privilegio que se dio en la sociología ecuatoriana a la clase, llevó a desconocer lo étnico y la discriminación racial. ${ }^{13}$ En cualquier caso, se plantea que la etnicidad va sustituyendo a la clase, llegando a constituirse en factor de identidad y de movilización política. Esta etnización de lo político ha buscado redefinir el Estado hacia uno multiétnico o pluricultural. ${ }^{14}$

En contraposición, León Galarza argumenta que la identidad política y de protesta va más allá de una sustitución dicotómica de clase por etnia, ya que no se trata de identidades rígidas y delimitadas, sino de una relación de sentidos políticos entre alteridades. ${ }^{15}$ Alianzas interétnicas fueron el sustento de la formación de identidades locales, ya que aportaron herramientas lingüísticas para formar un discurso político de negociación con el Estado y con la sociedad mestiza dominante a finales del siglo XX. De la revisión de la literatura queda claro que ha habido una apuesta política del movimiento indígena, pues se ha llegado a hablar de que la finalidad del movimiento consistió en apoderarse del espacio rural en los ámbitos político e ideológico. ${ }^{16}$

Los cholos políticos, sujetos de mi investigación, no han tenido lazos sustanciales con las organizaciones del movimiento indígena, por ello no se puede hacer totalmente extensiva la interpretación de esta literatura. Sin embargo, es claro que ellos se inscriben en la revitalización de los espacios de lo parroquial con una dinámica de poder como la referenciada por Sánchez Parga. Pero también, en este caso, me parece válida una articulación entre lo identitario y lo clasista, en la tesitura que lo plantea León Galarza.

Investigaciones sobre política, realizadas desde una perspectiva institucionalista, han desdeñado consideraciones de racialización de los sujetos políticos. Silva sostiene, al igual que Wade, que ha existido continuidad his-

12. Víctor Bretón, "Desarrollo rural y etnicidad en las tierras altas de Ecuador". En Estado, etnicidad y movimientos sociales en América Latina. Ecuador en crisis, ed. por Víctor Bretón y Francisco García (Barcelona: Icaria, 2003), 218-219.

13. De la Torre Espinosa, "Introducción", 13.

14. Christian Büschges, "Políticas de identidad entre integración y autonomía: movimiento indígena, sociedad y Estado en Ecuador y Nepal desde una perspectiva comparativa y transnacional". En Los Andes en movimiento. Identidad y poder en el nuevo paisaje político, ed. por Pablo Ospina, Olaf Kaltmeier y Christian Büschges (Quito: Universidad Andina Simón Bolívar, Sede Ecuador / Universidad de Bielefed / Corporación Editora Nacional, 2009), 53-57.

15. Natalia Catalina León Galarza, “¿Identidades post-clasistas? La protesta indígena de fin de siglo". En Etnicidad y poder en los países andinos, ed. por Christian Büschges, Guillermo Bustos y Olaf Kaltmeier (Quito: Universidad Andina Simón Bolívar / Universidad de Bielefeld / Corporación Editora Nacional, 2007), 163.

16. Olaf Kaltmeier, "Estado, espacio y etnicidad: prácticas y representaciones espaciales en Cotopaxi entre la mímesis y la alteridad". En Los Andes en movimiento..., 197. 
tórica de un modelo de Estado jerárquico de origen colonial. Según Silva, “A la competencia por el poder político solo pueden acceder aquellos grupos que se ubican en el ápice de la pirámide social, los que concentran los recursos necesarios y suficientes para participar exitosamente en la contienda". ${ }^{17}$

Tenemos escasos análisis acerca de las significaciones del "cholaje" en el Ecuador. Una reflexión pertinente la encontramos en un estudio de Ibarra, quien destaca que el cholo en Ecuador tiene características derivadas tanto de su rol económico como cultural:

La imagen es la de un continuo que va de indio a mestizo mediante un proceso de aculturación. El cholo era el que se insertaba en los circuitos de comercialización de ganado y productos agrícolas, produciéndose un cambio étnico que acompañaba el ascenso económico. Sin embargo, el cholo por su función de intermediario en la circulación aparecerá después como el que tiene un papel primordial en forjar lazos y redes de compadrazgo con los indígenas. ${ }^{18}$

El debate sobre el mestizaje en el Ecuador ha acompañado la propia configuración del Estado nacional. De acuerdo con la interpretación de Almeida, el proyecto de mestizaje fue la ideología de la ecuatorianidad, según la cual son los troncos indios y negros los que debieron subsumirse al tronco blancomestizo, por ello imperó el blanqueamiento en búsqueda de la anhelada integración nacional. ${ }^{19}$ Sin embargo, actualmente la identidad blanco-mestiza estaría en fase de repliegue, mientras que la indígena, en fase de recomposición.

Desde otra perspectiva, Espinosa manifiesta que la contraposición entre indígenas y mestizos es artificiosa, puesto que los mestizos son realmente aquellos de ascendencia indígena quichua. El autor acusa a la Antropología de haber difundido estereotipos etnocentristas. ${ }^{20} \mathrm{En}$ mi percepción, los esquemas raciales persisten porque son útiles y resultan funcionales a dominaciones determinadas. De este modo, resulta pertinente diferenciar niveles, unos se corresponden con representaciones ideológicas -mestizaje, blanqueamiento- y otros con configuraciones de grupos humanos por el color de piel o procedencia.

En un trabajo previo, al estudiar las cholas cuencanas contrasté el proyecto racial del Cuzco con el de élites conservadoras cuencanas. ${ }^{21}$ Pude ad-

17. Erika Silva, Identidad nacional y poder (Quito: Abya-Yala, 2004), 73.

18. Hernán Ibarra, "La revaloración del cholo y la cholificación". En La otra cultura. Imaginarios, mestizaje y modernización (Quito: Marka / Abya-Yala, 1998), 17.

19. José Almeida, "Identidades en el Ecuador. Un balance Antropológico". En Ciudadania e identidad, comp. por Simón Pachano (Quito: FLACSO Ecuador, 2003).

20. Manuel Espinosa, Los mestizos ecuatorianos y las señas de identidad cultural (Quito: Tramasocial, 2000), 15.

21. Mónica Mancero Acosta, Nobles y cholos: Raza, género y clase en Cuenca 1995-2005 (Quito: FLACSO Ecuador, 2002). 
vertir que, mientras en el Cuzco fue un proyecto estratificado, populista y masculino, según ha estudiado De la Cadena, ${ }^{22}$ en Cuenca las élites fabricaban una imagen de la chola asociada al folklor, como fruto de un mestizaje clausurado. La economía moral de las cholas, según mi interpretación, es una estrategia desplegada para tratar de reducir las enormes distancias históricas que persisten, entre los "nobles" y los "cholos" en la región. ${ }^{23}$

Para Walsh existen luchas coloniales inconclusas, la identidad ecuatoriana ha sido construida a partir de la negación de lo indígena y negro, por parte de la sociedad mestiza. ${ }^{24}$ Pero el intento de blanquear la sociedad y utilizar el mestizaje como factor homogeneizador, no tuvo éxito. Así, vemos una línea común en los análisis de los autores presentados. Todos ellos coinciden en que las jerarquías raciales coloniales siguen presentes en Ecuador y Latinoamérica, e influencian en el escenario político.

En Perú, Marisol de la Cadena examina el concepto del mestizaje como un híbrido conceptual. ${ }^{25} \mathrm{Al}$ inicio, el mestizaje fue entendido como la mezcla entre dos "razas puras" y por tanto fue despreciado, pero luego se lo utilizó como método para tratar de civilizar el campo a través de la educación. Francois Bourricaud, también se enfoca en Perú y considera que el cholo tiene debilidades y vicios de ambas culturas. ${ }^{26}$ El mestizo, en cambio, se describe como traidor, inestable y ansioso. El cholo conserva la cultura tradicional, aun cuando va a las ciudades.

Guillermo Nugent, quien escribió su libro con el sugerente título El laberinto de la choledad en el contexto peruano, en un artículo reciente revisita su texto y plantea que no hay razas, puesto que líneas raciales no son capaces de delimitar campos o equilibrios en la balanza de poder en momentos de cohesión o de crisis. ${ }^{27}$ Plantea la figura de la "pigmentocracia" referida al distinto tono de piel. Mientras el racismo se expresa como segregación y separación, eso no ocurre en Latinoamérica, se trata más bien de subordinación, puesto que conviven en los mismos espacios.

22. Marisol de la Cadena, Indígenas mestizos: raza y cultura en el Cuzco (Lima: Instituto de Estudios Peruanos, 2004).

23. Mancero Acosta, Nobles y cholos: Raza...

24. Catherine Walsh, "Raza, mestizaje y poder: Las bases estructural-discursivas de la sociedad ecuatoriana". En Interculturalidad, Estado y sociedad: Luchas (de)coloniales de nuestra época, ed. por Catherine Walsh, 25-40 (Quito: Universidad Andina Simón Bolívar, Sede Ecuador / Abya-Yala, 2009).

25. Marisol de la Cadena, "The Racial Politics of Culture and Silent Racism in Peru". Documento presentado en la Conferencia Racism and Public Policy (Durban: United Nations Research Institute for Social Development, 2001).

26. François Bourricaud, “¿Cholificación?”. En El indio y el poder en el Perú, 183-198 (Lima: Moncloa / Campodónico, 1970).

27. Guillermo Nugent, "El laberinto de la choledad, años después", Quehacer, n. ${ }^{\circ} 170$ (2008): 7, https:/ / es.scribd.com/ document/ 73574364/El-Laberinto-de-La-Choledad. 
En Bolivia, las relaciones raciales también marcan jerarquías sociales. Espinoza analiza las relaciones entre la élite chola y la élite política. ${ }^{28} \mathrm{Argu}-$ menta que existe una élite chola asociada al comercio informal, contrabando, y redes económicas informales, con ancestro aymara. Hoy la identidad chola es más amplia, son inmigrantes que asumen identidad urbana, diferente al habitante no indígena.

La interseccionalidad entre política y racialidad es explorada por Van Cott. ${ }^{29}$ La autora examina la participación de Pachacutik en Ecuador y MAS en Bolivia, y sostiene que valores como solidaridad y consenso se han institucionalizado en asambleas indígenas, donde se trabaja en democracia deliberativa. Mark Sawyer explora el mito de democracia racial e inequidades en las décadas de los ochenta y noventa Latinoamérica. ${ }^{30} \mathrm{~A}$ partir de los noventa ha surgido un activismo político racial en Bolivia, Ecuador, Perú y Honduras. Con el fin de asegurar atención y prestigio internacional, los países se encargan que indígenas tengan oportunidades políticas y electorales, a través de acciones afirmativas.

Según García Linera, intelectual boliviano y actual vicepresidente, las prácticas políticas plebeyas, comunales y obreras son contrarias a la forma moderna de hacer política y su expansión a todo el espacio público es una posibilidad en contra de la despolitización. Esta expansión significaría "una ampliación de la democracia, a partir de un arranque de iniciativa social que reinventaría el significado de ciudadanía como acto de responsabilidad permanente de cada persona en el destino de las demás". ${ }^{31}$ Para García Linera el modo moderno y racional de hacer política supone que quienes deben pactar y representar los intereses sociales son las élites. Esta forma de hacer política -para el autor- necesita de un individuo desprovisto de los circuitos de filiación comunal. Mientras que la potencia plebeya son fuerzas emergentes de sectores sociales excluidos de la toma de decisiones, que actúan corporativamente y/o comunitariamente, y que buscan autorrepresentarse. Este sentido de política plebeya lo retomo para mi estudio: la política desplegada por los cholos políticos, tradicionalmente excluidos, carece de estas marcas individualistas de la modernidad y reivindica lo comunitario, la asamblea.

28. Fran Espinoza, “Bolivia, élite sectorial chola y élite política: Las ambivalencias de su relación", Anuario de acción humanitaria y derechos humanos, n. 11 (2013), http:/ / www. deusto-publicaciones.es / deusto/ pdfs / anuario/ anuario11.pdf.

29. Donna Lee Van Cott, Radical Democracy in the Andes (Cambridge: Cambridge University Press, 2008).

30. Mark Sawyer, “ 'Race' to the Future: Racial Politics in Latin America 2015”, Perspectives on Politics 3, n. ${ }^{\circ} 3$ (septiembre 2005): 561-566, http: / / www.jstor.org/stable/3689032.

31. Álvaro García Linera, La potencia plebeya. Acción colectiva e identidades indígenas, obreras y populares en Bolivia (Ciudad de México: CLACSO / Siglo XXI, 2015), 193. 
Otra vertiente conceptual provechosa para esta investigación es aquella referente a la politización de la ruralidad. Pécout sistematiza dos modelos diferentes de entender este proceso en el caso de Francia, uno es el francés denominado "politización precoz", cuyos representantes son Maurice Agulhon y Philippe Vigier, quienes ubican "el descenso de la política a las masas", entre 1830 a 1851. Y, otro, el "modelo americano tardío", construido por Eugen Weber y Suzanne Berger; para ellos el proceso de politización en Francia, ocurre en la Tercera República. ${ }^{32}$ De acuerdo a Weber la politización rural constituye la integración nacional del campo y de sus habitantes, los campesinos.

Estos autores se decantan por una interpretación de politización rural desde un enfoque de construcción del Estado nacional. Los cholos campesinos cuencanos que investigo también advirtieron, en esta fase de la modernización neoliberal del Estado ecuatoriano, que podían incidir en las políticas locales y aún nacionales, como examinaremos más adelante.

Pécout y Verger citan una tipología de lo que denominan "las conmociones rurales", elaborada por Jacquart, un nivel básico tendría que ver con conflictos de intereses de campesinos, y otro con "movimientos que enfrentan el mundo rural a los demás grupos sociales y a las estructurales englobantes: instituciones y ambiciones urbanas". ${ }^{33}$ El mundo rural se muestra como "psicológicamente indócil" o, a su vez, como "idílico y pacífico". Lo político parece resultar extraño al mundo rural y a su propio hábitat. ${ }^{34}$ En el caso de Cuenca, la amplia construcción literaria bucólica de los nobles y letrados cuencanos, da cuenta de esta percepción sobre ruralidad. ${ }^{35}$

Me quiero referir al concepto de sociabilidad que ha sido influyente al caracterizar la politización de la ruralidad. Para el historiador Maurice Agulhon, el concepto de sociabilidad es inseparable de política. La sociabilidad, es decir la calidad de ser sociable, equivaldría a "los sistemas de relaciones que confrontan a los individuos entre ellos o que los reunifican en grupos más o menos naturales, más o menos contrarios, más o menos estables". ${ }^{36}$ En este sentido, encuentro que la sociabilidad de líderes políticos parroquiales es uno de los mecanismos que contribuyeron a una politización precoz. Este

32. Jordi Canal, "Maurice Agulhon: historia y compromiso republicano", Historia Social, n. 29 (1997): 59, http:/ / www.jstor.org/ stable/ 40340623.

33. Gilles Pécout y Eduard J. Verger, "Cómo se escribe la historia de la politización rural. Reflexiones a partir del estudio del campo francés en el siglo XIX" , Historia Social, n. ${ }^{\circ}$ 29 (1997): 46, http:/ / www.jstor.org/ stable/ 40340625.

34. Ibíd., 102.

35. Adrián Carrasco, "Cuatro esquinas desde donde mirar a Cuenca". En Cuenca de los Andes (Cuenca: Municipalidad de Cuenca / Casa de la Cultura Ecuatoriana, 1998): 38-45.

36. Canal, "Maurice Agulhon: historia...", 64. 
sistema de relaciones que confronta individuos o los reagrupa, se construyó tanto internamente a la parroquia como externamente a ella. Líderes parroquiales se reagruparon como colectivo de parroquias rurales de Cuenca, mostrando así un poderío inusitado.

Las cholas cuencanas mujeres son transmisoras de cultura e identidad en la ciudad y región. ${ }^{37}$ El compañero de la chola se mueve en ambigüedad tanto por su nominación, atuendo y rol. La antropóloga Brownrigg comprobó que "chola" era una denominación que los habitantes del área urbana le daban a la mujer, mientras que "campesino", "indio", "de clase baja" eran formas como se referían a los varones. ${ }^{38}$ En efecto, en las entrevistas que examino más adelante, los líderes políticos parroquiales varones se autoidentifican no como cholos, sino como campesinos o habitantes rurales. ${ }^{39}$ No obstante, he optado en este estudio por inscribirlos en lenguaje de la "racialidad" al llamarlos cholos políticos. Lo cholo se opone a lo noble, en Cuenca; lo plebeyo comparte con lo cholo esta oposición, pero no es idéntico, más bien es adjetivación de lo que actores cholos hacen o ejecutan, como lo analizaremos en el siguiente acápite.

\section{EL PROCESO DE CONFORMACIÓN DE CIUDADANÍA PLEBEYA: DEMANDAS, PRÁCTICAS Y DISCURSOS}

Cuenca es una ciudad-región con tradición política conservadora, allí una supuesta aristocracia formaba parte de construcción de la dominación. El abolengo y un poder letrado fueron las estrategias para construir la dominación política. He planteado que, una vez fracasada la posibilidad de disputar el centro político con Quito en el siglo XIX, Cuenca apuesta por distinción en arena cultural, y se construye el imaginario de la "Atenas" del Ecuador que luego ha sido recreado con nuevas estrategias como la construcción del imaginario de patrimonialidad. ${ }^{40}$

En la década de 1990 se provoca una relativa ruptura del proceso anterior, y se posiciona un gobierno local de nueva izquierda que reivindicaba participación, y retomaba discursos de nuevos movimientos sociales. A pe-

37. Mancero Acosta, Nobles y cholos: Raza...

38. Leslie Ann Brownrigg, "The Nobles of Cuenca: The Agrarian Elite of Southern Ecuador" (tesis de doctorado, Columbia University, 1972).

39. El actual alcalde de la ciudad de Cuenca, Marcelo Cabrera, es conocido con el apelativo de "chola Cabrera". Esta referencia alude al hecho de que es un hombre grueso, blanco, rubicundo, alto. Curiosamente el apelativo es en género femenino, dando cuenta de contundencia de identidad femenina en la región.

40. Mancero Acosta, Nobles y cholos: Raza... 
sar de ser un gobierno local que asentaba su prestigio en el abolengo -el alcalde Fernando Cordero procedía de una de las familias de alcurnia de la ciudad-, también mostraba signos de renovación. Uno de los actores más potentes para impulsar transformaciones democráticas fueron los líderes políticos parroquiales. Ellos presionaron al alcalde, a la municipalidad y a la ciudad para ser tomados en cuenta, demandaron recursos económicos y autonomía, así como reconocimiento en tanto que interlocutores legítimos.

De parte del alcalde hubo no solo apertura, sino también voluntad política para basar su gestión en el desarrollo local y empoderamiento de las parroquias rurales. No obstante, este proceso no fue radical. Persistían desconfianzas, prejuicios y representaciones raciales que obstaculizaron su concreción y que se proyectan hasta la actualidad.

En la transición del nuevo siglo, en el ámbito nacional vivimos la asfixia del Estado neoliberal acompañado de crisis económica. La descentralización fue una estrategia del neoliberalismo para que el Estado se desentienda de sus responsabilidades y trasladarlas a localidades, así como al denominado tercer sector. En este contexto surgen demandas de parroquias rurales, lideradas por sus dirigentes.

La política tradicional de notables era de "vocación", hasta la década de 1970. Luego se ha posicionado más bien una política tecnocrática, que privilegia el saber experto de actores urbanos que tienen reconocimiento social. Sin embargo, durante década de 1990 emergen actores plebeyos, y más claramente cholos, que empiezan a reivindicar derechos y participación.

La emergencia del "cholerío" en política no es casual y está imbricada con la inyección de recursos económicos, prestigio y reconocimiento, fruto de la migración internacional. La participación está determinada sobre todo en asociaciones de juntas parroquiales que tienen un protagonismo inusual, se posicionan frente al Municipio y al Consejo Provincial, exigen sus derechos, negocian términos de su participación, y le dan nuevos sentidos a descentralización y participación de carácter neoliberal.

\section{La parroquia rural}

En este apartado mi intención es describir un proceso acelerado vivido en las parroquias rurales del cantón Cuenca, que implicó una politización también apresurada de sus líderes, durante el decenio 1995-2005; sin embargo, actualizo información pertinente sobre el proceso en curso.

La parroquia rural en Ecuador deviene en un gobierno local luego de un proceso histórico de larga data. Los corregimientos y los cacicazgos son reemplazados por la parroquia que constituye una forma moderna de la sociedad y del Estado. En este contexto, la comuna, pese a su debilitamiento 
por la descampesinización, sigue vigente jurídicamente y no ha dejado de ser "una instancia de toma de decisiones y de relaciones de parentesco". ${ }^{41}$ Incluso, en determinados territorios, se constituye es un medio de articulación con el Estado. ${ }^{42}$ Sin embargo, la parroquia fue el espacio que unificó las escisiones establecidas en el régimen colonial de la república de indios y de la república de españoles.

Andrés Guerrero nos dice que la parroquia sería la "infraestructura" política sobre la que se levanta el Estado nacional ecuatoriano; una suerte de "aparato" especializado en intermediación étnica, para articular la dominación sobre la población indígena por parte de la minoría dominante hispanoparlante. ${ }^{43}$ De ahí que el teniente político -siguiendo su reflexión- ${ }^{44}$ consolida la soberanía del Estado nacional de cara a los indígenas, desde fines de siglo XIX. Ese rol hoy ha cambiado, concentrándose en funciones de carácter administrativo antes que interétnico.

Las juntas parroquiales "surgieron como nivel de gobierno a partir de la Constitución de 1945 [...] sus funciones básicas fueron operar las decisiones de los Concejos Municipales". ${ }^{45}$ En la Constitución de 1998 se reconoció la junta parroquial como gobierno local. Posteriormente, en el 2000, se expidió la Ley de Juntas parroquiales, su reglamento, y se crearon asociaciones de juntas como el Consejo Nacional de Juntas parroquiales rurales del Ecuador CONAJUPARE, y Asociaciones provinciales. Este desarrollo jurídico-político se vivió acompañado por varios procesos de construcción locales, que evidenciaron una eclosión de participación, descentralización, desarrollo local. Municipios como Cotacachi, Guamote y Cuenca, algunos en la provincia de Tungurahua han sido estudiados como procesos emblemáticos.

La literatura sobre los municipios indígenas ha profundizado el análisis acerca tanto de las implicaciones para el movimiento indígena ecuatoriano en su apuesta por el poder local, así como por los efectos de ese poder local en los territorios e identidades. La penetrante investigación del equipo dirigido por

41. Alejandra Santillana Ortiz, "Proceso organizativo y límites del proyecto político de Pachakutik". En En las fisuras del poder. Movimiento indígena, cambio social y gobiernos locales (Quito: Instituto de Estudios Ecuatorianos / CLACSO, 2006), 259.

42. Karen Ortega, "Hegemonía comunal: Caso de estudio de la comuna de Toglla" (tesis de maestría, FLACSO Ecuador, 2015), 23, http:/ / hdl.handle.net/10469/8626.

43. Andrés Guerrero, "Curagas y tenientes políticos: La ley de la costumbre y la ley del estado (Otavalo 1830-1875)", Revista Andina 7, n. 2 (diciembre 1989): 321, http: / / www. iheal.univ-paris3.fr/ sites / www.iheal.univ-paris3.fr / files / 167034449-Andres-GuerreroCuragas-y-tenientes.pdf.

44. Ibíd.

45. Soledad Naranjo, "Análisis del rol de las juntas parroquiales rurales el cantón Pelileo en los procesos de desarrollo local" (tesis de maestría, FLACSO Ecuador, 2010), 32, http: / / hdl.handle.net/10469/3035. 
Ospina argumenta que "las mejores condiciones para profundizar el cambio social y la dirección política se encuentran en organizaciones rurales" ${ }^{46}$ Estas organizaciones han creado capacidades propias para dirigir su desarrollo y mantener el control sobre el territorio rural. Particularmente, interesa para mi estudio la concepción de "democracia neocorporativa", según la cual "la base de representación y la distribución económica depende de la adscripción organizativa". ${ }^{47}$ Sin embargo, resulta pertinente poner atención a la advertencia que hace Santillana, en este mismo texto, acerca de las dificultades en articular lo local con lo nacional, ya que a pesar de que se plantea una democracia "desde las bases organizadas, se obstaculiza cuando no se plantean estrategias nacionales que permitan incluir estas decisiones locales" ${ }^{48}$

En el caso de Cuenca, como analizamos más adelante, se percibe una articulación de este proyecto local con el proyecto regional, aunque no ausente de tensiones. Sin embargo, a diferencia de una amplia literatura que se focaliza en los municipios indígenas, en este estudio, son actores no autorreconocidos como indígenas, tampoco cobijados bajo el paraguas de las organizaciones o de partidos indígenas. En este artículo exploro no las condiciones que posibilitaron la emergencia de estos actores con voz propia, sino por los efectos que han traído para las politicidades en la región.

En el cantón Cuenca existen 21 parroquias rurales, que agrupan al $34,74 \%$ de la población total del cantón. ${ }^{49}$ Estas parroquias tienen una dimensión estratégica puesto que circundan a la ciudad y constituyen, parcialmente, las abastecedoras de productos alimenticios. En ellas existían juntas anteriormente, pero no eran elegidas por votación popular. Por lo cual estos organismos manejaban recursos escasos derivados de administración de sus mercados y cementerios, y no había empleados, sueldos, ni locales propios y equipados donde funcionaran: ${ }^{50}$

En Cuenca, desde el año 1996 se empieza una dinámica de trabajo entre el Municipio y las parroquias rurales, durante la alcaldía de Cordero. Esto toma fuerza entre los años 2000 a 2004. Para el 2000 se promulga la Ley de Juntas Parroquiales, pero sin reglamentos, sin presupuestos. Entonces lo que hace el Arq. Cordero

46. Pablo Ospina Peralta, "Movimiento indígena ecuatoriano, gobierno territorial local y desarrollo económico: los casos del Gobierno Municipal de Cotacachi y el Gobierno Provincial de Cotopaxi". En En las fisuras del poder..., 109.

47. Ibíd., 108.

48. Santillana Ortiz, "Proceso organizativo y límites...", 264.

49. Dato calculado en base a información del Instituto Nacional de Estadística y Censos (INEC), “Tabla: Población por área, según provincia, cantón y parroquia de empadronamiento", www.inec.gob.ec/tabulados.../1_POBL_PROV_CANT_PARR_AREA.xls.

50. Carlos García (presidente del Gobierno Autonónomo Descentralizado de Paccha), en conversación con la autora, abril de 2015. 
es que, mediante los presupuestos participativos y convenio, asigna partida presupuestaria para las 21 parroquias del cantón Cuenca, de acuerdo a necesidades insatisfechas, extensión territorial, población. ${ }^{51}$

Las juntas parroquiales debían decidir acerca de las obras y ejercer control sobre ellas. Las decisiones debían tomarse mediante asambleas participativas, de tal forma que se genere consenso en base a necesidades reales de la población. El Municipio asesoraba a las juntas en aspectos administrativos, legales y logísticos para que las decisiones sigan los canales legales y administrativos requeridos. Además, asignaba recursos para la realización de estas obras y apoyaba su proceso de ejecución.

Sin embargo, esta dinámica cambió rápidamente, porque los líderes parroquiales demandaban hacer obras, y no simplemente planificarlas, y el Municipio lo consintió. Estas parroquias se posicionaron más dinámicamente como gobiernos locales cuyas experiencias eran singulares, y podían ser replicadas en otros lugares:

Esta experiencia de presupuestos participativos de las Juntas Parroquiales de Cuenca fue factor clave para que a nivel nacional se exija que presupuestos participativos consten año tras año [...] Entonces en el CONAJUPARE veían la experiencia de Cuenca que era única en el país, porque las otras Juntas seguían siendo entes de gestión, de hacer un oficito, ir al Municipio, al Consejo Provincial a decir hagan esta obra y nada más. Pero en Cuenca nosotros ya ejecutábamos las obras, administrábamos los recursos económicos. ${ }^{52}$

El proceso de cambio fue paulatino, pero a la vez acelerado, porque al inicio se les asignaron recursos económicos pero el Municipio era el encargado de ejecutar; posteriormente se empezó a cuantificar la mano de obra; y luego se transfirió a la junta parroquial la ejecución de las obras.

Las formas de organización en las parroquias eran heterogéneas, desde comités promejoras, juntas comunales, comités de desarrollo hasta asambleas generales: "Una vez que se dio la transferencia de recursos económicos, nosotros como gobiernos parroquiales, a través de las asambleas identificamos los proyectos que se iban a ejecutar en cada comunidad"..$^{3}$

La ruralidad es el espacio en el cual viven y se activan políticamente los líderes cholos. El espacio no es un sitio neutro, sino una construcción social. La forma de ocupar espacios también es parte de este proceso de racialización. Romero afirma que cuestiones como color de la piel, acentos, religión,

51. Celso García (presidente de la Junta Parroquial de Ricaurte), en conversación con la autora, junio de 2012.

52. Ibíd.

53. Ibíd. 
pero también formas de ocupar el espacio pueden convertirse en significativas, "marcando" determinados cuerpos, espacios y representaciones. ${ }^{54} \mathrm{En}$ esta investigación, he advertido que la ruralidad en el caso del cantón Cuenca es un espacio marcado por un proceso de racialización. Provenir de la ruralidad, ser "campesino", ha sido una fuente de discriminación, que ha decantado en la arena política de forma significativa.

\section{Las demandas de los cholos políticos}

Las demandas de dirigentes rurales se relacionaban con dos niveles, uno material vinculado con la realización de obras de servicios básicos, pero también con aspectos de reconocimiento de lo rural, de afirmación de sus pobladores como habitantes dignos, y sus líderes como interlocutores políticos legítimos, frente a la ciudad.

Los líderes parroquiales demandaron tener poder de decisión para ejecutar obras que mejoren sus condiciones de vida. Ellos enfatizaron que hay obras indispensables, no obstante, tuvieron que priorizar cuáles ejecutar. Además, querían tener autonomía para planificar y ejecutarlas: "Somos gobiernos de más cercanía a la ciudadanía. Acá vienen a pedir las carreteras, vienen a pedir las obras. A la alcaldía no van a llegar. Y es ilógico que la alcaldía trate de planificar el desarrollo de una parroquia". ${ }^{55}$

La tensión se provoca, y continúa de este modo, porque las juntas demandan mayor equidad en distribución de recursos, puesto que ellas aducían que el 95\% se concentra en zona urbana y el restante en área rural. ${ }^{56}$

La participación de habitantes de parroquias rurales subió de forma exponencial, desde los barrios pasando por colegios e Iglesia hasta llegar a asambleas generales. La participación era parte de exigencia de la ley ${ }^{57}$ Esta política establecía, sin embargo, una tensión permanente entre un enfoque neoliberal y otro de democracia radical. Para ambos enfoques, aunque por motivos dis-

54. Romero, "Los desplazamientos de la raza...", 113.

55. Luis Quinde (presidente de la Junta Parroquial de Turi), en conversación con la autora, agosto de 2012.

56. La inequidad es todavía mayor, puesto que es apenas el 3,82\% (dato calculado). "Presupuesto Anual", Alcaldía de Cuenca, http:/ / www.cuenca.gov.ec/ ?q=node/1320; "Presupuestos Participativos, un reto para gobiernos locales", El Mercurio, 12 de mayo de 2010, http:/ / www. elmercurio.com.ec/239301-presupuestos-participativos-un-reto-para-gobiernos-locales / \#.

57. La Ordenanza n. ${ }^{\circ} 136$ está vigente desde el 25 de abril de 2001. Véase GAD Municipal del Cantón Cuenca, "Ordenanza de apoyo municipal a las juntas parroquiales rurales del Cantón Cuenca”, http: / / www.cuenca.gob.ec/ ?q=node/8840; y la Ordenanza n. ${ }^{\circ} 281$, publicada el 19 de enero de 2009, “Ordenanza que norma la participación ciudadana y cogestión de los presupuestos participativos con las parroquias rurales del Cantón Cuenca", http: / / www.cuenca.gov.ec/?q=node/ 8984 . 
tintos, la participación ciudadana fue puesta en el centro de la escena política.

De acuerdo con Van Cott, valores como solidaridad y consenso se han institucionalizado en asambleas indígenas, donde se trabaja a través de un proceso de democracia deliberativa.$^{58}$ Esta suerte de democracia deliberativa trataba de ser impulsada por los cholos políticos. En el caso de Cuenca, la promoción de participación en lo rural procede de discursos neoliberales promovidos por innumerables agencias, la academia y el Estado.

Se provocó apertura por parte del Municipio, y ese fue un momento de oportunidad política -en el sentido que da al concepto Tilly ${ }^{59}$ que se abrió para los cholos políticos de parroquias. Muestra de ello es que se procesan tres diferentes ordenanzas en el seno del concejo cantonal, destinadas a:

- Fortalecimiento de comités comunitarios y juntas parroquiales;

- Administración del equipamiento comunitario;

- Mantenimiento vial en la zona rural.

\section{Discursos y estrategias de los líderes parroquiales rurales}

Los cholos políticos constituyeron una asociación poderosa que dialogaba con el alcalde y los directores municipales. Se dieron cuenta de que, para poder negociar con el poderoso Municipio de Cuenca, necesitaban articular sus demandas:

La Asociación fue acogida por todas las Juntas porque era importante para hacer fuerza $[. .$.$] entonces si alguna vez se trataba de hacer algún paro podíamos$ hacerlo [...] Las 21 juntas se reunieron y creamos un directorio que se encargaba de ser el nexo entre el Municipio y las Juntas [...]. Lo bueno es el hecho de que se aprovechó la oportunidad, porque como era una trocha recién abierta, por un lado, tener un alcalde que nos tuvo las puertas abiertas; y, la otra es que nos dimos cuenta de que si íbamos solos éramos menos fuertes, en cambio, si nos uníamos teníamos más presión. ${ }^{60}$

Cuenca, una ciudad ubicada al sur del país, siempre ha denunciado el centralismo de Quito, su capital. En la relación del centro político urbano con

58. Van Cott, Radical Democracy in the Andes.

59. Plantea un modelo de acción compuesto de interés, organización, movilización, acción colectiva y oportunidad. Oportunidad describe la relación entre el interés de la población y el estado del mundo circundante. Véase Charles Tilly, "From Movilization to Revolution". Working Paper. University of Michigan, 1977. deepblue.lib.umich.edu/ bitstream/handle/2027.42/50931/156.pdf. Traducción de la autora.

60. Carlos García, en conversación con la autora. 
sus periferias se dio una situación sui generis, puesto que líderes políticos usaron esos mismos discursos, pero para interpelar al centro urbano:

Nuestra política era que queríamos administrar los recursos económicos, porque podíamos abaratar costos, porque teníamos la mano de obra, que ya no se llamaba no calificada porque en todas las parroquias teníamos buenos maestros albañiles y teníamos buena decisión e intención; porque si construíamos para nosotros mismos lo íbamos a construir con más cariño y ya no se trabajaba en horario, sino con mingas. ${ }^{61}$

La población rural resignificó esos discursos, les importaba adquirir poder de decisión y realizar sus obras. En parroquias rurales se encuentra afincado mucho del saber artesanal, de oficios, entre ellos la construcción. Los maestros albañiles que construyen las obras de la prestigiosa arquitectura cuencana, destinada a viviendas de élites urbanas, provienen de estas zonas. Asimismo, la minga, una institución social milenaria utilizada en nuestras comunidades indígenas, rápidamente fue refuncionalizada con un discurso participativo: “Uno de las estrategias para poder apoyar esta voluntad política que tenía Cordero, fue que primero nos consolidemos en las parroquias, luego aliarnos a otras juntas parroquiales, formamos el Consorcio de Juntas y entonces en grupo, asistíamos a las reuniones del Consejo Cantonal". ${ }^{62}$

Este inusual y sorpresivo empoderamiento no fue siempre avalado por la población rural, quienes pensaban que la junta "era un comité más" y no necesariamente lideraría el desarrollo de la parroquia. Pero también se pretendía contrastar la forma clientelar de establecer lazos políticos entre el centro y las periferias, inaugurando así formas novedosas de entablar estas relaciones, basadas en derechos:

Como éramos gobiernos parroquiales nacientes nadie daba credibilidad a las Juntas porque decían es un comité más, no tenemos recursos y sin recursos, qué obras van a hacer. Entonces varios líderes comunitarios querían seguir manteniendo esa forma de hacer gestión, mientras más amigo es del alcalde, del prefecto puede sacar más obras, mientras que quien no es amigo se queda fuera. Entonces, cambiar esa dinámica fue duro, había una cierta resistencia. ${ }^{63}$

Los líderes parroquiales no se confunden acerca de cuál era su propósito y estrategia. Ellos, igual que las cholas mujeres vendedoras del mercado, pedían respeto. ${ }^{64} \mathrm{El}$ respeto tenía que ver con su carácter de entidad pública

61. Ibíd.

62. Celso García, en conversación con la autora.

63. Ibíd.

64. Mancero Acosta, Nobles y cholos: Raza... 
que era reconocida en la Constitución, aunque en la práctica no lo lograba. Al mismo tiempo, podemos percibir unas prácticas solidarias entre las parroquias, relacionadas con el espíritu comunitario:

Cuando se formó el Consorcio la meta era que podamos exigir tanto al Gobierno Nacional como a gobiernos locales que se nos respete como entidades públicas. Luego, que se den asignaciones para poder administrar y funcionar. Hicimos una especie de reglamento, una de las cláusulas decía que mensualmente debe reunirse el Consorcio, hacíamos las reuniones un mes en Turi, otro mes en Tarqui, y así. Si alguna parroquia estaba rezagándose buscábamos que se fortalezca. ${ }^{65}$

En una entrevista reciente, pude percibir que objetivos por los que trabajaron líderes parroquiales no siempre se concretaron, las prácticas clientelares del manejo político continuaron, la unidad de las juntas en el Consorcio continúa siendo una quimera, y líderes continúan demandando respeto desde las instancias políticas urbanas:

Se viven las formas tradicionales de manejar la política. En este momento somos políticos, pero queremos diferenciarnos de los políticos tradicionales que hacen obra por clientelismo, o por el que está en mi partido. Lo estoy viviendo en carne propia. Debería cambiar, he conversado con mis compañeros y les he dicho que no debemos manejar una agenda propia sino una común para las 21 parroquias. Ahí es cuando nos van a respetar. ${ }^{66}$

Todos los líderes entrevistados se definieron como políticos. Ellos están claros que no son simples gestores de obras o intermediarios, aunque diferencian entre políticos y politiqueros. Los políticos son quienes practican "el arte de servir a una parroquia, a una comunidad". Se consideran "personas que tienen ganas de trabajar de la mejor forma por el grupo", se identifican como "una persona que siente la satisfacción que está haciendo algo por la gente que está a su alrededor". ${ }^{67}$

Están prevenidos de que la "politiquería" causa mucho daño a la parroquia, y está vinculado con el hecho de buscar su bienestar personal y no el de todo el grupo: "Una cosa podríamos definir que es la política como servicio a la comunidad y otro la politiquería, entonces yo si me considero un político"; "La política es el arte de servir a una parroquia, a una comunidad, la politiquería es otra cosa". ${ }^{6}$

65. Celso García, en conversación con la autora.

66. Luis Quinde, en conversación con la autora, agosto de 2012.

67. Ibíd.

68. Ibíd. 
El enlace entre el Municipio y las juntas durante una etapa de alcaldía de Cordero fue una funcionaria mujer. Los líderes políticos, la mayor parte hombres, apreciaban que ella hiciera este nexo. Sin embargo, tenía que interactuar solo con hombres puesto que las juntas parroquiales estaban, $y$ continúan así, mayoritariamente representadas por hombres.

La hegemonía de hombres en las parroquias rurales da cuenta de que estas parroquias y sus habitantes han demostrado ser impermeables a la agenda de género desarrollada en la ciudad de Cuenca por ONG y movimientos de mujeres. Cuenca se precia de tener múltiples ordenanzas y acciones de equidad, no obstante, un techo de cristal no permite avanzar en las parroquias rurales: "Ella fue el nexo directo, nos coordinaba, era -según nosotros"la mamá de las Juntas", porque era la que llevaba de un lado a otro a los presidentes que teníamos inconvenientes, tal vez por papeles, documentos, justificativos" ${ }^{69}$

En la última elección de 2014, solo hubo dos candidatas mujeres para dirigir juntas parroquiales, ellas pertenecían a las parroquias de San Joaquín y de Paccha. Las otras listas únicamente ponían a mujeres como vicepresidentas. Esto originó un reclamo de una veeduría ciudadana porque se estaba incumpliendo con la ley que determina secuencialidad y alternabilidad, una lucha histórica de los movimientos de mujeres en este país. ${ }^{70}$

Otro aspecto que destacan los líderes es que los cambios que se propiciaron con su incursión directa en la política, implicaron un proceso de democratización social en el territorio y en la población:

Cuando se empezó a manejar desde el 2000 los dineros, se dieron cuenta que es un manejo mucho más práctico, mucho más democrático. Hasta políticamente, se dieron cuenta que hay una cantidad de gente porque si son alrededor de 790 juntas en el nivel nacional, solo por 5 miembros de la junta jcuántos directivos hay a nivel nacional! ${ }^{17}$

Los líderes parroquiales se llaman los representantes a superar una política clientelar, sin embargo, no podemos idealizarlos. Ya hemos hablado de sus prácticas poco equitativas en términos de género, y, al analizar los datos que tengo del período de emergencia de las juntas en el año 2000 a 2004, y en 2014, he podido observar muy poca renovación de los cuadros de los líderes parroquiales.

69. Carlos García, en conversación con la autora.

70. "Presidentes de las Juntas Parroquiales buscan ser reelegidos", El Mercurio, 29 de noviembre de 2013, http: / / www.elmercurio.com.ec/407669-15-presidentes-de-juntasbuscaran-ser-reelegidos /.

71. Carlos García, en conversación con la autora. 
En las últimas elecciones de los gobiernos locales en 2014, 15 de 21 líderes de las parroquiales rurales del cantón Cuenca buscaron la reelección. ${ }^{72}$ Esto puede significar, por un lado, la persistencia de prácticas de caudillismo y de escasa alternabilidad que afectan la democracia, pero también puede ser el reflejo de bajas capacidades y liderazgos que se desarrollan en la zona rural del cantón, lo cual tiene que ver con la ausencia de educación y acceso a recursos culturales.

La inequidad en la distribución de recursos entre el área urbana y rural en el cantón es lacerante. Las brechas se manifiestan en algunos de los servicios básicos. ${ }^{73}$ Así, por ejemplo, en relación con el agua potable, en promedio, el 64,31\% de hogares rurales gozan del servicio de la red pública, mientras que el $96,54 \%$ de hogares urbanos tienen acceso. Con un promedio de $26,51 \%$, la principal fuente de agua de los hogares de parroquias rurales es un río, vertiente o acequia.

En cuanto al alcantarillado, el promedio de los hogares de parroquias rurales que cuenta con este servicio es de apenas el 25,86\%, mientras que en la ciudad es del 93,91\%. El 41,41\% de los hogares de las parroquias rurales solo cuentan con pozo séptico. El 19,08\% de hogares rurales no tiene ningún tipo servicio higiénico o escusado.

Persisten brechas importantes en eliminación de desechos; en promedio, el 60,68\% de los habitantes rurales cuentan con servicio de recolección basura, mientras que el 98,62\% de la población de la urbe elimina los desechos de esa forma. En la parroquia de Quingeo, solo el 8,32\% de la población accede al servicio, el 73,50\% de la basura es quemada. El 13,66\% de los residentes de Chaucha acceden a este servicio, la mayor parte de la basura es quemada o arrojada a un terreno baldío o quebrada.

Los datos son disímiles respecto del centro urbano, pero también entre las propias parroquias rurales. Las diferencias en acceso a servicios entre las parroquias tienen que ver con varios factores como la proximidad o lejanía al centro urbano, la capacidad de gestión que las parroquias han ido acumulando históricamente, la propia gestión de sus dirigentes, la capacidad de presión de sus habitantes. En contrapartida, también guardan relación con el tipo de relación establecida entre los dirigentes parroquiales con la

72. "Presidentes de las Juntas Parroquiales buscan ser reelegidos", El Mercurio, 29 de noviembre de 2013, http: / / www.elmercurio.com.ec/407669-15-presidentes-de-juntasbuscaran-ser-reelegidos / \#.

73. La información de servicios mostrada a continuación ha sido tomada de Instituto Nacional de Estadística y Censos (INEC), "Información Censal Cantonal”, http:/ / www. inec.gob.ec $/ \mathrm{cpv} /$ index.php?option=com_content\&view=article\&id=232\&Itemid=128\&la $\mathrm{ng}=\mathrm{es}$. 
administración municipal, la afinidad política, o incluso, un cierto grado de clientelismo, entre el municipio y la parroquia.

No obstante, estos datos dejan en claro que la persistencia de la añeja contradicción ciudad/campo no ha sido superada. Nuevamente el espacio es una expresión no solo física sino también social, marcada por signos visibles de discriminación, jerarquía y racialización. Concuerdo con Nugent que en nuestras sociedades no vivimos la segregación de un modo tan dramático como en otras, sino una convivencia en medio de la subordinación. ${ }^{74}$ Además, si bien es cierto que los estudios de la nueva ruralidad enfatizan en la disolución de oposiciones binarias campo/ciudad, podemos notar que aún persisten desigualdades. ${ }^{75}$

De vuelta a las representaciones de líderes parroquiales rurales, algo que reverbera en la conversación con ellos es, por una parte, el orgullo de saberse protagonistas de un proceso de cambio en la región y en el país. Pero, por otra parte, hay una sutura no cerrada, un posicionamiento fuerte, pero siempre subordinados por debajo de la dinámica urbana. Esta subordinación se expresa no solo en términos de la distribución de recursos y acceso a servicios, como hemos examinado, sino también como un racismo silente del cual nos hablaba De la Cadena. ${ }^{76}$

En mi perspectiva, está claro que se trata de una injusticia de reconocimiento e injusticia de redistribución, como lo ha propuesto Nancy Fraser. ${ }^{77}$ En otras palabras, mi planteamiento es que la situación de lo rural en el cantón expresa un problema de clase articulado con identidad, en términos raciales y de género. Esta interseccionalidad de la problemática vuelve mucho más compleja la situación y su resolución.

Los líderes parroquiales están conscientes de que hay inequidad en la distribución de los recursos, aunque valoran positivamente el cambio ocurrido y las pequeñas obras que lograron las parroquias:

Siempre en la ciudad será en donde más inversiones se hacen porque se trata de la ciudad, pero igual yo creo que si han progresado algunas de las parroquias [...] No todavía, no hay equidad, en el sector urbano es en donde más se invierte la plata, en la apertura y arreglo de vías, en alcantarillado y más. ${ }^{78}$

74. Nugent, "El laberinto de la choledad...".

75. Luciano Martínez, "La nueva ruralidad en Ecuador: siete tesis para el debate", Iconos, n. ${ }^{\circ} 8$ (1999): 12-19, doi: 10.17141/iconos.8.1999.714.

76. De la Cadena, "The Racial Politics...".

77. Nancy Fraser, "Social Justice in the Knowledge Society. Redistribution, Recognition, Participation". (Paper Beitragzum Kongress "Gut zuWissen”, 1-13 (Heinrich BollStiftung, 2001).

78. Carlos García, en conversación con la autora. 
Pocos líderes parroquiales hablan de discriminación abiertamente; ante mis preguntas, uno de ellos explícitamente señaló que "no cree que haya discriminación porque cada uno tiene sus cosas". ${ }^{79}$ Cuando se refieren a las "cosas", pude notar que aflora un sentido de identidad rural que hace que se sientan, de cierta manera, moralmente superiores a los habitantes del área urbana:

Ese sí es un tema que nosotros florecimos, porque con la ley de Juntas Parroquiales recién se dieron cuenta de que existía el área rural, y de que nos podemos organizar más rápidamente y no teníamos tantos complejos, egoísmos, sino que veíamos una causa común. Y se puede decir, a los 10 años, lo que debía haber iniciado aquí en el cantón Cuenca, se inició en el área rural; y si usted ve ahora en el área urbana recién están haciendo lo que nosotros en el área rural ya hicimos hace 10 años. ${ }^{80}$

La relación entre el área urbana y rural en la región ha sido compleja. Históricamente, en Cuenca dominaban los señores de la tierra, quienes no poseían inmensas propiedades, pero sí fueron capaces de establecer estrategias de dominio a través de erigirse en un poder letrado y bajo una supuesta nobleza de sangre. ${ }^{81}$ No obstante, dado que había una convivencia quizás demasiado próxima con los indios y cholos de la región -en el sentido que lo ha recalcado Nugent- ${ }^{82}$ el patriarca noble y letrado fue capaz de aprender su idioma -cuando aún lo poseían-, de reflexionar sobre su realidad, e incluso de desarrollar una poesía bucólica que romantizaba una ruralidad sobre la cual estas mismas élites ejercían una explotación despiadada.

Una vez quebrado el sistema basado en un régimen de producción de la tierra, el área urbana ha dependido del área rural para el abastecimiento de productos alimenticios básicos, servicios, mano de obra. Los cholos políticos han imaginado trastocar el orden existente y superar la dependencia, así como el consabido peregrinar de gente rural hacia la ciudad: "Sí se logró uno de los ideales que se tenía desde las parroquias, que ya no se tenga que ir a Cuenca para todo, sino quedarnos aquí y que se conozcan nuestras áreas rurales y que se vayan conociendo las fortalezas que tiene cada una de las parroquias". ${ }^{83}$

Los líderes políticos admiten que hay inequidades, pero al mismo tiempo, rápidamente, reivindican lo que denominan sus propias fortalezas. A

79. Saúl Siavichay (presidente de la Junta Parroquial de Llacao), en conversación con la autora, agosto de 2012.

80. Carlos García, en conversación con la autora.

81. Mancero Acosta, Nobles y cholos: Raza...

82. Nugent, "El laberinto de la choledad...".

83. Carlos García, en conversación con la autora. 
través de este gesto, en mi perspectiva, los habitantes rurales procuran establecer un equilibrio para poder tolerar mejor esta dependencia e inequidad:

Hay inequidades porque unos tenemos mayores satisfacciones en ciertas áreas y otros no, pero sí existen inequidades. Pero también tenemos algunas fortalezas como el estar en el campo en un ambiente más sano, menos contaminado, hay menos inseguridad. Pero eso también trae la otra cara de la moneda, que no tenemos los servicios básicos necesarios, que nos faltan colegios, escuelas, nos falta salubridad. En cierta forma el sector urbano está atendido en algunas áreas, pero en otras no, también eso les trae enfermedades como el estrés, pero sí hay inequidades. ${ }^{84}$

\section{Campesinos versus técnicos}

De acuerdo con una nueva normativa, el sector rural cuenta con concejales propios. Esto ha tratado de establecer un equilibrio frente a la relación inequitativa entre estos dos mundos. No obstante, en la opinión de un líder, puede dar lugar a nuevas discriminaciones. Pude notar que el origen de la discriminación está en la percepción de "campesinos" de los habitantes rurales. Ser campesino es asociado con "gente que no sabe", "que no tiene los conocimientos", "que no hace bien las cosas". Por ello, distinguir a los concejales en urbanos y rurales constituye una puerta abierta a la discriminación, puesto que serán tildados de proceder del área campesina rural:

Siempre nos decían, ellos son del área rural y nosotros somos del área urbana y yo creo que, por ejemplo, ahora tenemos los concejales rurales, si bien es cierto los concejales rurales en el seno del concejo cantonal, todos ejercen la misma función, sin embargo, no dejan de ser concejales rurales, del área rural. Entonces considero que ese sí es un limitante, porque nos van a decir que somos del área campesina rural. ${ }^{85}$

Se desprende del discurso del líder parroquial que el establecimiento de dos tipologías de concejales, urbanos y rurales, se convierte en una desventaja: él la llama "limitante". Quizás en otros concejos cantonales menos marcados por las diferencias urbanas y rurales, medidas como estas puedan funcionar, sin embargo, habría que estudiar a detalle lo que ocurre en la ciudad de Cuenca en el concejo cantonal, en la actualidad, lo cual no ha sido el objetivo de este estudio, pero constituye una línea de investigación en el futuro. Sospecho que los "cholos políticos", y diríamos también las "cholas

84. Ibíd.

85. Celso García, en conversación con la autora. 
políticas" -dado que existen concejales rurales mujeres en el concejo cantonal en la actualidad-, no se pueden igualar fácilmente a través de asignarles una representación particular, sino más bien una universal.

En los discursos actuales salta nuevamente este problema, que en mi entender forma parte de este desdeño hacia la política plebeya, es lo que de forma incisiva un líder parroquial ha denominado una "urbanización" de la representación política parroquial: "Para Bolívar Saquipay los cinco concejales electos en representación de las parroquias rurales "se han urbanizado [...] quienes vivimos en la zona rural sentimos que falta trabajo de los concejales a favor del sector rural". ${ }^{86}$

De retorno al núcleo de mi investigación, luego de mis conversaciones con los líderes, pude entender algo que no había previsto: que la denominación aparentemente inofensiva por el lugar de donde provienen los habitantes, la denominación de "campesinos", es percibida como discriminatoria por parte de los líderes rurales. Ante mi pregunta: ¿considera que hay diferencias entre los habitantes del área urbana y rural?, contestaron:

Los de la parte urbana se sienten como de la ciudad y los del área rural nos califican como campesinos. Yo considero que estas diferencias se notan más en la parte política, porque en lo otro hay diferencias, pero como que no se sienten. Pero en el ámbito político sí se pueden observar esas diferencias. ${ }^{87}$

De este intrigante discurso se pueden desprender varias reflexiones. Primero, el rol activo que le otorgan los habitantes parroquiales a los urbanos, ellos son los que nominan a los otros, los campesinos son los otros, los nominados, por eso dice el dirigente entrevistado "nos califican como campesinos". Por otro lado, el dirigente rural al diferenciar entre la "parte política" y "lo otro", evidencia que es la política la arena en la cual las diferencias se exacerban y son más perceptibles. La sagacidad de los habitantes rurales muestra una realidad compleja pero persistente en Cuenca. La existencia de unos y otros, de urbanos y rurales, de citadinos y campesinos, de nobles y cholos.

En la arena política es donde estos líderes se enfrentaron a discriminaciones que tenían que ver con su aparente ignorancia en aspectos técnicos para gestionar sus parroquias. Veamos, por ejemplo, el siguiente fragmento de la entrevista:

86. “Concejales rurales se han urbanizado", El Mercurio, 13 de octubre de 2015, http:/ / www.elmercurio.com.ec/499127-cuestionamientos-apuntan-a-concejales-rurales / \#.

87. Celso García, en conversación con la autora. 
Se decidió como junta parroquial cerrar el cementerio con bóvedas. Cuando se construía, un ciudadano denunció en Planificación. Entonces un arquitecto del Municipio vino, hizo la inspección y en cierta forma con términos despectivos dijo que por ser campesinos ustedes no saben qué es el manejo y cómo se debe hacer qué es técnico. En ese momento yo le llamé al Arquitecto Cordero, quien dio la orden y refiriéndose a mi persona dijo "él sabe lo que hace en su comunidad, nuestra obligación es darle recursos y él administra, que le juzgue la comunidad a él y que no nos juzguen a nosotros" ${ }^{88}$

Podemos advertir la confrontación entre la dualidad "técnico-campesino" que a los líderes políticos parroquiales les ha incomodado recurrentemente. No ha sido precisamente "un diálogo de saberes", sino una confrontación persistente. El saber técnico se enfrenta al saber campesino, los expertos son poseedores de un conocimiento sistemático y títulos reconocidos otorgados por las universidades. Los campesinos, en cambio -desde la perspectiva de los técnicos- desconocen cómo hacer las cosas y se equivocan constantemente. Conocimiento y poder, como ya nos ha dicho Foucault, constituyen un binomio de la dominación. Ser campesino se ha trastocado de su significado original de la procedencia o proceder del campo, por "ser ignorante", "no poseer el saber técnico", "ser otro y distinto".

No obstante, en este fragmento también queda claro la autonomía que pudieron lograr durante la alcaldía de Cordero, lo cual desató esta confrontación subyacente, porque supuso un ir y venir permanente de los líderes parroquiales al Municipio, como de los funcionarios municipales a las parroquias. Los líderes parroquiales debían acercarse al Municipio tanto para mantener reuniones con el alcalde como para gestionar sus proyectos con los funcionarios. Pero también el alcalde dio la disposición de que los funcionarios municipales fueran a las parroquias para asesorar, in situ, a las juntas. Esta dinámica de encuentros y desencuentros generó intercambios, pero también una reverberación de las históricas discriminaciones surgidas a raíz de las diferencias sociales y culturales de estos grupos.

Este texto trasluce este empoderamiento que los líderes parroquiales experimentaron, que incluso les permitió tener un tono de sorna respecto al "saber técnico":

Cuando fuimos a inaugurar la vía llegó el grupo de funcionarios del Municipio a entregarnos papeles, y nos dijeron "tengan, aquí está un informe preliminar de factibilidad para hacer la vía". Entonces yo les dije "¿pero no se dieron cuenta por dónde vinieron? si ustedes supuestamente vinieron a hacer el estudio de factibilidad". Y me dicen que, lamentablemente, no podía hacer así la vía y les dije que no, no es que no pude hacer la vía, yo ya hice, lo que tal vez es que no debía,

88. Carlos García, en conversación con la autora. 
cosa que es muy diferente. Entonces ahí había una presión para los técnicos del Municipio porque la vía ya estaba construida por campesinos. ${ }^{89}$

De un rastreo sobre la situación de las juntas parroquiales en la administración en curso, puedo advertir que persiste una queja constante por falta de cumplimiento de asignaciones presupuestarias por parte del Municipio hacia las juntas parroquiales, ${ }^{90}$ así como la apelación constante a los discursos de participación ciudadana como un mecanismo de política plebeya. ${ }^{91}$ También se puede observar un debilitamiento de la organización parroquial, es decir del consorcio de juntas parroquiales. ${ }^{92}$

Un aspecto clave en la relación entre Municipio y parroquias rurales es el concepto de autonomía, así como el tipo de política que se establece entre el área urbana y el área rural:

Las Juntas Parroquiales partiendo de su sistema de organización dicen querer mantener la esencia de los presupuestos participativos y por tanto afirman "No queremos para nada una imposición técnica que nos venga desde el Municipio o Gobierno provincial, ellos tienen su otro sistema de planificación que la respetamos, pero nosotros vamos más abajo, a trabajar con toda la gente", puntualizó Saquipay. ${ }^{93}$

La política "más abajo" es la política que he llamado plebeya. La política plebeya no es la política de vocación, o que otorga prestigio a los nobles patricios cuencanos; es una política comunitaria, colectiva, para la vida, liderada por actores históricamente excluidos, desarrollada por los plebeyos, a quienes he denominado cholos políticos. De su despliegue dependen obras básicas para subsistencia y servicios, así como aspectos de reconocimiento y respeto. Es decir, se articulan elementos de clase e identitarios. La dinámica

89. Ibíd.

90. "Consorcio parroquial tiene nuevo directorio", El Tiempo, 29 de mayo de 2014, http:/ / www.eltiempo.com.ec/noticias-cuenca/143374-consorcio-parroquial-tiene-nuevo-directorio/.

91. "Presupuestos participativos, un reto para gobiernos parroquiales", El Mercurio, 5 de diciembre de 2010, http:/ / www.elmercurio.com.ec/239301-presupuestos-participativos-un-reto-para-gobiernos-locales/\#; "Asamblea parroquial priorizó necesidades", El Tiempo, 19 de septiembre de 2014, http: / / www.eltiempo.com.ec/ noticias-cuenca/149709asamblea-parroquial-prioriza-necesidades/.

92. "Consorcio parroquial tiene nuevo directorio", El Tiempo, 29 de mayo de 2014, http:/ / www.eltiempo.com.ec/noticias-cuenca/143374-consorcio-parroquial-tiene-nuevo-directorio/.

93. "Presupuestos participativos, un reto para gobiernos parroquiales", El Mercurio, 5 de diciembre de 2010, http:/ / www.elmercurio.com.ec/239301-presupuestos-participativos-un-reto-para-gobiernos-locales/\#. 
social y política generada en este espacio y período, e investigada en este trabajo, se resume en la frase que menciona el dirigente de la junta parroquial de Llacao, Saúl Siavichay: "Ese sí es un tema que nosotros florecimos".

Hoy los líderes parroquiales continúan teniendo problemas para hacer prevalecer su concepción de la política, sus prácticas participativas y siguen luchando frente al Municipio, sus autoridades y funcionarios que pretenden imponer sus propias prácticas y sus concepciones de una visión tecnocrática y despolitizada.

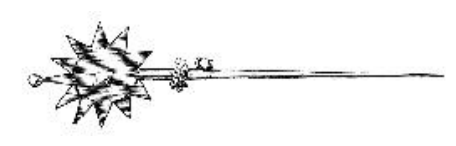

\section{FUENTES Y BIBLIOGRAFÍA}

FUENTES PRIMARIAS

\section{Documentos oficiales}

Alcaldía de Cuenca. "Presupuesto Anual”. 23 de agosto de 2016. http:/ / www.cuenca.gov.ec/?q=node/ 13207 .

GAD Municipal del Cantón Cuenca. “Ordenanza que norma la participación ciudadana y cogestión de los presupuestos participativos con las parroquias rurales del Cantón Cuenca". s. f. http:/ / www.cuenca.gov.ec/ ?q=node/8984. . "Ordenanza de apoyo municipal a las juntas parroquiales rurales del Cantón Cuenca". 23 de agosto de 2016. http:/ / www.cuenca.gob.ec/?q=node/ 8840.

INEC. Información Censal Cantonal 23 Servicios Básicos. s. f. http: / /www.inec.gob. ec $/$ cpv / index.php?option=com_content\&view $=$ article\&id=232\&Itemid=128 \&lang=es.

\section{Entrevistas}

García, Carlos. Presidente del Gobierno Autónomo Descentralizado de Paccha, en conversación con la autora. Agosto de 2015.

García, Celso. Presidente de la Junta Parroquial de Ricaurte. En conversación con la autora. Agosto de 2012.

Quinde, Luis. Presidente de la Junta Parroquial de Turi. En conversación con la autora. Agosto de 2012.

Siavichay, Saúl. Presidente de la Junta Parroquial de Llacao. En conversación con la autora. Agosto de 2012. 


\section{Periódicos}

El Tiempo. Mayo y septiembre de 2014.

El Mercurio. Mayo y diciembre de 2010; noviembre de 2013; octubre de 2015.

\section{FUENTES SECUNDARIAS}

Almeida, José. “Identidades en el Ecuador. Un balance antropológico". En Ciudadanía e identidad, compilado por Simón Pachano, 83-142. Quito: FLACSO Ecuador, 2003.

Becker, Marc. "Movimiento Unidad Plurinacional Pachakutik". En jPachakutik!: Movimientos indígenas, proyectos politicos y disputas electorales en el Ecuador, 49-80. Quito: FLACSO Ecuador / Abya-Yala, 2015.

Bretón, Víctor. "Desarrollo rural y etnicidad en las tierras altas de Ecuador". En Estado, etnicidad y movimientos sociales en América Latina. Ecuador en crisis, editado por Víctor Bretón y Francisco García, 217-253. Barcelona: Icaria, 2003.

Bourricaud, François. “¿Cholificación?”. En El indio y el poder en el Perú, 183-198. Lima: Moncloa / Campodónico, 1970.

Brownrigg, Leslie Ann. “The Nobles of Cuenca: The Agrarian Elite of Southern Ecuador". Tesis de doctorado. Columbia University, 1972.

Büschges, Christian. "Políticas de identidad entre integración y autonomía: movimiento indígena, sociedad y Estado en Ecuador y Nepal desde una perspectiva comparativa y transnacional". En Los Andes en movimiento. Identidad y poder en el nuevo paisaje político, editado por Pablo Ospina, Olaf Kaltmeier y Christian Büschges, 41-63. Quito: Universidad Andina Simón Bolívar, Sede Ecuador / Universidad de Bielefeld / Corporación Editora Nacional, 2009.

Canal, Jordi. "Maurice Agulhon: historia y compromiso republicano". Historia Social, n. ${ }^{\circ} 29$ (1997): 47-72. http:/ / www.jstor.org/ stable/ 40340623.

Carrasco, Adrián. "Cuatro esquinas desde donde mirar a Cuenca", 38-45. En Cuenca de los Andes. Cuenca: Municipalidad de Cuenca / Casa de la Cultura Ecuatoriana, 1998.

De la Cadena, Marisol. “¿Son los mestizos híbridos? Las políticas conceptuales de las identidades andinas". Universitas Humanística, n. ${ }^{\circ} 61$ (enero-junio 2006): 51-84. . "The Racial Politics of Culture and Silent Racism in Peru". Documento presentado en la Conferencia Racism and Public Policy. Durban: United Nations Research Institute for Social Development, 2001.

De la Torre Espinosa, Carlos. "Introducción". En Afroquiteños: Ciudadanía y racismo, 11-30. Quito: CAAP, 2002.

Espinosa, Manuel. Los mestizos ecuatorianos y las señas de identidad cultural. Quito: Tramasocial, 2000.

Espinoza, Fran. "Bolivia, élite sectorial chola y élite política: las ambivalencias de su relación". Anuario de acción humanitaria y derechos humanos, n. ${ }^{\circ} 11$ (2013): 141160. http:// www.deusto-publicaciones.es/deusto/pdfs/anuario/anuario11. pdf. 
Fraser, Nancy. "Social Justice in the Knowledge Society. Redistribution, Recognition, Participation". Ponencia Beitrag zum Kongress "Gut zu Wissen", 1-13. Heinrich BollStiftung. 2001.

García Linera, Álvaro. La potencia plebeya. Acción colectiva e identidades indígenas, obreras y populares en Bolivia. Buenos Aires: CLACSO / Siglo XXI, 2015.

Guerrero, Andrés. "Curagas y tenientes políticos: La ley de la costumbre y la ley del Estado (Otavalo 1830-1875)". Revista Andina 7, n. 2 (diciembre 1989): 321-365. http:/ / www.iheal.univ-paris3.fr/sites/www.iheal.univ-paris3.fr / files / 167034449-Andres-Guerrero-Curagas-y-tenientes.pdf.

Ibarra, Hernán. "La revaloración del cholo y la cholificación". En La otra cultura. Imaginarios, mestizaje y modernización, 15-17. Quito: Marka / Abya-Yala, 1998.

Kaltmeier, Olaf. "Estado, espacio y etnicidad: Prácticas y representaciones espaciales en Cotopaxi entre la mímesis y la alteridad". En Los Andes en movimiento. Identidad y poder en el nuevo paisaje político, editado por Pablo Ospina, Olaf Kaltmeier y Christian Büschges, 191-216. Quito: Universidad Andina Simón Bolívar, Sede Ecuador / Universidad de Bielefeld / Corporación Editora Nacional, 2009.

León Galarza, Natalia Catalina. “¿Identidades post-clasistas? La protesta indígena de fin de siglo". En Etnicidad y poder en los países andinos, editado por Christian Büschges, Guillermo Bustos y Olaf Kaltmeier, 151-168. Quito: Universidad Andina Simón Bolívar / Universidad de Bielefeld / Corporación Editora Nacional, 2007.

Mancero Acosta, Mónica. Nobles y cholos: Raza, género y clase en Cuenca 1995-2005. Quito: FLACSO Ecuador, 2002.

Martínez, Luciano. "La nueva ruralidad en Ecuador: Siete tesis para el debate". Iconos, n. ${ }^{\circ} 8$ (1999): 12-19, doi: 10.17141 / iconos.8.1999.714.

Naranjo, Soledad. "Análisis del rol de las juntas parroquiales rurales el cantón Pelileo en los procesos de desarrollo local". Tesis de maestría. FLACSO Ecuador. 2010. http:/ / hdl.handle.net/10469/3035.

Nugent, Guillermo. "El laberinto de la choledad, años después". Quehacer, n. ${ }^{\circ} 170$ (2008): 86-95. https://es.scribd.com/document/73574364/El-Laberinto-deLa-Choledad.

Ortega, Karen. "Hegemonía comunal: Caso de estudio de la comuna de Toglla". Tesis de maestría. FLACSO Ecuador. 2015. http:/ / hdl.handle.net/10469/8626.

Ospina Peralta, Pablo, coordinador. En las fisuras del poder. Movimiento indígena, cambio social y gobiernos locales. Quito: Instituto de Estudios Ecuatorianos / CLACSO, 2006.

Pécout, Gilles. "Le local et le national, le centre et la périphérie". Le Mouvement Social 187 (1999): 3-9. http:/ / www.jstor.org/ stable/3779094. y Eduard J. Verger. "Cómo se escribe la historia de la politización rural. Reflexiones a partir del estudio del campo francés en el siglo XIX". Historia Social, n. 29 (1997): 89-110. http:/ / www.jstor.org/ stable/ 40340625.

Prieto, Mercedes. Liberalismo y temor. Imaginando los sujetos indígenas en el Ecuador postcolonial 1895-1950. Quito: FLACSO Ecuador / Abya-Yala, 2004.

Romero, Carmen. "Los desplazamientos de la raza, de una invención política y la materialidad de sus efectos". Política y Sociedad, n. ${ }^{\circ} 1$ (2003): 111-128. 
Sánchez Parga, José. "Los indígenas ante los poderes y gobiernos locales". En El Movimiento indigena ecuatoriano. La larga ruta de la comunidad al partido. Quito: Centro Andino de Acción Popular, 2007.

Santillana Ortiz, Alejandra. "Proceso organizativo y límites del proyecto político de Pachakutik". En En las fisuras del poder. Movimiento indígena, cambio social y gobiernos locales. Quito: Instituto de Estudios Ecuatorianos / CLACSO, 2006.

Sawyer, Mark. "'Race' to the Future: Racial Politics in Latin America 2015". Perspectives on Politics 3, n. ${ }^{\circ} 3$ (septiembre 2005): 561-564. http:/ / www.jstor.org/ stable/3689032.

Silva, Erika. Identidad nacional y poder. Quito: Abya-Yala, 2004.

Tilly, Charles. "From Movilization to Revolution". Working Paper. University of Michigan, 1977. deepblue.lib.umich.edu/bitstream/handle/2027.42/50931/156. pdf.

Van Cott, Donna Lee. Radical Democracy in the Andes. Nueva York: Cambridge University Press, 2008.

Wade, Peter. "Race in Latin America". En A Companion to Latin American Anthropology, editado por Deborah Poole, 177-192. Malden / Oxford: Blackwell Publishing, 2008.

Walsh, Catherine. "Raza, mestizaje y poder: las bases estructural-discursivas de la sociedad ecuatoriana". En Interculturalidad, Estado y sociedad: Luchas (de)coloniales de nuestra época, 25-40. Quito: Universidad Andina Simón Bolívar, Sede Ecuador / Abya-Yala, 2009. 


\section{SOLO LIBROS / reseñas}



PROCESOS

Revista ECUATORIANA de HISTORIA

Andrea Castagnola y Saúl López Noriega, editores. Judicial Politics in Mexico: The Supreme Court and the Transition to Democracy.

Nueva York: Routledge, 2016, 191 PP.

DOI: http: / / dx.doi.org/10.29078/rp.v0i46.651

El trabajo de Andrea Castagnola y Saúl López Noriega (2016) en Judicial Politics in Mexico: The Supreme Court and the Transition to Democracy (Políticas Judiciales en México: La Corte Suprema y la Transición a la Democracia) relanza la discusión sobre la transición democrática, desde nuevas ópticas. Atiende a un llamado que, a la luz que empiezan a arrojar las casi cuatro décadas desde que la tercera ola de democratización tocó tierra en América Latina a finales de los setenta, se hace para lograr una comprensión histórica del momento en sí y del despliegue de sus efectos.

La transición a la democracia ha sido objeto de intenso análisis en las Ciencias Sociales en América Latina desde principios de los ochenta. El modo de interpretar el punto de inflexión entre el autoritarismo y la democracia, sin embargo, a menudo ha sido objeto de al menos tres inconvenientes: una visión normativa y prescriptiva sobre el fenómeno de la transición -comprensible en su momento ante el inminente temor a una "regresión" autoritaria-; el uso de marcos conceptuales y disciplinares centrados de manera muy marcada en la Ciencia Política; y una aproximación centrada casi exclusivamente, desde lo institucional, en los actores del Ejecutivo y el Legislativo. Los tres inconvenientes impactaron directamente sobre la comprensión histórica del momento, por una parte, haciendo que se pierda la densidad de historización de una coyuntura crítica tan significativa que requiere intensos esfuerzos interdisciplinares, $y$, por otra parte, omitiendo el papel de otros actores, institucionales y no institucionales.

Ante esto, ¿cuál es el rol de la Corte Suprema en la transición democrática? La respuesta de Castagnola y López Noriega es dual. De un lado, la Corte Suprema en un proceso de democratización juega un rol más prominente en la garantía y protección de los derechos; y, de otro lado, ocupan un lugar más relevante en el juego para la resolución de disputas políticas. 
"Naturalmente, esto significa que los tribunales se enfrentan a diversas cuestiones relacionadas con la transición política, que incluyen cuestiones distributivas, de justicia administrativa y de resolución de disputas electorales. Parece que muchas nuevas democracias se encuentran en la posición de los Estados Unidos como lo señaló Tocqueville a principios del siglo XIX: casi no surge ningún conflicto político o social que no encuentre su camino hacia los tribunales (Ginsburg, 2016: 2)". Evidentemente, la situación de México y de América Latina debe atender elementos contextuales que varían ostensiblemente el modo en que las altas cortes han transitado por la vida institucional republicana, en muchos casos todavía con fuertes cuestionamientos respecto de su autonomía y efectividad.

El libro, compuesto de cinco capítulos más una introducción y unas conclusiones generales, se centra en la experiencia mexicana de transición democrática y acentúa las particularidades que el sistema de justicia en dicho país tiene, en gran medida a causa del período de dominio hegemónico del Partido Renovador Institucional (PRI) por algo más de setenta años durante el siglo pasado. Así, por ejemplo, es valioso notar cómo entre 1917 y 1994 solo cincuenta y cinco controversias constitucionales llegaron a la Corte Suprema, algo minúsculo si las comparamos con las más de quinientas enmiendas constitucionales realizadas a la Constitución de 1917. Además, entre 1933 y 1994 una regla informal en el esquema de poder era que los jueces debían estar afiliados al partido oficialista; adicionalmente, entre 1940 y 1994 hubo siempre al menos un oficial militar como juez; y, entre 1944 y 1994 la mayoría de Presidentes de turno nombró a más del 50\% de los jueces de la Suprema, puesto que casi un $40 \%$ de los mismos duraba en promedio menos de 5 años en el cargo, coincidiendo con los períodos presidenciales para mantener la prerrogativa informal de nombrar jueces afines para su período.

Así, en México se habla de una transición democrática tardía, gradual y muy particular. Es algo que se enfatiza en la obra, resaltando la transformación simultánea de los instrumentos e institucionalidad de la Corte Suprema junto con los cambios experimentados en los poderes políticos. Si bien se suele apuntar hacia la victoria de Vicente Fox con el Partido Acción Nacional (PAN) en 2000 como la derrota de la hegemonía del PRI, es preciso recordar que los cambios en el equilibrio del sistema político se empezaron a hacer visibles desde finales de los años de 1980: en 1989 perdió la mayoría absoluta de las dos terceras partes en el congreso y el monopolio de las gobernaciones. Asimismo, en 1997 el PRI perdió por primera vez la mayoría en la cámara baja en el congreso.

A la par, durante la década de 1990, la Corte Suprema adquirió roles más significativos con herramientas más poderosas para el control concreto y abstracto de constitucionalidad. Así, la centenaria acción de amparo pasó 
de tener efectos inter partes a tener efectos erga omnes. Con ello, la incidencia de la Corte Suprema se potenció, pudiendo llegar a tener efectos reales sobre las políticas públicas. De igual forma, cambios en el diseño institucional como la duración efectiva de períodos de quince años en el cargo para los jueces, reafirmaron una oportunidad sustantiva para la Corte Suprema de asentarse con firmeza en la división democrática de poderes dentro de un régimen constitucional pluralista. No obstante de ello, la obra de Castagnola y López Noriega presenta un balance respecto de qué tanto estos cambios, a priori positivos para la mayor y mejor garantía de derechos, así como para la cimentación de la Corte como poder contramayoritario, han logrado transformar una pesada trayectoria histórica de la justicia en México.

De esta forma, en el primer capítulo, Andreas Pozas-Loyo y Julio RáosFigueroa ofrecen un análisis sistemático del comportamiento de la Corte Suprema entre 1917 y 2013, juntando una perspectiva legal más tradicional con una lectura política más contemporánea. Lo hacen tomando como punto de partida las tres formas básicas reconocidas por la literatura politológica sobre cómo los jueces de las altas cortes toman sus decisiones: de acuerdo a la obediencia irrestricta a la Ley; de acuerdo a sus valores y principios; y de acuerdo a una adaptación al medio contextual. Lo importante es cómo los autores muestran que estas nociones necesariamente tienen una base histórica, toda vez que operan sobre preguntas tales como ¿por qué los jueces conciben su función del modo en que lo hacen?, y ¿cómo es que jueces específicos conciben su propia tarea? En otras palabras, hay una dimensión contextual variable explicada en el tiempo. Así, bien sea que adoptemos un modelo de voto mecánico, sincero o estratégico de los jueces, siempre debemos historizar las respuestas.

El segundo capítulo, de Pedro Salazar Ugarte, se fija en el período más reciente de la Corte, enfatizando el litigio estratégico y sus posibilidades de transformación social. Es decir, se piensa cómo los cambios experimentados en el diseño e instrumentos de la Corte pueden ponerse al servicio de la población como herramientas para avanzar en la agenda de los derechos humanos. Esto es por demás significativo en un país como México, donde los aparatos de defensa del Estado han sido autorizados para salir a las calles a combatir la delincuencia común y organizada. Salazar Ugarte muestra las considerables posibilidades que tiene la Corte para legitimarse socialmente desde un activismo judicial que avance derechos fundamentales, para lo cual también hace un llamado a la sociedad civil a activar mecanismos de litigio estratégico en temas relevantes como los derechos sexuales y reproductivos o el matrimonio igualitario. Por supuesto, la crítica a la Corte no está ausente, pues todavía, no obstante significativos avances, no muestra un rol absolutamente decidido. 
Los capítulos tres y cuatro son de autoría de Castagnola y López Noriega. En ellos ofrecen análisis empíricos de corte cuantitativo sobre muestras sumamente amplias de casos de la Corte. Esto refleja un empeño loable por investigar sistemáticamente a la Corte. A través de metodologías de la Ciencia Política neoinstitucionalista en su vertiente de elección racional, llegan a conclusiones contraintuitivas como que los jueces supremos en el actual período se muestran complacientes con el Ejecutivo, aun en circunstancias de gobierno dividido y de democracia pluralista. Es, sin duda, una de las partes más interesantes del libro, que invitan a mayores discusiones.

El último capítulo, de Francisca Pou Jiménez, se centra en el diseño institucional de la Corte, fijándose en restricciones externas e internas para el desempeño de este organismo, particularmente para que opere significativamente como un tribunal constitucional. Al respecto, cabe notar que México, a diferencia de la corriente prevaleciente en la región desde los años de 1990 no escindió una Corte Constitucional de la Corte Suprema, sino que esta última asumió más tareas. Pou Jiménez encuentra en la arquitectura de la Corte explicaciones para lo que denomina "borrosidad decisional", es decir, una patente incapacidad de mostrar líneas jurisprudenciales sólidas a lo largo del tiempo. Esto impacta en el sistema político y judicial elevando los grados de incertidumbre y difuminando el rol constitucional de la Corte, que podría y debería ser potenciado para la consolidación democrática.

Se trata de una obra valiosa para la transición democrática, así como para quienes estudian la división de poderes y el comportamiento de las altas cortes. Hay una invitación a seguir discutiendo estos temas, especialmente desde la historia, pues a menudo se cae en modelamientos abstractos que sirven analíticamente, pero que no dan cuenta de la casuística particular de causas judicializadas y de sus actores concretos. A su vez, la investigación sobre la Corte en México sirve de motivación para más investigaciones comparadas regionales y empíricas de cada país, desde la academia latinoamericana.

Adrián R. López Andrade Universidad Central del Ecuador 
Ahmed I. Deidán de la Torre. Pueblos y soberanía, continuidades

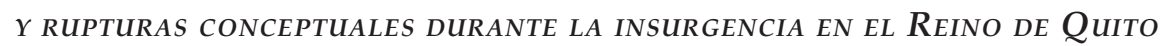
(1809-1813). Quito: Instituto Panamericano de Geografía e Historia / Instituto Ecuatoriano de Cultura Hispánica, 2016, 114 Pp.

\section{DOI: http: / / dx.doi.org/10.29078/ rp.v0i46.652}

A partir de las últimas décadas, la historiografía sobre las revoluciones atlánticas y las independencias hispanoamericanas se ha nutrido de abundantes debates configurados desde los enfoques de la nueva historia política y conceptual. El estudio de Ahmed I. Deidán de la Torre, titulado "Pueblos y soberanía, continuidades y rupturas conceptuales durante la insurgencia en el reino de Quito (1809-1813)", participa de estas líneas en tanto que traduce una visión reinterpretativa de la insurgencia quiteña fundamentada en la dinámica de los proyectos juntistas, así como el uso de los conceptos "soberanía" y "pueblos" durante dicha coyuntura.

Este trabajo, que constituye una exposición ampliada de su tesis de licenciatura realizada en la Universidad de California, fue reconocido por el Departamento de Historia de dicha entidad y publicado en 2016 con el respaldo del Instituto Panamericano de Geografía e Historia y el Instituto Ecuatoriano de Cultura Hispánica. Tal investigación se suma a una serie de escritos con los que circunda el campo de la economía decimonónica y la insurgencia americana.

El carácter de esta obra en particular transita desde una dimensión eminentemente descriptiva acerca del accionar quiteño en el marco de los fenómenos revolucionarios del mundo hispánico; hacia un terreno analítico sobre el lenguaje que reflejaba la cultura política de la época y que se manifestaba en la discursividad de manifiestos, correspondencias y documentación oficial, con base a los cuales Deidán de la Torre sustentó su trabajo. Tal enfoque evidencia una fuerte alineación dentro las propuestas historiográficas desarrolladas por Jaime E. Rodríguez, Mónica Quijada y Françoise Xavier Guerra.

Para iniciar, el autor despliega una retrospectiva sobre la crisis monárquica española a principios del siglo XIX. Su narración enfatiza en el accionar francés como piedra de toque para los procesos peninsulares, así como para la reacción hispánica consistente en la organización de juntas que intentaron, independientemente, sobrellevar el gobierno frente a la ausencia del rey. No obstante, con el establecimiento de la Junta Central en España, su transformación en Consejo de Regencia y el llamamiento a Cortes, Deidán de la Torre evidencia los debates que empezaron a suscitarse en torno a la 
monarquía, la representación de los pueblos, el derecho de los territorios ultramarinos y el desarrollo de una legislación moderna.

En un segundo acápite, extiende su tarea de contextualización hacia la Real Audiencia de Quito como parte del mundo hispánico. Para ello toma en cuenta la circulación teorías políticas relacionadas con la modernidad hispánica. Recurre a Rodríguez y Quijada para identificar el desarrollo temprano de discusiones sobre soberanía, pueblo y representación. ${ }^{1}$ Estas experiencias, según manifiesta, penetraron en todo Occidente y fomentaron la transición del mundo peninsular y americano hacia la modernidad política.

Dicha trayectoria muestra lo que, en términos de Rodríguez, significó la existencia de una cultura política compartida como soporte para revoluciones atlánticas ${ }^{2} \mathrm{y}$, de forma más local, para el accionar quiteño frente a la crisis monárquica. Hecho que Deidán de la Torre pone en evidencia al analizar la generación de espacios para el debate de tales ideas dada la situación intelectual que empezó a vivirse en Quito desde finales del siglo XVIII.

Cierra esta contextualización con una mirada hacia el ámbito jurisdiccional. Observa las reformas administrativas que supeditaron la Audiencia a los virreinatos del Perú y Nueva Granada, así como el estado socioeconómico de cada una de sus gobernaciones tras la aplicación de las políticas borbónicas que terminaron por beneficiar el crecimiento de Guayaquil o Cuenca, y socavar la preeminencia de Quito. De ahí que "la situación intelectual y socioeconómica [...] permite advertir y develar las motivaciones que potenciaron las acciones de ciertos quiteños para materializar cambios" dentro del orden establecido. ${ }^{3}$

Como tercer y cuarto punto, estudia el proceso insurgente desarrollado entre 1808 y 1812. De forma paralela a la minuciosa narración que hace sobre la Junta Suprema de Quito, canaliza un análisis enfocado en los lenguajes políticos usados durante dicha experiencia y, específicamente, en referencia a los conceptos "soberanía" y "pueblo/pueblos". Según lo manifestado por Javier Fernández Sebastián -quien sigue a su vez a Reihart Koselleck y su línea de historia conceptual-, el "lenguaje y la realidad son dos caras de la misma moneda". De forma que los conceptos, al ser una representación lingüística, entrañan un campo semántico donde se refleja la realidad y se recogen las experiencias históricas. ${ }^{4}$

1. Jaime E. Rodríguez, "Las Revoluciones Atlánticas: una reinterpretación”, Historia Mexicana, n. ${ }^{\circ} 252$ (abril-junio 2014): 1872-1873; Mónica Quijada, "Las dos tradiciones. Soberanía popular e imaginarios compartidos en el mundo hispánico en la época de las grandes revoluciones atlánticas". En Revolución, Independencia y las nuevas naciones de América, ed. por Jaime E. Rodríguez, 61-86 (Madrid: MAPFRE / Tavera, 2005), 78-84.

2. Rodríguez, "Las Revoluciones Atlánticas...", 1871-1882.

3. Ibíd., 36.

4. Javier Fernández Sebastián, "Hacia una historia de los conceptos políticos". En Dic- 
El estudio permite observar que, durante la coyuntura de la Junta Suprema, el entendimiento y la aplicación de la "soberanía" devino del pensamiento neoescolástico hispánico que la argüía como un poder dado de Dios al pueblo, y de aquel al rey. De esta forma, dicho concepto se convirtió en un elemento cardinal para sustentar acciones e ideas políticas emprendidas, como la retroversión del poder hacia el pueblo dada la ausencia de Fernando VII; el establecimiento de un gobierno conveniente que se concretó con la Junta; la equiparación política de Quito frente a los otros reinos peninsulares; o el reclamo por una representación propia ante las iniciativas gubernativas centrales.

Mientras, el concepto "pueblo/pueblos", como Deidán de la Torre lo explica, identificó una estructura conformada por cuerpos políticos que representaban a los vasallos. Esta visión corporativa, propia del Antiguo Régimen, se replicó en la Junta Suprema cuya conformación estuvo dada por representantes de corporaciones distinguidas que proporcionaron legitimidad al gobierno juntista. Entre tales actores colectivos, no obstante, se dejaba fuera a la plebe.

El cuarto punto aborda la segunda Junta quiteña. Su conformación en 1810, el apoyo que recibió por parte de los quiteños y la promulgación del "Pacto solemne", conformaron otras condiciones históricas frente a las cuales la noción de soberanía fue moldeándose. De esta etapa, el historiador resalta el carácter compartido y pluralista de la soberanía. A diferencia de la península donde empezó a relacionársela con término nación, quedando instaurado tal sentido moderno desde la Constitución liberal de Cádiz.

Estos acontecimientos también determinaron la movilidad semántica del concepto "pueblo", puesto que, según se analiza, la dinámica de la segunda junta permitió la incorporación de estratos bajos. Sin embargo, el naciente imaginario moderno y abstracto de "pueblo" como unión de individuos tampoco llegó a permear los imaginarios y lenguajes políticos locales.

Deidán de la Torre cierra su estudio comentando el fin del período fidelista dado el regreso de Fernando VII como un monarca absolutista. Situación que años más tarde abrió una lucha directa por las independencias americanas (p. 100). Como se ha mencionado, la mirada historiográfica sobre insurgencia americana y las experiencias juntistas es vasta. Sin embargo, la novedad de esta investigación radica en escudriñar aquellos acontecimientos desde una línea cercana a la historia conceptual. Precisamente, desde el título de la obra se ofrece ya una clara visión de dicha propuesta: indagar en

cionario político y social del mundo iberoamericano (Madrid: Fundación Carolina / Sociedad Estatal de Conmemoraciones Culturales / Centro de Estudios Políticos y Constitucionales, 2009), 27. 
la trayectoria de los conceptos "soberanía" y "pueblo" durante el período insurgente quiteño. En perspectiva, el trabajo de Deidán de la Torre cumple este cometido. Para lograrlo, podría objetársele que, en momentos, repliega los espacios de debate y análisis frente a la contextualización de los acontecimientos. Aspecto que carga a la obra de un carácter narrativo. No obstante, esta es la fórmula a la que el autor ha recurrido para clarificar la relación entre realidad-lenguaje, y que constituye en sí su derrotero.

A su vez, se observa que entre el tema abordado y las etiquetas de contenido no hay una relación manifiesta. Hecho que puede producirle al lector una impresión de discordancia, aunque no es más que un entrampamiento a nivel de forma.

En una cara opuesta, la demarcación del trabajo resulta muy pertinente dado que le permite al autor agotar el análisis dentro del enfoque temporal y espacial planteado. Hecho que deja abierto el camino para tomar la posta y pensar la temporalización de esos y otros conceptos de cara a las nuevas esferas de la modernidad política; o diversificar la mirada hacia lo que sucedía en otras gobernaciones más allá del proyecto juntista producido en Quito.

Adicionalmente, el aporte generado por este estudio a la historiografía ecuatoriana se produce en cuanto aterriza el enfoque reinterpretativo que desarrolla Jaime Rodríguez desde la nueva historia política o el emprendimiento liderado por Javier Fernández Sebastián en el campo de la historia conceptual, hacia un horizonte más concreto, dimensionando así los procesos locales en la palestra de aquellos novedosos debates historiográficos realizados durante los últimos años. 


\section{SOLO LIBROS / referencias}



PROCESOS

Revista Ecuatoriana de Historia

Academias y arte en Quito. 1848-1930. Quito: Casa de la Cultura Ecuatoriana, 2017, 122 pp.

Antología. Congreso Internacional de Historia. Modernidad en cuestión: Confluencias y divergencias entre América Latina y Europa. Siglos XIX y XX. Quito: Universidad Central del Ecuador / Editorial Universitaria, 2016, $523 \mathrm{pp}$.
Catálogo de la exposición organizada por la Casa de la Cultura Ecuatoriana y la Universidad Central del Ecuador en relación con la producción artística de las academias de Bellas Artes ecuatorianas, creadas dentro de las corrientes artísticas modernistas, en boga entre fines del siglo XIX y los primeros treinta años del XX. Estos espacios de creación y formación contribuyeron a la conformación del campo artístico ecuatoriano y a su posterior profesionalización. Los estudios compendiados se ocupan del afincamiento de la formación artísica profesional en la ciudad de Quito; el estudio de la obra del artista Joaquín Pinto; y de la consideración histórica de la creación de las Facultades de Artes en la Universidad Central del Ecuador. Adicionalmente, la publicación (profusamente ilustrada) entrega tres anexos documentales: el contrato suscrito entre el gobierno ecuatoriano y el artista Juan Manosalvas, para su perfeccionamiento artísitico en Roma y posterior retorno al Ecuador, como profesor de dibujo y pintura; un Cuadro de Informe Anual de la Academia de Bellas Artes; y el Reglamento para la Escuela de Bellas Artes, expedido por el Ministerio de Instrucción Pública.

El volumen reúne las ponencias del Congreso Internacional de Historia, organizado por la Universidad de Bolívar, la Universidad Central del Ecuador y AHILA, realizado del 26 al 28 de octubre de 2016. Los aportes se organizan a partir de los ejes temáticos del congreso: Relaciones epistemológicas de la Historia y los relatos: Entre Historia y Literatura; Historias de los ámbitos intelectuales; y Las identidades: convergencias, divergencias y solidaridades. 
Ayala Mora, Enrique. El bolivarianismo en el Ecuador. 2. ${ }^{\text {a }}$ ed. Quito: Universidad Andina Simón Bolívar, Sede Ecuador / Corporación Editora Nacional, 2017, 156 pp.

Ayala Mora, Enrique.

Lucha politica y origen de los partidos en Ecuador.

5. ${ }^{a}$ ed. Quito: Universidad Andina Simón Bolívar, Sede

Ecuador / Corporación Editora Nacional, 2017, 292 pp.

Borrero, Ana Luz, Juan

Carlos Brito, Catalina Carrasco et al. Claves de la historia de Cuenca. Cuenca: Cátedra / Universidad de Cuenca / Municipio de Cuenca, 2017, 375 pp.
Se trata de un compendio de artículos que proponen una interpretación de la vigencia política del bolivarianismo como ideología. El trabajo tiene dos partes, en la primera se presenta al lector una aproximación biográfica a Simón Bolívar y un acercamiento a su pensamiento político en el contexto de la Independencia. En la segunda parte se acomete el estudio del bolivarianismo en su desarrollo histórico dentro del Ecuador, la canonización y sacralización de la figura del Libertador y sus actuales circunstancias. En la segunda parte el ensayo avanza sobre las circunstancias más actuales del bolivarianismo, como sucede con el llamado "socialismo del siglo XXI".

El estudio trata sobre la formación de los partidos políticos en el Ecuador, su arco temporal comprende los primeras décacas del siglo XIX cuando se maceraron los procesos de Independencia hispanoamericana, hasta su útima década, en el momento del declive del radicalismo liberal encarnado en Eloy Alfaro. La obra se dedica a la comprensión de la formación de las estructuras políticas en el Ecuador republicano, así como a explicar la formación del Estado nacional a partir de sucesivos proyectos nacionales, encarnados en los grupos de poder que alcanzaron predominio. Se trata de un análisis inscrito dentro de las corrientes historiográficas marxistas, y que formó parte el movimiento de la "Nueva Historia del Ecuador", durante la década de los años 1980-1990.

Es un conjunto de estudios históricos dedicados a la comprensión histórica de Cuenca y su región, cuya autoría corresponde al grupo de investigadores de la Cátedra Abierta de Historia de Cuenca y su Región, y de los profesores y estudiantes de la Carrera de Historia y Geografía de la Universidad de Cuenca. Los aportes se han reunido de manera temática en siete secciones, dedicadas a la conformación del espacio regional en el contexto prehispánico, la conquista y la conformación urbana; las dimensiones sociales y culturales de la población cuencana y de sus visitantes, en relación con la cristalización del mestizaje, el desarrollo de la vida cotidiana, la religiosidad y la presencia en la región de personajes históricos relevantes; la fundación 
Cosamalón Aguilar, Jesús. El juego de las apariencias. La alquimia de los mestizajes y las jerarquías sociales en Lima, siglo XIX. Lima: Instituto de Estudios Peruanos, 2017, 430 pp.

Febres Cordero, Francisco. El Sabio ignorado. Bogotá: Penguin Random House, 2016, 175 pp. del primer hospital de la ciudad y la profesionalización del saber médico en el siglo XX, y la impronta de la explotación de plantas medicinales; las crisis políticas y la ebullición de los movimientos sociales durante el siglo XX; y los aspectos relacionados con la vida comercial y económica de la región.

La preocupación de esta obra gira en torno de la consolidación de la ciudadanía republicana en Lima, a partir del principio de igualdad ante la ley; los mecanismos socioculturales de la ciudadanía que permitieron la movilidad social, que fue posible a partir del funionamiento de dispositivos culturales como la moralidad, la decencia, la educación y la propiedad. El liberalismo, el racismo y la movilidad social de la época integraron una tríada social y política que dio forma a los procesos posteriores de discriminación económica y racial. La cuestión del "color de la piel" derivó en uno de los factores determinantes de la diferenciación social. A ella se articularon las formas económicas de establecer la movilidad social, situando en estratos superiores de poder adquisitivo a aquella población "más blanca" y en la inferior, con menor capacidad económica, distintas gradaciones de color de piel (grupos identificados como negros e indios). El argumento clave del estudio estriba en señalar que el ejercicio de determinadas actividades económicas permitía la percepción racial de cada grupo. Para el estudio, se indaga en fuentes documentales como censos y actas matrimoniales.

Biografía del historiador, aristócrata y político ecuatoriano Jacinto Jijón y Caamaño. El libro traza un recorrido por la época en la que vivió el personaje en sus dimensiones sociales y culturales, además de los pasajes políticos en los que intervino. También se exploran sus vínculos familiares así como sus legados. Se recompone también su faceta de historiador, científico y preocupado por la cultura ecuatoriana. Finalmente, la biografía se dedica a desentrañar los aspectos relacionados con el intelecto y carácter de Jijón. Todo ello a través de un ejercicio escriturario que combina el género periodístico con la narración ficcional. 
Gómez, David. De Velasco

Ibarra a Arroyo del Río. Reforma, revolución y contrarrevolución en la década de 1930 en Ecuador. Quito: FLACSO Ecuador, 2016, 222 pp.

Gomezjurado Zevallos, JAVIER. Historia de la muerte en Quito. Quito: Sociedad Funeraria Nacional, 2017, $340 \mathrm{pp}$.

LUCERO, IVÁN. La cartografía jesuita en la provincia de Quito (s. XVII-XVIII). Quito: Comisión de Historia de la Compañía de Jesús / Fundación Crisfe, 2015, 176 pp.

Noboa Bejarano, Gustavo y Parsival Castro Pita. Diego Noboa y Arteta. Un prócer de la independencia. Guayaquil: Municipalidad de Guayaquil, 2015, 129 pp.
El libro estudia el tipo de Estado conformado durante la década de 1930, momento en el que emergieron los partidos de masas, como parte de la crisis de la democracia liberal y el remezón del sistema representativo nacional. La emergencia de nuevas condiciones sociopolíticas se consideran desde la perspectiva de la emergencia social urbana (la política de masas) en relación con la organización popular y las mutaciones tanto en el sistema electoral, como en el ejercicio mismo de los rituales electivos.

Un recorrido por las prácticas funerarias en la ciduad de Quito. El trabajo realiza un periplo por las ritualidades aborígenes, las expresiones y actutudes sociales de las sociedades colonial y republicana ante la muerte, así como las manifestaciones mortuorias en la actualidad. Además, se realiza una historia de los cementarios considerados como espacios en los que prevalencen las jerarquías sociales y las formas de distinción de los quiteños. Se recorren estos escenarios al identificar los lugares de enterramiento de conquistadores, personas pertenecientes a la nobleza local y primeros pobladores hispanos. Se plantea también la consideración de las transiciones en cuanto a las formas de enterramiento, que van de los lugares aborígenes hasta las criptas en iglesias y conventos religiosos, hasta los cementerios.

Este libro presenta un conjunto de trabajos dedicados a la obra de los jesuitas en el contexto americano, en sus facetas evangelizadoras y adminitrativas. Los trabajos enfatizan en los aportes científicos de los religiosos en lo tocante, especialmente, a la construcción imaginaria de los territorios imperiales, por medio de la cartografía que prepararon como base de la colonización y la administración de las poblaciones indígenas en la presidencia de Quito.

Un estudio biográfico del político ecuatoriano que formó parte de la llamada Revolución marcista, que derrocó al general Juan José Flores. El trabajo revisa el quehacer familiar y personal del personaje, así como el desarrollo de sus roles como político. La biografía tiene una importante base de fuentes documentales de la época (prensa). El tabajo enfa- 
Pazos Barrera, Julio. Elogio de las cocinas tradicionales del Ecuador. Quito: Centro de Publicaciones PUCE, 2017, 430 pp.

Sarzosa, Gabriela. Emergencia de la sociología en el Ecuador a mediados del siglo $\mathrm{XX}$. Quito: FLACSO Ecuador, 2016, 170 pp. tiza, además, en el papel de Noboa en las luchas de Independencia, con el propósito de rescatar ese rol, poco considerado por la historiografía nacional, así como sobre sus tensiones con el general Urbina, otro de los líderes del marcismo.

Se trata de una aproximación etnográfica a los saberes culinarios del Ecuador, considerados como expresiones de una cosmovisión particular que mantiene específicas dimensiones sociales. La aproximación a la culinaria del país permite, además, comprender las diferencias regionales, las especificidades locales, así como la circulación de la cocina ecuatoriana en otros países, junto con la de sus ingredientes, como manifestación de las transiciones culturales ostensibles en las artes de la cocina, sus consumos culturales y los hábitos de comida considerados en sus dimensiones de prestigio.

Un estudio dedicado a comprender las circunstacias en las que se constituyó la sociología en la Universidad Central del Ecuador, desde la perspectiva de la conformación de un campo de saber especialicado. Entre los años 1955 y 1976 se operó una original brecha de carácter epistemológico entre una concepción del saber sociológico inscrito dentro de los linderos del conocimiento jurídico y una novedosa estructura matricial de corte marxista que aportó a la constitución de la sociología como saber crítico. Este original quiebre es interpretado como una ruptura entre dos "formas de verdad". Esta lectura es posible mediante la exposición de los objetos de conocimiento que se configuran en ambos momentos de construcción de la sociología, y a partir de la comprensión de sus propios enfoques y objetos de estudio. 

Eventos 



\section{Casa Abierta sobre buenas prácticas de archivos}

Los estudiantes de la Maestría en Archivística y Sistemas de Gestión Documental de la Universidad Andina Simón Bolívar, Sede Ecuador, realizaron una Casa Abierta como parte de las actividades realizadas para conmemorar el Día Internacional de los Archivos. El programa se llevó a cabo el 22 de junio y tuvo como propósito mostrar las buenas prácticas que se realizan en los lugares donde los estudiantes laboran, así como dar a conocer las posibilidades que ofrecen sus planes de tesis, los cuales se desarrollan en relación con las necesidades del país.

\section{"Rojo Estigma", teatralización en homenaje a los próceres}

El 2 de agosto el Centro Cultural Metropolitano y el Museo Alberto Mena Caamaño realizaron la representación teatralizada denominada "Rojo Estigma", como un homenaje a los próceres involucrados en la creación de la Primera Junta Soberana de Quito del 10 de agosto de 1809, quienes fueron asesinados el 2 de agosto de 1810. Durante ese día el público ingresó gratuitamente al Museo portando una rosa roja que luego fue depositada en la pileta del patio La Picota del mismo museo. Además, con el apoyo del Arzobispado, las campanas de las iglesias del Centro Histórico repicaron durante cinco minutos, a partir de las 13:30, hora en que inició la masacre del evento histórico mencionado. 


\section{Se presentó libro sobre González Suárez}

En el marco de la conmemoración de los 108 años de vida institucional de la Academia Nacional de Historia, el 17 de agosto se presentó el libro González Suárez: La patria y la academia, de Franklin Barriga López. La publicación corresponde al sexto volumen de la colección "Académicos de la Historia". Entre otros temas, el libro trata la relación entre religión y política; el origen de la Academia Nacional de Historia; la historia e historiografía del Ecuador; así como la controversia sobre el Estado laico mantenida entre González Suárez y José Peralta, entre otros ámbitos que el autor considera de interés para dar cuenta de la personalidad del obispo e historiador.

\section{Se exhibió el acta de fundación de Quito}

El Museo de la Ciudad y el Archivo Metropolitano de Historia presentaron la exhibición "Detrás del Papel", proyecto museográfico que exhibió el Libro Primero de Cabildos de Quito, archivo que contiene el acta de fundación de la ciudad. La exposición se inaguró el 8 de septiembre y estuvo abierta hasta el 29 de octubre de 2017. El proyecto fue parte de las actividades de conmemoración de la declaración de Quito como primer Patrimonio Cultural de la Humanidad. Además del acta mencionada, se puso a consideración del público varios documentos sobre el régimen político-administrativo español en el territorio quiteño, así como el proceso de conservación física de estos archivos documentales.

\section{Memoria y pensamiento de Jorge Eliécer Gaitán}

El 21 de septiembre se realizó la conferencia “Memoria y pensamiento de Jorge Eliécer Gaitán" en la Universidad Andina Simón Bolívar, Sede Ecuador. La charla fue dictada por Gloria Gaitán, quien explicó el pensamiento de su padre sobre la preocupación metódica en la cultura del pueblo para emprender cambios sociales o políticos, tema que vuelve a estar vigente debido a las negociaciones de paz que se realizan entre las guerrillas y el gobierno colombianos. Gloria Gaitán estudió Filosofía y Economía en la Universidad de los Andes, ha sido columnista en diversos medios, así 
como autora de varios libros; fue asesora del expresidente de Chile, Salvador Allende; y gestora del parque temático “Jorge Eliécer Gaitán”, centrado en la cultura participativa para la construcción de la democracia directa.

\section{Exposición y conferencias sobre Guayaquil como astillero del Mar del Sur}

La Dirección de Gestión Cultural de la Presidencia de la República presentó, entre el 2 de octubre y el 24 de noviembre, la exposición "Guayaquil, Astillero del Mar del Sur", la cual se exhibió en el Salón Protocolar del Centro Cultural Metropolitano. En el marco de la exposición se realizaron tres ponencias. La primera, realizada el 25 de octubre, se denominó "La amenaza de Brown y la incertidumbre en Guayaquil", estuvo a cargo de Sabrina Duque, quien explicó las reacciones ante la presencia extranjera de un grupo de revolucionarios porteños del virreinato del Río de la Plata, a inicios del siglo XIX. El 9 de noviembre se realizó la conferencia de Ernesto Salazar: "Naufragio del galeón Jesús María de la Limpia Concepción”, en referencia al siniestro ocurrido en la costa de Chanduy en el siglo XVII y los restos del tesoro de la "Capitana". El ciclo finalizó el 16 de noviembre con la charla "Reconstrucción de la Armada del Mar del Sur en los Astilleros guayaquileños", a cargo de Sebastián Donoso, quien se refirió a los antecedentes de la Armada entre 1680 y 1690, fechas en que se registraron varios ataques piratas en el puerto de Guayaquil.

\section{Alcaldía de Vinces emitió catálogos sobre la historia cacaotera}

El 4 de octubre se realizó la firma del acta de entrega-recepción de una colección de mil catálogos denominados “Un relato del cacao. Tempranas imágenes de Los Ríos" entre la Subsecretaría de Patrimonio y la Alcaldía de Vinces. Los catálogos se distribuyeron entre la población con el propósito de difundir el patrimonio documental integrado por fotografías que datan de hace más de un siglo y que se refieren a los inicios de la actividad cacaotera, considerada como la base de la transformación económica del país. El fondo fotográfico cuenta con imágenes capturadas mediante diversas técnicas como daguerrotipos, ambrotipos, ferrotipos, albúminas, fotografía iluminada y placas de cristal generados hasta la primera mitad del siglo XX. El estudio introductorio corresponde a Manuel Chiriboga Vega. 


\section{Aniversario de la muerte del Che se conmemoró con fotografía y cine}

Entre el 10 y el 13 de octubre la Casa de la Cultura Ecuatoriana Benjamín Carrión presentó una exposición fotográfica y un ciclo de cine para conmemorar los cincuenta años del asesinato de Ernesto "Che" Guevara. Las fotografías fueron tomadas por cronistas gráficos de la agencia cubana Prensa Latina y muestran al líder de la Revolución cubana ocupando diferentes cargos en el gobierno de ese país, así como representándolo en foros internacionales y visitas protocolares; mientras que el ciclo de cine mostró cintas que hacen referencia a su vida e ideales.

\section{Charla sobre los exiliados de la Guerra Civil Española en el Ecuador}

Como parte de los Coloquios de Investigación organizados por el Área de Historia de la Universidad Andina Simón Bolívar, Sede Ecuador, el 19 de octubre se realizó la charla "Exilio y arte en las dos orillas. Procesos de transculturación en Ecuador en los años 40 y 50", presentada por el profesor Antonio Canela Ruano. La ponencia versó sobre la influencia de los exiliados de la Guerra Civil Española y de la II Guerra Mundial en el arte ecuatoriano de esos años, cuyos cambios fueron fomentados por el retorno de ecuatorianos y por los migrantes e influidos por las exposiciones nacionales e internacionales, entre las que destacaron el Salón Mariano Aguilera y las Bienales Hispanoamericanas de Arte.

\section{Representación teatral "Las Banderas Rojas de Espejo"}

El 22 de octubre el Centro Cultural Metropolitano presentó en el Museo Alberto Mena Caamaño una representación teatral para conmemorar el 21 de octubre de 1794, cuando las cruces de los atrios de Santo Domingo, La Catedral y San Francisco aparecieron embanderadas, por iniciativa de Eugenio Espejo y otros quiteños como Mariano Villalobos y Juan Pío Montúfar. El evento histórico comenzó a conmemorarse en 2004 por iniciativa privada y ahora es acogido por el Municipio de Quito como uno de los actos de conmemoración de la Independencia. 


\section{Investigadores urbanos se reunieron en FLACSO}

El Seminario internacional "Desigualdades urbanas en América Latina y la Región Andina" se realizó entre el 25 y el 27 de octubre en la Facultad Latinoamericana de Ciencias Sociales (FLACSO), como parte de las actividades emprendidas por investigadores del área andina, en coordinación con instancias nacionales e internacionales. El propósito del encuentro fue promover el intercambio, el aprendizaje y la difusión de este tipo de indagaciones, dentro del Grupo de Trabajo sobre Desigualdades Urbanas del Consejo Latinoamericano de Ciencias Sociales (CLACSO), que da seguimiento a las resoluciones de Hábitat III en cuanto al papel del territorio y las ciudades en la generación y reproducción de desigualdades.

\section{Política Patrimonial y Museológica en Brasil: un panorama crítico}

El profesor Camilo de Mello Vasconcellos, coordinador del Programa de Posgrado Interunidades en Museología de la Universidad de São Paulo, presentó la conferencia “Política Patrimonial y Museología en Brasil: Un panorama crítico", organizada por Área de Historia de la Universidad Andina Simón Bolívar, Sede Ecuador, el 25 de octubre de 2017. Durante su intervención Vasconcelos presentó algunas reflexiones críticas respecto de la política patrimonial y museológica en Brasil, con especial énfasis en los cambios ocurridos a partir de la llamada "Era Lula" (2003-2010) y estableció conexiones entre la política oficial, la memoria y el discurso de la ciudadanía crítica y participativa en los años de referencia.

\section{Se realizó un Simposio de Historia organizado por el IPGH y la PUCE}

Entre el 7 y el 9 de noviembre se realizó el "V Simposio de Historia IPGH 2017. El pasado: Fundamentos de una identidad colectiva", el cual tuvo como ejes de trabajo la Historia Económica, Política, Cultural, Social, Patrimonio, Archivos y Bibliotecas especializadas, Antropología, Arqueología del Ecuador y América Latina. Tuvo como objetivos socializar investigaciones relacionados con los ejes de trabajo mencionados; analizar los desafíos de las 
Ciencias Sociales en el contexto de la realidad latinoamericana y mundial; y reconocer la importancia de la presencia de los historiadores en el ámbito laboral actual. El Simposio fue organizado por la Sección Nacional del Instituto Panamericano de Geografía e Historia y la Pontificia Universidad Católica del Ecuador, y estuvo dirigido a profesionales, investigadores, estudiantes y público en general.

\section{Muestra documental "Una mirada al mundo"}

El 10 de noviembre se inauguró “Una mirada al mundo, jefes de Estado en la correspondencia diplomática del Ecuador", muestra organizada por el Área de Historia de la Universidad Andina Simón Bolívar, Sede Ecuador, y el Archivo Histórico del Ministerio de Relaciones Exteriores y Movilidad Humana. Esta exposición documental puso a consideración del público las cartas autógrafas que enviaron al Ecuador diversos jefes de Estado, quienes incidieron en la historia regional y mundial. La muestra permitió difundir la documentación del Archivo Histórico de Cancillería entre público interesado y buscó animar a la investigación de las relaciones internacionales a través de la documentación diplomática.

\section{Conferencia sobre la reactivación de museos y complejos patrimoniales}

Margarita Reyes Suárez, jefa del Área del museología del Instituto Colombiano de Antropología e Historia (ICANH), presentó la charla "Reactivación de museos y complejos patrimoniales como espacios de construcción colectiva para la resolución de conflictos", el 22 de noviembre en la Universidad Andina Simón Bolívar, Sede Ecuador. La ponencia versó sobre las propuestas metodológicas con las cuales se busca reactivar el Museo Arqueológico de Tierradentro (Cauca) y el Fuerte de San Fernando (Caribe colombiano), donde se han tomado como elementos clave los conflictos de las comunidades cuyo espacio vital ha sido declarado patrimonio de la humanidad. 


\section{Conversatorio sobre el movimiento modernista}

La Academia Ecuatoriana de la Lengua y la Secretaría de Cultura de Quito presentaron el conversatorio "El modernismo ecuatoriano visto a cien años de su vigencia", el cual estuvo referido a sus precursores, así como al grupo central de la generación modernista y a sus prosistas. La actividad, llevada a cabo los días 23 y 24 de noviembre, tuvo como expositores a Julio Pazos, Álvaro Alemán, Marco Antonio Rodríguez y Carlos Freile Granizo, quienes pusieron en conocimiento del público el tiempo de vigencia del modernismo en el Ecuador, así como las repercusiones que tuvo en la cultura ecuatoriana, especialmente en el ámbito literario.

\section{Simposio sobre González Suárez, por el centenario de su fallecimiento}

La Red Metropolitana de Bibliotecas desarrolló un Simposio por el centenario del fallecimiento de Federico González Suárez. Durante los días miércoles 29 y jueves 30 de noviembre, varios académicos -especializados en diversas áreas del conocimiento- expusieron sobre las facetas del intelectual, obispo, historiador, y arqueólogo. Además del Simposio, la Red Metropolitana de Bibliotecas realizó una muestra de ediciones de González Suárez, así como una exposición de sus retratos. 



\section{Árbitros DE ESTE NÚMERo}

Procesos: revista ecuatoriana de historia agradece la participación de los evaluadores de este número.

Marc Becker, Truman State University (Estados Unidos).

Margarita Garrido, Universidad de los Andes y Externado de Colombia.

Ángel Emilio Hidalgo, Universidad de las Artes (Ecuador).

Fernando Hidalgo Nistri, investigador independiente.

Olaf Kaltmeier, Universidad de Bielefeld (Alemania).

Carolina Larco, Pontificia Universidad Católica del Ecuador.

Milton Luna, Pontificia Universidad Católica del Ecuador.

Federica Morelli, Universidad de Turín (Italia).

Adriana Pachecho, Pontificia Universidad Católica del Ecuador.

Trinidad Pérez, Universidad Andina Simón Bolivar, Sede Ecuador.

Inés del Pino, Pontificia Universidad Católica del Ecuador.

Guadalupe Soasti, Academia Nacional de Historia (Ecuador).

Rosemarie Terán, Universidad Andina Simón Bolivar, Sede Ecuador. 



\section{POLÍTICA EDITORIAL}

\section{ACERCA DE LA REVISTA}

Procesos: revista ecuatoriana de historia es una publicación académica semestral del Área de Historia de la Universidad Andina Simón Bolívar, Sede Ecuador. Se fundó en 1991 con el objetivo de fomentar la profesionalización de la disciplina histórica en Ecuador y América del Sur; y contribuir a la innovación de la investigación sobre el pasado de esta región. Aparece con el auspicio de la Corporación Editora Nacional.

Publica artículos de investigación inéditos, en idioma español, que son previamente evaluados por pares académicos anónimos, vinculados a centros de investigación de América Latina, Estados Unidos y Europa.

Cuenta con un Comité Editorial y un Comité Asesor Internacional integrados por académicos que laboran en universidades de Ecuador y otros países. El director de la revista preside ambos comités. El editor se encarga de coordinar el proceso de evaluación, y definir la secuencia y el contenido de los números. Cuenta con el concurso de un editor adjunto y un asistente editorial. La Corporación Editora Nacional se responsabiliza del diseño, armado e impresión.

La revista mantiene dos tipos de secciones, una de carácter permanente y otra ocasional. En la primera constan Estudios, Debates, Reseñas, Referencias y Eventos; mientras que en la segunda se incluyen Obituarios, Documentos, Traducciones, Aula Abierta, Diálogo Crítico y Entrevistas.

Las secciones arbitradas por los lectores anónimos son Estudios y Debates, que regularmente componen la mayor parte de cada número. Ambas contienen avances o resultados finales de investigaciones; balances historiográficos; discusiones temáticas, teórico-metodológicas, archivísticas e interdisciplinarias; así como intervenciones sobre debates específicos. La extensión de los artículos diferencia ambas secciones. En Estudios se incluyen contribuciones de hasta 11 mil palabras, mientras que en Debates el límite es de 6 mil. Las restantes secciones son evaluadas por el Editor y el Comité Editorial. 
Procesos ha sido aceptada en los siguientes índices y bases de datos internacionales:

- REDIB (Red Iberoamericana de Innovación y Conocimiento Científico)

- Dialnet (Sistema de alertas de la Universidad de la Rioja, España)

- ProQuest (Prisma, publicaciones y revistas sociales y humanísticas)

- Latindex (Sistema regional de información en línea para revistas científicas de América Latina, el Caribe, España y Portugal)

- Clase (Citas latinoamericanas en ciencias sociales y humanidades de la UNAM)

- HAPI (Hispanic American Periodical Index de la Universidad de California, Los Ángeles); Rebiun (Red de bibliotecas universitarias de España)

- Cibera (Catálogo del Instituto Iberoamericano de Berlín)

- Historical Abstracts (EBSCO)

- LatAm-Studies (Publicaciones académicas arbitradas sobre América Latina y el Caribe, Estados Unidos)

- $D O A J$ (Directory of Open Access Journals)

\section{Normas para autores, pares anónimos y editores}

\section{Sobre la presentación de artículos}

- Se reciben artículos de investigación, inéditos, en castellano, y cuyo contenido se inscribe en la descripción de las secciones Estudios y Debates, incluida en la sección "Acerca de la revista".

- Los textos presentados para publicación no deben haber sido remitidos a ninguna otra publicación, de manera simultánea. Por lo tanto, se asume que están libres de compromisos editoriales.

- No hay fechas específicas de recepción de trabajos para los números de tema libre, estos son procesados de acuerdo con el orden de llegada o según la invitación que se formule. En cambio, el cronograma de números monográficos se define entre el editor de Procesos y el coordinador del dossier.

- Los autores de artículos y reseñas deben enviar sus trabajos por correo electrónico a la dirección procesos@uasb.edu.ec. Además del artículo propuesto, se debe adjuntar un resumen en castellano en 100-150 palabras, un listado de ocho palabras clave, y los datos correspondientes al autor en 100-150 palabras, incluyendo su dirección electrónica, títulos académicos obtenidos, afiliación institucional, cargos actuales, tópicos de investigación, y últimas publicaciones.

- Los manuscritos presentados deben seguir las normas editoriales del Manual de Chicago Deusto (2013). Más adelante, en el apartado "Guía editorial", se incluyen ejemplos que ilustran estas pautas.

2. Obligaciones de los autores

- Al presentar un artículo, un autor declara que la autoría le pertenece íntegramente, y que respeta los derechos de propiedad intelectual de terceros. Si utiliza material ajeno (fotografías, cuadros, mapas, gráficos en general) debe incluir el crédito y la autorización legal respectiva. Al suscribir la autoría también declara 
que la investigación se condujo con honestidad y sin manipulación inapropiada de la evidencia.

- Los autores suscriben el "Documento de autorización de uso de derechos de propiedad intelectual", que faculta a la Universidad Andina Simón Bolívar, Sede Ecuador, la reproducción y comunicación pública de este material. La aceptación permite su publicación en papel y en forma electrónica. El autor mantiene los derechos intelectuales sobre su obra y se respetan los derechos de terceros.

\section{Acerca del proceso de evaluación}

- Todo artículo es evaluado por pares académicos anónimos. Por lo tanto, su autor se obliga a tomar en cuenta el dictamen final. Las modificaciones y/ o correcciones solicitadas son vinculantes con la publicación, y deben ser absueltas en el plazo indicado. Una vez recibido el trabajo modificado, se le informará al autor de su aceptación, así como del cronograma de publicación. La revista se reserva el derecho de realizar correcciones de estilo a los trabajos aceptados.

- Los pares anónimos externos examinan la calidad académica de los trabajos propuestos en un marco de libertad de expresión, diálogo crítico y adhesión a principios éticos.

- Sobre esta base, cada contribución es evaluada por dos lectores anónimos. Para el efecto, se emplea el "Formulario de evaluación" que se puede descargar del siguiente enlace: http://evaluacionpares.revistaprocesos.ec/. En caso de que aparezca una contradicción en el dictamen de los árbitros, se buscará un tercer evaluador dirimente. El Editor y el Comité Editorial se reservan la última palabra en cuanto a la publicación de un texto.

- No existe comunicación directa entre los evaluadores anónimos entre sí, ni entre estos y el autor del trabajo. La comunicación entre los actores está mediada por el Editor.

- Los árbitros tienen un plazo aproximado de cuatro semanas para efectuar la evaluación. Por su parte, los autores disponen de dos semanas para incorporar las observaciones.

- Las reseñas, solicitadas o recibidas, son evaluadas por el Editor y el Comité Editorial. Pueden versar sobre libros que hayan sido publicados en los últimos cuatro años.

\section{Responsabilidad de los editores}

- El Editor y el Comité Editorial tienen el encargo de llevar a la práctica las políticas editoriales de Procesos. Estas se orientan a asegurar la calidad del material publicable, fomentar la innovación de la investigación histórica, alentar el debate académico, preservar la libertad de expresión, aplicar el proceso de evaluación y publicación dentro de un marco de rigor y valores éticos, y afirmar, en lo posible, la integridad académica del material publicable.

- La coordinación de los procedimientos inherentes a la recepción, evaluación y aceptación de una contribución presentada a Procesos corresponde al Editor. La aceptación o rechazo de un artículo se realiza únicamente a partir del criterio de 
calidad e integridad académica. Al Editor también le corresponde la obligación de publicar enmiendas o rectificaciones.

- En caso de presentarse un conflicto de intereses, este será resuelto dentro del marco de las políticas editoriales, a cargo de una comisión de tres integrantes: uno del Comité Editorial y dos del Comité Asesor Internacional.

\section{GUÍA EDITORIAL}

- Los artículos propuestos para la sección Estudios deben observar el límite de 11 mil palabras; y para Debates un máximo de 6 mil, incluidas las notas de pie de página y la bibliografía. Se presentan a doble espacio, con márgenes de $2,5 \mathrm{~cm}$, en formato A4, letra Times New Roman, número 12, con sangrado en la primera línea de cada párrafo.

- Las citas textuales de más de cuatro renglones se colocan en un párrafo aparte, a espacio seguido, con margen reducido y sin sangrado.

- Las reseñas contienen hasta 1.500 palabras.

- Las notas de pie de página deben aparecer en números arábigos consecutivos, en letra 10, según las pautas de citación indicadas abajo.

- Al final de cada artículo se incluyen los repositorios consultados y la bibliografía empleada, con sangría francesa.

- Los artículos pueden incluir hasta dos niveles de subtítulos.

- En los casos de reproducción del segmento de una cita, o si a esta le faltan palabras y/o aparecen ilegibles, se recurre a la colocación de corchetes con puntos suspensivos [...]. También se emplean los corchetes para incluir letras o palabras que completen el sentido.

- Para referir otras fuentes debe emplearse la palabra "véase". Evitar los usos de "vid.", "ver" o "cf.".

- Las palabras en latín u otro idioma van en cursivas.

- La primera vez que se use una referencia que tenga abreviatura, debe constar el nombre completo, seguido de la sigla entre paréntesis. Luego solo se usará esta última.

- Todas las tablas, gráficas o ilustraciones deben contar con un pie de identificación, una numeración consecutiva y, en caso de remitirlas en archivo adjunto, incluir la referencia del lugar específico de inserción en el texto.

- Los archivos de fotografías o ilustraciones deben entregarse en formato digital adjunto de 300 DPI.

\section{Pautas de citación}

A partir del número 39, Procesos: revista ecuatoriana de historia sigue el sistema de "notas y bibliografía" de El Manual de Chicago Deusto (Bilbao: Universidad de Deusto, 2013). A continuación se presentan ejemplos sobre la forma de citación. Se emplean las siguientes abreviaturas: cita completa (N); nota abreviada (NA); y bibliografía (B). 
Libros

Un solo autor

(N) Jean-Paul Deler, Ecuador: del espacio al Estado nacional, 2. ${ }^{a}$ ed. revisada (Quito: Universidad Andina Simón Bolívar, Sede Ecuador / Instituto Francés de Estudios Andinos / Corporación Editora Nacional, 2007), 124-126.

(NA) Deler, Ecuador: del espacio..., 250.

(N) Inmediata. Ibíd., 114.

No usar las expresiones "íd.", ídem”, " art. cit.", "loc. cit.", "op. cit."

(B) Deler, Jean-Paul. Ecuador: del espacio al Estado nacional. 2. " ed. revisada. Quito: Universidad Andina Simón Bolívar, Sede Ecuador / Instituto Francés de Estudios Andinos / Corporación Editora Nacional, 2007.

Dos o tres autores

(N) Carlos Sempat Assadourian, Guillermo Beato y José Carlos Chiaramonte, Argentina: De la conquista a la independencia, vol. 2 (Buenos Aires: Paidós, 1992), 192-198.

(NA) Assadourian, Beato y Chiaramonte, Argentina: De la conquista..., 124.

(B) Assadourian, Carlos Sempat, Guillermo Beato y José Carlos Chiaramonte. Argentina: De la conquista a la independencia. Vol. 2. Buenos Aires: Paidós, 1992.

Cuatro o más autores

N) Magdalena Bertino et al., La economía del primer batllismo y los años veinte. Auge y crisis del modelo agroexportador (1911-1930), t. III de Historia Económica del Uruguay (Montevideo: Fin de Siglo / Instituto de Economía, Universidad de la República / Banco Central del Uruguay / Banco República, 2005), 62.

(B) Bertino, Magdalena, Reto Bertoni, Héctor Tajam y Jaime Yaffé. La economía del primer batllismo y los años veinte. Auge y crisis del modelo agroexportador (19111930). T. III de Historia Económica del Uruguay. Montevideo: Fin de Siglo / Instituto de Economía, Universidad de la República / Banco Central del Uruguay / Banco República, 2005.

Artículos

Capítulo de libro

(N) Alonso Valencia, "Importancia de Sucre en la historia de Colombia". En Sucre

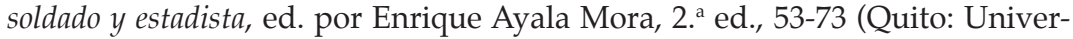
sidad Andina Simón Bolívar, Sede Ecuador / Corporación Editora Nacional, 2009), 164.

(NA) Valencia, "Importancia de Sucre...", 280.

(B) Valencia, Alonso. "Importancia de Sucre en la historia de Colombia”. En Sucre soldado y estadista, editado por Enrique Ayala Mora, 2. ${ }^{\text {a }}$ ed., 53-73. Quito: Universidad Andina Simón Bolívar, Sede Ecuador / Corporación Editora Nacional, 2009. 
Artículo de revista

(N) Daniel Gutiérrez Ardila, “El arrepentimiento de un revolucionario: José Manuel Restrepo en tiempos de la Reconquista (1816-1819)", Anuario Colombiano de Historia Social y de la Cultura 40, n. 2 (julio-diciembre 2013): 54-56.

(NA) Gutiérrez Ardila, "El arrepentimiento...", 74.

(B) Gutiérrez Ardila, Daniel. “El arrepentimiento de un revolucionario: José Manuel Restrepo en tiempos de la Reconquista (1816-1819)". Anuario Colombiano de Historia Social y de la Cultura 40, n. ${ }^{\circ}$ (julio-diciembre 2013): 49-76.

Publicaciones obtenidas de Internet (con referencia DOI)

(N) Nicolás Quiroga, "Blogs de historia: usos y posibilidades", Historia Crítica, n. ${ }^{\circ}$ 43 (ene.-abr. 2011): 73, doi:10.7440/ histcrit43.2011.05.

(B) Quiroga, Nicolás. "Blogs de historia: usos y posibilidades", Historia Crítica, n. ${ }^{\circ}$ 43 (ene.-abr. 2011): 62-80, doi:10.7440/ histcrit43.2011.05.

Publicaciones obtenidas de Internet (con referencia URL)

(N) Amy Taxin, "La participación de la mujer en la Independencia: el caso de Manuela Sáenz", Procesos: revista ecuatoriana de historia, n. ${ }^{\circ} 14$ (1999): 86, http:/ / revistaprocesos.ec/ojs/index.php/ojs/article/view/323/390.

(B) Taxin, Amy. "La participación de la mujer en la Independencia: el caso de Manuela Sáenz". http://revistaprocesos.ec/ojs/index.php/ojs/article/ view/323/390.

Artículos de prensa (con firma de autor)

(N) Luciano Andrade Marín, “El remiendo en el cuartel de los Limeños”, El Comercio, 1 de junio de 1964: 4.

(B) Andrade Marín, Luciano. "El remiendo en el cuartel de los Limeños". El Comercio. 1 de junio de 1964, 4 .

Artículos de prensa (sin firma de autor)

(N) "La cuestión muelle de Guayaquil", El Telégrafo, 28 de septiembre de 1920: 1.

(B) El Telégrafo. "La cuestión muelle de Guayaquil". 28 de septiembre de 1920: 1.

Tesis y documentos inéditos

(N) Rocío Rueda Novoa, “De esclavizados a comuneros en la cuenca aurífera del Río Santiago-Río Cayapas (Esmeraldas). Etnicidad negra en construcción en Ecuador siglos XVIII-XIX" (tesis de doctorado, Universidad Andina Simón Bolívar, Sede Ecuador, 2010), 30, http: / / repositorio.uasb.edu.ec/bitstream/10644/2815/1/ TD011-DH-Rueda-De\%20esclavizados.pdf.

(B) Rueda Novoa, Rocío. "De esclavizados a comuneros en la cuenca aurífera del Río Santiago-Río Cayapas (Esmeraldas). Etnicidad negra en construc- 
ción en Ecuador siglos XVIII-XIX". Tesis de doctorado. Universidad Andina Simón Bolívar, Sede Ecuador. 2010. http:/ / repositorio.uasb.edu.ec/bitstream/10644/2815/1/TD011-DH-Rueda-De\%20esclavizados.pdf.

\section{Entrevistas publicadas}

(N) François Hartog, entrevistado por Renán Silva, Historia Crítica, n. ${ }^{\circ} 48$ (sep.-dic. 2012): 209.

(B) Hartog, François. Entrevistado por Renán Silva. Historia Crítica, n. ${ }^{\circ} 8$ (sep.dic. 2012): 208-214.

Comunicaciones personales

(N) Frank Salomon (docente de la Universidad de Winsconsin, Madison), en conversación con el autor, junio de 2013.

Fuentes inéditas de archivo

(N) José Gabriel Pérez, "Informe al Mariscal Antonio José de Sucre, Yntendente del departamento de Quito", Guayaquil, 29 de julio de 1822, Archivo Nacional del Ecuador (ANE), fondo Presidencia de Quito, caja 595, ff. 28-33.

Archivos consultados

Deben presentarse al final del artículo, antes de la bibliografía consultada:

Archivo Nacional del Ecuador (ANE)

Fondo Presidencia de Quito

Fondo Notarial

Archivo Metropolitano de Historia de Quito (AMHQ)

Sección Secretaría Municipal

Sección Sindicatura o Procuraduría

\section{Contacto:}

Universidad Andina Simón Bolívar, Sede Ecuador

Toledo N22-80

código postal: 170413

e-mail: procesos@uasb.edu.ec

teléfono (593 2) 2993634

Quito, Ecuador 


\section{Editorial Policy}

\section{About the journal}

Procesos: revista ecuatoriana de historia is a biannual academic publication of the Department of History of the Universidad Andina Simón Bolívar, Sede Ecuador. It was established in 1991 with the objective of promoting the professionalization of the historical discipline in Ecuador and South America; and to contribute to the innovation concerning this region's past. It appears thanks to the sponsorship of the Corporación Editora Nacional.

It publishes unedited research articles, in Spanish, that are evaluated previously by anonymous academic peers, linked to centers of investigation throughout Latin America, the United States and Europe.

It has an Editorial Committee and an International Advisory Committee made up of intellectuals that work in Ecuadorian universities and in other countries. The director of the journal presides over both committees. The editor is in charge of coordinating the evaluation process and defining the sequence and content of the issues. It also has the support of an assistant editor and an editorial assistant. The Corporación Editora Nacional is responsable for the design, preparation and printing of each issue.

Each journal offers two types of sections, one permanent format and the other occasional. The permanent format exhibits Studies, Debates, Only Book/reviews, Only Books/references and Events; while the second occasional format includes Obituaries, Documents, Translations, Open Classroom, Critical Dialogue and Interviews.

The sections put together by anonymous readers are Studies and Debates that normally make up the majority of the content included in each issue. Both of these sections exhibit previews or final results of ongoing research projects; historiographic affairs; thematic discussions, methodological theory, catalogue archives and interdisciplinary matters; along with interventions concerning specific debates. The length of the articles distinguishes both sections. In Studies, for example, there are 11,000-word contributions, while Debates limits its contributions to 6,000 words. The remaining sections are evaluated by the Editor and Editorial Committee. 
Procesos has been accepted in the following indexes and international data bases:

- REDIB (Spanih American Network of Innovation and Scientific Knowledge)

- Dialnet (Alert system of Universidad de La Rioja, Spain)

- ProQuest (Prisma, publications and humanistic and social journals)

- Latindex (Regional system of on-line information for scientific journals for Latin America, the Carribbean area, Spain and Portugal)

- Clase (Latinamerican citations in social sciences and humanities of the UNAM)

- HAPI (Hispanic American Periodical Index of the University of California, Los Angeles)

- Rebiun (University library network of Spain)

- Cibera (Catalogue of the Iberoamerican Institute of Berlin)

- Historical Abstracts (EBSCO)

- LatAm-Studies (Compiled academic publications concerning Latin America, the Caribbean area and the United States).

- $D O A J$ (Directory of Open Access Journals)

\section{Norms/standards for authors, anonymous peers and editors}

\section{Concerning the presentation of articles}

- Procesos receives unedited research articles in Spanish whose content conforms to the guidelines listed in the Studies and Debates sections that are included in the section "About the journal".

- The texts presented for publication must have not been submitted to any other publication at the same time. Therefore, it is assumed that the articles are free of any kind of editorial compromise.

- There are not any specific dates for receiving articles for issues that have no designated theme, those are processed according to the order that they arrive or according to the invitation that is posed. On the other hand, the timetable of monographic issues is established by the editor of Procesos and the dossier coordinator.

- The authors of articles and summaries must send their articles by e-mail to the e-mail address: procesos@uasb.edu.ec. Besides the proposed article, each autor must include a summary in Spanish of 100-150 words, a list of eight key words, corresponding information about the autor with a limit between100-150 words, including the author's e-mail address, earned academic diplomas, institutional affiliation, current job positions, investigation topics and recent publications.

- The manuscripts presented must conform to the editorial norms of the Chicago Deusto Manual (2013). Later, in the heading "Editorial guide", there are examples that illustrate these guidelines.

\section{Author's obligations}

- At the moment of submitting the article, an autor declares that their work is their sole authorship and that they respect the rights of third-party intelectual property. If an autor uses material that belongs to other sources (photographs, paintings or pictures, maps, graphic representations in general) such autor should give credit and 
the respective legal authorization to include said source. At the moment of registering authorship, the autor also declares that their investigation was conducted with honesty and without innapropriate manipulation concerning the article's evidence.

- The authors fill out the "Authorization for use of intellectual property rights document" that the Universidad Andina Simón Bolívar, Sede Ecuador provides and the entity that reproduces and informs publicly this media. An autor can submit their publication on paper or digitally. The author maintains the intelectual rights of their work and the need to respect third-party rights.

\section{About the evaluation process}

- Every article is evaluated by anonymous academic peers. Therefore, each article's writer has to accept the final opinion of said anonymous evaluators. The solicited modifications and / or corrections are very important for each publication's success and each requested modification or correction need to be completed on time being that each issue adheres to strict deadline parameters. As soon as Procesos receives the modified work of an author, the journal's staff will inform the author of its acceptance status along with its publication schedule. The journal also has the right to make corrections concerning each article's style if an article has been approved for publication.

- The external anonymous peers examines the academic quality of each proposed work in a framework of characteristics like: freedom of expression, critical dialogue and adhesion to ethical principles.

- Concerning this aspect, each contribution is evaluated by two anonymous readers. To achieve this, the "evaluation form" can be downloaded from the following link: http: / / evaluacionpares.revistaprocesos.ec. In the case that a possible contradiction appears in the opinion of one or both of the evaluators, a third decisive evaluator could be included to render a possible solution to quell any author's doubts concerning the evaluation procedure's legitimacy. The Editor and the Editorial Committee have the final say concerning each proposed article's publication.

- There isn't any communication between either anonymous evaluator neither will the author be able to dialogue with either of the anonymous evaluators. The communication between each actor involved in the process is mediated by the Editor.

- Each evaluator has an approximate evaluation term of four weeks. In turn, authors have two weeks to make corrections or modifications concerning feedback given by the evaluators.

- Summaries, solicited or received, are evaluated by the Editor and the Editorial Committee. They can be about books that have been published during the last four years.

\section{Responsability of the Editors}

- The Editor and the Editorial Committee are in charge of putting in practice the editorial policies dictated by Procesos. Said policies are designed to assure the quality of publishable material, foster the innovation of historic investigation, encourage academic debate, preserve freedom of expression, apply the evalua- 
tion and publication process with rigorous and ethical values as its framework and confirm, when possible, the academic integrity of publishable material.

- The coordination of the procedures pertaining to the reception, evaluation and acceptacion of a presented contribution to Procesos is at the Editor's discretion. The acceptation or denial of an article depends exclusively on pertinent factors concerning quality and academic integrity. It also falls upon the Editor to publish corrections or rectifications.

- In the case of the occurrence of a conflict of interest, this will be resolved following guidelines established by editorial policy and carried out by a commision of three members: one from the Editorial Committee and two from the International Advisory Committee.

\section{EDITORIAL GUIDE}

- Proposed articles for the section Studies must observe the limit of 11,000 words; and for Debates a maximum of 6,000 words, including footnotes and the bibliography. It should be presented double-spaced, with $2.5 \mathrm{~cm}$ margins, in A4 format, using Times New Roman, number 12 letter size and the indention of the first line of each paragraph.

- Textual citations of more than four lines should be placed in a separate paragraph, with continuous spacing applied, margin reduced and no indention.

- Reviews have a limit of 1,500 words.

- Footnotes must appear in consecutive Arabic numbers and in letter size 10 according to the citation guidelines located below.

- At the end of each article each author should include consulted repositories and the employed bibliography using French indentation.

- Articles can have a maximum of two levels of subtitles.

- Concerning cases of the reproduction of segments of a citation or if said citation lacks words and / or they appear illegible, an author can resort to the application of suspension points located between square brackets [...]. Square brackets can also be employed to include letters or words to improve coherence or comprehension.

- To refer to other sources an author must employ the word "véase" (look at). Avoid the use of "vid" (abbreviation of vid or see), "ver" (see) or "cfr." or "cf." (compare or confer).

- Italics are to be utilized when using words in Latin or other languages.

- The first time that an author uses a reference that is abbreviated it must first have the complete name followed its abbreviation between parentheses. Any continued reference to said complete name can use just its abbreviated form between parentheses.

- All tables, diagrams or illustrations have an identification caption, consecutive numeration and, in the case of referring to them in an attached file, include the reference of the specific place of insertion in the text.

- Photographic or illustration files must be submitted by attaching them digitally with a 300 DPI format. 


\section{Citation guidelines}

Starting with issue 39, Procesos: revista ecuatoriana de historia follows the "notes and bibliography" system of El Manual de Chicago Deusto (Bilbao: University of Deusto, 2013). The following sections contain examples concerning citation formats. The following abbreviations are employed: complete citation (N); abbreviated note (NA); and bibliography (B).

Books

One Author

(N) Jean-Paul Deler, Ecuador: del espacio al Estado nacional, 2nd revised ed. (Quito: Universidad Andina Simón Bolívar, Sede Ecuador / Instituto Francés de Estudios Andinos / Corporación Editora Nacional, 2007), 124-126.

(NA) Deler, Ecuador: del espacio..., 250.

(N) Inmediata. Ibíd., 114.

Don't use expressions: "íd.", "ídem”, "art. cit.", "loc. cit.", “op. cit."

(B) Deler, Jean-Paul. Ecuador: del espacio al Estado nacional. 2nd revised ed. Quito: Universidad Andina Simón Bolívar, Sede Ecuador / Instituto Francés de Estudios Andinos / Corporación Editora Nacional, 2007.

Two or three authors

(N) Carlos Sempat Assadourian, Guillermo Beato y José Carlos Chiaramonte, Argentina: De la conquista a la independencia, vol. 2 (Buenos Aires: Paidós, 1992), 192-98.

(NA) Assadourian, Beato y Chiaramonte, Argentina: De la conquista..., 124.

(B) Assadourian, Carlos Sempat, Guillermo Beato y José Carlos Chiaramonte. Argentina: De la conquista a la independencia. Vol. 2. Buenos Aires: Paidós, 1992.

Four or more authors

(N) Magdalena Bertino et al., La economía del primer batllismo y los años veinte. Auge y crisis del modelo agroexportador (1911-1930), t. III de Historia Económica del Uruguay (Montevideo: Fin de Siglo / Instituto de Economía, Universidad de la República / Banco Central del Uruguay / Banco República, 2005), 62.

(B) Bertino, Magdalena, Reto Bertoni, Héctor Tajam y Jaime Yaffé. La economía del primer batllismo y los años veinte. Auge y crisis del modelo agroexportador (19111930). T. III de Historia Económica del Uruguay. Montevideo: Fin de Siglo / Instituto de Economía, Universidad de la República / Banco Central del Uruguay / Banco República, 2005.

Articles

Book chapter

(N) Alonso Valencia, "Importancia de Sucre en la historia de Colombia". In Sucre soldado y estadista, ed. by Enrique Ayala Mora, 2. ${ }^{a}$ ed., 53-73 (Quito: Universi- 
dad Andina Simón Bolívar, Sede Ecuador / Corporación Editora Nacional, 2009), 164.

(NA) Valencia, “Importancia de Sucre...", 280.

(B) Valencia, Alonso. "Importancia de Sucre en la historia de Colombia". In Sucre soldado y estadista, edited by Enrique Ayala Mora, 2. ${ }^{a}$ ed., 53-73. Quito: Universidad Andina Simón Bolívar, Sede Ecuador / Corporación Editora Nacional, 2009.

Journal Article

(N) Daniel Gutiérrez Ardila, “El arrepentimiento de un revolucionario: José Manuel Restrepo en tiempos de la Reconquista (1816-1819)", Anuario Colombiano de Historia Social y de la Cultura 40, n. ${ }^{\circ} 2$ (July-December 2013): 54-56.

(NA) Gutiérrez Ardila, "El arrepentimiento...", 74.

(B) Gutiérrez Ardila, Daniel. "El arrepentimiento de un revolucionario: José Manuel Restrepo en tiempos de la Reconquista (1816-1819)". Anuario Colombiano de Historia Social y de la Cultura 40, n. ${ }^{\circ} 2$ (July-December 2013): 49-76.

Publications obtained from Internet (with DOI reference)

(N) Nicolás Quiroga, "Blogs de historia: usos y posibilidades", Historia Crítica, n. ${ }^{\circ}$ 43 (Jan.-Apr. 2011): 73, doi:10.7440/ histcrit43.2011.05.

(B) Quiroga, Nicolás. "Blogs de historia: usos y posibilidades", Historia Crítica, n. ${ }^{\circ}$ 43 (Jan.-Apr. 2011): 62-80, doi:10.7440/ histcrit43.2011.05.

Publications obtained from Internet (with URL reference)

(N) Amy Taxin, “La participación de la mujer en la Independencia: el caso de Manuela Sáenz", Procesos: revista ecuatoriana de historia, n. ${ }^{\circ} 14$ (1999): 86, http: / / revistaprocesos.ec/ojs/index.php/ojs/article/view/323/390.

(B) Taxin, Amy. "La participación de la mujer en la Independencia: el caso de Manuela Sáenz". Procesos: revista ecuatoriana de historia, n. ${ }^{\circ} 14$ (1999): 85-113, http: / / revistaprocesos.ec/ojs/index.php/ojs/article/view/323/390.

Press articles (with author's signature)

(N) Luciano Andrade Marín, "El remiendo en el cuartel de los Limeños", El Comercio, 1st of June 1964: 4.

(B) Andrade Marín, Luciano. "El remiendo en el cuartel de los Limeños". El Comercio. June 1, 1964, 4.

Press articles (without author's signature)

(N) “La cuestión muelle de Guayaquil", El Telégrafo, September 28, 1920: 1.

(B) El Telégrafo. "La cuestión muelle de Guayaquil". September 28, 1920: 1. 


\section{Unedited documents and theses}

(N) Rocío Rueda Novoa, "De esclavizados a comuneros en la cuenca aurífera del Río Santiago - Río Cayapas (Esmeraldas). Etnicidad negra en construcción en Ecuador siglos XVIII- XIX" (doctoral dissertation, Universidad Andina Simón Bolívar, Sede Ecuador, 2010), 30, http:/ / repositorio.uasb.edu.ec/ bitstream/10644/2815/1/TD011-DH-Rueda-De\%20esclavizados.pdf.

(B) Rueda Novoa, Rocío. "De esclavizados a comuneros en la cuenca aurífera del Río Santiago - Río Cayapas (Esmeraldas). Etnicidad negra en construcción en Ecuador siglos XVIII- XIX". Doctoral dissertation. Universidad Andina Simón Bolívar, Sede Ecuador. 2010. http:/ / repositorio.uasb.edu.ec/bitstream/10644/2815/1/TD011-DH-Rueda-De\%20esclavizados.pdf.

Published interviews

(N) François Hartog, interviewed by Renán Silva, Historia Crítica, n. ${ }^{\circ} 8$ (Sep.-Dec. 2012): 209.

(B) Hartog, François. Interviewed by Renán Silva. Historia Crítica, n. ${ }^{\circ} 48$ (Sep.Dec. 2012): 208-214.

Personal contact

(N) Frank Salomon (faculty member of the University of Wisconsin, Madison), in a conversation with the author, June 2013.

\section{Unedited archive sources}

(N) José Gabriel Pérez, “Informe al Mariscal Antonio José de Sucre, Yntendente del departamento de Quito", Guayaquil, July 29, 1822, Archivo Nacional del Ecuador (ANE), Presidencia de Quito Fund, case 595, ff. 28-33.

\section{Consulted archives}

They must appear at the end of an article, before the consulted bibliography:

Archivo Nacional del Ecuador (ANE)

Fondo Presidencia de Quito

Fondo Notarial

Archivo Metropolitano de Historia de Quito (AMHQ)

Section Secretaría Municipal

Section Sindicatura or Procuraduría 


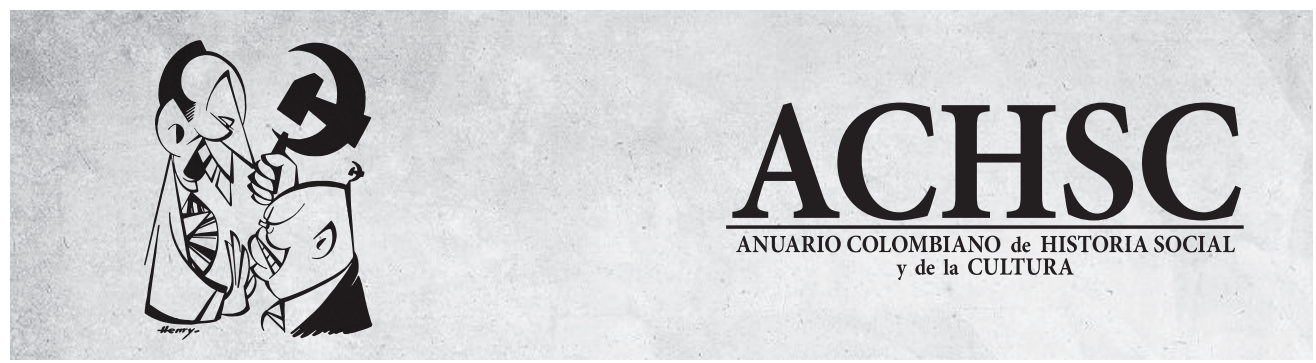

VOL. $44, \mathrm{~N}^{\circ}{ }^{2}$ JULIO-DICIEMBRE, 2017

ISSN: 0120-2456 (IMPRESO) · 2256-5647 (EN LÍNEA)

Editorial. Las izquierdas latinoamericanas desde la Revolución rusa hasta el presente

M A U R I C I O A R C H I L A

HORACIO TARC U S

A R T Í C U L O S / D O S S I E R

Radicalizar la reforma universitaria. La fracción revolucionaria del movimiento estudiantil argentino, 1918-1922

NAT A L I A B U S T E L O

L U C A S D M ÍNG UEZ RUB IO

La Comintern, el PCM y el "caso Sandino": historia de una alianza fracasada, 1927-1930

VÍCTOR J E I FETS

L A Z A R J E I F E T S

Izquierdas, género e industria textil argentina. Los partidos comunista y

socialista ante las demandas de las trabajadoras, 1936-1946

VER Ó N I C A N O RA N D O

Historia del maoísmo en América Latina: entre la lucha armada y servir al pueblo

M I GUEL ÁNGEL URREG O

El campo es leña seca lista para arder. La Liga Marxista Leninista de Colombia, 1971-1982

FRA N K MOLANO CAMARGO

Lucha por el poder y representación política del campesinado: los exguerrilleros liberales del sur del Tolima, 1957-1960 DAVID FELIPE PE ÑA VALENZUELA

Historia de la interacción político-militar entre guerrillas colombianas, 1964-2015

LUIS MIGUEL BUITRAGO ROA

M I G U E L ESTEBA N S UÁ REZ GUTIÉRREZ

Versos de amores que matan los odios malditos del yanqui opresor: música insurgente y discurso político de las FARC-EP GA B RIEL DAVID SAMACÁ

D E B A T E S

La izquierda colombiana: un pasado paradójico, ¿un futuro promisorio?

CHARLES B ERGQU IS T

A R T Í C U L O S / T E M A L I B R E

Enseñanza religiosa y poder clerical. Estados Unidos de Colombia, 1863-1886

LEONARDO TOVAR BERNAL

Visiones norteamericanas de la Iglesia católica progresista en Brasil, 1964-1972: de la sospecha a la colaboración

S I G IF RED O ROMERO

R E S E N N A S

\section{CONTACTO}

Cra. 30 n. ${ }^{\circ}$ 45-03, Departamento de Historia, edificio Manuel Ancízar, oficina 3064, Bogotá, Colombia

Tel.: (57-1) 3165ooo, exts. 16486, 16477

anuhisto_fchbog@unal.edu.co / anuhisto@gmail.com

W W W. A N UA RIODEHIS TORIA. UNA L. EDU. C O 


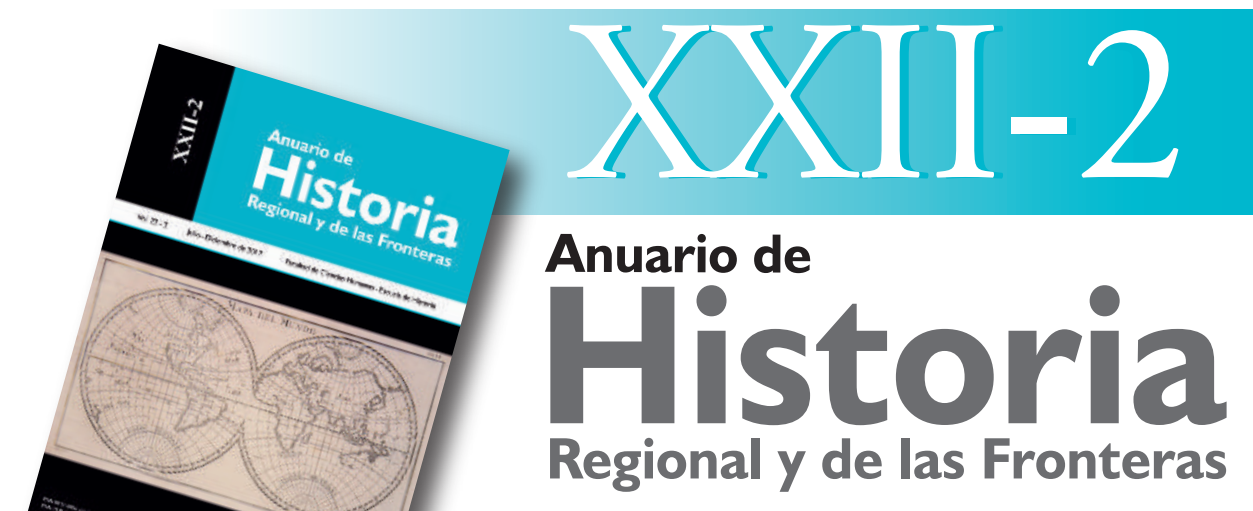

Dosier: Cultura, globalización, territorio e identidades en Iberoamérica

Tabla de Contenido

Editorial

Marco Oliveira Borges: A importância estratégica do conhecimento do território na formação de um sistema defensivo: o caso de Sintra (Portugal) durante o período islâmico

Revista de la Escuela de Historia de la Universidad Industrial de Santander

Anuario de Historia Regional y de las Fronteras Escuela de Historia Edificio de Humanidades piso 3 cra 27 call 9 tel 6451639

email: ahistoriauis@gmail.comanuariohistoria@uis.edu.co Universidad Industrial de Santander
Rita de Cássia Guimaräes Melo: A experiência dos representantes do sistema judiciário e suas relações com os habitantes das comarcas na região Norte de Goiás (1870-1900)

Raquel Valeria Bressan: Las disputas por los territorios en los albores del Estado nación: la frontera oriental de Corrientes durante la segunda mitad del siglo XIX

Marco M. S. Arraes: Para além das fronteiras nacionais: imagens do americanismo como modelo de vida no ocidente. O Brasil como estudo de caso (1945-1964)

Álvaro Acevedo Tarazona y Andrés Correa Lugos: La universidad latinoamericana frente a la globalización. Continuidades e inflexiones de un mismo proceso (1968 y 201I)

\section{Otros artículos}

Joan Manuel Largo Vargas: Los espacios para la acción. Intersticios y tramas en la construcción del relato en la Microhistoria y el Marxismo Británico

Sofía Norma Brizuela Molina: ¿Cómo se funda un convento? Algunas consideraciones en torno al surgimiento de la vida monástica femenina en Santa Fe de Bogotá (1578-1645)

José Abelardo Díaz Jaramillo: La huelga del Colegio del Rosario y la Reforma Universitaria en Colombia (1930)

Sergio Armando Cáceres Mateus: La Acción Católica en la organización y puesta en marcha del Segundo Congreso Nacional Mariano de Colombia (1939-1946)

\section{Transcripciones}

Hugo José Castro Valdebenito. "Motín en Aconcagua. Fuentes para una Historia Regional. Oficios enviados por el intendente Juan F. Fuenzalida al ministro del Interior Antonio Varas, respecto de los sucesos del 14 de octubre de $185 \mid "$.

Leonardo Fabián García Rincón. "Interrogatorios de las visitas de 1602, 1623, I64I y 1657 a la Provincia de Pamplona".

\section{Reseñas}

Andrés Camilo Suarez Garzón. Roger Pita Pico. La manumisión de esclavos en el proceso de independencia de Colombia: realidades, promesas y desilusiones. Bogotá: Editorial Kimpres Ltda., 2014. 237 páginas.

Luciana Mercedes Linares. Irene D. Molinari. Vencer el miedo. Historia social de la lepra en Argentina. Rosario: Prohistoria ediciones, 2016. 28I páginas.

Paola Ruiz. Juan Gonzalo Zapata Giraldo. Reforma radical en el estado de Santander, 1850-1885. Bogotá: Universidad del Rosario, 2015. 342 páginas.

Índice acumulativo

Evaluadores de este número

Normas de publicación del Anuario de Historia Regional y de las Fronteras 


\section{Colonial Latin American Historical Review (CLAHR)

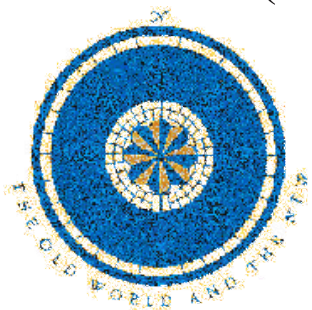 \\ Énfasis: ÉPOCA COLONIAL EN AMÉRICA LUSO-HISPANA}

\section{SOLICITAMOS SU PARTICIPACIÓN CON}

estudios originales basados en fuentes de archivo, máx. 25-30 págs. con notas al pie de página. Envíe un archivo creado en Microsoft Word por correo electrónico

$$
\text { en inglés o español }
$$

\section{Órden de suscripción:}

Nombre:

Dirección:

Teléfono:

Correo Electrónico:

$\square$ Individual \$40 $\square$ Institución \$50 $\square$ Estudiante \$35 $\square$ Un ejemplar \$14

(Para subscripciones agregue $\$ 15$ por costo de envío en zonas de los Estados Unidos, \$25 en áreas fuera de los Estados Unidos. Para un sólo ejemplar agregue \$5 por tarifa postal fija.)

Cheque o giro a nombre de: Spanish Colonial Research Center

Envíe esta forma con el pago apropiado al Dr. Joseph P. Sánchez, editor:

\section{Correo postal:}

Spanish Colonial Research Center, NPS

MSC05 3020

1 University of New Mexico

Albuquerque NM 87131-0001 USA

\section{Dirección física/envíos de paquetería:}

Spanish Colonial Research Center, NPS Zimmerman Library

1 University of New Mexico

Albuquerque NM 87131-0001 USA

Teléfono (505)277-1370 / Fax (505)277-4603 


\section{ECUADOR DEBATE}

\section{$\mathbf{N}^{\mathbf{0}} \mathbf{1 0 0}$}

Centro Andino de Acción Popular

\section{COYUNTURA}

Situación de la Economía ecuatoriana y desafíos del nuevo Gobierno

Conflictividad socio-política: Noviembre 2016-Febrero 2017

\section{TEMA CENTRAL}

Representaciones de la cultura popular en la caricatura política ecuatoriana a mediados del siglo $\mathrm{XX}$

Prácticas artísticas contemporáneas y cultura popular

La irrupción del 'otro'. Economías audiovisuales populares en contextos poscoloniales

El Boom de la tecnocumbia en el Ecuador

El Divino Niño en Quito. Transferencias culturales, apropiaciones religiosas y disputas sociales

\section{DEBATE AGRARIO-RURAL}

Vulnerabilidad de la agricultura familiar y de los territorios rurales en los Andes ecuatorianos. Un análisis desde la provincia del Azuay

\section{ANALISIS}

Campo del poder en Ecuador y su reconfiguración por el Gobierno de Alianza País El macho sabio. Racismo y sexismo en el discurso sabatino de Rafael Correa

\section{RESEÑAS}

Crónica de los Andes. Memorias del "otro"

Los neo-indios. Una religión del tercer milenio

El río. Exploraciones y descubrimientos en la selva amazónica

Suscripciones: Anual 3 números: US \$ 51 - Ecuador: \$ 21

Ejemplar suelto: Exterior US \$ 17,00 - Ecuador: \$ 7,00

Redacción: Diego Martín de Utreras N28-43 y Selva Alegre - Telef. 2522-763

Apartado aéreo 17-15-173 B Quito-Ecuador 

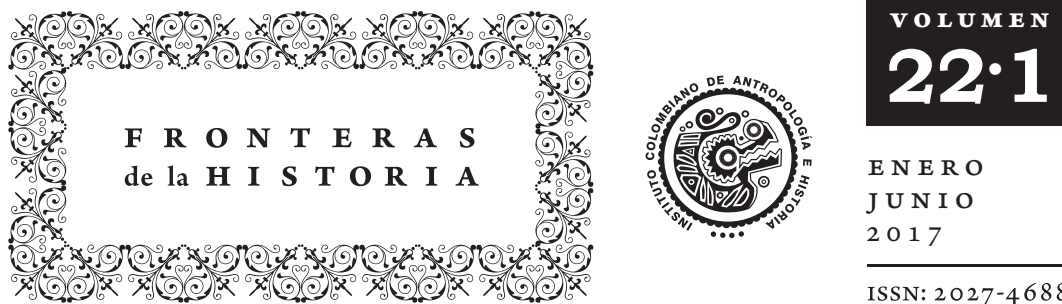

E N E R O

J U N I O

2017

ISSN: $2027-4688$

R E V I S T A D E H I S T O R I A C O L O N I A L L A T I N O A M E R I C A N A

\section{En este volumen:}

- Bárbara Aramendi: El distrito de la Puna y su primer subdelegado.

Intendencia de Salta del Tucumán, 1784-1795

- C. RENÉ DE LEÓN MEZA: Reflexiones en torno al origen tardío de la producción del tequila en el pueblo de Tequila

- JOSEFina SChenke: Sobre el uso del término mestizo en la historiografía de la historia de las imágenes en Chile. Una propuesta crítica

- ROdolfo AguirRe SAlvador: Problemáticas parroquiales y escasez de ayudantes de cura en el arzobispado de México a fines del siglo xviII

- MARí A CRISTINA NAVARRETE: Una noche de luces y festejo en Cartagena de Indias, 1690

- José JoAQuín PINTO Bernal: Fiscalidad en Caracas, 1750-1845. Del reformismo borbónico al liberalismo de mediados de siglo

- CARMEN RUigómez gómez: Los efectos de la creación del Virreinato de Nueva Granada en la Real Hacienda de Quito (1718-1721)

\section{CONTACTO:}

fronterasdelahistoria@gmail.com

VISITE NUESTRA PÁGINA WEB: www.icanh.gov.co/Publicaciones

VISÍTENOS EN LAS REDES SOCIALES: www.facebook.com/FronterasDeLaHistoria www.twitter.com/FrontHistoria
PUNTOS DE VENTA:

- Instituto Colombiano de Antropología e Historia (ICANH) Librería: Calle 12 n. ${ }^{\circ} 2$ - 41 Bogotá, Colombia Teléfono: (571) 4440544 ext. 118

Principales librerías colombianas 


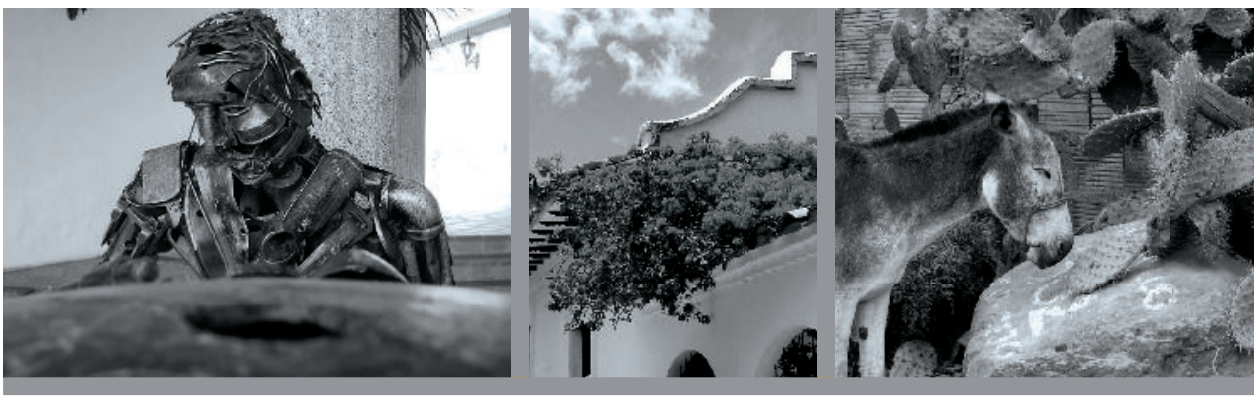

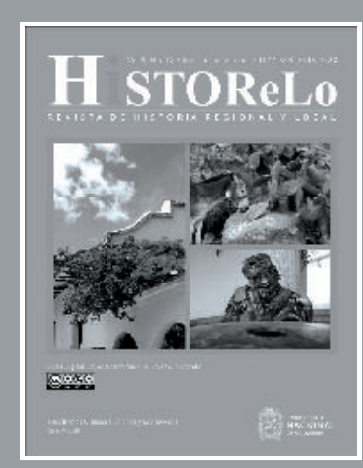

ISSN: 2145-132X

Vol 9, No. 18

Julio - diciembre de 2017

HiSTOReLO.

Revista de Historia Regional y Local

Facultad de Ciencias

Humanas y Económicas

Indexada en: Scopus, Clase, Scielo, Publindex (Categoria A2) Latindex, Historial Abstracts, Latam-Studies, Fuente Académica - Ebsco, Doai, Dialnet, Drii, SocINDEX, entre otras.

Correo electrónico

historelo@unal.edu.co

Teléfono: +57 (4) 4309888

Ext. 46234 . Fax: +57 (4) 2604451

Página oficial - Portal de Revistas UN http://www.revistas.unal.edu.co/ index.php/historelo/index

\section{ARTÍCULOS}

De caciques hereditarios a alcaldes y mandones electos. Legitimidad del poder local en los pueblos de indios constituidos con una base étnica, en el valle del río Cauca (1675-1800)

Héctor Manuel Cuevas Arenas

"Aunque rústicos, no les faltaba el conocimiento de la razón": Justicia y sociedad campesina en el sitio de Chinú. Nuevo Reino de Granada, 1798-1813

Jorge Conde Calderón

Vecinos, vasallos y defensores del Rey, condiciones necesarias para el ciudadano en la Provincia de Pasto, 1809-1823

Ángela Rocío Mora Caicedo

\section{William Bollaert y sus} descripciones geográficas, cartográficas y antropológicas sobre la provincia de Tarapacá en la etapa inicial de la formación republicana del Perú, 1827-1854

Luis Castro Castro

Carolina Figueroa Cerna

Paglo Guerrero Oñate

Benjamín Silva Torrealba
Transformaciones de la masculinidad de los tranviarios de Guadalajara durante el Porfiriato Cristina Alvizo Carranza

Líderes locales, liberalismo y autonomía en la Revolución Mexicana. Pahuatlán, Puebla, 1911-1914

Óscar Fernando López Meraz Diana Villegas Loeza

Espacios ausentes. Conventillo, rancho y periferia: emergentes urbanos de la segregación. Rosario, Argentina (1900-1935) Cecilia María Pascual

El cine que corrompe o exalta: prácticas y discursos de la censura cinematográfica. El caso de Cali, Colombia, 1945-1955

María Fernanda Arias Osorio

Memoria, arte y duelo: el caso del Salón del Nunca Más de Granada (Antioquia, Colombia)

Elkin Rubiano Pinilla

\section{REVISIÓN \\ RESEÑAS \\ ENTREVISTAS}




\section{HISTORIA 패메 CARIBE 30}

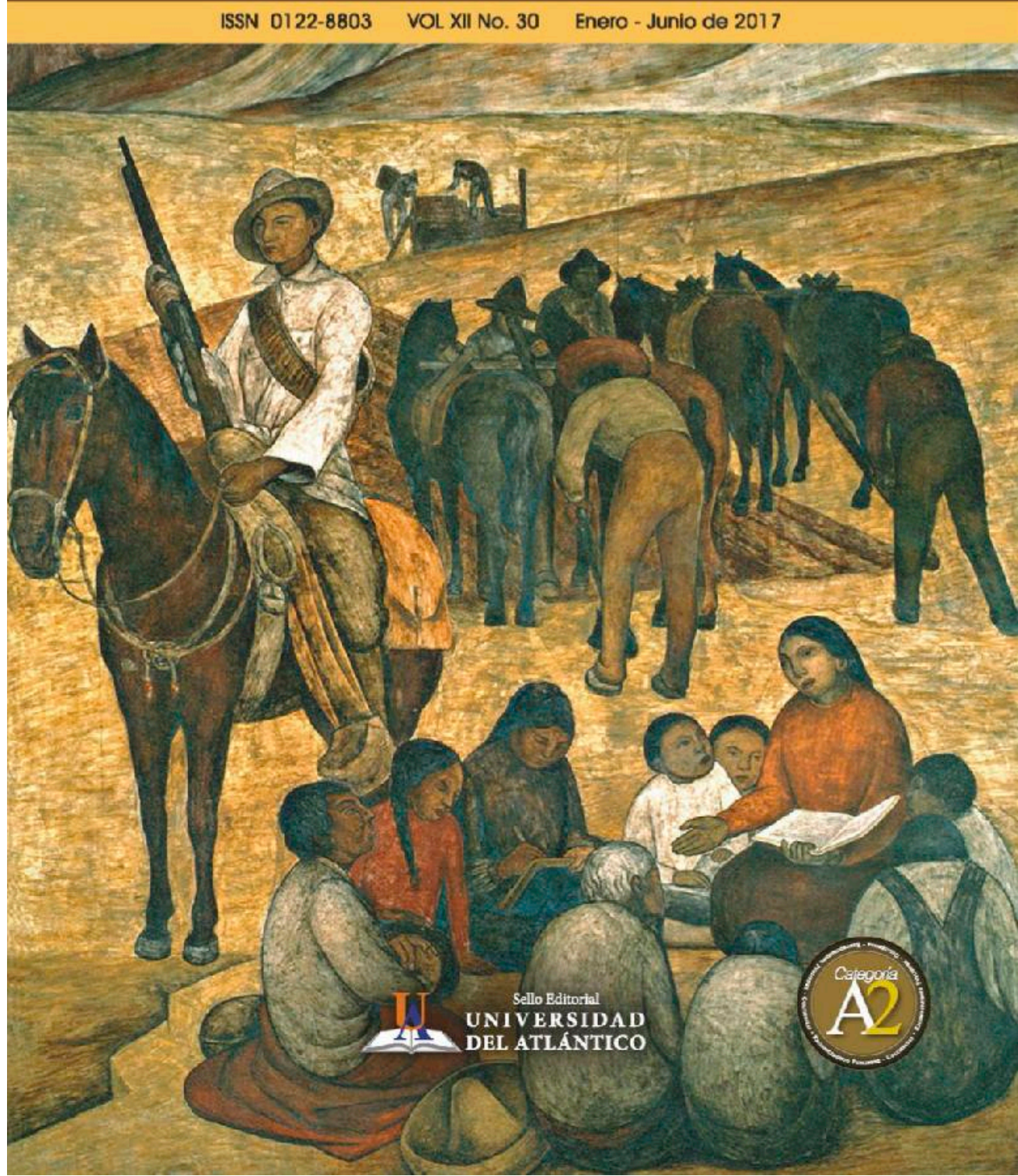




\section{HISTORIA}

Universidad de los Andes · Facultad de Ciencias Sociales

Departamento de Historia

Bogotá, Colombia

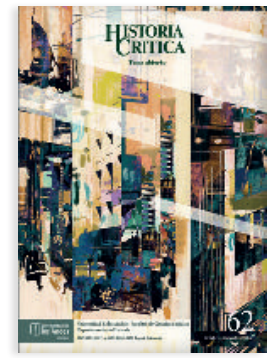

Tema abierto

Octubre-diciembre 2016

Precio $\$ 30.000$ (

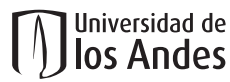

colombia

Dirección: Cra. 1 N$^{\circ} 18$ A - 12, Of. G-421, Bogotá, Colombia, Teleléfono: +57 (1) 3324506 +57 (1) 3394949 ext. 2525-3716

Correo electrónico: hcritica@uniandes.edu.co Sitio web: http://historiacritica.uniandes.edu.co

Tarifa en Colombia Ejemplar: $\$ 30.000$

Librería Uniandes y librerías nacionales

Para suscripción nacional e internacional: http://libreria.uniandes.edu.co/

\section{Carta a los lectores $\cdot 9-10$}

\section{Artículos tema abierto}

¿En defensa de la Doctrina Monroe? Los desencuentros en América Latina entre España y Estados Unidos (1880-1890) · 13-33

Andrés Sánchez Padilla, Investigador independiente, España

Trabajo y vejez en el período prejubilatorio. Hipótesis y análisis de fuentes históricas sobre el caso argentino, 1850-1950 ·35-55

Hernán Otero, Instituto de Geografía, Historia y Ciencias Sociales, CONICET, Argentina

La militarización del Estado durante la última dictadura militar argentina.

Un estudio de los gabinetes del Poder Ejecutivo Nacional entre 1976 y 1983·57-75 Paula Canelo, Universidad Nacional de San Martín/CONICET, Argentina

Iglesia liberadora, rearticulación de la política y protesta social en Chile (1973-1989) · 77-96

Viviana Bravo Vargas, Universidad Nacional Autónoma de México

Los comienzos de la terapia ocupacional en Estados Unidos: una perspectiva feminista desde los estudios de Ciencia, Tecnología y Género (siglo XIX y XX). 97-117

Rodolfo Morrison Jara, Universidad de Chile/Universidad Bernardo O’Higgins, Chile

Neoliberalismo y crisis económica: políticas estatales, mercado y agricultores en Chile, 1973-1985 - 119-139

Fabián Almonacid Zapata, Universidad Austral de Chile

\section{Espacio estudiantil}

De lo artesanal a lo industrial. La consolidación de la industria de medicamentos en Cali (Colombia, 1876-1944) ·143-163

María Fernanda Erazo Obando, Universidad de Buenos Aires, Argentina

\section{Reseñas}

Womack, John. El trabajo en la Cervecería Moctezuma, 1908. Ciudad de México/Xalapa: El Colegio de México/Fideicomiso Historia de las Américas/ H. Congreso del Estado de Veracruz, 2012 · 166-168

Eder Antonio de Jesús Gallegos Ruiz, Universidad Pablo de Olavide, de Sevilla, España

Annino, Antonio. Silencios y disputas en la historia de Hispanoamérica. Bogotá: Taurus/Universidad Externado de Colombia, 2014·169-174

Francisco A. Ortega, Universidad Nacional de Colombia

Silva, Renán. Lugar de dudas: sobre la práctica del análisis histórico. Breviario de inseguridades. Bogotá: Universidad de los Andes, 2015 · 175-177 Hermes Osorio Cossio, Universidad Nacional de Colombia Eulalia Hernández Ciro, Universidad Nacional de Colombia 

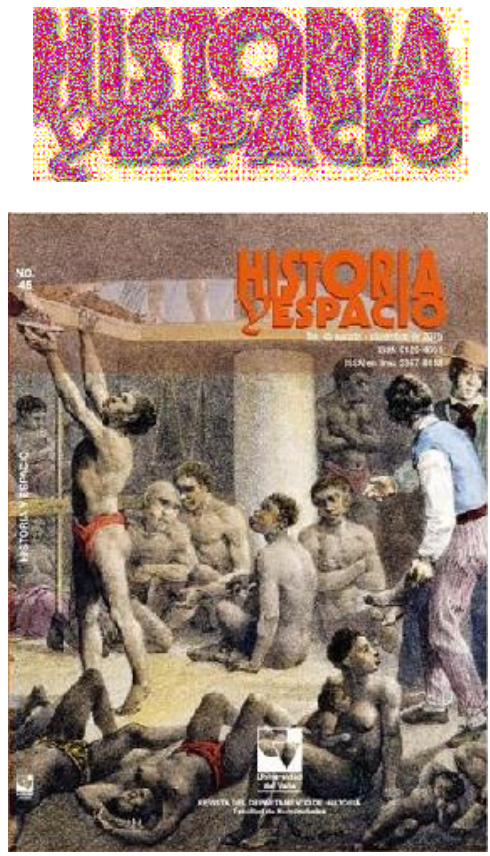

Edición No. 45 Agosto-Diciembre de 2015 ISSN: 0120-4661 (Versión Impresa) ISSN: 2357-6448 (Versión en línea)

Revista Historia y Espacio Facultad de Humanidades Departamento de Historia Edificio: 386, oficina: 1044 Calle 13 \# 100-00, Meléndez e-mail:revistahistoriayespacio@gmail.com Universidad del Valle

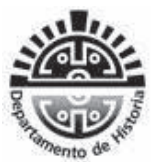

\section{Contenido $\mathrm{No}_{0} .45$}

\section{Artículos}

Los años inciertos del comercio esclavista a los Reinod de Indias: 1640-1680

María Cristina Navarrete P.

La misión franciscana del Yurumanguí

Manuel Serrano García

Los libres de todos los colores en la otra banda del río Cauca Alonso Valencia Llano

La filiación de los reclutas: identidad local, condición social, racialidad y políticas de reclutamiento en la "Provincias del Cauca" (1841-1851)

\section{Luis Ervin Prado Arellano}

Conflictividad, delincuencia y jusicia en el Departamento de Caldas 1900-1925

\section{Edwin Monsalvo Mendoza \\ Miguel Suiarez Aramendiz \\ Davis Herrera Uribe}

Santificados sean los próceres: historia y religiosidad en los centenarios payaneses, 1910-1916

Jaime Aguilar Moreno

\section{Debate}

Francisco José de Caldas: el camino de las ciencias es el camino de la virtud

\section{Luz Marina Duque Martínez}

\section{Reseña}

Earle, Rebecca (2014). España y la independencia de Colombia 1810-1825, Ediciones Facultad de Ciencias Sociales, Universidad de los Andes, Santa fe de Bogotá.

Jorge Isaac Zamudio Franco 
REVISTA HISTORIA Y SOCIEDAD

Departamento de Historia

Facultad de Ciencias Humanas y Económicas

Universidad Nacional de Colombia - Sede Medellín

\section{3 (julio-diciembre de 2017)}

\section{PRESENTACIÓN}

\section{ARTÍCULOS}

Alternativas al saber diplomado en la escena pública: una aproximación al curanderismo a partir de la prensa escrita de las ciudades de Córdoba y de Buenos Aires, Argentina en la década de 1920 MARÍA DOLORES RIVERO, ADRIÁN CARBONETTI, MARÍA LAURA RODRÍGUEZ

Argumentos por la tolerancia religiosa en Colombia, 1832-1853 JOSÉ DAVID CORTÉS GUERRERO

Botánica y topografía: el problema de la nivelación de las plantas en la historiografía científica sobre Francisco José de Caldas MARÍA ALEJANDRA PUERTA OLAYA, JORGE MANUEL ESCOBAR ORTIZ

Una selva de aventuras y misterios: expediciones amazónicas en la literatura brasileña de los años 1920 y 1930 LUCIANA MURARI

Intertextualidad en los textos del antiguo Egipto: un análisis de los "bancos de arena"

LEILA SALEM

El universo burgués tensionado por la honra, la deshonra y la honorabilidad. El caso de Juan Canals, Rosario (Santa Fe-Argentina), segunda mitad del siglo XIX ROMINA GARCILAZO

Geografía, Estado y sociedad en Colombia, 1930-1960.

El proyecto de Geografías Económicas de Colombia de la Contraloría General de la República RENÁN SILVA OLARTE

La "Imago" de Kempis: el discurso barroco como constructor de realidad en la Nueva Granda colonial JUAN PABLO CRUZ MEDINA

"El mismo amor, la misma fe, las mismas lágrimas": iniciativas eclesiales en Ecuador sobre el culto a la Virgen del Quinche en defensa de una República del Sagrado Corazón (1883-1889) LUIS ESTEBAN VIZUETE MARCILLO

Jornada sin Gaitán. Prensa, política y gaitanismo (1948-1953) ADRIANA RODRÍGUEZ FRANCO

\section{RESEÑAS}

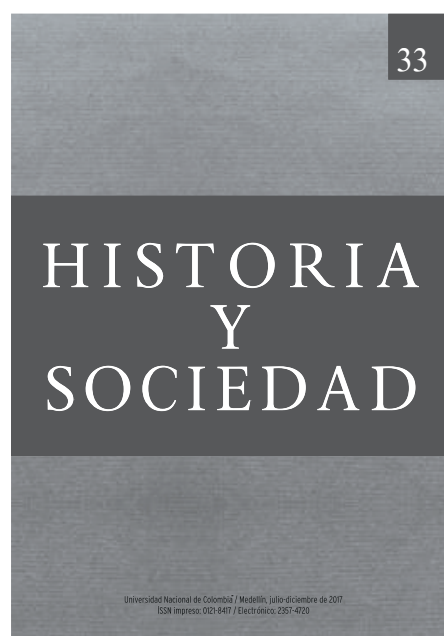

ISSN impreso: 0121-8417

ISSN electrónico: 2357-4720

C O N T A T O Y C A N J E

Autopista Norte Calle 59 A n. ${ }^{\circ} 63$ - 20 Bloque 46 Piso 4 Medellín, Colombia, Sur América

Teléfono: (574) 4309246

Fax: (574) 2604451

E-mail: revhisys_med@unal.edu.co

Página web:

http://www.revistas.unal.edu.co/index.php/hisysoc

\section{S U S C R I P C I Ó N}

Dos ejemplares por año más envío

- Colombia: 50000 COP

- América: 60 USD

- Resto del mundo: 120 USD 


\title{
memoria y sociedad 41
}

\section{Contenido}

\author{
7 Presentación \\ Equipo editorial \\ Dossier \\ 10 La «escuela estallada»: diálogos entre dos \\ nociones de práctica pedagógica \\ Oscar Saldarriaga Vélez \\ 22 \\ Entre la ciencia y el tradicionalismo: una política de la \\ lengua en Colombia desde Michel de Certeau \\ Laura Castiblanco
}
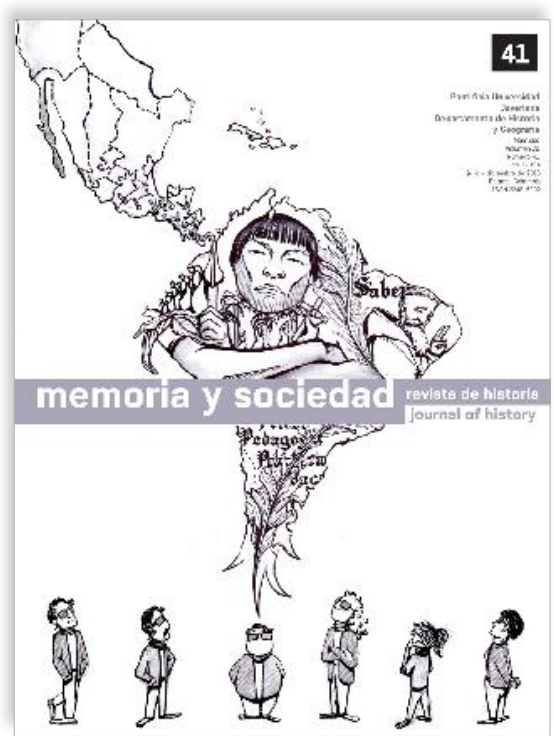

109

Estelas de trayectorias esparcidas: las tácticas indígenas en el contexto de las misiones. Colombia, 1880-1930

Amada Carolina Pérez Benavides

55 Michel de Certeau y las ciencias sociales: un lenguaje alterado Francisco A. Ortega

Temas abiertos

72

Poderes y saberes: una visita guiada sobre el museo y sus visitantes Luz Maceira Ochoa

93

El camino a la especialización espacial: el asentamiento

de la industria de las artes gráficas en el barrio

San Nicolás. Santiago de Cali, 1940-1980

Esteban Morera Aparicio

Ciudadanía, representación política y territorio en la audiencia de Quito: entre el Pacto Solemne de 1812 y el censo poblacional de 1813 Santiago Cabrera Hanna

129

Luchas por el derecho a la salud, el caso del Sindicato Minero de Amagá y Angelópolis, Colombia 1937-1945 Óscar Gallo

Reseñas

145

Laurent, Muriel. Contrabando, poder y color en los albores de la República. Nueva Granada, 1822-1824. Bogotá: Ediciones Uniandes, 2014. 440 pp. Carlos A. Díaz

148 Pérez Benavides, Amada Carolina. Nosotros y los otros. Las representaciones de la nación y sus habitantes, Colombia, 1880-1910. Bogotá: Editorial Pontificia Universidad Javeriana, 2015. 328 pp. Julio Arias Vanegas

153

Mejía de Mesa, Marietta. Entre la mutua dependencia y la mutua independencia. El Hospital San Ignacio y la Facultad de Medicina de la Universidad Javeriana. Bogotá: Universidad Javeriana, 2013. 344 pp. Eduardo Díaz Amado

Scott, Joan. Parité! Equidad de género y la crisis del universalismo francés. México: Fondo de Cultura Económica, 2012. 268 pp. Diana González Rey 


\section{TRASHUMANTE}

REVISTA AMERICANA DE HISTORIA SOCIAL

ISSN: 2322-9381・ ISSN-e:2322-9675• DOI: 10.17533/udea.trahs

\section{Tráfico de esclavos y esclavitud en las Américas. Siglos XVI-XIX}

Alex Borucki

Edgardo Pérez Morales

\section{Investigación}

Aspectos da comunidade islamita negra do Rio de Janeiro no século XIX

José Roberto Góes y Manolo Florentino

Espacios de convivencia y rebeldía. Las cofradías de la población de origen africano en la ciudad de México, siglo XVII

Sandra Nancy Luna García

Formas de alcanzar la libertad en Corrientes, entre manumisiones y patronatos (1800-1850)

Fátima Valenzuela

Revisitar Palmares: histórias de um mocambo do Brasil colonial

Ana Carolina Viotti

Corsarismo y venta de esclavos en Mérida, 1779-1781

Jorge Victoria Ojeda

La trata negrera, sus redes mercantiles portuguesas y estrategias de negocios en Nueva España durante el siglo XVII

Norma Angélica Castillo Palma

Representaciones sobre los esclavizados y descendientes de africanos y la vida nacional argentina: discursos en disputa

Nathalia Guevara Jaramillo

La antigua e incurable enfermedad de María Josefa esclava: claves para el estudio de la salud y enfermedad de esclavas y esclavos en la Capitanía General de Chile, 1756-1823

Tamara Alicia Araya Fuentes

\section{Tema abierto}

Brechas del bienestar: el problema de la vivienda rural argentina entre las décadas de 1930 y 1950

Juan Manuel Cerdá y Alejandra Salomón

\section{Reseñas}

